Carolina Santos Taqueda

\title{
A ETNOECOLOGIA DOS JARDINS-QUINTAL E SEU PAPEL NO SISTEMA AGRÍCOLA DE POPULAÇÕES QUILOMBOLAS DO VALE-DO- RIBEIRA, SÃO PAULO.
}


Carolina Santos Taqueda

\section{A ETNOECOLOGIA DOS JARDINS-QUINTAL E SEU PAPEL NO SISTEMA AGRÍCOLA DE POPULAÇÕES QUILOMBOLAS DO VALE-DO- RIBEIRA, SÃO PAULO.}

Dissertação apresentada ao Departamento de Ecologia do Instituto de Biociências da Universidade de São Paulo, para a obtenção do título de Mestre em Ciências.

São Paulo

2009 
Carolina Santos Taqueda

\title{
A ETNOECOLOGIA DOS JARDINS-QUINTAL E SEU PAPEL NO SISTEMA AGRÍCOLA DE POPULAÇÕES QUILOMBOLAS DO VALE-DO- RIBEIRA, SÃO PAULO.
}

\begin{abstract}
Dissertação apresentada ao Departamento de Ecologia do Instituto de Biociências da Universidade de São Paulo, para a obtenção do título de Mestre em Ciências, na Área de Ecologia.
\end{abstract}

Orientador: Rui Sérgio Sereni Murrieta

São Paulo

2009 


\section{FICHA CATALOGRÁFICA}

\begin{tabular}{|l}
\hline T175e \\
Taqueda, Carolina Santos \\
A Etnoecologia dos jardins-quintal e seu papel \\
no sistema agrícola de populações quilombolas do \\
Vale do Ribeira, São Paulo / Carolina Santos \\
Taqueda. - São Paulo: C. S. T., 2009. \\
213 p. : il. \\
Dissertação (Mestrado) - Instituto de \\
Biociências da Universidade de São Paulo. \\
Departamento de Ecologia. 2009. \\
1. Ecologia Humana 2. Quilombos 3. \\
Agricultura de Coivara 4. Campesinato 5. Mata \\
Atlântica I. Universidade de São Paulo. Instituto de \\
Biociências. Departamento de Ecologia. \\
LC: QH 541.12
\end{tabular}

COMISSÃO JULGADORA

Prof. Doutor(a)

Paulo Inácio de Knegt

López de Prado
Prof. Doutor(a)

Cristina Adams
Prof. Doutor

Rui Sérgio Sereni Murrieta 


\begin{abstract}
À memória de minha tia Eliana, que se foi no meio dessa minha jornada, mas nunca deixou de estar muito perto de mim.
\end{abstract}




\section{AGRADECIMENTOS}

Ao meu orientador, Prof. Dr. Rui Murrieta, pela paciência e compreensão nesses meus primeiros passos como cientista, e por tudo que me ensinou ao longo dessa minha jornada. O aprendizado foi muito além do conteúdo deste trabalho.

Ao Dr. Nelson Novaes Pedroso-Júnior, por possibilitar e acompanhar minhas primeiras idas a campo, e por intermediar meu primeiro contato com o cenário e os atores dessa pesquisa, pelos quais me apaixonei desde a primeira visita.

À Dra. Marie Sugiyama, pela paciência e a ajuda inestimável na identificação botânica.

À Prof. Dra. Cristina Adams, pelas valiosas sugestões profissionais (técnicas e teóricas) e pelo apoio constante.

Ao Prof. Dr. Alexandre Adalardo de Oliveira, pela contribuição, desde a graduação, para a ampliação dos meus conhecimentos acadêmicos e apreciação das ciências naturais, e também pelo auxílio nas análises (e dúvidas) estatísticas deste trabalho.

Ao Prof. Dr. Paulo Inácio Prado, pelo auxílio nas análises estatísticas deste trabalho.

Aos moradores das comunidades quilombolas de Sapatu, Pedro Cubas e São Pedro, por tornarem essa pesquisa possível e prazerosa.

À Fundação de Amparo à Pesquisa de São Paulo (FAPESP), por tornar este trabalho financeiramente viável (processo 06/58624-6).

Aos meus colegas de laboratório, em especial Aglair Pedrosa Ruivo, Natasha Dias Navazinas, Lívia Burgos Lopes, Cauê Dias Carrilho e Helbert Medeiros pelo auxílio direto em campo, e Maissa Salah Bakri, Lúcia Munari, Mirella Abrahão Crevellaro, Vânia Luisa Spressola, e Leandro Gonçalves por estarem sempre dispostos a ajudar dentro e fora do laboratório.

À minha mãe e meu pai, por serem ambos meu esteio em simplesmente tudo na vida, e, como se não bastasse, ainda me auxiliarem diretamente neste trabalho com valiosas sugestões estatísticas e revisões de texto.

Aos meus irmãos, sobrinho, avós e avôs (in memorian), primos, tios (em especial Jorge e José Roberto), tias (em especial Clécia, Eleide, Maria Lúcia, Neida e Stela) e cunhados, por fazerem minha vida valer à pena, sempre.

Às minhas amigas de adolescência Cristiane, Gabriela, Fernanda, Íssis, Laila, Lia, Lúcia, Mahyra e Sandra, por me acompanharem de perto nos momentos mais importantes da vida, tornando tudo mais fácil e mais divertido. 
Às minhas amigas de faculdade Camila, Ilana, Maissa, Nina ,Talita, por persistirem desde o primeiro dia de faculdade como amigas verdadeiras, e Fernanda e Flávia, por aumentarem essa turma.

Aos professores e funcionários do Instituto de Biociências da Universidade de São Paulo, pelos auxílios diversos que possibilitaram o andamento desta pesquisa. 


\section{SUMÁRIO}

INDICE DE FIGURAS

INDICE DE TABELAS

CAPÍTULO 1 - INTRODUÇÃO

1.1 Motivação e Justificativa 1

$\begin{array}{ll}1.2 \text { Objetivos } & 5\end{array}$

1.2.1 Objetivo Geral

1.2.2 Objetivos Específicos 5

$\begin{array}{ll}1.3 \text { Estrutura da Dissertação } & 6\end{array}$

CAPÍTULO 2 - CONTEXTUALIZAÇÃO

2.1 Bases teóricas: Antropologia Ecológica e Etnoecologia 8

$\begin{array}{ll}2.2 \text { O Campesinato latino-americano } & 15\end{array}$

2.3 Os sistemas agrícolas tropicais baseados na coivara 23

$\begin{array}{ll}2.4 \text { Caracterização preliminar dos jardins-quintal } & 27\end{array}$

CAPÍTULO 3 - MATERIAL MÉTODOS 35

3.1 Vale do Ribeira: a ocupação humana e os caipiras negros paulistas 35

3.2 Vale do Ribeira: a Floresta Tropical Atlântica 45

$\begin{array}{ll}3.3 \text { As comunidades quilombolas } & 48\end{array}$ 
$\begin{array}{ll}\text { 3.3.1 Histórico } & 49\end{array}$

$\begin{array}{lr}\text { 3.3.1.1 Sapatu } & 49\end{array}$

3.3.1.2 São Pedro $\quad 50$

3.3.1.2 Pedro Cubas $\quad 52$

3.3.2 Aspectos demográficos e socioeconômicos 53

3.4 Metodologia de pesquisa 58

3.4.1 Embasamento teórico-metodológico 58

3.4.2 Coleta de dados $\quad 59$

$\begin{array}{ll}\text { 3.4.3 Análise dos dados } & 61\end{array}$

3.4.3.1 Análise estatística de dados 62

CAPÍTULO 4 - RESULTADOS $\quad 65$

4.1 Composição florística 65

4.2 Estrutura dos jardins-quintal 76

4.2.1 Estratos verticais: os hábitos de vida vegetal 76

$\begin{array}{ll}\text { 4.2.2 As zonas de cultivo } & 80\end{array}$

4.4 As múltiplas funções do jardim-quintal

4.5 Manejo: plantio, cultivo, manutenção e trocas 91

4.6 Criação de animais 99

4.7 Transformações históricas no espaço e na composição florística 106

4.8 A relação entre as variedades de roça e os jardins- quintal 111

4.9 Transformações sócio-econômicas e os jardins-quintal 113

CAPÍTULO 5 - DISCUSSÃO E CONCLUSÕES 125

5.1 Complexidade estrutural e composição florística 125 
5.2 Multifuncionalidade: transformação e diferenciação

5.3 Jardim-quintal: a parte feminina da agricultura

5.5 Diferenças socioeconômicas entre as unidades domésticas 


\section{LISTA DE FIGURAS}

Figura Pág.

Figura 3.1: localização das 9 comunidades do Médio Ribeira visitadas previamente para a realização deste estudo (limites municipais de Eldorado e lporanga - SP)

Figura 3.2: Alguns aspectos demográficos das comunidades quilombolas de Pedro Cubas, São Pedro e Sapatu.

Figura 3.3: principais profissões dos chefes de família nas comunidades

Figura 3.4: principais fontes de renda famílias das comunidades quilombolas de Sapatu, Pedro Cubas e São Pedro (Fonte Pedroso-Júnior 2008)

Figura 4.1: teste de normalidade de Anderson Darling relativo à diversidade de etnovariedades por jardim-quintal considerando as comunidades de Sapatu, Pedro Cubas e São Pedro $(n=71)$

Figura 4.2: teste de Igualdade de Variâncias diversidade de etnovariedades por jardim-quintal entre as comunidades quilombolas de Sapatu e Pedro Cubas

Figura 4.3: teste de Igualdade de Variâncias diversidade etnovariedades por jardim-quintal entre as comunidades quilombolas de São Pedro e Pedro Cubas

Figura 4.4: teste de Igualdade de Variâncias diversidade de etnovariedades por jardim-quintal entre as comunidades quilombolas de São Pedro e Sapatu

Figura 4.5: Análise de Variância para uma variável (One-Way ANOVA) para diversidade de etnovariedades por jardim-quintal nas comunidades quilombolas de Sapatu, Pedro Cubas e São Pedro.

Figura 4.6: familiaridade dos informantes com as etnovariedades cultivadas em seus jardins-quintal das comunidades quilombolas de Sapatu, Pedro Cubas e São Pedro (antigas: há mais de 40 anos na comunidade; recentes: há menos de 40 anos).

Figura 4.7: famílias biológicas que tiveram maior abundância numérica de 72 etnovariedades nos jardins-quintal da comunidade quilombola de Sapatu. 
Figura 4.8: famílias biológicas que tiveram maior abundância numérica de etnovariedades nos jardins-quintal da comunidade quilombola de Pedro Cubas.

Figura 4.9: famílias biológicas que tiveram maior abundância numérica de 73 etnovariedades nos jardins-quintal da comunidade quilombola de São Pedro.

Figura 4.10: famílias biológicas que tiveram maior abundância numérica de 73 etnovariedades nos jardins-quintal para total geral entre as comunidades quilombolas de Sapatu, Pedro Cubas e São Pedro.

Figura 4.11: famílias biológicas com maior diversidade de etnovariedades nos jardins-quintal da comunidade quilombola de Sapatu.

Figura 4.12: famílias biológicas com maior diversidade de etnovariedades nos jardins-quintal da comunidade quilombola de Pedro Cubas.

Figura 4.13: famílias biológicas com maior diversidade nos jardins-quintal da 75 comunidade quilombola de São Pedro.

Figura 4.14: famílias biológicas com maior diversidade nos jardins-quintal para 75 total geral entre as comunidades quilombolas de Sapatu, Pedro Cubas e São Pedro.

Figura 4.15: panorama geral de alguns jardins-quintal, revelando os principais estratos verticais da vegetação

Figura 4.16: proporções que cada estrato ocupa nos jardins-quintal das três 78 comunidades quilombolas estudadas (Sapatu, Pedro Cubas e São Pedro), e abundância numérica total (considerando repetições) de etnovariedades para cada um dos estratos.

Figura 4.17: esquema da configuração espacial geral dos jardins-quintal das comunidades quilombolas de São Pedro e Pedro Cubas.

Figura 4.18: esquema da configuração espacial geral dos jardins-quintal da comunidade quilombola de Sapatu.

Figura 4.19: alguns dos múltiplos usos de etnovariedades cultivadas nos jardins quintal das comunidades quilombolas de Sapatu, Pedro Cubas e São Pedro.

Figura 4.20: categorias de uso que congregam maior abundância de etnovariedades cultivadas no espaço dos jardins-quintal para as comunidades 
de Sapatu, Pedro Cubas e São Pedro

Figura 4.21: principais responsáveis pelo plantio de etnovariedades nos jardinsquintal das comunidades quilombolas Sapatu, Pedro Cubas e São Pedro.

Figura 4.22: auxílios alternativos à ajuda do cônjuge para o manejo dos jardinsquintal nas comunidades quilombolas de Sapatu, Pedro Cubas e São Pedro.

Figura 4.23: principais procedências de sementes e mudas das etnovariedades cultivadas nos jardins-quintal das comunidades quilombolas de Sapatu, Pedro Cubas e São Pedro.

Figura 4.24: principais problemas enfrentados para o cultivo no espaço dos jardins-quintal das comunidades quilombolas de Sapatu, Pedro Cubas e São Pedro.

Figura 4.25: principais animais criados no espaço dos jardins-quintal das comunidades quilombolas de Sapatu, Pedro Cubas e São Pedro

Figura 4.26: ocorrência dos animais criados nos espaços dos jardins-quintal das comunidades quilombolas de Sapatu, São Pedro e Pedro Cubas.

102

Figura 4.27: abundância numérica dos animais criados no espaço dos jardinsquintal nas comunidades quilombolas de Sapatu, São Pedro e Pedro Cubas.

Figura 4.28: contagem de etnovariedades cultivadas nos espaços dos jardinsquintal e que estavam presentes ou ausentes no espaço destinado ao cultivo de roça, nas comunidades quilombolas de Sapatu, São Pedro e Pedro Cubas.

Figura 4.29: dendograma baseado no número de eletrodomésticos e nível de 115 escolaridade do chefe de família $(n=71)$, estruturado pelo método de análise de agrupamento hierárquico. Algoritmo de agrupamento: Distância Euclidiana Padronizada. Método de aglomeração: média aritmética não ponderada (UPGMA).

Figura 4.30: dendograma baseado no número de eletrodomésticos e nível de escolaridade do chefe de família $(n=71)$, estruturado pelo método de análise de agrupamento hierárquico. Algoritmo de agrupamento: Distância Euclidiana Padronizada. Método de aglomeração: média aritmética não ponderada (UPGMA).

Figura 4.31: gráfico de dispersão relacionando diversidade de etnovariedades por unidade de jardim-quintal em função da classificação socioeconômica gerada pelo método de agrupamento hierárquico sem a inclusão do fator 
"liderança"

Figura 4.32: gráfico de dispersão relacionando diversidade de etnovariedades por unidade de jardim-quintal em função da classificação socioeconômica gerada pelo método de agrupamento hierárquico com a inclusão do fator "liderança" 


\section{LISTA DE TABELAS}

Tabela

Pág.

Tabela 3.1: Alguns aspectos demográficos das comunidades quilombolas de Pedro Cubas, São Pedro e Sapatu.

Tabela 4.1: caracterização florística dos jardins-quintal das comunidades quilombolas de Sapatu, Pedro Cubas e São Pedro

Tabela 4.2: teste não-paramétrico de Kruskal-Wallis para comparação de medianas das contagens relativas as etnovariedades antigas e recentes.

Tabela 4.3: Tabela 4.3: teste não paramétrico de Kruskal-Wallis para etnovariedades distribuídas nos diferentes estratos verticais da vegetação dos jardins-quintal.

Tabela 4.4: teste não paramétrico de Kruskal-Wallis para etnovariedades distribuídas nas diferentes categorias de uso da vegetação dos jardins-quintal

Tabela 4.4: teste não paramétrico de Kruskal-Wallis para responsável pelo plantio de etnovariedades.

Tabela 4.5: teste não paramétrico de comparação de medianas (Kruskal-Wallis) das contagens relativas às principais categorias de procedência de sementes e mudas das etnovariedades cultivadas nos jardins-quintal.

Tabela 4.6: teste não paramétrico de comparação de medianas (Kruskal-Wallis) das contagens relativas aos animais mais criados no espaço nos jardinsquintal.

Tabela 4.7: teste não paramétrico de comparação de medianas (Kruskal-Wallis) das contagens relativas às etnovariedades cultivadas simultaneamente no espaço nos jardins-quintal e nas roças.

Tabela 4.8: índices equivalentes ao número de eletrodomésticos e nível de escolaridade por unidade doméstica.

Tabela 4.9: índices equivalentes ao número de eletrodomésticos, nível de escolaridade e liderança por unidade doméstica. 


\section{CAPÍTULO I \\ INTRODUÇÃO}

\subsection{Motivação e Justificativa}

Os sistemas agrícolas tradicionais constituem uma das principais fontes de subsistência para populações pobres rurais que habitam as florestas tropicais ao redor mundo. De maneira geral, esses sistemas produtivos baseiam-se criticamente na mão de obra familiar e, portanto, são altamente influenciados pela organização social e dinâmica da unidade doméstica ${ }^{1}$ (Ali 2005, Pedroso-Júnior 2008, PedrosoJúnior et al 2008). Paralelamente, o que se observa é que as práticas agrícolas de subsistência dessas populações vêm passando por crescentes transformações, resultantes principalmente da sua inclusão gradativa na economia de mercado, da expansão das fronteiras urbanas em direção às fronteiras agrícolas, do aumento da densidade populacional, e da limitação do uso de recursos naturais imposta por leis de proteção e conservação do meio ambiente (Kulikoff 1993, Angelsen 1995, Byron e Arnold 1999, Cardoso et al 2001, Bray et al 2003, Metzger 2003, Kumar e Nair 2004, McSweeney 2005, Pedroso-Júnior 2008, Pedroso-Júnior et al 2008). Essas mudanças geralmente resultam em reestruturações do trabalho familiar voltado para o cultivo e em mudanças estruturais e funcionais da paisagem natural, já que esta é altamente influenciada pelas técnicas e práticas de cultivo das populações que vivem em estreita relação com o ambiente "natural". As mudanças na paisagem podem ocorrer, por exemplo, através da diminuição dos ciclos de cultivo, da diminuição das áreas de roça, e/ou da introdução de cultivares perenes objetivando predominantemente a comercialização (Kulikoff 1993, Byron e Arnold 1999, Bray et al 2003, Metzger 2003, Kumar e Nair 2004, McSweeney 2005).

\footnotetext{
${ }^{1}$ No âmbito dessa dissertação, a unidade doméstica (UD) é o núcleo produtivo da agricultura familiar nos trópicos, uma categoria sócio-espacial onde as relações familiares e produtivas articulam-se em torno da referencia geográfica da casa. Sabe-se que as unidades domésticas podem ser constituídas por mais de uma unidade familiar. Ou seja, o espaço físico da residência (unidade doméstica) pode conter mais de uma família nuclear (unidade familiar), que geralmente é composta por um casal e seus filhos ou por um dos cônjuges e seus filhos (Pedroso-Júnior et al 2008b).
} 
Dessa rede de interações entre a organização social e econômica das comunidades rurais dos trópicos e o ecossistema no qual estão inseridas, surge o importante paradoxo constituído pela necessidade de preservação do meio "natural" e a manutenção (ou melhoria) da qualidade de vida humana. Esse panorama se intensificou especialmente a partir da década de 60, quando o interesse social, em torno dos problemas relacionados ao ambiente natural, se consolidou mundialmente (Banerjee, 2003). A diminuição massiva da biodiversidade resultantes da crescente intensificação da exploração dos recursos naturais, do surgimento de novas tecnologias agrícolas, do aumento da pressão populacional e das mudanças nas relações de produção, vem sendo apontada por muitos como elemento central de um provável colapso dos sistemas político e socioeconômico vigentes. $O$ desenvolvimento dessas questões ocasionou a ampliação de pesquisas na área de Conservação Biológica e a expansão dos ecossistemas protegidos através da implantação de Unidades de Conservação (Carvalho, 2006; Hanazaki 2001; Orlove e Brush 1996). Por outro lado, muitas das áreas destinadas a preservação parcial ou estrita já possuíam em, seus domínios, diversos grupamentos humanos que dependem criticamente do ambiente natural para sua subsistência.

Como forma de compreender as implicações desse cenário paradoxal, tanto para as populações campesinas quanto para os ambientes naturais em que habitam, diversos estudos vêm sendo dedicados à compreensão das relações de produção, das práticas culturais, da organização e dinâmica social envolvidas nos sistemas de subsistência camponês. De maneira geral, os campesinos seriam um setor social composto por produtores agrícolas com efetivo controle da terra, mas que consideram a atividade agrícola apenas como um meio de vida e não como um negócio visando lucro (Cancian, 1989; Pereira de Queiroz, 1973; Wolf, 1955). São populações pobres tanto em sentido absoluto quanto em relação a muitos nãocampesinos, sendo também subjugados política e economicamente (Cancian, 1989; Pereira de Queiroz, 1973; Wolf, 1955). Diferem das minorias étnicas urbanas porque são rurais e usualmente produzem uma porção significativa de sua alimentação (Cancian, 1989). Nas regiões tropicais, o sistema agrícola camponês é largamente baseado na itinerância das áreas destinadas ao cultivo (roças), sendo esse o elemento chave dos sistemas produtivos das populações rurais mais antigas e fator primordial das alterações na dinâmica da paisagem florestal habitada por humanos 
(Metzger, 2003). Por essa razão, o enfoque dos estudos acadêmicos que envolvem os sistemas agrícolas tradicionais trata principalmente da dinâmica das roças (Albuquerque et al., 2005; Altieri, 1999; Altieri et al., 1987; Angelsen, 1995; BarreraBassols e Toledo, 2005; Begossi et al., 2000; Boserup, 1987; Cardoso et al., 2001; Conklin, 1961; Fernandes e Nair, 1986; Fujisaka et al., 2000; Griffith, 2000; Hazanaki, 2001; Metzger, 2003; Pedroso-Júnior, 2008; Pedroso-Júnior et al., 2008b; Soewarwoto et al., 1985). O sistema agrícola itinerante praticado pelos campesinos e indígenas em regiões tropicais, geralmente envolve o corte e a queima da vegetação na estação seca e a utilização das cinzas produzidas, como nutrientes para o desenvolvimento da plantação no início da estação chuvosa (Angelsen, 1995; Boserup, 1987; Conklin, 1961; Dean, 1996; Metzger, 2003; Pedroso-Júnior, 2008a; Pedroso-Júnior et al., 2008b). O declínio da fertilidade do solo, e o aumento dos problemas de ervas daninhas, levam os agricultores a abandonarem os campos após poucos anos de cultivo (Angelsen, 1995; Boserup, 1987; Conklin, 1961; Dean, 1996; Metzger, 2003; Pedroso-Júnior, 2008a; Pedroso-Júnior et al., 2008b). Outros tipos de vegetação dominam, então, essa paisagem, sendo que a mesma eventualmente se regenera em floresta secundária antes que o ciclo se repita (Angelsen, 1995; Boserup, 1987; Conklin, 1961; Dean, 1996; Metzger, 2003; Pedroso-Júnior, 2008a; Pedroso-Júnior et al., 2008b). Esse período de descanso (ou repouso) varia de 5 a 30 anos. (Angelsen, 1995; Boserup, 1987; Conklin, 1961; Dean, 1996; Metzger, 2003; Pedroso-Júnior, 2008a; Pedroso-Júnior et al., 2008b). Por essa configuração geral, o tipo de sistema agrícola descrito é amplamente conhecido como agricultura de corte-e-queima (ou coivara), uma prática realizada em diversas regiões tropicais em todo o mundo desde o neolítico (Dean, 1996; Harris, 1972; Kleinman et al., 1995; Mithen, 2003; Pedroso-Junior et al., 2008).

Esse panorama geral, no entanto, vem sofrendo profundas transformações decorrentes das diversas estratégias que pequenos produtores locais vêm desenvolvendo para se adaptar às constantes mudanças ecológicas e políticoeconômicas que vêm ocorrendo no Vale do Ribeira. De maneira geral, estão partindo de uma agricultura familiar (de baixo impacto, com longos períodos de pousio e alta diversidade intra e interespecífica), baseada em técnicas agrícolas tradicionais, para formas intensivas de cultivo, dependentes de insumos (com curtos períodos de pousio e baixa diversidade de cultivos) e a adoção de cultivares 
altamente produtivos e com alta aceitação no mercado em detrimento de espécies e etnovariedades indígenas e selvagens ${ }^{2}$ (Ali, 2005). Alguns habitantes estão simplesmente abandonando as atividades agrícolas em busca de outras alternativas de trabalho em centros urbanos próximos ou até mesmo em cidades maiores onde possuem parentes e migrantes já estabelecidos (Pedroso-Júnior, 2008).

Outra forte tendência da reorganização do sistema produtivo desses grupos frente às mudanças sociais, econômicas e políticas que enfrentam é o cultivo em áreas cada vez mais próximas ao complexo residencial (Cerda e Mukul, 2008; Fairhead e Leach, 1995). Nesse contexto, a unidade formada pelos jardins e quintais, até então considerados secundários na produção e reprodução doméstica, constituem um importante elo no entendimento das transformações que vêm ocorrendo nos referidos sistemas agrícolas. Por depender da mão de obra predominantemente familiar, espera-se que o design, organização e manejo dos jardins e quintais sejam altamente influenciados por fatores relativos à dinâmica interna da unidade doméstica (Cerda e Mukul, 2008). A estrutura e organização familiar voltada para trabalho agrícola, por sua vez, é significativamente sensível às mudanças e pressões externas discutidas anteriormente, de maneira que, em uma rede de relações, a diversidade florística e a estrutura dos jardins e quintais atuariam como indicadores de parte importante das alterações que os sistemas produtivos dos campesinos vêm sofrendo.

Em vista disso, este estudo investiga diversos aspectos referentes aos jardins e quintais das comunidades quilombolas de Sapatu, Pedro Cubas e São Pedro, município de Eldorado Paulista, São Paulo, como forma de compreender e problematizar a importância desses espaços no sistema produtivo agrícola mais abrangente desses caipiras negros, bem como as transformações pelas quais essas mesmas subunidades agrícolas vêm passando ao longo das últimas décadas. Sendo assim, (e por meio da elaboração das etapas mencionadas no fim deste capítulo) esta dissertação pretende responder algumas questões pertinentes aos temas anteriormente propostos:

\footnotetext{
2 Neste trabalho são consideradas "etnovariedades" as plantas reconhecidas e nomeadas pela população local, possuindo uso característico entre as famílias. As etnovariedades distinguem-se não apenas pela denominação que lhes é atribuída, mas também por sua função e aspecto morfológico que apresentam.
} 
1. Quais aspectos da estrutura e função das áreas de cultivo próximos ou adjacentes ao complexo residencial (jardins e quintais) das comunidades estudadas estão se transformando diante das mudanças na organização social e econômica que estas populações vêm sofrendo nas últimas décadas?

a. Quais os principais fatores que ocasionam as transformações nos jardins e quintais?

b. Qual a relação entre as alterações nos jardins e quintais e as que vêm ocorrendo com o sistema agrícola local como um todo?

2. A heterogeneidade econômica e social entre as unidades domésticas das comunidades estudadas estão relacionadas à diversidade de etnovariedades cultivadas nos espaços referentes aos jardins e quintais?

\subsection{Objetivos}

\subsubsection{Objetivo geral}

O presente estudo pretendeu, em linhas gerais, avaliar o papel e as transformações estruturais e funcionais (principalmente das últimas décadas) das áreas de cultivo próximas ao complexo residencial (como os jardins e quintais) nos sistemas agrícolas itinerantes de algumas comunidades rurais negras (caipiras negros) da região do Vale do Rio Ribeira de Iguape, sudeste do Estado do São Paulo.

\subsubsection{Objetivos específicos}

a. Descrever e analisar a composição botânica dos jardins e quintais e sua diversidade inter e intraespecífica; 
b. Descrever e caracterizar as práticas agrícolas nos jardins e quintais;

c. Descrever e analisar os usos e função dos jardins e quintais;

d. Descrever e analisar os processos de formação histórica e social do complexo jardim quintais;

\subsection{Estrutura da dissertação}

Para cumprir os objetivos propostos, o presente trabalho compreende cinco capítulos principais. $\mathrm{O}$ primeiro deles discute brevemente o cenário no qual se coloca a questão central e as bases teóricas que foram utilizadas como orientação fundamental desta pesquisa. No segundo capítulo são descritas as unidades principais da paisagem agrícola dos quilombos do Médio Ribeira e os atores que transformam (e que se transformam) nessa paisagem. Este mesmo capítulo contempla, ainda, as descrição da metodologia de pesquisa e do tratamento estatístico de parte dos dados coletados. O quarto capítulo trata dos resultados obtidos no estudo, e divide-se em seis etapas principais de descrição, análise e caracterização. A primeira delas refere-se à composição botânica dos jardins e quintais, dentro de contexto histórico-agrícola das comunidades estudadas. Posteriormente, são analisados e descritos os aspectos estruturais desses espaços, referentes tanto aos seus componentes verticais (principais estratos vegetais) quanto aos horizontais (zonas distinguidas pelas diferenças de manejo, cultivo e função). A terceira etapa diz respeito às múltiplas funções dos jardins e quintais, relacionadas principalmente à alta diversidade de função de cultivo das variedades vegetais e a produção de proteína animal. Em um quarto momento são descritas e caracterizadas as práticas agrícolas (plantio, cultivo, manutenção e trocas), bem como as dificuldades enfrentadas na unidade de produção. No momento seguinte são analisadas questões relativas à dinâmica interna da unidade doméstica (UD), considerando a relação da organização e estrutura da UD com alguns aspectos estruturais e de composição dos jardins e quintais anteriormente trabalhados no estudo. Posteriormente, é realizada uma pequena descrição e análise dos processos de formação histórica e social do complexo formado pelos jardins e quintais, que 
resultaram em transformações significativas no espaço e na composição botânica desses subsistemas nas últimas décadas. Na sexta e última (mas não menos importante) etapa, são considerados os fatores sociais e econômicos mais abrangentes das comunidades estudadas, partindo-se para uma análise da relação entre algumas destas variáveis com parte do conjunto de dados referentes à composição florística dos jardins e quintais. O quinto capítulo discute o cenário proposto pelos resultados encontrados, e propõe as principais conclusões gerais do trabalho. 


\section{CAPÍTULO 2 \\ CONTEXTUALIZAÇÃO}

\subsection{Bases teóricas: Antropologia Ecológica e Etnoecologia}

Questões que se posicionam entre as ciências sociais e a ecologia não são novidade para a Antropologia. O comportamento humano há muito se mostrou indissociável do ambiente natural no qual o homem está inserido, assim como as formas de organização social, política e econômica que se desenvolvem a partir dele (Descola e Palsson, 1996; Escobar, 1999; Viveiros de Castro, 2002). No entanto, articular como, historicamente, a humanidade incorporou o meio biofísico, levandose em consideração os modos de percepção e experiências particulares de cada população, sempre foi um desafio particular para a Antropologia (Escobar, 1999). Uma compreensão cada vez mais clara dessa relação entre o homem e o ambiente natural vem ao longo da história ampliando conceitos antropológicos e ecológicos, principalmente no sentido de incluir a atividade política dentro de uma análise ecossistêmica em grande parte socialmente construída (Greenberg e Park, 1994).

Sob uma perspectiva histórica, a relação entre o homem e o ambiente natural é relatada desde o início da civilização (Diamond, 2003; Mithen, 2001; Ribeiro, 1996). A apropriação humana da "natureza" através da utilização de uma gama imensa de vegetais certamente vêm ocorrendo mesmo antes desse processo ser reportado historicamente. Em princípio este contato buscava suprir as necessidades mais básicas, como a alimentação, obtenção de materiais para construção de habitações, ferramentas e utensílios, através da extração e coleta dos vegetais. Aos poucos, com a prática da agricultura e a descoberta de possíveis aplicações terapêuticas de algumas espécies de planta, este relacionamento foi ampliado (Diamond, 2003; Mithen, 2001; Ribeiro, 1996). No entanto, foi o encontro de mundos e de ecologias proporcionado (em grande escala) pela conquista das Américas que gerou a necessidade crítica de se desenvolver um método analítico que, posteriormente, seria a base da Antropologia (Eriksen e Nielsen, 2007). Nesse período, o grande desafio do desenvolvimento político e econômico era a transposição ecológica, ou seja, entender como os povos conquistados conseguiam 
dominar seu ambiente (Crosby, 1993; Dean, 1991). Desde então, foi crescente o interesse em entender o "outro" cultural e ambiental, ou melhor, em ampliar e compreender de maneira mais clara a interface entre a ecologia e sociedade humana (Sutton 2004).

Apesar de importantes contribuições desde os anos 600 até o século XVIII, as pesquisas de caráter antropológico (relatos e a crescente experiência com o outro) constituíram uma disciplina científica apenas quando se integraram com um corpos teóricos no século XIX (Eriksen e Nielsen, 2007). Foi somente após a Primeira Guerra Mundial, no entanto, que a Antropologia definiu-se como a disciplina acadêmica que conhecemos atualmente. Suas bases mais fortes partiram de quatro países ocidentais: França, Grã-Bretanha, Estados Unidos e Alemanha (Boas, 2004; Dumont, 1985; Durkheim e Mauss, 1903; Evans-Prichard, 1978; Malinowsky, 1975; Malinowsky, 1984; Mauss, 1909a e 1909b; Mauss e Hubert, 1902-3; RadcliffeBrown, 1989). A expansão e institucionalização da Antropologia ocorreram principalmente após a II Guerra Mundial. Entre meados da década de 40 e a década de 60 (quando sérias transformações políticas e culturais ocorriam em todo o mundo), a disciplina sofreu importantes mudanças, referentes essencialmente à reconceitualização da economia e política e ao surgimento de "novas teorias de significado simbólico" (Eriksen e Nielsen, 2007, p.117). A partir da década de 60 a investigação antropológica consolida-se sobre dois eixos principais: o materialismo (que entendia as bases materiais como fator principal de influência, condicionamento, e determinação das outras dimensões do sistema sociocultural) e o ideacionismo (que entendia que as formas de organização social e as formas de expressão simbólica têm vida própria) (Diamond, 2003; Steward, 1955; White 2006).

Dentro desse cenário surge a sub-disciplina conhecida como Antropologia Ecológica. Pode-se dizer que essa área do conhecimento antropológico tem persistido e se expandido por seis décadas (desde os primeiros dias da Ecologia Cultural até a moderna Antropologia Ambiental). Neste trabalho se define Antropologia Ecológica como "o estudo das relações entre a dinâmica populacional, a organização social e a cultura das sociedades humanas e o meio ambiente nos quais elas estão inseridas" (Neves, 1996, p.18). Trata-se de um exame predominantemente materialista das sociedades humanas, com bastante afinidade com outros campos de estudo, como as Ciências Biológicas e o Marxismo Estrutural 
(Neves, 1996). O desenvolvimento da Antropologia Ecológica é geralmente dividida em três estágios, que possuem entre si uma grande relação de reatividade. $O$ primeiro estágio situa-se entre início da década de 40 e início da década 60, tendo como principais autores relacionados Julian Sterward e Leslie White. De maneira geral, trata-se de um período de retomada de evolucionismo na Antropologia, sendo o ambiente considerado como fator gerador do processo cultural (Neves, 1996). A ecologia cultural de Steward (1955) sugere que os recursos críticos relativos à alimentação (ambiente efetivo), e a maneira como esses recursos eram explorados pelas populações locais (sistema de subsistência) motivariam comportamentos e formas de organização sociais específicas (núcleo cultural). Dessa conceituação geral depreendem-se as idéias de resposta adaptativa local e multilinearidade (não haveria nem uma direção única nem uma causa única para as repostas adaptativas locais) (Steward, 1955).

A visão de Leslie White $(1943,2006)$ por sua vez, pode ser denominada materialismo evolutivo ou evolucionismo materialista (White, 1943; Dawson, 2002; White, 2006; Eriksen e Nielsen, 2007). Com uma retomada corajosa do pensamento evolucionista na Antropologia, White propunha, dentro de uma visão conhecida como "determinismo tecnológico", que a energia e a tecnologia seriam por si só os aspectos mais determinantes na explicação da complexificação social humana (Eriksen e Nielsen, 2007; Neves, 1996; White, 1943; White, 2006;). Sem se ater aos "processos locais de adaptação cultural" ou o "destino histórico evolutivo das sociedades em particular", White $(1943,2006)$ dirigia seus estudos para história humana universal (Neves, 1996, p. 26; White, 1943 e 2006). Desse modo, a base para compreensão das variações na forma dos sistemas sociais humanos seria a tecnologia, ou melhor, as formas de captura, transformação e aplicação da energia livre que cada sociedade dispunha e propunha. Juntas, a estrutura social e a tecnologia determinariam o conteúdo e orientação ideológica da sociedade humana, sendo a quantidade de energia livre disponível no ambiente o único fator limitante para a "evolução cultural" (Neves, 1996, p. 28). Dessa forma, as sociedades teriam uma ligação estreita com seu entorno ecológico, diferindo da idéia de sociedade como uma entidade autônoma com sua própria dinâmica auto-suficiente (Rappaport, 1971). 
As correntes antropológicas que caracterizaram o segundo estágio da Antropologia Ecológica ganharam força durante a década de 60 e prevaleceram até início da década de 80 . Nesse período, duas correntes principais tiveram destaque: o neo-evolucionismo e os neo-funcionalismo. A primeira delas significou, essencialmente, a ponte entre o evolucionismo universal de White, e o adaptativismo local de Steward (Neves, 1996). Pode-se considerar, portanto, que a principal contribuição para a sub-disciplina veio da segunda vertente, a dos neofuncionalistas, que de fato inovaram ao incorporarem o conceito de ecossistema como unidade funcional mais inclusiva (Moran, 1991; Neves, 1996). A nova unidade de análise passou a ser a população local, sendo a cultura considerada uma propriedade do objeto de análise - com importante papel no sistema adaptativo (Neves, 1996). Nesse momento, "o estudo das bases materiais de sustentação das sociedades humanas (e seus mecanismos de regulação) é trazido para dentro do quadro teórico-metodológico da Ecologia Biológica" e essa vertente da Antropologia Ecológica passa a ser conhecida também como Ecologia Humana (Neves, 1996, p.39). A Ecologia Humana (que assume a comunidade como unidade de análise, de maneira similar às demais Ecologias) pode ser definida como o estudo das interações entre as populações humanas, o ambiente (físico e/ou sócio-político), e os fatores que afetam tal relação. (Begossi, 1993; Neves, 1996). A principal limitação da perspectiva neo-funcionalista foi a de lançar mão do conceito biológico de ecossistema em voga - de maneira integral - como forma de compreender essa rede de influencias. Ou seja, os sistemas sócio-culturais (e sua relação com o ambiente biofísico) passam a ser entendidos como sistemas cibernéticos, fechados, autoregulados e que tendem invariavelmente ao equilíbrio (Rappaport, 1971). Dessa forma, tornava-se comum desconsiderar, da análise, aspectos como as tomadas de decisão individuais, a história e mudanças estruturais das comunidades humanas associadas, bem como outras influências externas e internas que o sistema poderia sofrer (Kottack, 2006; McCabe, 2004; Moran, 1991; Neves, 1996; Orlove, 1980). De maneira mais abrangente, as críticas a esse tipo de enfoque pontuavam os aspectos reducionista e funcionalista do mesmo (ênfase em estratégias adaptativas e eficiência energética). A escala de análise também se tornou um dos principais desafios para a abordagem em discussão, já que as fronteiras da influência humana não são facilmente delimitadas (Kottack, 2006; McCabe, 2004; Moran, 1991; Neves, 
1996; Orlove, 1980). Tornou-se difícil mensurar a abrangência regional e global dentro dessas relações, considerando o alcance e a capacidade das políticas globais, do fluxo de informações, e de demais agentes externos do mundo moderno (Kottack, 2006; McCabe, 2004; Moran, 1991; Neves, 1996; Orlove, 1980).

Com as críticas ao modelo de equilíbrio homeostático, há o enfraquecimento do conceito de ecossistema como unidade funcional dentro das pesquisas realizadas no campo da Antropologia Ecológica (Neves, 1996). A visão essencialista de um ambiente homogêneo, estático e previsível passa a ser encarada como uma idéia bastante simplista e artificial, e, por essa razão, tende a ser aos poucos substituída pela de um ambiente dinâmico, instável, heterogêneo e pouco previsível (Dove, 2001; Kottak, 2006; McCabe, 2004; Neves, 1996; Orlove, 1980). Essa visão anti-essencialista ganha força principalmente a partir da década de 80 , momento em que a sub-disciplina em discussão passa por uma nova resignificação de seu programa de pesquisa e entra em seu terceiro estágio de desenvolvimento. $O$ enfoque dessa nova fase é centrado no distúrbio, na casualidade, e na desordem. Sob esse ponto de vista, a natureza não teria direção e progressão, somente mudanças (Dove, 2001; McCabe, 2004), e - dentro relação dialética e co-evolutiva que se coloca entre a sociedade e o meio biofísico - as comunidades humanas deixam definitivamente de ser vistas com entidades passivas, moldadas exclusivamente pela relação entre os genes e as pressões seletivas ou entre as relações termodinâmicas e suas respostas socioculturais (Descola e Palsson, 1996; Feld, 1996; Tsing 2001). Portanto, pode-se considerar que as principais mudanças teórico-metodológicas desse período são: a substituição da seleção de grupo por uma análise centrada no indivíduo; a incorporação simultânea de diversas escalas de análise (dentre elas, a individual - 0 indivíduo e a unidade doméstica, a local - áreas ecológicas, a regional- comunidades e agentes externos diretos, e a global); e a ênfase em aspectos como variáveis demográficas, estresse ambiental, tomadas de decisão individuais e domiciliares, estratégias adaptativas específicas e desenvolvimento histórico local e suas articulações globais (Boserup, 1987; Fairhead e Leach, 1996; Kottack, 2006; McCabe, 2004; Moran, 1991; Neves, 1996; Orlove, 1980).

Como conseqüência dessa mudança de postura com relação análise da interface entre o homem e o ambiente natural, os processos políticos e intelectuais 
passam a ser considerados os elementos chaves na compreensão das formas de apropriação dos recursos naturais (Watts e Peet, 2004). Tal percepção motivou a releitura do marxismo em algumas escolas antropológicas, o que deu margem ao aparecimento de uma nova abordagem (ou programa de pesquisa) conhecida como Ecologia Política. Introduzida na literatura por Eric Wolf em 1972, em um artigo intitulado "Ownership and Political Ecology", a Ecologia Política aborda a confluência entre as análises ecológicas e a economia política, com foco no uso e manejo dos recursos naturais nas diversas escalas de análise anteriormente descritas (Escobar, 1999; Greenberg e Park, 1994; McCabe, 2004; Wolf, 2003). Pressupõe a idéia fundamental de que todos os ecossistemas existentes seriam produtos de uma relação histórica dialética entre os meios de produção (economia) e padrão das relações sociais, sem desconsiderar o elemento da incorporação do papel do conteúdo político-econômico supra-local, regional e transnacional (Balée, 2006; Escobar, 1999; Redclift e Woodgate 1988). E a agência política surge como um fator fundamental na luta pelos recursos ambientais locais e também como cenário principal sobre o qual incidirão as políticas ambientais (Brosius, 2001; Moore, 1997).

Dentro desse histórico de mudanças e adoção de novas perspectivas nas pesquisas situadas no campo (e sub-campos) da Antropologia Ecológica, as pesquisas etnográficas contemporâneas enfrentam um campo de estudo multifacetado, onde a influência das relações discurso/poder/conhecimento nas práticas de uso e controle dos recursos naturais são percebidas de forma cada vez mais clara (Brousius, 2001). Tornou-se evidente que os sistemas de produção e os discursos locais se interconectam historicamente com os sistemas e discursos econômicos regionais e globais (Brousius, 2001; Moore, 1997). A construção dualista natureza/cultura apresenta-se como uma construção cultural e histórica da sociedade ocidental (Viveiros de Castro, 2002; Descola e Palsson, 1996; Dove, 2001; Escobar, 1999). Dessa forma, houve a consolidação, no cenário acadêmico ,de que a compreensão dos processos ecológicos não poderia mais estar dissociada da produção simbólica e de significados, já que são forma e conteúdo da transformação material (Balée, 2006; Dawson, 2002; Escobar, 1999; Moore, 1997; Wehling, 2002; Redclift e Woodgate 1988). O próprio conceito de "natureza" é freqüentemente problematizado em estudos de interface entre as Ciências Sociais e a Ecologia (Viveiros de Castro, 2002; Descola e Palsson, 1996; Dove, 2001; 
Escobar, 1999). Cada vez mais esse termo é percebido como produto de uma simbologia diversa dentro da pluralidade cultural presente no mundo. Paralelamente, sabe-se que, mesmo dentre "sociedades modernas" ocidentais em particular, o que conhecemos por "natureza" passa por um processo de re-significação contundente, dentro de uma lógica de mercado que domina paulatinamente as visões humanas do mundo (Descola e Palsson, 1996). O paradigma dualista cartesiano, que apartou o homem do meio natural, tornou-se artificial frente às novas agendas teóricas da Antropologia, da Ecologia e de outras disciplinas relacionadas que têm problematizado a relação entre o homem e ambiente biofísico (Viveiro de Castro, 2002; Descola e Palsson, 1996; Dove, 2001; Kottak, 2006; Murrieta, 2001; Neves ,1996; Orlove, 1980).

Dentro dessa perspectiva, consolidam-se os estudos dentro do campo da Etnobiologia. Originado da Antropologia Cognitiva, esse campo teórico-metodológico busca entender como o mundo (biológico) é percebido, conhecido e classificado por diversas culturas humanas (Posey, 1987). Na Etnobiologia os focos principais são, portanto, as categorias e conceitos cognitivos (Barrera-Bassols e Toledo, 2005; Posey, 1987). Trata-se de um campo que tem caráter interdisciplinar e cross-cultural, qualidades exigidas a uma ciência que trata das relações entre os mundos natural, simbólico e social (Barrera-Bassols e Toledo, 2005; Posey, 1987). Produz, ainda, informações sobre o conhecimento ambiental das sociedades humanas, contribuindo com técnicas de conservação, bem como auxiliando no conhecimento biológico sobre os organismos e suas interações (Begossi, 2002). Associado a este programa, a Etnobotânica, seria a vertente de investigação etnobiológica com enfoque no domínio vegetal. É, portanto, também um programa interdisciplinar que abrange fatores biológicos e culturais (Begossi, 2002; Ribeiro, 1996). Segundo Millot $(1968)^{3}$, a Etnobotânica não tem métodos próprios, associando a botânica, a etnografia e/ou sociologia (Millot, 1968 apud Ribeiro, 1996). Amorozo e Gély (1988) ressaltam que os estudos etnobotânicos são imprescindíveis, principalmente nas áreas tropicais, onde as populações nativas estão submetidas a um sincretismo inevitável com a cultura dominante da sociedade envolvente, produzindo uma grande perda na transmissão do conhecimento sobre plantas selvagens para as

\footnotetext{
${ }^{3}$ MILLOT, J. L'ethnobotanique .Em: Ethnologie Générale. Paris: Gallimard. 1968.
} 
futuras gerações e resultando, em última instância, na perda do que tem sido chamado de "conhecimento tradicional" 4 . No Brasil, vários pesquisadores vêm se dedicando ao estudo etnobotânico de diversas comunidades humanas, como Albuquerque e colaboradores (2005), Amorozo e Gély (1988), Begossi (2000, 2002), Cardoso e colaboradores (2001), Figueiredo e colaboradores (1997), Garrote (2004), Hanazaki e colaboradores (2000), Peroni e Hanazaki (2002), Prance e colaboradores (1987), Posey (1987), Ribeiro (1996).

Atualmente é difícil pensar a Antropologia Ecológica como uma base teórico-metodológica única. Alternativamente, é comum percebê-la como um campo pulverizado em muitos outros programas de pesquisa, como, por exemplo, os tratados nesta seção (Ecologia Política, Etnobiologia e Etnobotânica). Portanto, os estudos contemporâneos que reportam a relação entre sociedade (cultura), e ambiente natural (material) geralmente congregam o máximo de abordagens que de fato auxiliem a compreensão dessa interface. Nesse caso, o desafio é realmente incorporar a visão de uma construção conjunta do físico e do social, antes mesmo de visualizarmos os meios pelos quais esses dois domínios se correlacionam (Freudenburg, 1995).

\subsection{0 campesinato latino-americano}

As populações humanas que habitam as florestas tropicais encontram-se no epicentro dos debates proporcionados pelos estudos que se situam na interface

\footnotetext{
${ }^{4}$ A definição de "conhecimento tradicional" (ou "comunidade tradicional") é geralmente problemática porque freqüentemente não considera migrações recentes e/ou inclui inadvertidamente parte de uma população que já incorporou em seu sistema produtivo práticas agrícolas intensivas pós-industriais voltadas primordialmente para atender as demandas de mercado (Hanazaki, 2001). No âmbito deste estudo, serão considerados grupos tradicionais aqueles que possuem um histórico familiar claramente ligado a práticas agrícolas de subsistência e que, mesmo tendo se adaptado a condições socioeconômicas recentes (resultantes principalmente do aumento populacional e do processo de urbanização de bairros rurais), estão em constante busca por manter ou reafirmar uma identidade pública relacionada a aspectos sociais, culturais e econômicos das gerações passadas. Estes aspectos abrangem: permanência na região por muitas gerações; uso de técnicas de baixo impacto ambiental; reminiscência de sistemas sociais de distribuição de recursos (como mutirões, festas e feriados religiosos); amplo conhecimento sobre a dinâmica e composição florística do ambiente natural que habitam; e tradição em se transmitir o conhecimento de práticas agrícolas antigas e ecologia do ambiente natural habitado de geração para geração (Crockett, 1988; Cunha e Almeida, 2000; Hanazaki, 2001; Queiroz 2006).
} 
sociedade (cultura)/ambiente natural (físico). Geralmente, essas sociedades (sejam elas indígenas ou campesinas) compõem um cenário que apresenta, de um lado, uma paisagem natural altamente fragmentada (como geralmente são os remanescentes habitados por essas comunidades); e de outro, essas comunidades pobres rurais que dependem criticamente desse mesmo ambiente natural para sua subsistência. Essa perspectiva impulsionou um amplo debate no cenário acadêmico sobre a conceituação do campesinato e a definição de uma provável identidade campesina, principalmente a partir da década de 60 (Cancian, 1989; Chayanov, 1966; Pereira de Queiroz, 1973; Wolf, 1955; Wolf, 2003; Woortmann, 1995).

As principais linhas de pensamento provenientes dos estudos sobre 0 campesinato dividem-se entre a escola européia (ou economicistas europeus) e a americana (ou culturalistas norte-americanos) (Chayanov, 1966; Wolf, 1995 e 2003). A perspectiva européia fundamenta-se em uma ótica econômica baseada na unidade familiar (Chayanov, 1966; Woortmann, 1995). Para Chayanov (1966), a família seria: "um conjunto de produtores e de consumidores (...) uma unidade força de trabalho e de consumo centrada num casal e seus filhos, aos quais se podiam agregar outros membros". (Woortmann, 1995, p.29). A família camponesa, portanto, estaria ocupada em reproduzir seus "fatores de produção", como, por exemplo, a terra (Woortmann, 1995). O sistema econômico criado nesse cenário seria essencialmente baseado nas relações de trabalho do grupo doméstico. No limite, as relações internas à família passam inclusive a ser interpretadas apenas como relações de trabalho (Chayanov, 1966). Em oposição ao trabalho assalariado, o trabalho familiar (base da economia camponesa), bem como os demais elementos desse sistema produtivo, estabeleceriam leis com natureza distinta das que regulam a produção capitalista. Com algumas variações, o pensamento economicista não passou dos limites da unidade doméstica, e desenvolveu estudos principalmente sobre o campesinato russo e francês (Woortamnn, 1995). Não foram exploradas as relações entres as famílias, muito menos a relação da comunidade campesina com a sociedade mais abrangente.

A compreensão do camponês a partir de uma totalidade (e não a partir unicamente de suas relações internas) começou a se desenvolver a partir da linha de pensamento trabalhada pelos culturalistas norte-americanos, dentre eles, Eric Wolf $(1955,2003)$. A partir da investigação do campesinato latino-americano, essa 
visão mais vertical considera os campesinos como resultado de um processo histórico, que polarizou a sociedade mais abrangente de maneira a se criar uma "cultura do campesinato" (Cancian, 1989). Cancian (1989) apresentou os campesinos da região de Zinacantan (México) como uma população rural formada por comerciantes conectados com lugares distantes antes mesmo da colonização espanhola. A partir da conquista, porém, ficaram sujeitos a mudanças nas políticas públicas ditadas pelos conquistadores e pelo Estado Nação ao qual estavam submetidos. Portanto, percebe-se que a conexão destas populações rurais com o mundo a sua volta é antiga e importante. Por outro lado, os campesinos de Zinacantan nunca deixaram de ser produtores de sua própria subsistência, falando, inclusive, sua própria língua e mantendo sua própria tradição cultural (Cancian, 1989). O camponês latino americano é, por razões óbvias, sempre pensado a partir do modelo de dominação colonial hispânico ou luso (Woortmann, 1995). Maria Pereira de Queiroz (1973) também atenta para a importância em se discutir a relação estreita entre o campesinato e os outros setores da sociedade dentro da qual essas populações tradicionais (rurais) estão inseridas. Segundo a autora, o binômio cidade-campo exprime a noção de que o camponês, por definição, só passou a existir depois de estabelecida a primeira cidade. As populações indígenas (aborígenes, dentro outros) seriam anteriores a esse processo, e não se encontram, portanto, dentro de tal conceituação. Considerando esse panorama, a cidade agiria como poder central, e os campesinos estariam sujeitos a uma subordinação política, tendo, ainda, um papel de complementação econômica com a cidade (Pereira de Queiroz, 1973). O grau de relativo isolamento dos campesinos em relação aos outros setores sociais (regionais ou nacionais) mudam ao longo do tempo, nunca tendo havido, porém, um isolamento total (Cancian, 1989).

A vertente antropológica norte-americana dos estudos do campesinato abarca diversas correntes de entendimento do sistema social e produtivo das populações rurais estudadas. Cancian (1989) discorre sobre três abordagens principais. Uma delas, proveniente dos chamados "teóricos da diferenciação", aborda principalmente a influência do sistema econômico mais abrangente sobre os campesinos. O enfoque desse eixo é, portanto, compreender a história de transição dessas populações, de produtores relativamente independentes de sua subsistência, para residentes rurais que necessitam vender seus produtos e sua força de trabalho para 
sobreviverem (Cancian, 1989). A segunda abordagem, proveniente dos chamados "teóricos da homogeneidade", propõe uma visão do campesinato em duas frentes: sua condição socioeconômica, e os processos que mantém essa condição geral sem grandes mudanças ao longo do tempo. Parte-se do pressuposto de que as organizações social e econômica dos campesinos seriam significativamente diferentes da organização de livre mercado (capitalista), moderna e industrial - que estimula o acúmulo individual de bens e leva à diferenciação socioeconômica e heterogeneidade (Cancian, 1989). A terceira abordagem provém dos chamados "teóricos da heterogeneidade", e é baseada na pressuposição de que os campesinos são essencialmente similares a qualquer outro setor da sociedade. Sendo assim, não impõem qualquer resistência à mudança de sua organização social ou econômica, nem mesmo a uma potencial incorporação plena por outros setores da sociedade.

Convém observar que, de maneira geral, as grandes teorias sobre o sistema produtivo e a organização social camponesa estão limitadas a realidades mais ou menos estanques, que correspondem cada vez menos à realidade fluida e dinâmica vivida atualmente. Dentro dessa fluidez crescente, muitas comunidades campesinas congregam elementos enfatizados pelas várias abordagens discutidas anteriormente, considerando tanto de uma perspectiva sincrônica quanto uma diacrônica (histórica). Diante desse impasse, torna-se conveniente particularizar determinados elementos-chave na definição dessas populações, e que são compartilhados de maneira relativamente generalizada entre elas. Dentre esses elementos, os principais dizem respeito a localização geográfica, o grau de subordinação econômica e política, e a habilidade em produzir a própria comida (Cancian, 1989). A partir disso, podem ser traçadas algumas características comuns a esse segmento social. Os campesinos seriam produtores agrícolas com efetivo controle da terra, mas que consideram a atividade agrícola apenas como um meio de vida, não um negócio visando lucro (economia de subsistência) (Cancian, 1989; Pereira de Queiroz, 1973; Wolf, 1955). Ou seja, possuem relativa autarquia (poder sobre si mesmo), sendo esta um dos componentes centrais da sua lógica de reprodução econômica (Woortmann, 1995). A família deve ser considerada um ponto central, uma vez que é a unidade produtora e consumidora desse sistema econômico (Woortmann, 1995). A terra, por sua vez, não pode ser considerada 
apenas um fator de produção, sendo também carregada de valores simbólicos (Woortmann, 1995). São populações pobres tanto em sentido absoluto quanto em relação a muitos não-campesinos, sendo também subjugados política e economicamente (Cancian, 1989; Pereira de Queiroz, 1973; Wolf, 195; Woortmann 1995). De maneira geral, possuem menor dependência dos produtos de mercado e relativo isolamento geográfico, apesar de ser essencial considerar que seus "grupos de descendência se estendem para muito além da condição camponesa" (Woortmann, 1995, p. 54). (Cancian, 1989; Pereira de Queiroz, 1973; Wolf 1955). Sob estes aspectos, diferem das minorias étnicas urbanas porque são rurais e usualmente produzem uma porção significativa de sua alimentação (Cancian, 1989).

A caracterização de tipos de campesinato ao redor do mundo, e as várias tentativas de definição desse segmento social, são pontos essenciais para o desenvolvimento de estudos sobre o tema. Principalmente se considerarmos que estas populações, apesar de sempre terem estabelecido alguma conexão com a economia regional, estão, nas décadas recentes, se tornando gradativamente mais inseridas e diretamente dependentes do sistema econômico mais abrangente (Cancian, 1989). De acordo com Boserup (1987), este processo iniciou-se como um efeito do crescimento populacional sobre os sistemas agrícolas pré-industriais. A demografia (ou mudança na densidade populacional) seria um fator gerador de mudanças nos métodos e na tecnologia agrícola (ou seja, no conjunto de atividades necessárias num dado sistema agrícola) (Boserup, 1987). Em linhas gerais, a as transformações propostas pela autora seguiriam o seguinte panorama: uma vez atingida certa densidade populacional (aliada à uma impossibilidade na expansão da área cultivada), uma dada sociedade pode optar pelo encurtamento do pousio para ter suas demandas por alimento atendidas. Dessa maneira, aumenta-se a freqüência de cultivo em uma dada área. O plantio sucessivo em uma mesma região altera completamente o sistema usual, de modo que a fertilização do solo não é suficientemente alcançada apenas com as cinzas provenientes da queima da grande quantidade de biomassa disponível do corte de uma mata em período avançado de regeneração. $O$ encurtamento do pousio também acarreta problemas na irrigação, e facilita a ocupação do solo por ervas daninhas. Todas essas alterações acabam por requerer um maior investimento em termo de tempo de trabalho e capital, incluindo a implementação e/ou mudança dos instrumentos agrícolas (por exemplo: utilização 
de adubo animal, de canais de irrigação e da enxada ou até arado). Se esse maior investimento é economicamente compensador para a sociedade que passa por esse processo gradual de transformação demográfica, as mudanças discorridas de fato ocorrem, e parte-se finalmente para o que se pode denominar de "sistema intensivo" (Boserup, 1987). A intensificação dos sistemas agrícolas pré-industriais acarreta alterações não apenas no aspecto tecnológico e metodológico das sociedades que passam por esse processo. O sistema de cultivo do solo pode ser encarado como parte do padrão de organização social, de maneira que a passagem do seminomadismo para o assentamento permanente pode transformar profundamente uma dada população humana (Boserup, 1987; Cândido, 1971; Goody, 1994; Queiroz, 2006). A necessidade de se deslocar (em função da procura por lotes de terra que permaneceram em descanso por uma geração ou mais) impediria, de certa forma, uma "vida comunitária assentada, de modo que é pouco provável o desenvolvimento de uma organização social estável" (Boserup, 1987, p.82; Cândido, 1971; Goody, 1994; Queiroz, 2006). Conseqüentemente, não haveria a formação de uma hierarquia social complexa, ou divisões de trabalho consolidadas (incluindo as atividades não ligadas diretamente à agricultura). $\mathrm{O}$ assentamento, por outro lado, permitiria a gradual substituição dos grupos esparsos (que reuniam-se em poucas ocasiões em função do "centro provedor de sal, da administração e do ministério religioso") por vilas e, posteriormente, cidades (Boserup, 1987; Cândido, 1971). Dessa forma, estaria formado o cenário que permite (ou, em outras palavras, que seria o início) do processo de urbanização de uma da sociedade campesina em transformação. A urbanização das fronteiras agrícolas é um processo cada vez mais corrente no cenário nacional, e já foi descrito para diversas comunidades de pequenos produtores agrícolas na Amazônia (Browder e Godfrey, 1997). Neste processo, os mecanismos institucionais (que regulam e permitem a fluência do capital para e da fronteira urbano-rural) teriam o papel de definir a profundidade e a extensão da integração dessas áreas de confluência dentro da economia regional e nacional (Browder e Godfrey, 1997). É importante considerar também que os diferentes grupos externos que atuam nas comunidades em transformação relacionam-se de formas distintas com o capital, atribuindo a esse cenário de mudança um caráter ainda mais dinâmico (Browder e Godfrey, 1997). Portanto, dentro dessa perspectiva geral, alguns elementos específicos podem ser elencados 
como fatores diretos de mudança do sistema produtivo dos campesinos: a urbanização, o avanço da pecuária e o aumento da densidade populacional (Bray et al., 2003; Byron e Arnold, 1999; Kulikoff, 1993; Kumar e Nair, 2004; McSweeney 2005; Metzger 2003a, Pedroso-Júnior et al., 2008a e 2008b). Outra questão importante a ser ponderada é fato de que o envolvimento das comunidades campesinas nas relações de mercado tem, atualmente, uma magnitude muito diferente daquela que predominava antes do advento das sociedades industriais (Wolf, 2003). Cada vez mais agencias do governo (estado) controlam o que plantam e a maneira como comercializam a produção agrícola, porque dependem do estado para conseguirem sementes, fertilizantes e créditos necessários para a produção (Cancian, 1989). Apesar da ampliação do envolvimento com o mercado, o lucro obtido com a venda é geralmente usado para apenas comprar bens e serviços de que precisam para subsistir e manter seu status social: raramente amplia-se a "escala de operações" ${ }^{5}$ (Wolf, 2003, p. 120).

A complexa adaptação econômica da unidade familiar campesina frente às mudanças discorridas, por sua vez, geralmente combina a produção de subsistência com trabalho assalariado em cidades próximas ou em fazendas com larga escala de produção (Cancian, 1989). A transformação dos camponeses em uma classe de semi-proletariados de trabalhadores diaristas gera mudanças no setor agrário, como o gradativo abandono ou diminuição das áreas destinadas à agricultura de coivara e/ou a intensificação (aumento da utilização ou da produtividade da terra com diminuição dos ciclos de cultivo e introdução de cultivares perenes).

Paralelamente às questões apontadas acima, vivencia-se, atualmente, um período de crescente preocupação com a preservação dos ambientes naturais. Tornou-se, portanto, cada vez mais pungente que qualquer sistema de exploração, seja "tradicional" ou não, responda ao paradoxo constituído pela necessidade de preservação do meio natural e manutenção (e melhoria) da qualidade de vida humana. De uma perspectiva ecológica, os processos de intensificação agrícola e erosão dos sistemas "tradicionais" resultariam na perda de diversidade de cultivares e das técnicas locais de uso do solo, bem como dos demais elementos que constituem o repertório etnobotânico dessas comunidades (Adams, 1994; Pedroso-

\footnotetext{
${ }^{5}$ Aumento do trabalho e capital por unidade de área, da produtividade da terra, do excedente de produção para venda, seleção e cultivo de variedades com maior aceitação no mercado, utilização ampla de inovações técnicas e ferramentas agrícolas pós-industriais diminuição dos ciclos de cultivo.
} 
Júnior et al., 2008a). Aliado a isso, a redução do período de descanso no sistema agrícola de corte-e-queima ocasiona, ainda, uma paisagem mais homogênea, largamente dominada por roças e capoeiras (Metzger, 2003b). Dessa forma, há o desaparecimento crescente de formações florestais maduras, o que pode levar à extinção local de espécies, redução do fluxo de sementes (tanto por causa do desaparecimento das fontes dos vetores), aumento da competição com sementes de ervas daninhas e redução na velocidade do processo de regeneração (Metzger, 2003b). A gradativa simplificação e conversão de técnicas menos agressivas ao meio natural em outras mais intensivas e impactantes (Metzger, 2003b; McSweeney, 2005) tem como resultado a simplificação e a geração de um ecossistema que requer constante intervenção humana a altos investimentos externos (Altieri, 1999). A diversificação das estratégias de subsistência desses agricultores, por outro lado, também depende criticamente da preservação das práticas agro-ecológicas e do capital social local (Altieri et al., 1987). Estes elementos são resultado da coevolução de várias décadas entre o ecossistema florestal e a organização socioeconômica local, e por isso são alternativas diversificadas e concretas a mudanças e transformações de várias naturezas (social, econômica, ambiental).

Essa perspectiva estimulou a conversão, dentro das políticas públicas voltadas para as questões ambientais, de um âmbito moral/político para um de governamentabilidade, manejo, burocratização e institucionalização (Brosius, 2001). Esse processo trouxe à tona, principalmente a partir da década de 80 , lemas como "uso tradicional do solo", "uso sustentável de recursos", e "desenvolvimento sustentável" (Relatório de Bruntland, 1987). A sustentabilidade propõe uma visão holística, dentro da qual uma multiplicidade de estratégias (baseadas na diversidade temporal e espacial dos sistemas produtivos) poderia originar uma relação harmônica entre elementos sociais, econômicos, políticos e ambientais (Stone, 2003). Na maioria das vezes, no entanto, a análise de sustentabilidade de um sistema aborda apenas um desses elementos. A abrangência do termo sustentabilidade e suas definições pouco claras tornam a aplicabilidade dessa noção extremamente problemática (Cuffaro, 1997; Paterson, 2006; Robinson, 1993; Stone, 2003). Segundo Godoy e Lubowski (1992), a sustentabilidade é um resultado de condições especiais que devem ser identificadas caso a caso. Níveis de exploração são determinados pela complexa interação entre o potencial do meio ambiente e as 
aspirações de estilo de vida, tecnologias, organização sociopolítica e econômica da população associada (Harwood, 1996; McSweeney, 2005; Robinson 1993). A despeito dessa avaliação crítica, slogans como o de "sustentabilidade" vêm ganhando cada vez mais força no cenário mundial. Eles se baseiam livremente na proposta de que o relativo equilíbrio dos ecossistemas naturais não poderia ocorrer sem a presença das práticas milenares e das populações que dependem do ambiente natural para sua subsistência. Uma importante conseqüência dessa livre associação é que ao invés de ocorrer uma diluição da identidade campesina (como se previa diante de todos os fatores relacionados à globalização e à modernidade), esta vem se reafirmando em diversos locais onde se apresentam conflitos sócioambientais, por questões predominantemente políticas.

Como é possível depreender da discussão apresentada anteriormente, a série de transformações pelos quais o campesinato de uma maneira geral (e o latinoamericano de maneira particular) vem passando não atingem diretamente apenas as esferas econômica, ambiental e social, mas também a esfera política. Isso evidencia ainda mais a relevância dessas questões para a sociedade humana de maneira geral.

\subsection{Os sistemas agrícolas tropicais baseados na coivara}

O sistema produtivo agrícola camponês é importante não apenas para o entendimento da dinâmica ecológica em muitos remanescentes de floresta tropical. As práticas, técnicas e conhecimentos associados a este sistema vão além da esfera econômica das comunidades locais, atingindo as esferas social, cultural e identitárias das mesmas. Portanto, a despeito das argumentações teóricas mais amplas concernentes ao sistema de campesinato, cabe aqui discorrer brevemente sobre a base do seu sistema agrícola.

Os campesinos (e indígenas) que habitam ambientes tropicais encontram algumas limitações biofísicas cruciais a serem suplantadas para a implantação de um sistema produtivo bem sucedido (no sentido de proporcionar a subsistência e manutenção dessas populações ao longo dos anos). Dentre eles, estão: a baixa 
fertilidade do solo, a ameaça de invasão do solo por ervas daninhas, e os danos causados a lavoura por invertebrados (como formigas), pestes microbiais e vertebrados (como veados, catetos, roedores em geral). Através de uma relação milenar e co-evolutiva, as sociedades humanas que habitam os trópicos úmidos desenvolveram estratégias de uso e manejo do solo que superaram satisfatoriamente esses impasses. O plantio extensivo rotativo e a utilização da biomassa vegetal local como fonte energética (diminuindo, desta forma, o input de energia e nutrientes por unidade de área) são duas das principais técnicas que permitiram a sobrevivência dessas sociedades nesses ambientes florestados desde a pré-civilização até os dias de hoje (Adams, 2000; Boserup, 1987; Conklin, 1961; Dean, 1996; MacGrath, 1987; Pedroso-Júnior et al., 2008a). Além das limitações ambientais, as famílias campesinas e indígenas lidam ainda restrições na disponibilidade de mão de obra disponível para a produção agrícola (Boserup, 1987; Pedroso-Júnior et al., 2008a). O sistema agrícola conhecido por "corte-e-queima" (ou coivara), reúne, tradicionalmente, estes elementos principais sendo, portanto, a base da subsistência de diversas populações pobres rurais em todo o mundo (Adams, 2000; Altieri et al., 1987; Boserup 1987; Pedroso-Júnior et al., 2008a). A coivara possui uma baixa produtividade em termos de investimentos externos por hectare do total da terra cultivada (incluindo as áreas em regeneração) comparada com outros sistemas (modernos), mas possui um alto retorno relativo em termos de trabalho (Angelsen, 1995; Metzger, 2003). Adicionalmente, a eficiência desse tipo de agricultura nesses ambientes está ligada a fatores como a disponibilidade de terra para o pousio, o conhecimento do histórico do uso da terra, suas condições físicas e as espécies indicadoras associadas aos estágios de sucessão florestal, bem como o respeito ao calendário agrícola (Pedroso-Júnior et al., 2008a; Sanches, 2004).

As diversas definições acerca do que se conhece sobre agricultura de coivara priorizam alguns traços distintos dessa prática, como a periódica troca de campo de cultivo (itnerância), a queima e o pousio (MacGrath, 1987; Pedroso-Júnior et al., 2008a). Os campos de cultivo são rotacionados com objetivo de explorar a energia e os nutrientes disponibilizados pela vegetação natural. Em alguns casos, esta pode constituir a única fonte de nutrientes para os cultivares (MacGrath, 1987; PedrosoJúnior et al., 2008a). O corte e a queima da vegetação ocorrem na estação seca, aproveitando as cinzas como nutrientes para o desenvolvimento da plantação no 
início da estação chuvosa (Angelsen, 1995; Conklin, 1961; Dean, 1996; Harwood, 1996; Metzger, 2003a; Pedroso-Junior et al., 2008b). O declínio da fertilidade do solo e o aumento dos problemas de ervas daninhas levam os agricultores a abandonarem os campos após poucos anos de cultivo (Angelsen, 1995; PedrosoJúnior et al., 2008a). Outros tipos de vegetação (espécies pioneiras dominantes) ocupam essa paisagem e inicia-se o processo de regeneração florestal (Angelsen, 1995; Pedroso-Júnior et al., 2008a; Tabarelli e Mantovani, 1999). É importante considerar que a velocidade de regeneração da Floresta Tropical Atlântica depende de questões específicas, e que variam de acordo com o contexto local (Guariguata e Dupuy, 1997; Tabarelli e Mantovani, 1999). Os principais elementos de variação na velocidade de regeneração são a intensidade da perturbação e alguns fatores ambientais, como as condições edáficas, topográficas (levando-se em conta principalmente a diferença entre terras baixas e altas nas florestas tropicais úmidas) e climáticas (Brown e Lugo, 1990; Guariguata e Dupuym 1997; Tabarelli e Mantovani, 1999). Por haver essa distinção, torna-se difícil mensurar o período exato em anos para que a floresta tropical de terra firme (estabelecida em áreas de cultivo abandonadas) passe a apresentar valores de biomassa semelhantes aos da floresta madura. Segundo Saldarriaga \& Uhl (1991), esse período variaria entre 140 e 200 anos. Já para Brown e Lugo (1990), essa faixa estaria entre 60 e 80 anos. O tempo descanso (repouso ou pousio), por sua vez, não costuma ser superior a 30 anos, podendo ser interrompido até passados apenas 5 anos do abandono (Angelsen, 1995; Boserup, 1987; Dean, 1996; Pedroso-Júnior et al., 2008a). Dessa maneira, é comum que algumas variedades cultivadas permaneçam na capoeira até o momento que ela é novamente derrubada e utilizada (Hanazaki, 2001). Variedades agrícolas que permanecem na capoeira em regeneração passam a compor a diversidade florística da mesma, de maneira que capoeiras de mesma idade provenientes de diferentes tipos de uso do solo (por exemplo, agricultura mecanizada com cultivares perenes, pastagem, e agricultura de coivara) possuem variados índices de diversidade em sua composição vegetal (no exemplo apontado, uma diversidade crescente) (Begossi et al., 2000; Brown e Lugo, 1990, Pereira e Vieira, 1991).

O tempo de pousio pode, ainda, ser um elemento central para classificação dos sistemas de uso do solo nos trópicos (Boserup, 1987). Boserup (1987), por exemplo, classifica os sistemas correntes de uso da terra pelas populações pobres rurais que 
habitavam ambientes florestados na década de 60 adotando o tempo de pousio variável como fator de definição principal. O cultivo de pousio longo ou florestal seria aquele em que a plantação é cultivada por um ano ou dois e é depois abandonada por um período longo suficiente para que haja regeneração florestal (de 20 a 30 anos pelo menos) (Boserup, 1987). O cultivo com pousio médio seria aquele alterna períodos de cultivo variando de 1 a 8 anos, e de pousio variando entre 6 e 10 anos. No cultivo com pousio curto, o tempo de abandono da plantação era 1 ano ou 2 apenas. No cultivo anual, o repouso duraria apenas alguns meses. Por fim, os cultivos múltiplos, seriam sistemas onde uma mesma área suportaria duas ou mais lavouras ano após ano. A "Mata Virgem", segundo a mesma autora, seria aquela que jamais foi cultivada ou que está sem cultivo há 1 século ou mais, o que é congruente com a proposta de Saldarriaga \& Uhl (1991) (Boserup, 1987). Atualmente, a tomada de decisão com relação ao tempo de pousio é pautada por diversos fatores como a disponibilidade de terra, pressão demográfica (demanda pela produção agrícola), e a estrutura do mercado.

A agricultura de coivara não é um sistema estático nem necessariamente um sistema estável. Os agricultores podem adaptar suas estratégias de cultivo em função de mudanças lineares e cíclicas, de âmbitos social, econômico e natural (Pedroso-Junior et al., 2008a). Podem ser mudanças, por exemplo, na composição e demandas da unidade doméstica, nos tipos de vegetação disponíveis e mudanças climáticas (MacGrath, 1987). Por isso, esse sistema agrícola pode variar conforme a localização geográfica, características topográficas, contexto cultural, disponibilidade de terra, trabalho, capital econômico, padrão de assentamento, grau de interação política e social com outros segmentos da sociedade, tipos de cultivo disponíveis, tipos de interação e sucessão entre os cultivares, dispersão agrícola, uso específico de técnicas e ferramentas (Conklin, 1961; Pedroso-Júnior et al., 2008a). Por sua flexibilidade ecológica e cultural, acredita-se que as comunidades que praticam os sistemas agrícolas de coivara possuem maior capacidade de se adaptarem a mudanças e distúrbios, tanto naturais quanto sociais (Barrera-Bassols e Toledo, 2005; Hazanaki, 2001).

Os sistemas agrícolas tradicionais baseados na coivara têm como características centrais a alta diversidade de cultivares e a existência de subunidades agrícolas que desempenham funções distintas e interligadas dentro do 
todo (Altieri et al., 1987; Altieri, 1989). O complexo agrícola é formado por um mosaico heterogêneo, composto por áreas de roça per se, áreas onde se combinariam o cultivo de árvores e a criação de animais, capoeiras (florestas secundárias em diversos estágios de regeneração), jardins e quintais (Fernandes e Nair, 1986). Dessa forma, esses sistemas atendem a inúmeras demandas da unidade doméstica (como alimento para a os moradores e para a criação, material de construção, lenha, uso medicinal e ornamental); têm produção ao longo de diversas estações do ano; e minimizam o impacto ecológico através da geração de micro-habitats (ou zonas agro-ecológicas) (Altieri, 1999; Cardoso et al., 2001; Fujisaka et al., 2000). Esta alta diversidade é também uma prevenção contra perdas totais de lavouras ou de variedades, já que mantém um grande pool genético que permite a seleção futura em resposta a mudanças ambientais potenciais. Isso diminui a instabilidade do sistema agrícola e atribui uma alta resiliência das populações humanas que o praticam (Peroni e Hanazaki, 2002; Pedroso-Júnior et al., 2008a). Diante das qualidades referidas acima, a agricultura de coivara é vista como uma alternativa para a demanda sempre crescente por comida (Soewarwoto et al., 1985) e uma solução pragmática que associa conhecimento científico e técnicas tradicionais para diversificar a produção (Albuquerque et al., 2005).

\subsection{Caracterização preliminar dos jardins-quintal}

Os pequenos produtores rurais dos trópicos geralmente organizam suas unidades agrícolas como sistemas complexos formados por diversos subsistemas (Ali, 2005; Altieri, 1999; Altieri et al., 1987; Nair, 1993; Pedroso-Junior et al., 2008b; Posey, 1987; Soemarwoto e Soemarwoto, 1984; Sanches, 2004; Tsegaye 1997). Comumente essas unidades congregam áreas de silvicultura, áreas de roça e hortas próximas à unidade residencial, e áreas de roça mais distantes da última (e que podem ou não ser temporárias), terrenos em descanso, jardins e quintais (Fernández e Nair, 1986; Valle, 2002). Por serem relativamente inconspícuos e menos impressionantes visualmente do que os campos de cultivos, eles tendem a ser subestimados em sua contribuição para a subsistência da família (Kimber, 2004). 
Porém, o cultivo em áreas cada vez mais próximas ao complexo residencial vem se tornando uma das conseqüências adaptativas latentes das populações campesinas frente ao quadro de mudanças sociais, econômicas e políticas que enfrentam. Fairhead e Leach (1995) descrevem esse processo na Vila de Kuranko, no sudeste de Guiné. O cultivo em áreas próximas ou adjacentes ao complexo residencial, no caso apresentado pelos autores, ocorre principalmente para a manutenção de cultivares "secundários". Eles apontam, ainda, tal configuração como resultado de mudanças econômicas, políticas e sociais que alteraram a estrutura e funcionamento do sistema agrícola dos residentes locais, desde os tempos da colonização européia (Farihead and Leach, 1995). Pedroso-Júnior e colaboradores (2008b) também observaram o mesmo processo nas comunidades quilombolas de Sapatu, Pedro Cubas e São Pedro, Médio Ribeira, no Estado de São Paulo, as mesmas estudadas nesta pesquisa.

A relação entre alterações na diversidade florística e estrutura de jardins e quintais agroflorestais e o processo de absorção, adaptação ou resistência dos campesinos às pressões externas demonstra a importância desses espaços como elementos de análises da forma como essas transformações vêm ocorrendo (Cerda e Mukul, 2008; Pedroso-Junior et al., 2008b). Tal relação decorre principalmente do fato de que jardins e quintais são amplamente utilizados nos sistemas agroflorestais tropicais e constituem uma parte importante da economia doméstica das comunidades rurais. Ainda, por depender da mão de obra predominantemente familiar, espera-se que o design, organização e manejo dos jardins e quintais também seja altamente influenciado por fatores relativos à dinâmica interna da unidade doméstica (Cerda e Mukul, 2008).

Jardins, ou simplesmente o cultivo de plantas ao redor da residência, são provavelmente uma das formas mais antigas de se praticar agricultura (Niñez, 1985), tendo evoluído a partir dos hábitos sedentários que permitiram a sistematização da coleta de plantas para a domesticação (Greenberg, 1996). Embora muitos autores tenham arriscado descrever o conceito de "jardim", nenhuma definição foi universalmente aceita. Geralmente, essa terminologia se refere a um espaço em frente à casa, que estabelece a transição para o espaço público ou comum, possuindo, por essa razão, um fator estético significativo (Brito e Coelho, 2000). Compondo esse quadro, os "quintais" seriam o espaço localizado atrás da casa, 
onde as práticas de manejo estariam mais relacionadas ao cultivo de hortas e demais trabalhos ligados ao funcionamento diário da Unidade doméstica. No Brasil, o termo "quintal" é mais abrangente, sendo utilizado para se referir ao espaço do terreno situado ao redor da casa, sendo definido, na maioria das vezes, como a porção de terra de acesso fácil e cômodo, na qual se cultivam ou se mantêm múltiplas espécies vegetais com diversas funções (alimentar, medicinal, lenha para queimar, etc.) (Brito e Coelho, 2000). Dessa forma, principalmente no caso de unidades domésticas rurais, o espaço localizado dentro ou adjacente ao complexo residencial é considerado uma unidade integrada, podendo ser chamada de jardimquintal (sendo "homegarden" a tradução mais apropriada para o termo jardimquintal).

São diversas as características definidoras dos jardins-quintal, como a predominância do trabalho familiar e sua multi-funcionalidade como um espaço estético, social, recreativo e utilitário (no provimento de remédios, ervas, materiais para construção, combustível, dentre outros) (Howard, 2003). A associação com animais domésticos o caracteriza também como um locus de produção de proteína animal (Greenberg, 1996; Kumar e Nair, 2004). Sendo assim, uma de suas principais vantagens é a de fornecer segurança alimentar para população ao longo de todo o ano. Em períodos de doença ou escassez de alimento, como, por exemplo, o período da entressafra (Kumar e Nair, 2004), os jardins-quintal são sempre uma significativa fonte de diversidade alimentar para a família (Murrieta e WinklerPrins, 2003; Nair, 1993), minimizando também os riscos agrícolas (Greenberg 1996). Outras vantagens residem no valor ornamental considerável, no fornecimento de sombra para plantas e animais (Nair, 1993) e nas várias funções ecológicas que desempenha (benefícios hidrológicos, modificações microclimáticas e controle da erosão do solo, nichos para fauna e conservação de recursos genéticos (Soemarwoto et al., 1987).

Outro aspecto dos jardins-quintal é seu papel como espaço social, onde muito do tempo familiar é gasto tanto com trabalho quanto com lazer (fato que promove integração entre seus membros e possibilita sua utilidade como modelo para análise da dinâmica e estruturação familiar). Seu layout e manejo não apenas refletem o conhecimento local, mas também são produtos das diferenças no que se refere a papéis e expectativas de gênero (principalmente no caso das mulheres), por 
sua vez definidas social e culturalmente (Lok et al., 1998; Murrieta e WinklerPrins, 2003). Têm-se relatado em diversos estudos que as mulheres são as principais candidatas a iniciar os processos de domesticação de plantas e realizar o manejo local (Begossi, 1989; Brito e Coelho, 2000; Greenberg, 1996; Howard, 2003; Figueiredo et al., 1993; Kulikoff, 1993; Murrieta e Winklerprins, 2003; Tsegaye, 1997) Sua proximidade ao complexo residencial, resultante de seus afazeres "domésticos", torna-as mais capacitadas para um cultivo mais efetivo e minucioso das plantas (Greenberg, 1996; Kulikoff, 1993). Assuntos como a jardinagem, colheita de plantas, preservação pós-colheita, estocagem e processamento, são freqüentemente resolvidos por mulheres (Howard, 2003; Kulikoff, 1993). É devido a esses fatores que esse ambiente acaba por proporcionar uma oportunidade de melhoria do papel da mulher nos processos de tomada decisão da família (Murrieta e WinklerPrins, 2003). Alguns estudos mostram que a análise dos diversos níveis de conhecimento entre aqueles que manejam os jardins-quintal apontam para as mulheres como principais retentoras do conhecimento acerca das plantas medicinais (Begossi, 1989; Figueiredo et al., 1993; Howard, 2003; Murrieta e Winklerprins, 2003). Entretanto, tanto Hanazaki e colaboradores (2000) quanto Matavale e Habib (2000) não encontraram tal padrão, o que demonstra certa variação entre as regiões de estudo. Apesar disso, a maior parte dos estudos de jardins-quintal concorda em serem as mulheres as principais mantenedoras desse espaço (Brito e Coelho, 2000; Greenberg, 1996; Figueiredo et al., 1997; Howard, 2003; Murrieta e Winklerprins, 2003; Tsegaye, 1997). Jardins-quintal seriam, portanto, a parte mais feminina da agricultura familiar, pelo menos em sociedades campesinas (Murrieta e Winklerprins, 2003). As mulheres são capazes de conferir características qualitativas altamente específicas às etnovariedades do seu jardim-quintal (mesmo sendo essas incrivelmente semelhantes). São, ainda, as que definem o plantio, a colheita, capina (retirando as sementes indesejadas e deixando as úteis para a unidade doméstica), estocagem, introdução de novos materiais ao manejo do jardim-quintal e troca de informações através de várias fontes (vizinhos, amigos, parentes, mercado) (Tsegaye, 1997). Além do importante trabalho nos jardins-quintal, as mulheres inevitavelmente auxiliam na roça (em alguns casos, são elas as principais responsáveis também por esse espaço) e cuidam da casa e dos filhos. Apesar da ampla extensão de seu papel na produção da unidade doméstica, as mulheres são 
muitas vezes negligenciadas, geralmente tidas como não produtivas. Tsegaye (1997) aponta como razões principais para esse negligenciamento a não remuneração na maioria dos serviços que realizam. Soma-se a isto o fato de as próprias mulheres normalmente não darem o real valor ao seu trabalho e os homens serem considerados os chefes de família, o que os faz porta-vozes da unidade doméstica. Desse modo, a "voz" feminina é freqüentemente silenciada. Alheias a eventos sociais e políticos da comunidade, as mulheres correm o risco de inviabilizar ainda mais a sua contribuição à produção agrícola (Tsegaye, 1997).

O manejo dos jardins-quintal envolve inúmeras técnicas agrícolas para o arranjo espacial das plantas, de acordo com os requerimentos ecológicos de cada espécie, e satisfaz as necessidades do cultivador em termos de espaço e produção vegetal e animal (Greenberg, 1996). Segundo Lok e colaboradores (1998), normalmente existem três estratégias básicas inter-relacionadas empregadas no manejo desses espaços: a regulação da água e da umidade, a utilização de zonas de manejo e a tendência geral de manter - e se possível aumentar - a diversidade florística de espécies. Ainda, segundo Blanckaert e colaboradores (2004), as plantas que compõem os jardins-quintal podem ser incluídas em três categorias principais. Existiriam aquelas plantas intencionalmente plantadas e cultivadas para um fim específico; as variedades protegidas, ou seja, plantas que nascem espontaneamente e que são transplantadas e/ou estimuladas a se desenvolver e a se espalhar; e, por fim, aquelas que também nascem espontaneamente mas não são encorajadas, porém são mantidas nos jardins-quintal para o caso de um uso futuro (Blanckaert et al., 2004). Aparentemente, tanto a idade do jardim-quintal quanto seu tipo de manejo são os principais fatores de influência na estrutura vegetal (Kumar e Nair, 2004). Lok e colaboradores (1998) identificam, em geral, 5 zonas de manejo nos jardins da península de Nicoya, Costa Rica. Uma delas seria um espaço de vivência, local mais perto da casa, com pouca vegetação, comumente utilizada como um terraço onde as crianças podem brincar e os adultos descansar. Outra seria a zona onde predominam as plantas ornamentais, podendo ser encontrada em diferentes regiões no jardim e incluindo plantas em recipientes sob a sombra de árvores e/ou perto da casa. Uma terceira seria, ainda, o local onde se misturam plantas não cultivadas com árvores de diversos tipos sobrepostos a formas não domesticas, nos limites do jardim-quintal. Normalmente, essas variedades 
indígenas e selvagens (ou etnovariedades) são utilizadas como material para construção, fonte de frutas silvestres e plantas medicinais. Neste trabalho foram consideradas "etnovariedades" as plantas reconhecidas e nomeadas pela população local, possuindo uso característico entre as famílias. As etnovariedades distinguemse não apenas pela denominação que lhes é atribuída, mas também pela função e aspecto morfológico que apresentam. Além disso, esse complexo florístico serviria como proteção contra a erosão do solo. Existiria uma quarta zona, onde predominariam plantas frutíferas e árvores que produzem sombra (com o propósito de criar um micro-clima específico para o cultivo). Podem ser encontrados nessa região, ainda, diversos arbustos e etnovariedades não lenhosas. Por fim, poderia ainda ser distinguida uma quinta e última zona, que seria um local de inundação anual. Essa área seria reservada para a produção de verduras ao fim da estação úmida e começo da seca.

Estruturalmente, é comum que os jardins-quintal agroflorestais sejam compostos por um estrato de dossel vertical de 3 a 4 camadas (o estrato herbáceo, o estrato arbustivo e o arbóreo), o que normalmente resulta em uma íntima relação entre as plantas (Nair, 1993). A configuração e composição do dossel estratificado de espécies compatíveis são as características mais conspícuas de todos os jardins (Nair, 1993). Com relação ao componente arbóreo, predominam as árvores frutíferas. Os produtos dessas árvores podem proporcionar uma porção substancial de nutrientes (especialmente micronutrientes) do requerimento nutricional da dieta local (Nair, 1993). A estratificação vertical resulta em um gradiente de luz e de umidade relativa que acaba por criar diferentes nichos capazes de abrigar vários grupos de espécies para explorá-los (Kumar e Nair, 2004). Sob esse aspecto, é possível distinguir várias zonas relativamente diferentes, havendo sobreposição de estratos e contínuo recrutamento de espécies nas diferentes zonas (Brito e Coelho 2000). Fernández e Nair (1986) apresentam uma estratificação para os sistemas de quintais agroflorestais em quatro zonas: 1- (0-1m): cultivos alimentícios; 2-(1-2,5m): café com árvores e arbustos jovens, assim como plantas medicinais; 3-(2,5-5m): banana, com algumas árvores frutíferas e forragem; 4 - (5, 30m): árvores de madeira valiosa e outras espécies para forragem e lenha. Com relação à estratificação horizontal. Kumar e Nair (2004) apontam como os maiores determinantes de sua caracterização a distância e posição com relação à casa, tamanho, forma, 
composição de culturas e padrão de plantação. O número de zonas de manejo por quintal pode variar de 2 a 6 , com a predominância da ocorrência de três zonas, em sua maioria.

Fernadéz e Nair (1986) relacionam jardins-quintal menores que 1 hectare a típicos sistemas de agricultura de subsistência. A natureza das interações entre os componentes dos jardins-quintal agroflorestais varia tanto no espaço físico quanto no tempo. Brito e Coelho (2000) classificam tais interações em três categorias: diretas (forragem, criação, animais selvagens, cultivos), cíclicas (resíduos do cultivo e da criação) e competitivas (entre as diversas espécies componentes do jardimquintal). Jardins-quintal são, por fim, uma extensão da agricultura nas áreas rurais. $A$ magnitude e taxa de produção, assim como a facilidade e o ritmo de manutenção desses sistemas, dependem primordialmente da composição vegetal. Porém, embora a escolha das espécies seja determinada por uma ampla categoria de fatores ambientais, econômicos e socioculturais (Altieri et al., 1987, Murrieta e WinklerPrins, 2003) existe uma similaridade marcante com respeito à composição das espécies nos diferentes jardins das diversas regiões do Brasil, especialmente com relação aos componentes herbáceos (Albuquerque et al., 2005, Garrote; 2004; Figueiredo et al., 1997; Hanazaki, 2000). É provável que isso ocorra em decorrência do papel predominante de muitas espécies herbáceas na alimentação humana (Nair, 1993). No entanto, embora os pesquisadores tenham procurado por padrões universais, a conclusão geral é que a estrutura dos jardins-quintal varia enormemente, com apenas alguns padrões identificáveis (Barrera, 1980; Caballero, 1992 e 1994; Rico-Gray et al., 1990; Vara 1980). As variáveis funcionais e estruturais observadas nos jardins-quintal em uma determinada região seriam, portanto, determinadas por uma combinação de fatores (Albuquerque et al., 2005).

Considera-se que os jardins-quintal podem ser analisados sob diversos aspectos (Kimber, 2004). Estes, por sua vez, geralmente resultam em duas formas de abordargem: a biofísica (etnovariedades como entidades biológicas), e a sociocultural (etnovariedades como elemento cultural). Com efeito, os jardins-quintal podem ser analisados tanto pela sua estrutura e composição florística quanto como parte do espaço social da unidade doméstica. Dessa forma, a abordagem pode partir tanto considerando esse espaço como parte de um agroecossistema - e como substitutos de habitat para as comunidades naturais - quanto como espaços de 
produção e reprodução de redes de reciprocidade e relações afetivas. A influência desses dois padrões principais de análise, o biológico e o social, na formação e manutenção dos jardins-quintal, são unidades praticamente indissociáveis por tratarem de aspectos altamente interelacionados (Kimber, 2004).

Os jardins-quintal são estudados no mundo todo e podem ser divididos em quintais agroflorestais de clima temperado e quintais agroflorestais tropicais (Garrote, 2004). De fato, os "homegardens" podem ser estabelecidos em quase todas as ecozonas tropicais e subtropicais, onde predominam os modos de subsistência agrícola. No México, têm-se os "hortos familiares", na América Central, "hortos caseros", na Tanzânia, precisamente no Monte Kilimanjaro, os "Chagga homegardens" (Brito e Coelho, 2000). Com relação aos jardins contemporâneos latino-americanos, os mesmos possuem raízes históricas não apenas nos sistemas de roças aborígenes, como também em outras formas de jardinagem européia de influências ibérica e/ou Anglo/Francofila (Greenberg, 1996). Os estudos sobre jardins-quintal na América Latina têm enfatizado principalmente os aspectos ecológicos e econômicos, bem como sua possível contribuição para um suposto desenvolvimento sustentável (Albuquerque et al., 2005). Presume-se, assim, que muito da literatura nos jardins-quintal tropicais é deficiente em dados precisos a respeito da sua diversificação florística e variação. Existem poucos dados quantitativos disponíveis, bem como descrições detalhadas de sua estrutura e manejo (Albuquerque et al., 2005; Ali, 2005; Altieri, 1999; Altieri et al., 1987; Anderson et al., 1985; Bahri ${ }^{6} 1993$ apud Albuquerque et al., 2005; Cerda e Mukul, 2008; Fernadéz e Nair, 1896; Figueiredo et al., 1997; Garrote, 2004; Hanazaki, 2000; Howard, 2003; Kimber, 2004; Nair, 1993; Saragousssi et al., 1990; Tsegaye, 1997; dentre outros). Apesar de sua importância, os jardins-quintal não têm sido extensivamente estudados no Brasil (Albuquerque et al., 2005) A maioria dos estudos nos jardins-quintal brasileiros apresenta descrições qualitativas de sua estrutura, composição, organização e manejo (Albuquerque et al., 2005; Anderson et al., 1985; Bahri 1993 apud Albuquerque et al., 2005; Saragousssi et al, 1990). Somando-se a este quadro de desinformação, existe pouca documentação relativa à dinâmica social e aos múltiplos significados que os jardins-quintal possuem para aqueles que os cultivam (Murrieta e WinklerPrins, 2003).

\footnotetext{
${ }^{6}$ BAHRI, S. Les systems agroflorestiers de l'île de Careiro. Amazoniana 12, 511-563, 1993.
} 


\section{CAPÍTULO 3 \\ MATERIAL E MÉTODOS}

\subsection{Vale do Ribeira: a ocupação humana e os caipiras negros paulistas.}

O presente estudo se desenvolveu na região do médio Vale do Ribeira, ao longo do trecho da bacia hidrográfica do Rio Ribeira de Iguape situado no município de Eldorado Paulista, Estado de São Paulo. A bacia abrange, ao todo, parte do nordeste do Estado do Paraná e parte da região sudeste do Estado de São Paulo (10\% do território paulista) (Camargo et al., 1972), e situa-se há aproximadamente 370 km (sudeste) da cidade de São Paulo (Figura 3.1). De outubro de 2003 a abril de 2005 foram realizadas onze etapas de campo, sob a coordenação do Prof. Dr. Rui Sérgio Sereni Murrieta e do Doutor Nelson Novaes Pedroso-Júnior, para coleta de dados referentes ao censo demográfico e diagnóstico sócio-econômico de nove comunidades remanescentes de quilombos do Vale do Ribeira: André Lopes, Galvão, Ivaporunduva, Maria Rosa, Nhunguara, Pedro Cubas, Pilões, São Pedro e Sapatu. A partir de fevereiro de 2006 foi iniciada a seqüência de etapas de coleta de dados referentes ao presente estudo, que se limitou a apenas três das nove comunidades quilombolas citadas anteriormente. São elas: Sapatu, Pedro Cubas e São Pedro (Figura 3.1). 


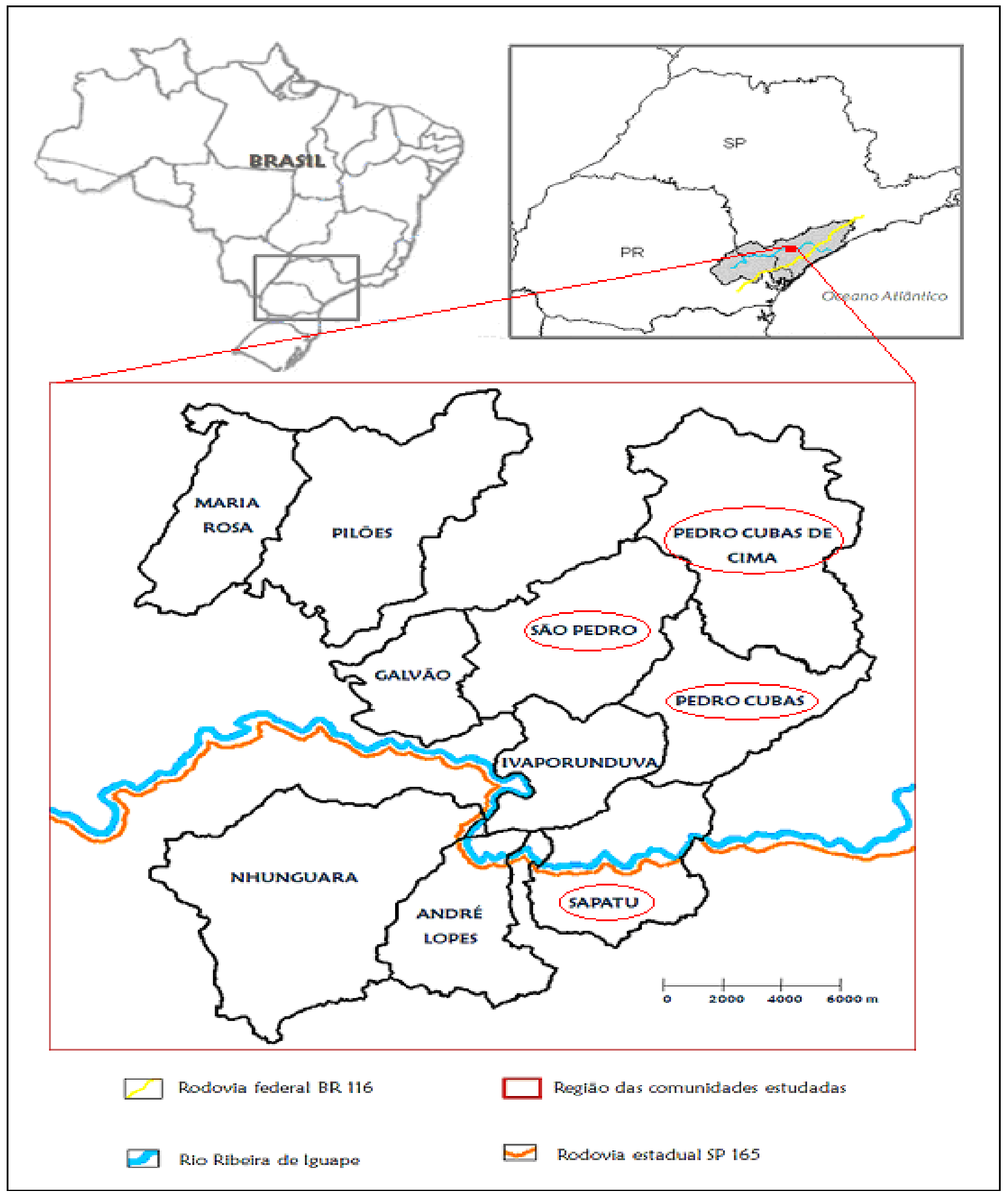

Figura 3.1: localização das 9 comunidades do Médio Ribeira visitadas previamente para a realização deste estudo (limites municipais de Eldorado e Iporanga - SP). Pontos de referência: rio Ribeira de Iguape e Rodovia Estadual SP 165. As comunidades estudadas estão circuladas em vermelho. Acima (esquerda), a delimitação do território do Vale do Ribeira (cinza), localizado entre os estados de São Paulo (SP) e Paraná (PR). Mapa construído com base em dados fornecidos pelo ITESP Instituto de Terras do Estado de São Paulo- 2000 
O Vale do Ribeira sofreu ocupação humana desde o período pré-colombiano (Dean, 1996). Antes da chegada dos europeus ao Brasil, a região da Baixada do Ribeira era habitada por índios guaianás e Carijós (Dean, 1996; Paes, 2007). Com o advento da colonização portuguesa, no início do século XVI, houve, de uma maneira geral, uma exploração mais intensiva do uso do solo frente ao regime de derrubada e queimada praticadas anteriormente pelos indígenas (Cândido, 1971; Da Silva, 2008; Dean, 1996). Dentre os principais objetivos dessa mudança no sistema agrícola introduzida pelos colonizadores estavam: fixar a população rural, confinar trabalhadores escravos, abastecer residentes urbanos e produzir excedente agrícola para exportação para os mercados europeus (Da Silva, 2008; Dean, 1996). Dessa forma, os povoados da capitania de São Vicente se organizavam em torno dos sistemas agrícolas de plantation que se firmavam na região, principalmente daqueles destinados ao cultivo da cana-de-açúcar. A produção de cana na capitania vicentina, no entanto, fracassou frente ao plantio mais bem sucedido deste cultivar no nordeste da colônia (Da Silva, 2008). Diante deste impasse, os colonos se encaminharam para o planalto paulista, e, nesse processo, adotaram amplamente as estratégias de subsistência dos grupos Tupis, ou seja, a agricultura de coivara e o cultivo da mandioca (Cândido, 1971; Da Silva, 2008; Dean, 1996). Com a expansão das missões jesuíticas, das bandeiras paulistas em busca de mão de obra escrava indígena, e as expedições exploradoras do território de consolidação da ocupação do sertão ("bandeiras povoadoras"), reforça-se o traço itinerante (ou "fenômeno de mobilidade") dos paulistas nesse primeiro e segundo séculos de colonização portuguesa na colônia brasileira (tradição iniciada pelos povos paulistas mais antigos: os indígenas) (Candido, 1971, p.35; Da Silva, 2008). Em meados do século XVII, a economia paulista se integrou a economia externa (através do fornecimento de mão de obra escrava indígena) e interna (através da produção de trigo para o mercado colonial). Essa articulação econômica estimulou a chegada de migração de um grande contingente de migrantes portugueses em terras brasileiras, o que, por sua vez, impulsionou a dinâmica de interiorização descrita previamente (Da Silva, 2008). Sobre este cenário, estabeleceu-se na região paulista o processo de "campesinização" (Da Silva, 2008, p. 65). Segundo Da Silva (2008), a "campesinização" do interior paulista está relacionada: 
"à concentração de terras nas mãos de poucas famílias, o que fazia com que aqueles que perdiam o acesso à terra penetrassem cada vez mais no território, ocupando aldeamentos e terras indígenas, consideradas pelo Estado português como devolutas." (p. 65).

Portanto, os setores mais desfavorecidos da sociedade paulista do século XVII (geralmente caboclos) eram empurrados para as fronteiras cada vez mais remotas do sertão, ficando à margem da produção mercantil colonial (mas, ainda sim, contribuindo para a sustentação deste sistema) (Da Silva, 2008).

No mesmo século, a utilização do Rio Ribeira para locomoção se intensificou devido à descoberta do ouro, e a região do Ribeira do Iguape passou a apresentar núcleos de povoamento mais densos e uma entrada massiva da mão-de-obra escrava negra (Andrade et al., 2000; Queiroz, 2006). A exploração de minérios na região foi, então, acompanhada pelo surgimento de um novo contingente populacional composto por escravos libertos, abandonados ou mesmo refugiados (Andrade et al., 2000). Dean (1996) reporta que no século XVIII :

\footnotetext{
"outros lavradores de subsistência, bem como eventuais garimpeiros em busca de ouro, ocupavam os vales acidentados a sudoeste de São Paulo, banhados pelo Rio Ribeira. Todos esses sertanejos racialmente mesclados estavam formando uma cultura distinta das vilas sob controle português. A população das vilas os chamava, desdenhosamente, de "caboclos" ou "caipiras (...) termos tupis pejorativos, com os seguintes e respectivos mais prováveis: moradores em casa de um homem branco e lenhadores da floresta" (p.119 e 120)
}

Em meados do século XVIII, com a queda da atividade mineradora, a atividade agrícola adquiriu maior estabilidade. Após a Abolição, os escravos e seus descendentes permaneceram no local, transformando-se em roceiros e ocupando as terras desvalorizadas e "sendo obrigados a constantes deslocamentos, sempre pressionados pela expansão da fronteira agrícola monocultora", como vinha ocorrendo com os setores sociais desfavorecidos citados anteriormente (Da Silva, 2008, p.75; Pereira de Queiroz, 1969). A grande interação entre esse contingente populacional com os índios que habitavam a região refletiu-se nas técnicas agrícolas, na pesca, nas formas de organização e comunicação das populações quilombolas (Andrade et al., 2000; Queiroz, 2006). Desta feita, surge, então, o que atualmente se conhece por comunidades caipiras e caiçaras, resultantes, portanto, da hibridação cultural das culturas européia, ameríndia e africana (Mussolini, 1980). (Adams, 2000; Cândido, 1971; Sanches, 2004). De acordo com Sanches (2004), estas comunidades teriam como atributos comuns justamente uma economia seminômade, de subsistência, fortemente 
baseada na unidade familiar, de forte herança indígena nas técnicas e práticas agrícolas e na interação com o ambiente natural, e "sincretismo religioso com elementos da cultura européia e indígena" (p. 54). As comunidades remanescentes de quilombos paulistas são compostas, portanto, por essa grande miscigenação cultural, e seus moradores são amplamente reconhecidos como caipiras negros (Queiroz, 2006). "Quilombo" seria "uma palavra da língua quimbundo que significa união ou ajuntamento" (Dean, 1996, 120).

Por volta de 1808 o cultivo do arroz passou a ter maior importância e tornouse uma das grandes atividades econômicas da região (atualmente a banana e o palmito detém esse papel). Em relativamente pouco tempo, essas populações formaram diversos bairros na região. Cândido (1971) caracteriza o "bairro" paulista como uma unidade mínima de relações sociais constituída por grupos de vizinhança. Neste trabalho, o mesmo significado de "bairro" é atribuído à comunidade. Tratavase de uma sociedade que se desenvolvia "à margem do sistema colonialista e escravista vigente" (RTC do ITESP 1998:4), no período. Paralelamente, a quase total ausência de estradas contribuiu para um relativo isolamento geográfico, econômico e social de região, que se voltou sobretudo para a agricultura de subsistência (Carvalho, 2006). Queiroz (2006) comenta que nessa etapa de transformação da região, "a organização econômica do povoado apresentava feições de molde tipicamente não capitalista" (p. 26), ou seja, uma organização econômica pautada no controle do principal meio de produção (a terra) pelos próprios campesinos e por uma economia de subsistência significativamente predominante.

Nas décadas de 1910, 1920 e 1930 o Vale do Ribeira mergulhou num período de estagnação econômica: a falta de empenho dos poderes públicos, no sentido de reaparelhar o sistema de transportes da Baixada, acabou por diminuir expressivamente a agricultura comercial (Queiroz, 2006). Entre o fim da década de 1930 e o início da década de 1940, porém, a política oficial de colonização incentivou a expansão oficial do cultivo da banana na região (Queiroz, 2006), o que voltou a impulsionar a agricultura comercial. A intenção oficial do Estado era a de promover a colonização nessa área, política que teve como conseqüência principal a geração de um processo de especulação no mercado fundiário, com a súbita elevação dos preços da terra (Queiroz, 2006). A despeito desta 
questão, a bananicultura possibilitou uma relativa inserção do Vale do Ribeira na dinâmica da economia nacional. Nas palavras de Queiroz (2006):

(...) a iniciativa colonizadora não objetivava qualquer inovação se comparada com as políticas oficiais anteriores; ao contrário, estruturava-se, num novo tempo e numa nova realidade, reeditando - guardadas as especificidades - os objetivos semelhantes aos das políticas de colonização que o Estado paulista procedeu nas regiões cafeeiras. (...) Nesse sentido, encontramos aqui mais um exemplo de uma política de crescimento econômico que em nada auxiliou no desenvolvimento das populações ali residentes (...) (Queiroz, 2006, p. 79).

Nos anos de 1950, a colonização é abandonada, uma vez atingidos os objetivos permanentes do governo estadual e dos grandes interesses do capital na região, inclusive a grilagem de terras (Queiroz, 2006). Por volta dessa mesma década houve a introdução de uma nova atividade econômica, o extrativismo de palmito que, segundo Queiroz (2006) “ocasionou dispersão demográfica, abandono das roças e das criações e enfraquecimento dos padrões tradicionais de entreajuda, sociabilidade e solidariedade grupais", subordinando toda a comunidade ao comprador do produto extraído (Queiroz 2006:53).

Com a construção da rodovia BR-116, atual Régis Bittencourt (inaugurada em 1961), houve uma ampliação do cultivo da banana e do chá preto (Carvalho, 2006). Em 1969, foi finalizada a construção da estrada que liga Eldorado a Iporanga, o que, ao facilitar a comunicação, destacou a existência de terras vastas e disponíveis na região do Vale do Ribeira, despertando novos interesses econômicos e a repentina valorização das terras cortadas pela rodovia (Queiroz, 2006). A maioria das terras "disponíveis" era na verdade de terras devolutas, ocupadas por poucas famílias sem amparo legal ou por famílias com títulos de posse bastante antigos (Queiroz, 2006).

No período compreendido entre 1964 e 1985, o Brasil passou por mudanças políticas e econômicas expressivas, que tiveram importantes conseqüências sociais em virtualmente todas as regiões do país. Através de um golpe de Estado (1964), foi implantado o Regime Militar brasileiro, cuja base principal de governo era a política do nacional-desenvolvimentismo. Como o nome sugere, esse sistema priorizava largamente desenvolvimento industrial no país. No entanto, foi também a partir da década de 60 que se iniciou no Brasil o crescimento expressivo da consciência entre "os servidores públicos de que a conservação, e mesmo a preservação, da 
natureza era uma das atribuições de um Estado digno" (Dean, 1996, p. 299). Essa tendência era estimulada pelos mesmos países que também forneciam o modelo de desenvolvimento econômico almejado pelo Estado brasileiro da época (Dean 1996). Ir de encontro a esse movimento global de "consciência verde" era encarado como evidência mais flagrante do atraso, de maneira que não restava aos militares outra alternativa que não a de seguir a "trilha da conservação", mesmo esta estando sempre subordinada "à meta do desenvolvimento econômico" (Dean, 1996, p. 306). Dessa forma, tanto a regulamentação da legislação quanto os órgãos estruturadores e fiscalizadores das políticas ambientais brasileiras começaram a tomar forma. Houve o estabelecimento significativo de reservas principalmente no sudeste do país (São Paulo, Paraná, Espírito Santo, Rio de Janeiro) na primeira década do Regime (1960), e em 1965 foi decretado o Novo Código Florestal (Lei no 4.771, de 15 de setembro de 1965). Tais medidas acabaram por restringir o uso do solo pelas populações brasileiras rurais que habitavam os remanescentes florestais.

Em decorrência da política militar brasileira, o desenvolvimento econômico no Vale do Ribeira foi também acelerado, sendo reforçado pelo receio de que a região fosse alvo de novos focos guerrilheiros entre fins da década de 1960 e início da de 1970 (Carvalho, 2006). Essa política atraiu para o Vale mais especuladores de terras, cuja presença veio a agravar ainda mais a já complicada situação fundiária. $A$ partir desse momento, portanto, crescem de maneira significativa as áreas ocupadas por "grandes posseiros" ou "grileiros". Fazendas formaram-se a partir da expulsão de pequenos proprietários e posseiros (Carvalho, 2006). Os conflitos por terra, violentos ou não, envolvendo os caipiras negros paulistas e os grileiros, tornaram-se extremamente comuns no interior do estado. Muitas famílias foram expulsas ou venderam suas terras a preços baixíssimos para grupos economicamente dominantes, pressionados pela situação desfavorável em que se encontravam (atritos por terra, restrição do uso solo, falta de alternativas de geração de renda) (Queiroz, 2006; Pedroso-Junior, 2008). Alguns permaneceram na região como empregados desses mesmos grupos (Queiroz, 2006; Pedroso-Junior 2008). Outras famílias abandonavam suas terras (tendo vendido as mesmas ou não) e partiam para centros urbanos próximos, receosos das conseqüências violentas que o conflito poderia gerar e estimulados pelas novas condições oferecidas pelo acesso facilitado a outras regiões através da recente construção da rodovia SP-165 
(Queiroz, 2006; Pedroso-Junior, 2008). Nesse momento, ficou evidente a fragilidade da organização familiar quilombola "quanto à sua capacidade de reprodução", fosse pelas transformações econômicas, pelas políticas oficiais, pelos conflitos pelo uso da terra, ou, ainda, pelo próprio movimento da acumulação do capital (Queiroz, 2006, p. 61). O agravamento das disputas por terra entre pequenos posseiros e os especuladores de terra impulsionou empenho político para solucionar a questão (Pedroso-Junior, 2008). Foi então que, a partir da Constituição federal de 1988, "questão quilombola" passou a integrar a agenda política nacional (de maneira significativa) (Andrade et al., 2000):

Aos remanescentes das Comunidades de Quilombos que estejam ocupando suas terras é reconhecida a propriedade definitiva, devendo o Estado emitir-lhes os títulos respectivos (Trecho do Artigo 68 da Constituição Federal de 1988).

Desde então as comunidades remanescentes de quilombos do Vale do Ribeira "tem sido gradativamente reconhecidas e tituladas pelo Estado, representado pelo órgão público responsável, o Instituto de Terras de São Paulo (ITESP)" (Pedroso-Júnior, 2008, p. 11). Segundo Carvalho (2006), os quilombolas atribuem atualmente três sentidos à denominação quilombo. Um deles seria o direito de viver onde nasceu, o direito ao território. O segundo designaria o grupo social, o grupo de pessoas que têm direito de viver onde nasceram. O terceiro sentido seria basicamente um sinônimo de raça negra (Carvalho, 2006).

Sobre as diversas transformações pelas quais os caipiras negros paulistas vêm passando principalmente a partir da década de 60, Queiroz (2006) - em um extenso estudo com a comunidade quilombola de Ivaporanduva, médio Ribeira enumerou que, localmente, as expressivas alterações sofridas pelo sistema socioeconômico tradicional podem ser avaliadas a partir da:

(...) venda das posses, integração no mercado regional, engajamento no trabalho assalariado, redução do contingente demográfico (devido especialmente à saída dos jovens), diminuição das extensões cultivadas, modificações nas regras de divisão do trabalho, assimilação progressiva de nova racionalidade econômica (Queiroz, 2006, p. 67).

Dentre os vários aspectos que refletem as alterações no bairro, este autor destaca, por exemplo, que no "tempo dos antigos", apenas sal, tecidos e querosene faziam parte da lista de compras cotidiana das famílias que 
habitavam essa comunidade rural. Com a produção agrícola e os sistemas sociais de distribuição de recursos (festas, mutirões, feriados religiosos), as famílias acabavam por dispor de recursos suficientes para adquirir esses produtos "não exigindo nem o abandono da satisfação de outras necessidades (naquela época bastante restritas), nem mesmo uma ampliação expressiva da jornada de trabalho de seus membros" (Queiroz, 2006, p. 67). Atualmente, o que se pode observar, em contrapartida, é que a maioria das mercadorias só é adquirida através de compras em dinheiro; e que o último cada vez menos provém da venda da produção agrícola, mas sim da venda da força de trabalho dos lavradores. Além disso, a mudança dos gostos e anseios aumentou significativamente os itens lista de compras, que agora incluem sal, café, querosene, tecidos, açúcar, sabão, óleo, farinha, feijão, arroz, pilhas, refrigerantes, dentre outros (Queiroz, 2006). Outra mudança significativa foi à restrição das formas sociais de distribuição de recursos, através de festas, ritos fúnebres e mutirões. Queiroz (2006) sugere que a função desse sistema sóciocultural era o de, dentre outros, assegurar o "acesso de todos os moradores aos bens (sobretudo aos alimentos), de maneira equilibrada e eqüitativa", ou seja, se tratava de "um complexo sistema de distribuição de bens" (p.110). Hoje em dia, esses ritos, mutirões e festas são muito mais escassos, o que pode estar contribuindo para uma diferenciação socioeconômica intra-comunitária mais acentuada na região.

De maneira sintética, portanto, o que está havendo nas comunidades caipiras negras do Vale do Ribeira é uma transformação rápida e continuada (principalmente a partir das décadas de 50 e 60), de uma relativa "simplicidade" da base material e da obtenção dos meios de vida, para a procura crescente de oportunidades em centros urbanos mais distantes e de satisfação cada vez maior de novas necessidades (o que depende cada vez mais do uso do dinheiro e da participação no mercado) (Queiroz, 2006). A tendência atual é o abandono completo das atividades agrícolas tradicionais, "seja em razão das crescentes dificuldades que os moradores encontram hoje para mantê-las, seja devido às exigências de soluções mais compatíveis com a nova situação" (Queiroz, 2006, p. 112). 
Diante das mudanças significativas apresentadas, atualmente são poucos os que ainda podem e conseguem praticar a policultura familiar como única fonte de subsistência, recusando-se a trabalhar nas fazendas ou em outras atividades não agrícolas (Pedroso-Júnior et al., 2008a; Queiroz, 2006). O reflexo do relativo isolamento do Vale (resultante dos processos históricos apresentados aqui e das dificuldades topográficas de acesso) foram características singulares, como os mais baixos índices de escolaridade e renda do Estado de SP, e as maiores concentrações de Floresta Atlântica do país (Hogan et al., 1999). É importante ressaltar, ainda, que foram iniciados, nos últimos anos, estudos para a construção de quatro barragens hidroelétricas ao longo do Rio Ribeira, o complexo de Tijuco Alto, empreendimento que seria realizado pela Companhia Brasileira de Alumínio e as de Batatal, Funil e Itaóca, que seriam construídas pela Companhia Energética de São Paulo (CESP) (Carvalho, 2006). De maneira geral, as atividades exercidas em tais bairros são variadas, incluindo a agricultura em pequena escala, o artesanato, extrativismo e pesca, dependendo da região que habitam. No Vale do Ribeira, predominam as atividades agrícolas que utilizam o sistema de pousio e a mão de obra familiar (Pedroso-Júnior et al., 2008a; Queiroz, 2006). As economias agrícola e extrativa dessas comunidades quase sempre são suficientes para a obtenção da subsistência familiar (Pedroso-Júnior et al., 2008a; Queiroz, 2006). A atividade extrativa inclui basicamente retirada de palmito, realizada clandestinamente na maior parte da região, e de produtos como sapé e taquara, utilizados para cobertura das casas e fabricação de alguns utensílios. O trabalho assalariado, realizado por alguns membros de algumas famílias, complementa a renda, permitindo a possibilidade de aquisição de bens e utensílios diversos não produzidos localmente (Andrade et al., 2000; Pedroso-Júnior et al., 2008a; Queiroz, 2006). O aumento significativo da extração clandestina de palmito, que muitas vezes acaba por ser a fonte principal de renda familiar, pode ser atribuído em grande parte à criação dos Parques e APAs, fato esse que acentuou as dificuldades de desenvolvimento de atividades agrícolas pelas comunidades locais (Carvalho, 2006). A extração do palmito em escala comercial aumentou o impacto da atividade sobre a floresta, bem como o abandono parcial da agricultura de coivara (Pedroso-Júnior et al., 2008a; Queiroz, 2006). Este processo, por sua vez, acarretou um maior grau de dependência em relação ao mercado para aquisição de itens antes produzidos pela própria comunidade 
(Andrade et al., 2000; Pedroso-Junior et al., 2008a). O aumento de renda pela obtenção de pensões, aposentadorias e salários também vem desempenhando um papel importante nesta mudança (Pedroso-Junior et al., 2008a). O turismo inseriu-se na região como uma oportunidade de trabalho para os habitantes locais e para os recém-chegados (Hanazaki, 2001).

Em função deste cenário histórico, existem atualmente três formas principais de pressão sobre o território: as grilagens, as restrições de uso do solo imposta pelas leis ambientais e a ameaça da construção de barragens no Rio Ribeira do Iguape (Carvalho, 2006).

\subsection{Vale do Ribeira: a Floresta Tropical Atlântica}

A região sudeste do estado de São Paulo compreende, além da ocupação humana anteriormente descrita, grande parte de Floresta Atlântica remanescente do país, mesmo restando apenas $15 \%$ de sua cobertura original no estado (Fundação SOS Mata Atlântica \& INPE, 2009; Tabarelli et al., 2005). Em termos de sua composição florística e faunística, é considerado um dos hot-spots tropicais para conservação, uma vez que, mesmo se tratando de uma área de alto endemismo biológico, está seriamente ameaçada (Myers, 2000). A área resguarda pelo menos cerca de 61 espécies vegetais e animais consideradas ameaçadas de extinção no Estado de São Paulo, pelo menos 25 globalmente ameaçadas (Olmos et al., 2004). Destas 25, três são prioridades de conservação do mundo (Miranda e Mattos, 1992). Originalmente distribuída desde a costa nordeste até a costa sul do país, e abrangendo diversas fisionomias, atualmente menos de $8 \%$ da área original permaneceu. Boa parte destes remanescentes são constituídos de floresta secundária ou pequenos fragmentos que já perderam muitas espécies e sofrem pelos processos ecológicos interrompidos (Aidar et al., 2001; Fundação SOS Mata Atlântica e INPE, 2009; Myers et al., 2000; Tabarelli et al., 2005). Esses processos contribuem para a degradação da biodiversidade e da disponibilidade de recursos em geral, incluindo as perdas estocásticas, a descontinuidade do habitat (que podem tornar inviável a vida para alguns organismos) e o efeito de borda (que 
modifica o micro clima das áreas marginais) (Metzger, 2001; Metzger, 2003a). Esses fragmentos florestais estão atualmente protegidos em grande parte por leis de proteção ambiental (Sanches 2004), e estão majoritariamente situados na bacia hidrográfica do Rio Ribeira de Iguape (ver seção anterior) (Figura 3.1). Esta bacia é composta por um denso sistema de canais de drenagem e tem uma extensão estimada em $14.300 \mathrm{Km}^{2}$, sendo que aproximadamente $8.400 \mathrm{Km}^{2}$ são de áreas florestadas de Mata Atlântica (Camargo et al., 1972). A fisionomia local predominante é de floresta ombrófila densa submontana (Joly et al., 1999). O relevo varia de fortemente ondulado a montanhoso (de $20^{\circ}$ a mais de $30^{\circ}$ ) e tem altitudes em torno de 100-350 m acima do nível do mar (Theodorovicz e Theodorovicz, 2007). O clima é subtropical chuvoso sempre úmido, sem estação seca pronunciada (Setzer ,1966) e com influência significativa da Massa Polar Atlântica (Torezan, 1995). A precipitação média anual é de $1800 \mathrm{~mm}$, sendo o período mais úmido o que se estende de setembro a fevereiro, e o mais seco o de abril a agosto (Gutjahr, 1993). O solo é, de maneira geral, bastante argiloso, profundo e ácido (rico em alumínio) (Theodorovicz e Theodorovicz, 2007). O Vale do Rio Ribeira de Iguape subdivide-se em três sub-regiões principais: Baixada do Ribeira (que atinge os municípios de Eldorado, Jacupiranga, Pariquera-Açu, Registro e Sete Barras); SubLitorânea (municípios de Iguape e Cananéia) e Alto- Ribeira (municípios de Iporanga, Apiaí e Ribeira). Dos aproximadamente trinta bairros rurais remanescentes de quilombos da região, três foram estudados nesta pesquisa, todos eles no município de Eldorado: São Pedro, Pedro Cubas e Sapatu (Andrade et al., 2000). Cerca de $20 \%$ do território é protegido por Parques, Estações Ecológicas e Áreas de Proteção Ambiental - APA (Secretaria do Meio Ambiente, 1996). Dentre áreas protegidas que interferem nas comunidades, abrangendo-as diretamente e/ou restringindo de alguma forma sua atividade econômica, estão: o Parque Estadual Turístico do Alto Ribeira (PETAR); o Parque Estadual do Jacupiranga; o Parque Estadual Intervales; e, por fim, a Área de Proteção Ambiental da Serra do Mar (APA Serra do Mar), criada em 1984 e que engloba 11 municípios do Vale do Ribeira, atingindo, assim, todas as comunidades quilombolas estudadas (Andrade et al., 2000; Carvalho, 2006). A APA em questão permite a prática de atividades agrícolas de subsistência em sua área, desde que se apresente uma licença expedida pelo 
Estado que só é obtida por aqueles que possuem título de propriedade da área a ser cultivada.

A evidente importância desses remanescentes florestais para a conservação da biodiversidade brasileira, aliada ao fato desta mesma região abrigar diversos grupamentos humanos desde períodos anteriores à ocupação lusa no país, estimulou o desenvolvimento de estudos acadêmicos que repensam a visão dominante, dentro da ciência ocidental, da Floresta Costeira Atlântica como uma formação prístina (Dean, 1996; Miranda e Mattos, 1992). Essa perspectiva está de acordo com abordagens mais generalistas, que interpretam praticamente todos os ecossistemas existentes como produtos da relação direta ou indireta entre os meios de produção (economia) e padrão das relações sociais das diversas comunidades humanas que habitam o planeta (Balée, 2006; Byron e Arnold, 1999; Brown e Lugo, 1990; Corlett, 1994; Dean, 1996; Fairhead e Leach, 1996; Miranda e Mattos, 1992; Redclift e Woodgate, 1988; Schwartzman et al., 2000). Fairhead e Leach (1996), em um estudo de populações pobres rurais do sudeste de Guiné (África), fazem uma releitura da paisagem local (um mosaico de savana e formações florestais) sob uma perspectiva cultural e histórica. Os autores rebatem a hipótese corrente (dentre leigos e acadêmicos) de que esse mosaico seria conseqüência de uma paisagem primordialmente florestal (relativamente homogênea) altamente modificada por uma intensa devastação causada pelas populações humanas que vinham habitando a região (Fairhead e Leach, 1996). Alternativamente, argumentam que o processo que ocorreu na região não foi o de uma predominante destruição, mas sim, o de construção de uma paisagem dentro da qual as manchas florestais existentes nada mais são do que produto de algumas das práticas de cultivo locais. Através do estabelecimento de condições de solo e regime de fogo favoráveis, os corredores de floresta são encorajados a se desenvolver. Uma vez estabelecidos, passam a constituir aspectos importantes da vida econômica, social e espiritual das populações humanas locais: eles barram o avanço do fogo; protegem os moradores de ventos fortes e do calor excessivo; são fonte conveniente de produtos florestais que atendem às necessidades cotidianas dos moradores, seja para alimentação, saúde, combustível, construção ou manufatura de equipamentos; são sítios adequados para atividades sociais e rituais; e em tempos de conflitos são centrais como locais de proteção, assentamento e fortificação. Dessa maneira, a forma e a 
distribuição das manchas de floresta não poderiam ser entendidas de maneira dissociada da história do processo de ocupação desses mesmos produtores rurais (Fairhead e Leach, 1996).

Com relação à Floresta Costeira Altântica, Dean (1996) argumenta que a sua história não seria simplesmente uma história natural, mas sim a da relação entre a floresta e o homem. Há pelo menos 11 mil anos que a maior parte dela, ou sua totalidade, vem sofrendo algum tipo de intervenção, seja a derrubada seletiva, o extrativismo ou a poluição dos rios (Dean, 1996). Dessa forma, seria razoável pensar toda a extensão dessa floresta tropical como um mosaico heterogêneo desde tempos muito antigos (Dean, 1996; Miranda e Mattos, 1992). Este mosaico seria definido não apenas no que concerne às variações ecossistêmicas naturais (decorrentes de diferenças climáticas, edáficas, geográficas e topográficas), mas no que se refere também a transformações antrópicas milenares (resultando em unidades de paisagem compostas por floresta secundária em diversos estágios de regeneração, áreas de cultivo, dentre outros) (Dean, 1996; Miranda e Mattos, 1992). Em termos estruturais, portanto, esse ecossistema não é um sistema estático nem estável, mas sim um ambiente dinâmico no qual perturbações em diferentes graus são comuns (Alcorn ,1995).

\subsection{As comunidades quilombolas}

Como é possível depreender das discussões anteriores, o Vale do Ribeira compõe um cenário dentro do qual preservação do meio natural e manutenção (e melhoria) da qualidade de vida das populações campesinas e indígenas são elementos chave. A seguir serão apresentados um breve histórico e uma caracterização preliminar dos pontos demográficos e sócio-econômicos de alguns dos atores dessa delicada relação, isto é, comunidades-alvo deste estudo (Sapatu, Pedro Cubas e São Pedro (Figura 3.1)). 


\subsection{Histórico}

\subsubsection{Sapatu}

A comunidade de Sapatu localiza-se ao longo das duas margens do Rio Ribeira do Iguape, por "aproximadamente 5 km" (RTC do ITESP de Sapatu, 2000, p. 30), e ao longo da Rodovia SP-165, que corta a comunidade ao meio. O bairro é subdivido em três sub-regiões principais: Cordas, Sapatu e Indaiatuba (RTC do ITESP de Sapatu, 2000).

Sob uma perspectiva histórica, Sapatu foi fundada por escravos foragidos pertencentes tanto a quilombos vizinhos quanto aos contingentes de negros libertos dos recrutamentos "para composição dos batalhões de combate para a Guerra do Paraguai" (RTC do ITESP de Sapatu, 2000, p. 31). Os negros libertos formaram, então, um contingente de pequenos produtores rurais, que procuraram terras férteis para exercer suas atividades. Foi então que, através de alianças matrimoniais (principalmente com o bairro de São Pedro), a população de Sapatu cresceu e se consolidou. Embora nenhum nome em especial seja lembrado pelos moradores de Sapatu, como principal fundador da comunidade (Andrade et al., 2000), a família Furquim é considerada uma das pioneiras da região. A população de Sapatu teve períodos de relativa tranqüilidade e estabilidade até meados 1950, quando o território, habitado predominantemente por populações negras claramente relacionadas ao histórico da escravidão, foi exposto a inserção de outros agentes não originários de remanescentes de quilombos (como grileiros e posseiros) (RTC do ITESP de Sapatu, 2000). Essa situação teve seu auge na década de 70, com a abertura de estradas como a que liga Eldorado a Iporanga e a BR-116. Dois nomes principais são relacionados a esse período crítico: o de Sebastião Domingues e o de Zé Capova (RTC do ITESP de Sapatu, 2000). Ambos utilizavam-se da força de persuasão física e retórica para desapropriar os moradores remanescentes de quilombos de suas terras (ou fazê-los vendê-las a preços baixíssimos) e utilizá-las em seu favor. Aos poucos essas propriedades foram passadas para a mão de terceiros, muitos dos quais ainda hoje estão estabelecidos na região com ou sem 
regularização definida. Isso atribuiu à região compreendida por Sapatu uma "malha fundiária complexa, marcada pela fragmentação e por uma ocupação irregular heterogênea bastante diferente da configuração espacial original” (RTC do ITESP de Sapatu, 2000, p.40). A retomada do território da Comunidade de Sapatu pelos remanescentes de quilombos iniciou-se em meados da década de 90, através de orientação de integrantes do Partido dos Trabalhadores (PT) e militantes do Movimento Negro Unificado (MNU), bem como o estímulo proporcionado pela "regularização das terras de quilombo abertas pela Constituição de 1988" (RTC do ITESP de Sapatu, 2000; RTC do ITESP de Pedro Cubas de Cima, 2003, p.30). Em 1997 foi fundada a Associação de Moradores de Quilombos, o que estabilizou significativamente a situação dos remanescentes.

Outro aspecto importante da comunidade deve-se ao fato da mesma se localizar ao longo das duas margens de um rio extremamente assoreado (resultado de intervenções antrópicas) e de grande porte - o Ribeira do Iguape - o que atribuiu à região um histórico bastante significativo de influência das enchentes promovidas por esse corpo d'água. Uma das enchentes de mais repercussão foi a de 1997, ocasião em que Sapatu foi gravemente atingida. A proximidade com o Rio Ribeira também estimulou o surgimento do Movimento de Ameaçados por Barragens (MOAB), que até hoje atua na região (RTC do ITESP de Sapatu, 2000).

Atualmente, a acessibilidade de Sapatu aos centros urbanos próximos, devido à SP-165, constitui um fator que vem impulsionando a produção de banana para comercialização e o aumento de atividades não-agrícolas para as famílias da região (como prestação de serviços para o governo local e atividades relacionadas ao turismo). O grau de diversificação de tais atividades, como resultado do fácil acesso proporcionado pela rodovia, é maior em Sapatu que nas demais comunidades do estudo.

\subsubsection{São Pedro}

Antigamente denominada "Barra de São Pedro", o atual bairro de São Pedro tem sido caracterizado historicamente como uma região de terras férteis para o 
plantio. Localiza-se às margens de um dos afluentes do Rio Ribeira do Iguape, e constituiu uma alternativa ao repovoamento do Vale do Ribeira logo após o declínio da mineração, que passou a ocorrer em lugares menos valorizados. Foi fundado por Bernardo Furquim, um africano que chegou ao Brasil aos 12 anos de idade e refugiou-se mais tarde na área hoje compreendida pela comunidade de São Pedro (Carvalho, 2006). Antes de sua chegada, porém, há relatos de outros moradores já instalados na região que, nessa ocasião, era conhecida por "Lavrinha". A interação entre os "ocupantes mais recentes e aqueles que os precederam (...) era baseado em políticas de aliança" (Andrade et al, 2000, p. 79). São Pedro foi, ainda, referência na "ampliação e consolidação da ocupação territorial" (Andrade et al 2000, p. 76) de "territórios historicamente significativos" (Andrade et al., 2000, p.77) para as comunidades negras da região do Médio Ribeira. Através de alianças com o bairro de Ivaporanduva, São Pedro forneceu, nas década de 50 e 60 do século XIX, "mulheres que possibilitaram a fixação de negros perseguidos em terras próximos" (Andrade et al., 2000, p.77).

Assim como em Sapatu, a partir de 1950 o território referente a São Pedro, habitado por populações negras, foi exposto a inserção de outros agentes não remanescentes de quilombos (como grileiros e posseiros) (RTC do ITESP de Pedro Cubas de Cima, 2003). Esse processo atingiu seu auge na década de 70, período em que muitos dos moradores mais antigos da região cederam à pressão desses novos agentes e partiram para núcleos urbanos mais próximos ou venderam suas terras e continuaram a trabalhar nas mesmas apenas como empregados. Desse modo, muitas das atividades, geografia e modo de vida local foram modificados. $O$ crescimento da extração e venda do palmito, que também se iniciou nessa mesma época, aprofundou ainda mais esse processo (RTC do ITESP de Pedro Cubas de Cima, 2003). A atividade extrativa foi também estimulada pela restrição a abertura de roças através da criação de leis ambientais e do estabelecimento de Unidades de Conservação na região (RTC do ITESP de Pedro Cubas de Cima, 2003). A retomada do território da comunidade de São Pedro pelos remanescentes de quilombos iniciou-se no fim da década de 80 e na década de 90, "com a regularização das terras de quilombo abertas pela Constituição de 1988" (RTC do ITESP de Pedro Cubas de Cima, 2003, p. 30). Com boas expectativas de titulação do território e melhoria da qualidade de vida na região, os antigos habitantes de São 
Pedro foram aos poucos retornando e formando resistência contra os posseiros e grileiros que haviam se instalado no local recentemente. A criação da Associação de Moradores de Quilombos (no final da década de 90) estabilizou significativamente a situação dos remanescentes.

\subsubsection{Pedro Cubas}

A Comunidade Quilombola de Pedro Cubas possui duas grandes subdivisões: a Vila de Santa Catarina, núcleo "urbano" que se localiza a cerca de 10 km do Rio Ribeira do Iguape; e Pedro Cubas de Cima, região ainda mais afastada do Rio Ribeira, que é composta por famílias que vivem ao longo de outros afluentes do Rio Pedro Cubas, em localidades como Cerrado Grande, Penteado, Bromado, Boqueirão/Pedrinha, Itopava, Rio dos Peixes, Areado, Areadinho e Braço Grande (RTC do ITESP de Pedro Cubas de Cima, 2003). A Vila está próxima à foz do Rio Ivaporanduvinha, que deságua no rio que dá nome a região, o Rio Pedro Cubas (RTC do ITESP de Pedro Cubas de Cima, 2003).

A origem da comunidade é relacionada ao escravo foragido Gregório Marinho, que escapou de uma fazenda da região (Andrade et al., 2000) e se instalou na "cabeceira do rio", que mais tarde ficou conhecida como "praia do Gregório Marinho" (Andrade et al, 2000:79). Mais especificamente, a Vila de Santa Catarina se formou através da aglomeração de pessoas que vieram morar em "terrenos doados pela Santa" (RTC do ITESP de Pedro Cubas de Cima, 2003, p. 14), expressão atribuída ao fato da antiga moradora (Edwiges Maria da Conceição) haver cedido seu terreno à Santa Catarina. Muitos possuem residência na Vila e em regiões mais longínquas, evidenciando o papel desse centro urbano na consolidação dos laços sociais da Comunidade. Através de alianças matrimoniais com o "bairro" de Ivaporanduva, a população de Pedro Cubas cresceu e se consolidou. As alianças matrimoniais, tanto entre membros da população do bairro quanto com indivíduos de outros bairros negros contemporâneos, eram uma forma de firmar relações de "amizade e de reciprocidade econômica e social" (RTC do ITESP de Pedro Cubas de Cima, 2003, p. 31). Inicialmente, os moradores habitavam sítios, que agregavam "a família e a 
parentela" (RTC do ITESP de Pedro Cubas de Cima, 2003, p. 14) e se interconectavam através de trilhas.

De maneira semelhante à descrita para as outras Comunidades constituintes deste estudo, a partir de 1950 o território referente a Pedro Cubas foi exposto a inserção de outros agentes não remanescentes de quilombos (como grileiros e posseiros) (RTC do ITESP de Pedro Cubas de Cima, 2003). A retomada do território da Comunidade de Pedro Cubas, pelos remanescentes de quilombos, iniciou-se no fim da década de 80 e na década de 90, "com a regularização das terras de quilombo abertas pela Constituição de 1988" (RTC do ITESP de Pedro Cubas de Cima, 2003 p.30). A criação da Associação de Moradores de Quilombos (no final da década de 90) estabilizou significativamente a situação dos remanescentes, embora a titulação das terras para a Comunidade como um todo ainda esteja em processo de conclusão (apenas parte do bairro está titulado).

\subsubsection{Aspectos demográficos e socioeconômicos}

A população total em Sapatu reportada no trabalho de Pedroso-Júnior e colaboradores (2008b) é de 292 indivíduos, pertencentes a 75 unidades domésticas $(\mathrm{UD})^{7}$, uma média de 4 indivíduos por UD. Desse total, 54 são chefiadas pelo casal e 21 por uma pessoa, independente do seu estado civil. Os chefes de família foram considerados aqueles indivíduos que possuíam a propriedade da terra onde estava estabelecida a Unidade doméstica e/ou eram responsáveis pela maior parte do sustento familiar (Pedroso-Júnior, 2008). Os 129 chefes de família possuem 310 filhos vivos, sendo um pouco menos da metade destes (133) co-residentes (Tabela 3.1)

A população total de São Pedro foi de 123 indivíduos, pertencentes a 28 unidades domésticas, configurando uma média de aproximadamente 4 indivíduos

\footnotetext{
${ }^{7}$ A unidade doméstica (UD) é o núcleo produtivo da agricultura familiar nos trópicos, uma categoria sócio-espacial onde as relações familiares e produtivas articulam-se em torna da referencia geográfica da casa. Sabe-se que as unidades domésticas podem ser constituídas por mais de uma unidade familiar. Ou seja, o espaço físico da residência (unidade doméstica) pode conter mais de uma família nuclear (unidade familiar), que geralmente é composta por um casal e seus filhos ou por um dos cônjuges e seus filhos (Pedroso-Júnior et al 2008b).
} 
por UD (Pedroso-Júnior, 2008; Pedroso-Júnior et al., 2008b). Dessas, 17 são chefiadas pelo casal e 11 por uma pessoa. Os 45 chefes de família possuem 120 filhos vivos, sendo praticamente metade destes (63) co-residentes (Pedroso-Júnior, 2008; Pedroso-Júnior et al., 2008b) (Tabela 1)

Em Pedro Cubas, foram reportados 269 indivíduos, pertencentes a 68 unidades domésticas, ou seja, a mesma média de indivíduos por UD das Comunidades anteriores (Pedroso-Júnior, 2008; Pedroso-Júnior et al., 2008b). Dessas, 44 são chefiadas pelo casal e 24 por uma pessoa. Os 112 chefes de família possuem 263 filhos vivos, sendo um pouco menos da metade destes (121) coresidentes (Tabela 3.1 )

Tabela 3.1: Alguns aspectos demográficos das comunidades quilombolas de Pedro Cubas, São Pedro e Sapatu.

\begin{tabular}{lccc}
\hline DEMOGRAFIA & Pedro Cubas & S. Pedro & Sapatu \\
\hline Unidades domésticas & 68 & 28 & 75 \\
Média de moradores por UD & 3,9 & 4,4 & 3,9 \\
Chefes de família (casal) & 88 & 34 & 108 \\
Chefes de família (uma pessoa) & 24 & 11 & 21 \\
Filhos vivos & 263 & 120 & 310 \\
Filhos co-residentes & 121 & 63 & 133 \\
Outros membros co-residentes & 36 & 15 & 30 \\
Total & 269 & 123 & 292 \\
\hline
\end{tabular}

Fonte: Pedroso-Júnior 2008

O padrão etário das comunidades estudadas é muito semelhante ao encontrado em outras populações pobres rurais do país: um elevado número de crianças e jovens, e uma baixa acentuada na população adulta e idosa (IBGE, 2000; Pedroso-Júnior, 2008). Essa configuração sugere também um número expressivo de jovens adultos que emigram para centros regionais próximos, como a cidade de Registro, ou de grandes cidades como Santos e São Paulo, em busca de melhores oportunidades e condições de vida (Pedroso-Júnior, 2008; Pedroso-Júnior et al., 2008b).

O número de analfabetos na comunidade de Sapatu chega a $40 \%$ entre os chefes de família. Metade dos chefes de família é representada basicamente por 
pessoas com o ensino fundamental incompleto, geralmente interrompidos na 4⿳亠丷a série (Figura 3.2) (Pedroso-Júnior, 2008; Pedroso-Júnior et al., 2008b). Entre os filhos coresidentes, que totalizam 133 indivíduos, 71 são estudantes e 24 auxiliam os pais na roça.

Em São Pedro, o número de analfabetos na comunidade chega a um quarto dentre os chefes de família (Pedroso-Júnior, 2008; Pedroso-Júnior et al., 2008b). Assim como para Sapatu, metade dos chefes de família de São Pedro é representada basicamente por pessoas com o ensino fundamental incompleto, geralmente interrompidos na 4⿳亠丷a série (Pedroso-Júnior, 2008; Pedroso-Júnior et al., 2008b) (Figura 3.2). Entre os filhos co-residentes, que totalizam 63 indivíduos, 41 são estudantes e 8 apenas auxiliam os pais na roça (Pedroso-Júnior, 2008; Pedroso-Júnior et al., 2008b).

Em Pedro Cubas o número de chefes de família analfabetos chega a pouco mais de um terço do total (Figura 3.2) (Pedroso-Júnior, 2008; Pedroso-Júnior et al., 2008b). Metade dos chefes de família seguem o mesmo padrão observado nas comunidades anteriormente descritas. Dentre os filhos co-residentes, que totalizam 121 indivíduos, 81 são estudantes e 8 auxiliam os pais na roça (Pedroso-Júnior, 2008; Pedroso-Júnior et al., 2008b).

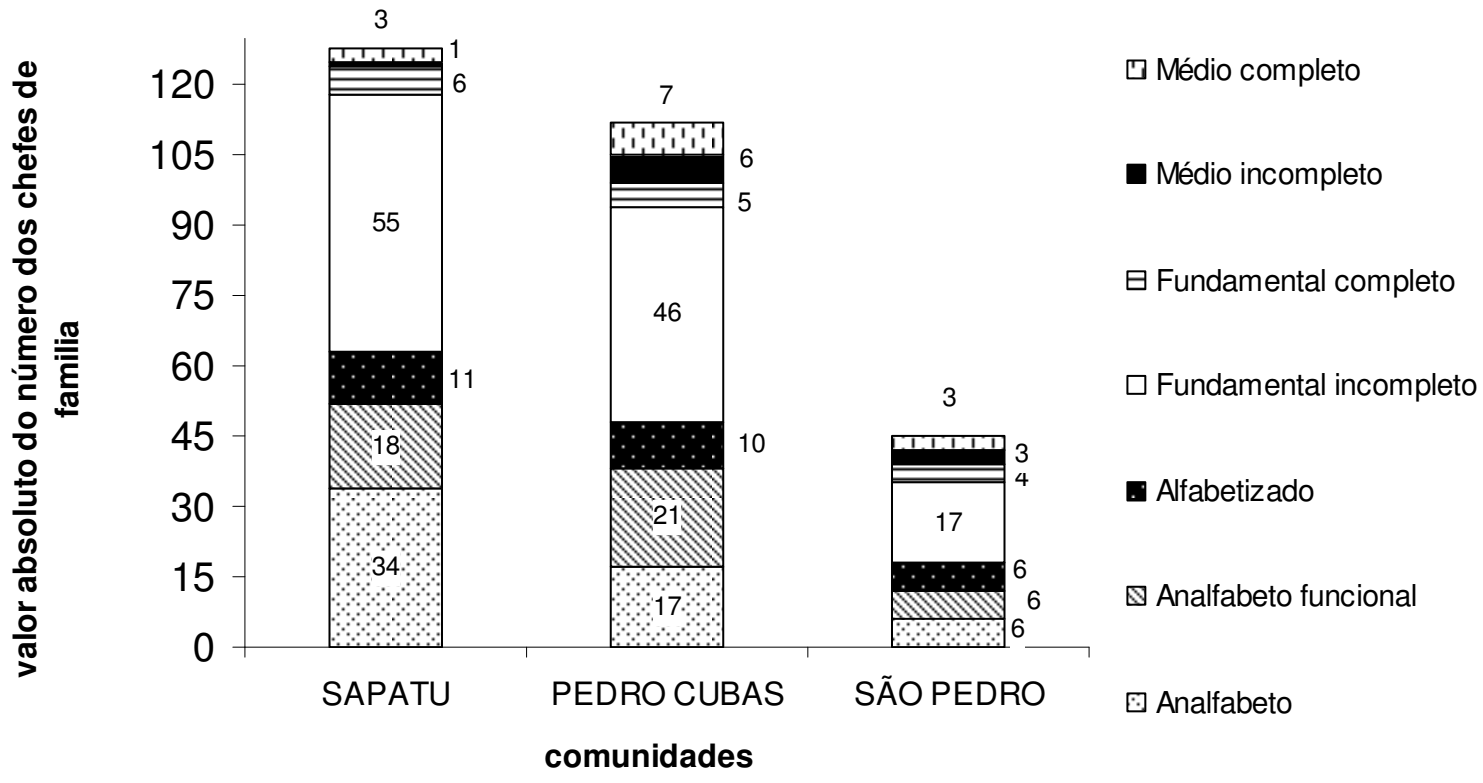

Figura 3.2: escolaridade dos chefes de família nas comunidades quilombolas de Sapatu, Pedro Cubas e São Pedro (Fonte: Pedroso-Júnior 2008) 
Com relação às principais profissões dos chefes de família, em Sapatu cerca de $60 \%$ dos chefes de família são predominantemente lavradores (Figura 3.3). Os demais dividem-se principalmente entre aposentados, pensionistas, donas-de-casa e, em menor número, por diaristas de roça e outros serviços temporários, como frentes de trabalho e prestação de serviços para o governo local (Pedroso-Júnior, 2008; Pedroso-Júnior et al., 2008b).

Em São Pedro, cerca de 90 \% dos chefes de família são lavradores. Os demais dividem-se principalmente entre aposentados, pensionistas e donas-de-casa (Figura 3.3) (Pedroso-Júnior, 2008; Pedroso-Júnior et al., 2008b).

Em Pedro Cubas, cerca de $70 \%$ dos chefes de família são lavradores, enquanto o restante se divide principalmente entre diaristas de roça, aposentados, pensionistas, donas-de-casa e, em menor número, por outros serviços temporários (Figura 3.3). (Pedroso-Júnior, 2008; Pedroso-Júnior et al., 2008b).

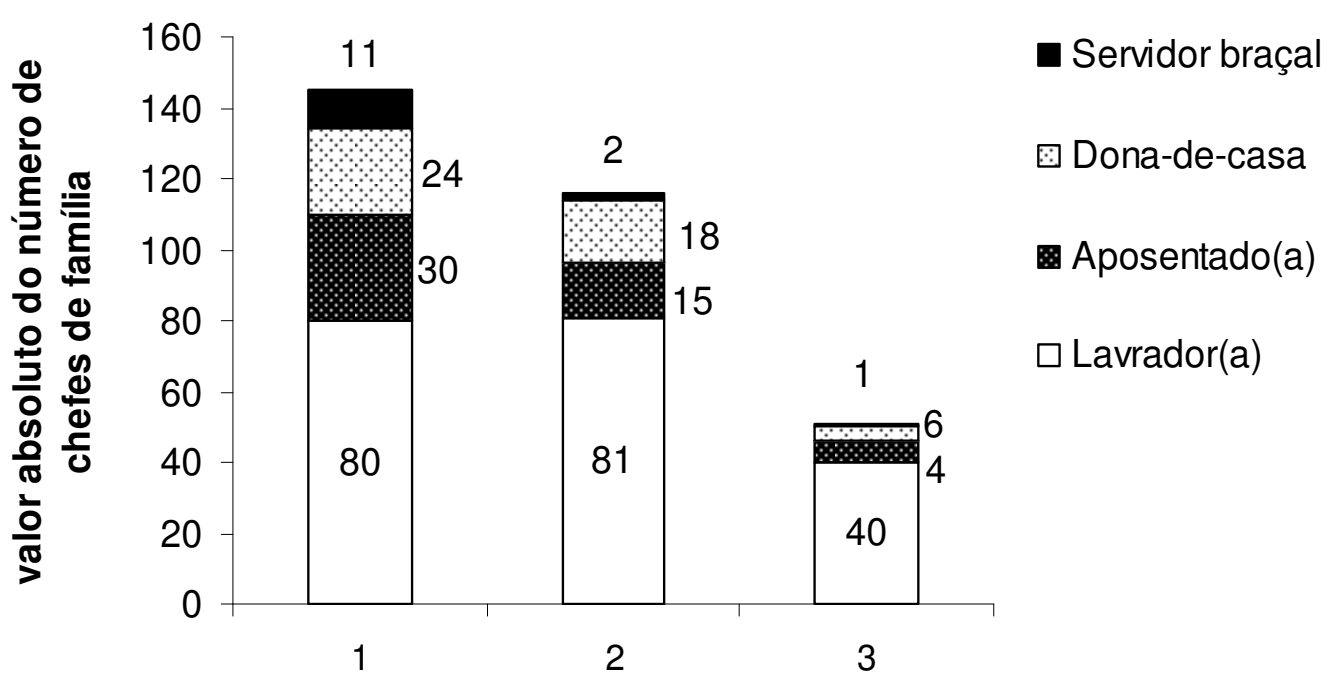

comunidades

Figura 3.3: principais profissões dos chefes de família nas comunidades quilombolas de Sapatu, Pedro Cubas e São Pedro (Fonte: Pedroso-Júnior 2008)

Com relação às principais fontes de renda das famílias de Sapatu (Figura 3.4), 62,7\% $(n=47)$ das unidades domésticas contam com o recebimento de benefícios do governo (como aposentadorias, bolsas - família e escola) (PedrosoJúnior, 2008; Pedroso-Júnior et al., 2008b). Dentre estas, 9 possuem o bolsa-escola 
como única fonte estável de renda familiar (Pedroso-Júnior, 2008; Pedroso-Júnior et al., 2008b). As outras fontes de renda distribuem-se entre a venda de banana e de outros produtos agrícolas, totalizando 36\% $(n=27)$ das UDs, 17,3\% $(n=13)$ trabalhos esporádicos como diaristas $14,17 \%(n=11)$ prestação de serviços diversos e 6,7\% $(\mathrm{n}=5)$ artesanato (Pedroso-Júnior, 2008; Pedroso-Júnior et al., 2008b). Apenas 2,7\% $(\mathrm{n}=2)$ das famílias em Sapatu relataram a extração do palmito Jussara (Euterpe Edulis) como parte de sua fonte de renda (Pedroso-Júnior, 2008; Pedroso-Júnior et al., 2008b).

Em São Pedro, 37\% $(n=10)$ das unidades domésticas possuem como principal fonte de renda a aposentadoria, e cerca de $41 \%(n=11)$ recebem bolsaescola e/ou bolsa-família (figura 4) (Pedroso-Júnior, 2008; Pedroso-Júnior et al., 2008b). 63\% ( $n=17)$ complementam sua renda através de atividades extrativistas no caso, a retirada do palmito Jussara (Euterpe edulis), e outros $15 \%(n=4)$ através da venda de produtos agrícolas.

Em Pedro Cubas, 25,4\% $(n=17)$ das unidades domésticas possui como principal fonte de renda a aposentadoria, 20,9\% $(n=20)$ recebem bolsa-escola ou bolsa-família (Pedroso-Júnior, 2008; Pedroso-Júnior et al., 2008b) (figura 4). Há a complementação de renda através de trabalhos esporádicos como diárias em roça, totalizando $31,3 \%(n=21) .20,9 \%(n=14)$ das UDs têm como uma das fontes de renda da família a venda de produtos agrícolas, $16,4 \%(n=11)$ a prestação de serviços diversos e 30\% $(n=20)$ o extrativismo vegetal (Pedroso-Júnior, 2008; Pedroso-Júnior et al., 2008b). 


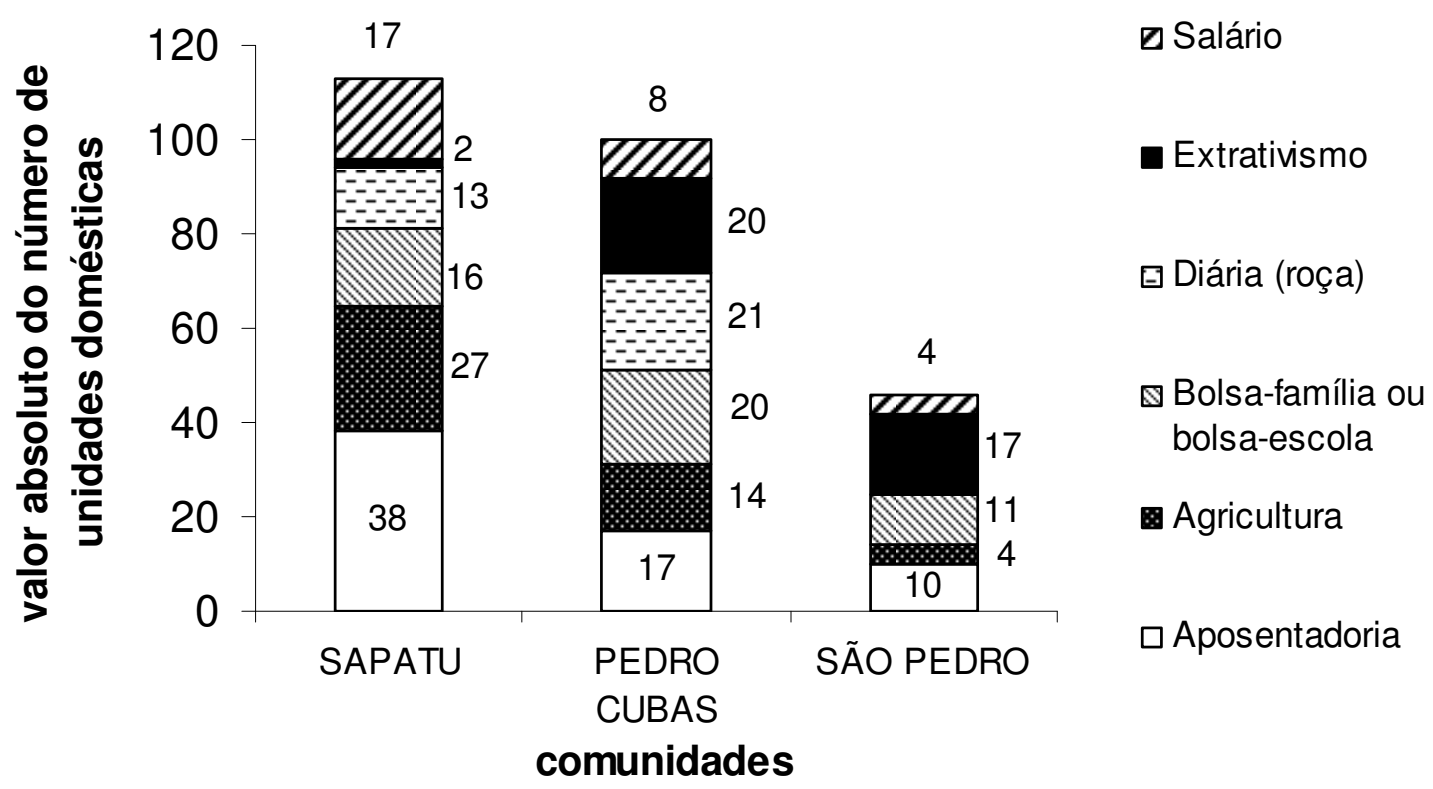

Figura 3.4: principais fontes de renda famílias das comunidades quilombolas de Sapatu, Pedro Cubas e São Pedro (Fonte Pedroso-Júnior 2008)

\subsection{Metodologia de pesquisa}

\subsubsection{Embasamento teórico-metodológico}

Este estudo congrega tanto dados biofísicos quanto socioeconômicos das populações estudadas. Tal congregação metodológica é ideal para a investigação de unidades sócio-ambientais de natureza multifuncional como os sistemas agroflorestais complexos, no caso, os jardins-quintal (Hammersley e Atkinson, 1995). Desta forma, e sabendo que a coleta e análise dos dados deste estudo se realizaram baseadas em preceitos estabelecidos pelos métodos etnográficos e etnobotânicos, ele é construído sobre duas bases analíticas: uma qualitativa e etnográfica e a outra quantitativa e sistemática (Zent, 1996; Peters,1996). As análises qualitativas, por raramente possuírem um padrão ou delineamentos previsíveis, são muitas vezes negligenciadas (Hammersley e Atkinson, 1995). Contudo, não há outra abordagem mais apropriada para a compreensão da 
subjetividade e contingência dos sujeitos que estão por trás das práticas sociais. Sendo assim, a abordagem etnográfica permeou todas as etapas desta pesquisa, com ênfase em entrevistas informais e não-estruturadas. Com isso, pretendeu-se preencher possíveis lacunas deixadas pelos de natureza mais quantitativa e estruturada. (Bernard, 1995; Hammersley e Atkinson, 1995).

As unidades de análise deste estudo foram o indivíduo e a unidade doméstica, já que podem ser considerados os elementos mais significativos de produção e reprodução das estruturas sociais (econômicas, simbólicas, políticas) (Murrieta e WinklerPrins, 2003). Segundo Netting (1993), a unidade domestica é uma unidade de produção e de consumo significativa, freqüentemente definida por residência comum, reprodução e socialização, e transmissão inter-geração de direitos e meios de produção (Netting, 1993). A família elementar (no caso deste estudo, representada pela UD) aparece ainda hoje como unidade fundamental de produção e, em larga medida, também como unidade de consumo (Queiroz, 2006). As mulheres foram as informantes-chave deste projeto, já que são amplamente reconhecidas como principais mantenedoras dos jardins-quintal (Brito e Coelho, 2000; Figueiredo et al., 1997; Greenberg, 1996; Howard, 2003; Murrieta e Wrinklerprins, 2003; Tsegaye, 1997).

\subsubsection{Coleta de dados}

Para a produção de um perfil sócio-econômico e compreenção do cenário socioambiental regional foram aplicados questionários sócio-econômicos e demográficos em nove bairros remanescentes de quilombo (André Lopes, Galvão, Ivaporunduva, Maria Rosa, Nhunguara, Pedro Cubas, Pilões, São Pedro e Sapatu). Essa primeira fase dividiu-se em 11 etapas de campo, realizadas entre outubro de 2003 e abril de 2005, coordenadas inicialmente pelo Frof. Dr. Rui Sérgio Sereni Murrieta e posteriormente pelo Dr. Nelson Novaes Pedroso-Júnior. A equipe de coleta desses dados censitários contou com 4 alunos de graduação e 3 alunos de pós-graduação. A orientação geral foi do Prof. Dr. Rui Murrieta. Com isso, um cenário geral foi alinhavado a respeito dos ecossistemas agroflorestais locais, bem 
como uma caracterização regional sócio-econômica que favoreceu a escolha e seleção destas três comunidades.

O trabalho de campo deste estudo foi desenvolvido entre abril de $2007 \mathrm{e}$ fevereiro de 2009. Foram amostrados 30 jardins-quintal em Sapatu (40\% do total de 75 UDs da comunidade) 27 em Pedro Cubas (39,7\% do total de 68 UDs da comunidade) e 14 em São Pedro (50\% do total de 28 UDs da comunidade), totalizando 71 entrevistas realizadas. Todas as famílias selecionadas acordaram oralmente em participar do estudo, sendo o informante-chave sempre procedente da região, assim como seus pais. Esses critérios objetivaram a escolha de famílias que estavam incluídas no processo de reconhecimento público da identidade quilombola, e que, em conseqüência do tempo de residência no local, faziam parte da história agrícola do bairro.

A primeira etapa de campo contemplou conversa inicial junto às famílias previamente selecionadas, uma breve apresentação dos objetivos da pesquisa e um delineamento geral do conteúdo das entrevistas. Nessa mesma oportunidade era marcado o dia da entrevista, segundo a disponibilidade dos chefes de família (era sempre requisitada a presença preferencial do maior responsável pelo espaço referente ao jardim-quintal). A partir da segunda etapa de campo iniciou-se a coleta de dados propriamente dita. A coleta de dados era divida em quatro momentos principais: a primeira objetivava uma investigação da organização do trabalho familiar voltado para os jardins-quintal, das técnicas e dificuldades de manejo do espaço e de alguns elementos do histórico da UD. Nesse primeiro momento, foram realizadas entrevistas semi-estruturadas (Apêndice $A$ ), gravadas em mini-gravador portátil. As entrevistas do tipo semi-estruturadas, por serem desprovidas de roteiros estritos de investigação, são extremamente úteis para fornecer um panorama geral do objeto de estudo, e abrir precedentes para o surgimento de novos temas que auxiliem na elucidação das questões propostas na pesquisa (Bernard, 1995; Hammersley e Atkinson, 1995; Oliveira, 1996; Vietler, 2002). O segundo momento da coleta de dados referiu-se à quantificação da composição e diversidade dos jardins-quintal, sendo que, para tal, foram utilizados questionários abertos também gravados em mini-gravador portátil (Apêndice B). A pesquisadora era acompanhada pelo informante-chave por todo o espaço referente ao jardim-quintal da unidade doméstica, e sobre cada etnovariedade encontrada eram feitas as perguntas 
detalhadas no Anexo B. No terceiro momento eram tiradas fotografias em máquina digital das variedades listadas. Por fim, eram realizados perfis da vegetação e croquis do espaço referente à UD e a área de cultivo adjacente (Apêndice $\mathrm{C}$ ). Nos últimos retornos a campo foram coletadas as etnovariedades que não puderam ser identificadas apenas através do registro fotográfico. A identificação taxonômica foi conduzida utilizando-se a literatura disponível (Lorenzi e Souza, 2002; Souza e Lorenzi, 2005; Lorenzi e Matos, 2002) e o auxílio de um profissional taxonomista do Instituto de Botânica do Estado de São Paulo. Adicionalmente, outros procedimentos eventuais de pesquisa foram adotados durante o trabalho de campo, como a observação direta durante o convívio informal com as famílias e registros em diário de campo. As entrevistas foram transcritas e arquivadas em arquivos de Microsoft Word.

\subsubsection{Análise de dados}

As informações de natureza qualitativa (provenientes das entrevistas semiestruturadas e das conversas informais) passaram por uma reorganização em categorias analíticas menos abrangentes. Essa reorganização facilitou comparações e potencializou a percepção de possíveis tendências dentro das abordagens menos redutíveis deste estudo (Hammersley e Atkinson, 1995) (Apêndices A e B). Adicionalmente, foi realizada uma conjugação de parte dos dados provenientes dos censos demográfico e socioeconômico (Pedroso-Júnior, 2008; Pedroso-Júnior et al., 2008b) com parte dos dados coletados neste estudo (referentes ao subsistema jardim-quintal). Os censos serviram como base para a seleção de indicadores indiretos da situação socioeconômica das unidades domésticas das comunidades quilombolas participantes desse estudo. Os indicadores utilizados foram: número de eletrodomésticos presentes na unidade doméstica; nível de escolaridade máximo dentre os chefes de família; e presença ou ausência de um papel de liderança local na família elementar (Apêndice D). A escolha dos dois primeiros fatores citados se deu porque os mesmos são indicadores econômicos e sociais de domicílios de eficiência comprovada, amplamente utilizados por institutos de pesquisa nacionais 
(como o IBGE - Instituto Brasileiro de Geografia e Estatística) (IBGE, 2006). E, ao mesmo tempo, mostraram-se bem apropriados para definir as diferenças econômicas e sociais qualitativas observadas em campo entre as unidades domésticas quilombolas investigadas ao longo de todo o período de pesquisa (2004 a 2009). A inclusão do último fator (papel relevante ou não da família nas tomadas de decisão locais) baseou-se apenas em uma percepção consolidada em experiências vivenciadas durante as etapas de campo, e que pressupõe tratar-se de um elemento significativo no potencial de mobilidade social. De maneira geral, os líderes comunitários em questão possuem várias atividades relacionadas à organização política e econômica da comunidade (como presidência ou vicepresidência da Associação de Moradores de Quilombos, coordenação de projetos financiados por ONGs ou órgãos do governo, participação freqüente em reuniões de moradores, dentre outros), e têm um papel chave nas tomadas de decisão referentes a esses dois âmbitos.

Foi estabelecido um valor máximo e um valor mínimo padrão para os três fatores selecionados, sendo eles 1 e 0 , respectivamente. Dessa maneira, parte-se do pressuposto que esses três indicadores possuem o mesmo peso na definição do status socioeconômico das unidades domesticas quilombolas aqui estudadas. No caso do nível de escolaridade foi atribuído um valor equivalente para cada nível: analfabetos com valor 0 ; fundamental incompleto com valor 0,2 ; fundamental completo com valor 0,4 ; médio incompleto com valor 0,6 ; médio completo com valor 0,8; e superior incompleto com valor 1 (Apêndice D). Para o número de eletrodomésticos, que variaram entre 0 e 8 aparelhos dentre as 71 unidades domésticas, os valores correspondentes na elaboração do índice foram assim atribuídos: um eletrodoméstico $=0,125$; dois eletrodomésticos $=0,25$; até o extremo apresentado dentre as UDs, de 8 eletrodomésticos $=1$.

\subsubsection{Análise estatística de dados}

A análise exploratória dos dados foi realizada através da utilização da estatística descritiva. Dessa maneira, pretendeu-se avaliar de maneira prévia e 
cuidadosa a existência ou ausência de padrões de comportamento com relação aos conjuntos de dados levantados neste trabalho. A estatística descritiva proporciona ferramentas extremamente adequadas para estudos de natureza qualitativa, como este.

Quando conveniente, foram aplicados testes de hipótese como o teste de normalidade de Anderson-Darling, a Análise de Variância simples (ANOVA) e o teste de comparação de medianas Kruskal-Wallis. Dessa forma, foi possível realizar inferências estatísticas mais conclusivas.

A estatística de Anderson Darling é uma mensuração do quão os pontos da distribuição estão ajustados a uma reta traçada em papel de probabilidade. Neste teste é atribuído um peso maior aos pontos que estão nas caudas da distribuição. A hipótese nula testada declara que a distribuição é normal, enquanto que, a hipótese alternativa declara o contrário, isto é: a distribuição investigada é não normal. $O$ programa MINITAB usa a estatística Anderson Darling ajustada, porque os cálculos variam quando um número diferente de pontos são usados para compor a distribuição. Este é justamente o caso desta pesquisa, que trabalhou com um número amostral (unidades domésticas investigadas) variável em cada comunidade quilombola estudada (como reportado na seção anterior).

O teste de homogeneidade de variância foi aplicado porque, se cada uma das comunidades aqui estudadas apresentarem variâncias estatisticamente iguais, a variância global das três comunidades representaria uma estimativa de erro mais confiável, porque seria estimado com um número de graus de liberdade maior (no caso, a soma do número de graus de liberdade da estimativa das variâncias individuais). Isso proporcionaria uma base comparativa mais confiável (Box, Hunter e Hunter, 2005). Por este motivo este teste foi realizado antes da aplicação da ANOVA.

A Análise de Variância um fator (One-Way) foi aplicada ao conjunto de dados que apresentou distribuição normal (diversidade de etnovariedades por unidade doméstica), sendo utilizado para investigar a existência de diferença estatisticamente significativa entre as comunidades estudadas neste trabalho, com relação a este fator (comunidades). Dessa forma, a hipótese nula avaliada foi que e que as médias de cada comunidade são estatisticamente iguais (no caso, Sapatu, Pedro Cubas e São Pedro) (Madrigal, 1998). Caso seja validada essa hipótese, pode ser assumido 
que a variação intra-comunitária da diversidade de etnovariedades por unidade doméstica é de mesma ordem da existente entre as comunidades. Por outro lado, se a hipótese nula for rejeitada, assume-se então que os objetos do conjunto de dados analisado em pelo menos uma das comunidades quilombola têm maior similaridade entre si do que com relação aos objetos da outra comunidade.

Considerando a distribuição não-normal dos demais conjuntos de dados, foi adotada uma alternativa à Análise de Variância one-way: o teste não-paramétrico de comparação de medianas de Kruskal-Wallis. Trata-se de uma avaliação estatística que é robusta a não normalidade das distribuições originais (Madrigal, 1998; Box et al., 2005). De maneira semelhante à ANOVA, o Kruskal-Wallis também avalia diferenças entre grupos, mas, nesse caso, há uma classificação prévia dos dados (rank), antes de ser calculada a estatística do teste, que, como citado, utiliza as medianas dos conjuntos de dados ao invés da média (como acontece na ANOVA).

Por fim, foi utilizada nesta pesquisa uma análise exploratória de dados através de ferramentas estatísticas multivariadas, para avaliar a relação entre possíveis diferenças socioeconômicas entre as unidades domésticas quilombolas aqui referidas. O método aqui empregado foi 0 da análise de agrupamento hierárquico, que tem por finalidade separar um grupo original de observações em vários subgrupos (formando uma estrutura classificatória hierárquica (Lewinshon e Prado, 2006). Os objetos são, dessa forma, agrupados por um processo que se repete em vários níveis, sendo estabelecido um dendograma. O algorítmo de agrupamento utilizado foi o de Distância Euclidiana Padronizada, que mede a distância entre os grupos através da média (simples ou ponderada). O método de aglomeração utilizado foi o de média aritmética não ponderada (UPGMA). Neste método, a distância entre dois grupos é a média da distância entre uma observação em um grupo e uma observação em outro grupo. O critério da Média dos Grupos evita valores extremos, utilizando como critério de agregação a distância mínima entre todas as unidades domésticas de um mesmo grupo (Reis, 2001). 


\section{CAPÍTULO 4}

RESULTADOS

\subsection{Composição florística}

Com relação à composição florística dos jardins-quintal, foi quantificado um total de 520 etnovariedades distintas (ou seja, nomeadas em campo e/ou identificadas posteriormente - mesmo sem a indicação de uma denominação local pelo informante em campo) considerando as 71 UDs visitadas nas comunidades quilombolas referidas (Tabela 8). Destas, 86,53\% $(n=450)$ foram denominadas pelo informante em campo e 13,46\% ( $n=70)$ foram identificadas posteriormente (ao nível mínimo da família biológica) mesmo não possuindo uma denominação local associada (Apêndice E).

Em Sapatu foram reconhecidas e nomeadas um total de 365 etnovariedades distintas, em Pedro Cubas, 258 e em São Pedro, 247 etnovariedades distintas (Tabela 4.1). O número médio da diversidade de etnovariedades por jardim-quintal foi de 40,56 para Sapatu, 32,22 para Pedro Cubas e 44,28 para São Pedro (Tabela 4.1). A média para as 71 UD visitadas foi de 37,35 (Tabela 4.1). A diversidade de etnovariedades por jardim-quintal (Apêndice E) segue uma distribuição normal (Figura 4.1), segundo teste de normalidade de Anderson Darling (cuja hipótese nula declara que a distribuição é normal e a hipótese alternativa declara o contrário). 0 gráfico da Figura 4.1 mostra como os pontos de distribuição (vermelho) dos dados referentes a diversidade de etnovariedades por UD estão quase alinhados a reta (azul) que representa a tendência a distribuição normal. 
Tabela 4.1: caracterização florística dos jardins-quintal das comunidades quilombolas de Sapatu, Pedro Cubas e São Pedro (diversidade de etnovariedades para $n$ total de cada comunidade e por jardim-quintal de cada UD).

\begin{tabular}{lccc} 
Comunidade & UDs estudadas & diversidade por \\
\hline Sapatu & 30 & 365 & UD \\
Pedro Cubas & 27 & 258 & 40,56 \\
São Pedro & 14 & 247 & 30,22 \\
Total & 71 & 520 & 44,28 \\
\hline
\end{tabular}

*considerando apenas as etnovariedades nomeadas em campo e/ou identificadas posteriormente mesmo sem a indicação de uma denominação local pelo informante em campo.

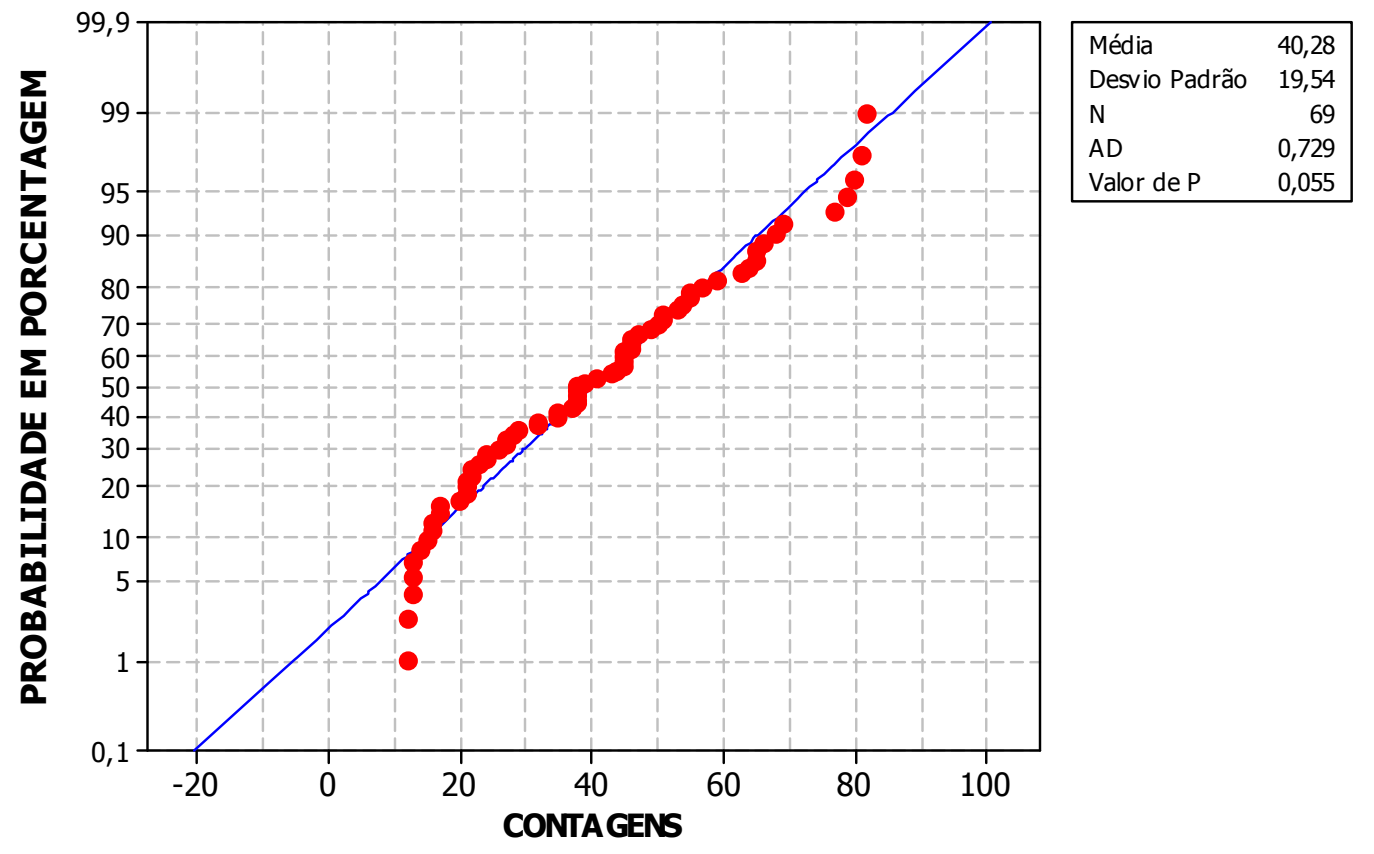

Figura 4.1: teste de normalidade de Anderson Darling relativo à diversidade de etnovariedades por jardim-quintal considerando as comunidades de Sapatu, Pedro Cubas e São Pedro $(n=71)$

\footnotetext{
${ }^{8}$ Em ecologia a diversidade é entendida, de maneira geral, como o número de táxons presentes em uma área ou região específica (Odum 2001), podendo ser medida em diversos níveis espaciais (local, regional, global). No caso deste estudo, "diversidade" se refere aos tipos distintos de etnovariedades presentes em um determinado jardim-quintal ou na somatória de jardins-quintal estudados em alguma das comunidades quilombolas pesquisadas. Ou seja, é uma medida distinta do que se chama aqui de "abundância", que designa ao numero de ocorrências de uma mesma etnovariedade em UDs distintas.
} 
Uma análise superficial da distribuição da diversidade de etnovariedades por jardim-quintal em cada comunidade, revelado pelas Figuras 4.2, 4.3 e 4.4, traz algumas informações relevantes. $O$ teste de igualdade de variâncias para esse parâmetro revelou que as três comunidades possuem variâncias estatisticamente iguais, indicado pela estatística do teste, isto é: Testes $\mathrm{F}$ com valores de $\mathrm{p}$ maiores do que o nível de significância estabelecido $(0,05)$ para a comparação das variâncias duas a duas. Os valores de p 0,55; 0,88 e 0,77 estão indicados nas Figuras 4.2, 4.3 e 4.4. Os intervalos de confiança de Bonferroni $95 \%$ também indicaram a mesma tendência. Elas possuem, portanto, a mesma homogeneidade na distribuição da diversidade de etnovariedades cultivadas no espaço do jardim-quintal entre as UD. Como se trata de uma distribuição normal, são os valores resultantes do Teste $F$ que devem ser considerados.
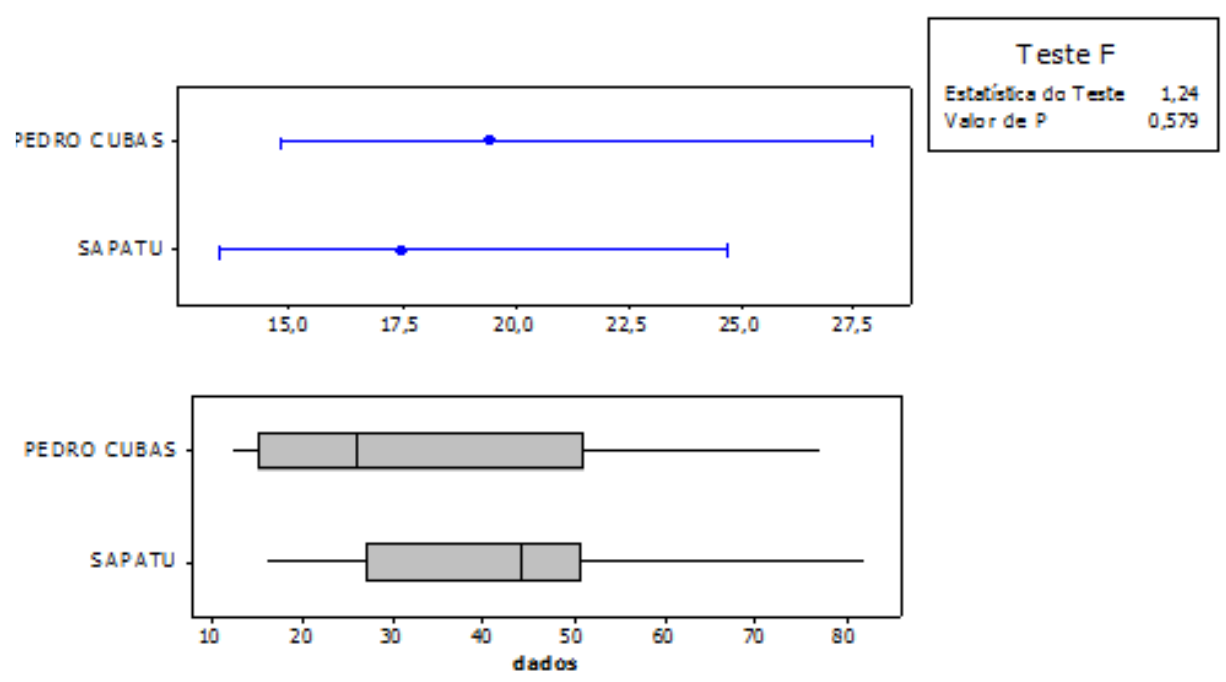

Figura 4.2: teste de Igualdade de Variâncias diversidade de etnovariedades por jardim. quintal entre as comunidades quilombolas de Sapatu e Pedro Cubas 

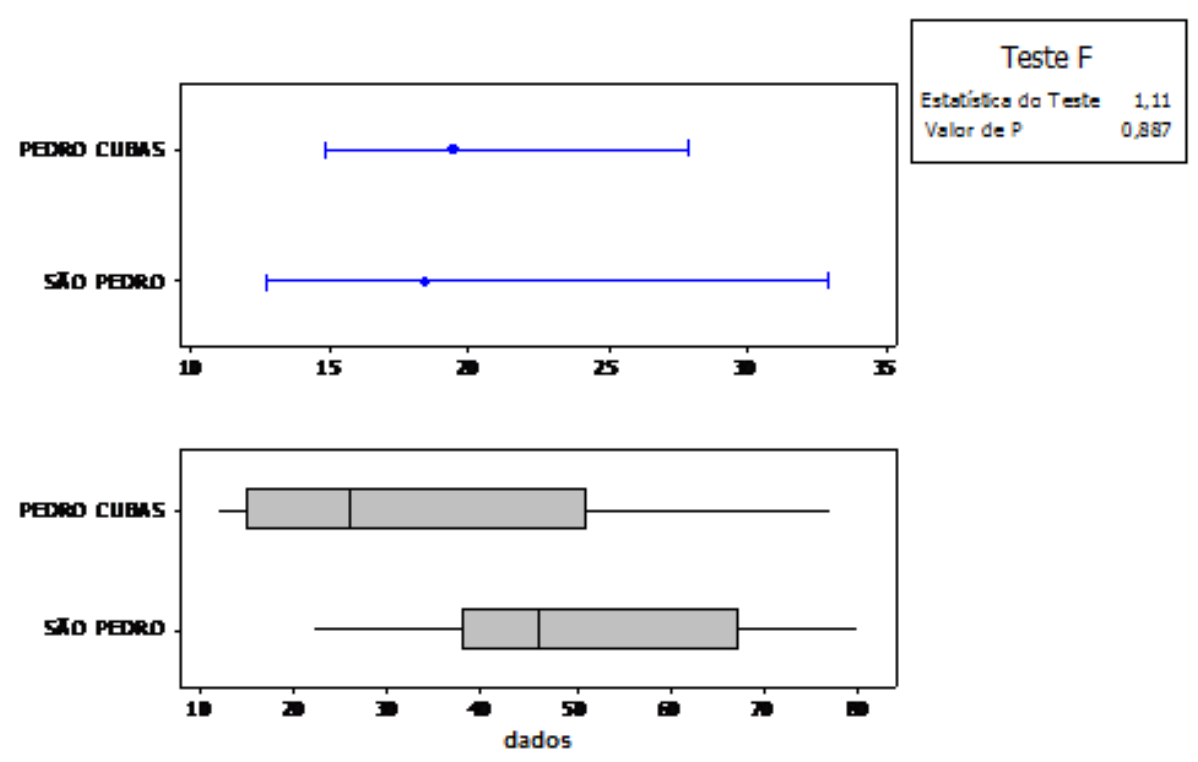

Figura 4.3: teste de Igualdade de Variâncias diversidade etnovariedades por jardim-quintal entre as comunidades quilombolas de São Pedro e Pedro Cubas
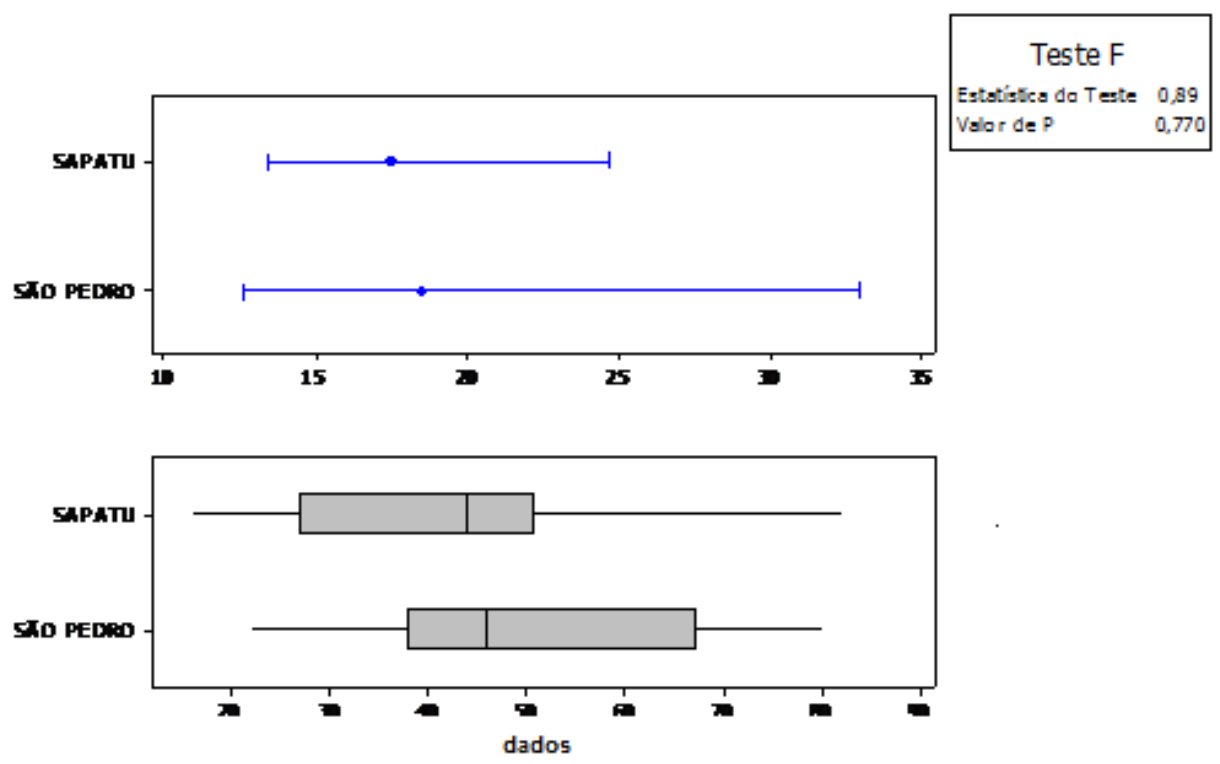

Figura 4.4: teste de Igualdade de Variâncias diversidade de etnovariedades por jardimquintal entre as comunidades quilombolas de São Pedro e Sapatu

Considerando a normalidade desse conjunto de dados, foi realizada a Análise de Variância simples (One-Way ANOVA, adotando Intervalo de Confiança de 95\%, nível de significância $\alpha$ de 0,05, 2 graus de liberdade), que testou a igualdade das médias da diversidade de etnovariedades distintas por jardim-quintal nas três 
comunidades em estudo (Figura 4.5). A Figura 4.5 mostra que houve diferença significativa entre as comunidades com relação à média de diversidade etnovariedades distintas por jardim-quintal $(F(2,66)=5,3092, p=0,00728)$. Não há sobreposição entre o intervalo que representa o erro da estimativa da média de São Pedro com relação ao mesmo intervalo relativo aos dados referidos coletados em Pedro Cubas. Portanto, Pedro Cubas e São Pedro apresentam valores médios de diversidade de etnovariedades por jardim-quintal estatisticamente distintos, enquanto que Sapatu não apresenta este comportamento, visto que os intervalos de confiança se sobrepõem em mais do que 5\%, tanto com Pedro Cubas quanto com São Pedro.

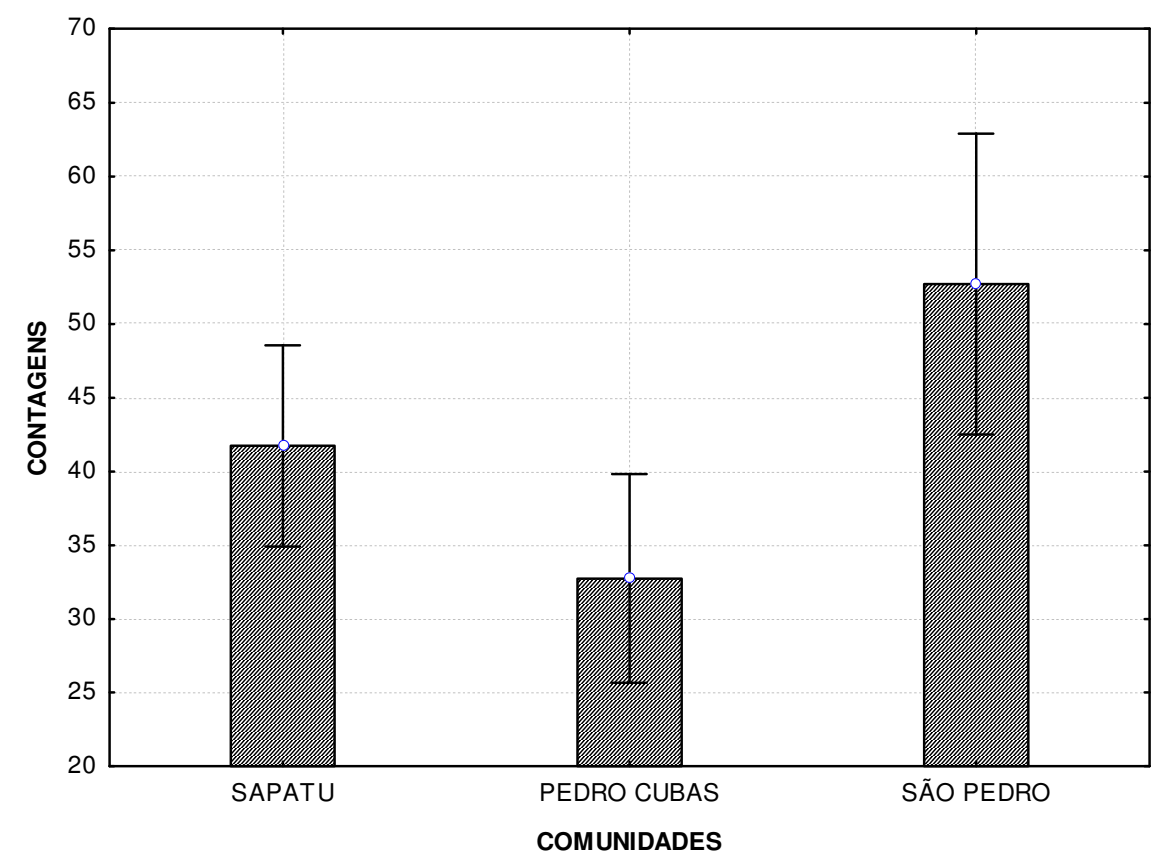

Figura 4.5: Análise de Variância para uma variável (One-Way ANOVA) para diversidade de etnovariedades por jardim-quintal nas comunidades quilombolas de Sapatu, Pedro Cubas e São Pedro

De todas as etnovariedades listadas (considerando as repetições), 79\% (2256) foram consideradas antigas, ou seja, são conhecidas e utilizadas pela comunidade desde os tempos dos pais e avós do informante (Figura 4.6). Os informantes mais novos entrevistados tinham 22 anos, sendo seus pais nascidos entre 1968 e 1943. Tendo isso em vista, foram consideradas antigas as etnovariedades que estavam sendo intencionalmente cultivadas nos jardins-quintal ou, no caso das nascidas espontaneamente, utilizadas pela comunidade, há pelo 
menos 40 anos (completados no período final de entrevistas, ou seja, 2008). Em contrapartida, as etnovariedades recentes seriam as que "apareceram" na comunidade há menos de 40 anos. De maneira geral, 21\% (604) das etnovariedades foram consideradas recentes (Figura 4.6). Eni, 40 anos, moradora de São Pedro, discorre sobre as plantas recentes:

\footnotetext{
"a maioria dessas planta a gente conhece quando a gente sai, quando a gente vai fazer o curso fora, então a gente chega lá e vê aquilo ali e pergunta. As pessoas falam a gente marca, e aí quando a gente acha na feira, porque às vezes a gente vê na feira e não sabe o que é, então não vai perguntar. Então, quando a gente sai, que a gente vê lá fora, a gente pergunta, quando vê na feira a gente interessa comprar pra prantar né. Que nem caju, caju eu tenho prantado um pé ali, mas ele, eu trouxe lá do Itimirim, mas aqui também ninguém nunca prantou. Num tem lugar nenhum, sempre diz assim: "ah, aqui num dá caju", mas ninguém prantou" (Eni, 40, São Pedro)
}

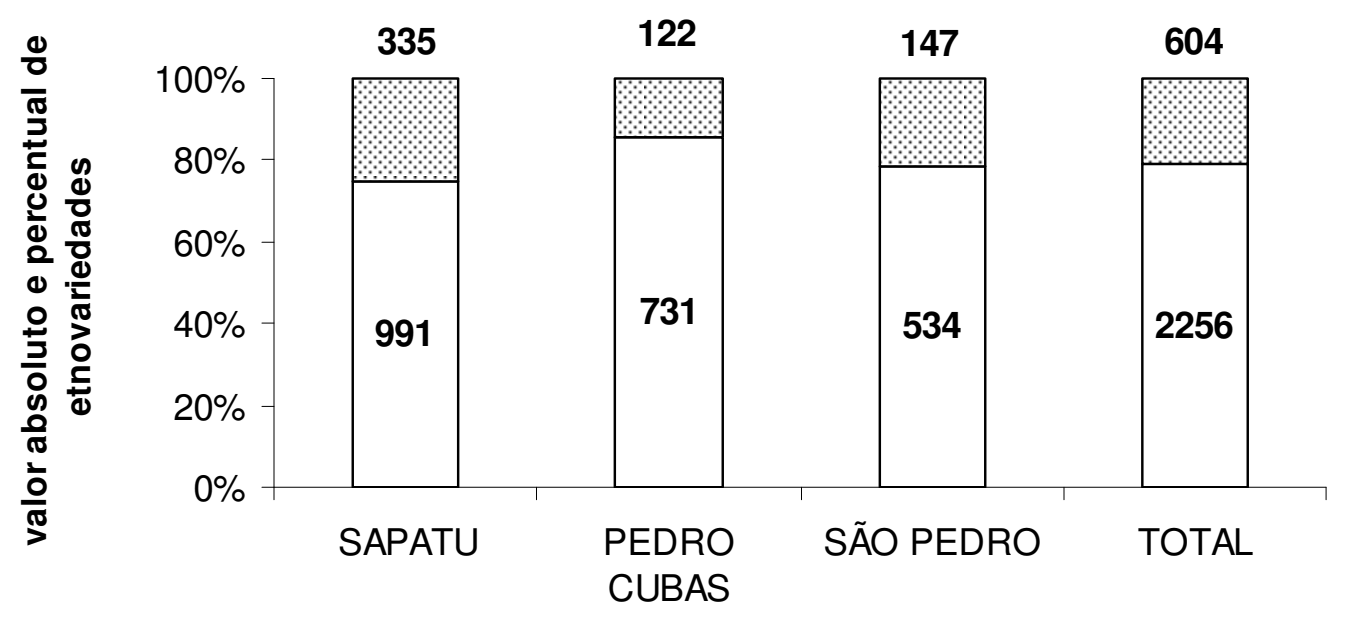

comunidades

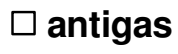

固 recentes

Figura 4.6: familiaridade dos informantes com as etnovariedades cultivadas em seus jardinsquintal das comunidades quilombolas de Sapatu, Pedro Cubas e São Pedro (antigas: há mais de 40 anos na comunidade; recentes: há menos de 40 anos)

Para comparações entre as comunidades com relação ao parâmetro "familiaridade com as etnovariedades cultivadas" foram consideradas as contagens "antigas" e "recentes" de cada um dos 71 levantamentos realizados (Figura 4.6). Foi observado que essas contagens não possuem uma distribuição normal segundo o 
teste de normalidade de Anderson-Darling para cada categoria, por isso, para este conjunto de dados foi aplicado o teste não-paramétrico de Kruskal-Wallis de comparação de medianas. As comunidades apresentaram diferenças significativas entre si apenas com relação às etnovariedades consideradas recentes $(H=11,13$; $\mathrm{GL}=2 ; \mathrm{p}=0,004$ ) (Tabela 4.2). As maiores diferenças ocorreram entre Pedro Cubas e Sapatu (Tabela 4.2).

Tabela 4.2: teste não-paramétrico de Kruskal-Wallis para comparação de medianas das contagens relativas as etnovariedades antigas e recentes. O símbolo * indica diferença significativa.

\begin{tabular}{|c|c|c|c|c|}
\hline \multirow{3}{*}{ familiaridade } & \multirow[b]{2}{*}{ Kruskal-Wallis } & \multicolumn{3}{|c|}{ COMUNIDADES } \\
\hline & & Sapatu & Pedro Cubas & São Pedro \\
\hline & & $\mathrm{n}=30$ & $n=27$ & $n=14$ \\
\hline \multirow{6}{*}{ antigas } & mediana & 32 & 25 & 40 \\
\hline & rank médio & 36,8 & 29,9 & 43,1 \\
\hline & $\mathbf{z}$ & 0,47 & $-1,78$ & 1,56 \\
\hline & $\mathbf{H}$ & \multicolumn{3}{|c|}{4,08} \\
\hline & DF & \multicolumn{3}{|c|}{2} \\
\hline & p & \multicolumn{3}{|c|}{0,13} \\
\hline \multirow{6}{*}{ recentes } & mediana & 8 & 3 & 9,5 \\
\hline & rank médio & 41,8 & 24,9 & 41,5 \\
\hline & $\mathbf{z}$ & 2,25 & $-3,34$ & 1,24 \\
\hline & H & \multicolumn{3}{|c|}{11,13} \\
\hline & DF & \multicolumn{3}{|c|}{2} \\
\hline & p & \multicolumn{3}{|c|}{$0,004^{*}$} \\
\hline
\end{tabular}

As Figuras 4.7, 4.8, 4.9 e 4.10 representam as famílias biológicas que tiveram maior abundância numérica de etnovariedades (ou seja, táxons que apareceram com maior freqüência nos jardins-quintal) para cada uma das comunidades e no total entre elas. Já as Figuras 4.11, 4.12, 4.13 e 4.14 representam as famílias biológicas com maior diversidade de etnovariedades, também para cada uma das comunidades e considerando o total geral entre elas. 


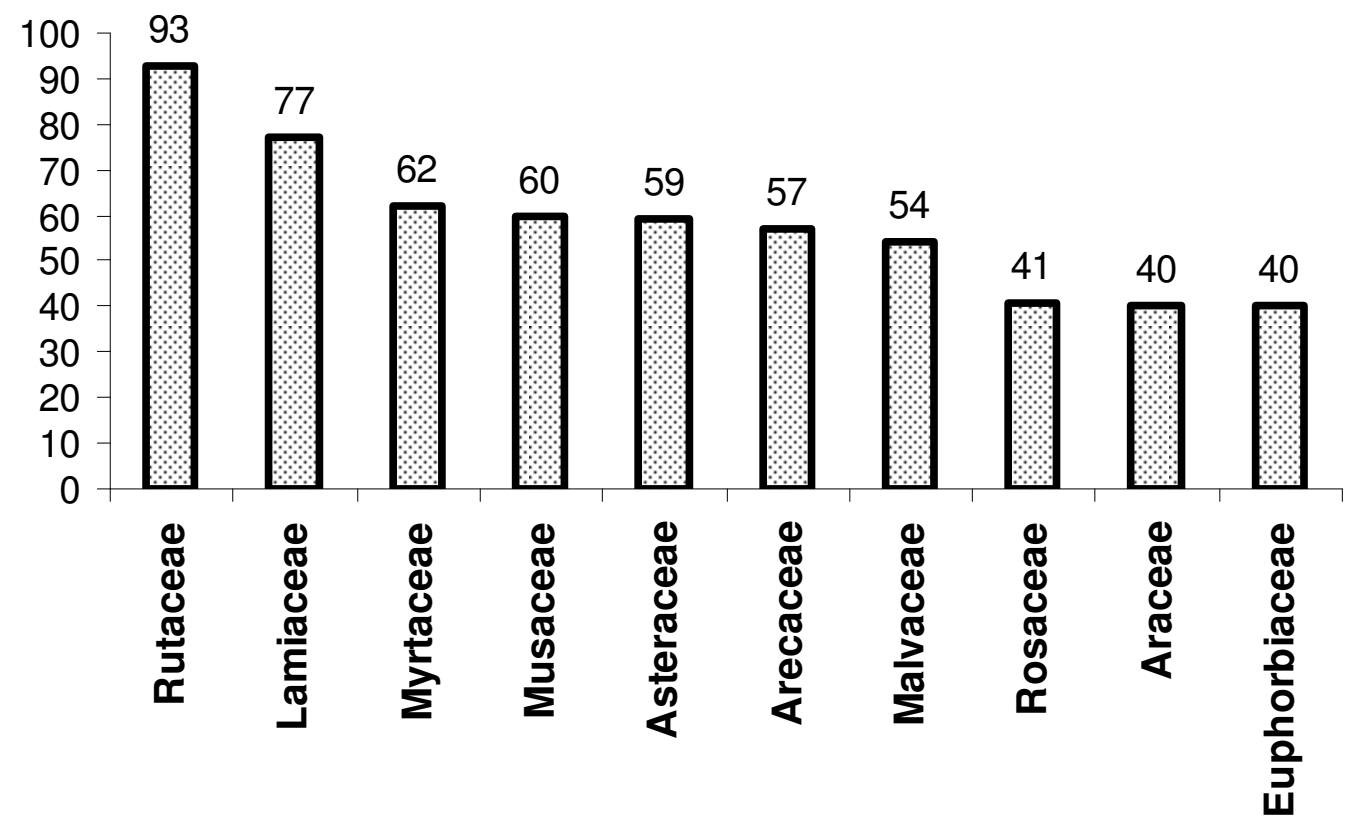

Figura 4.7: famílias biológicas que tiveram maior abundância numérica de etnovariedades nos jardins-quintal da comunidade quilombola de Sapatu

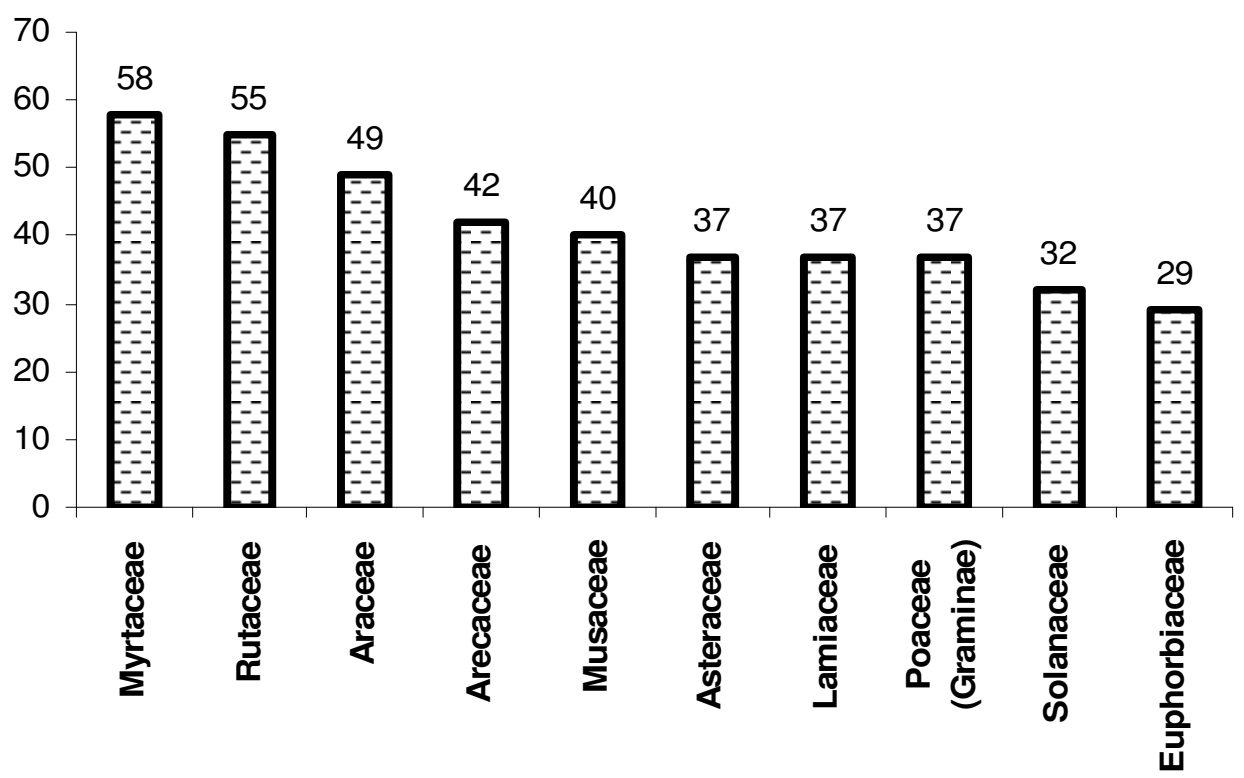

Figura 4.8: famílias biológicas que tiveram maior abundância numérica de etnovariedades nos jardins-quintal da comunidade quilombola de Pedro Cubas 


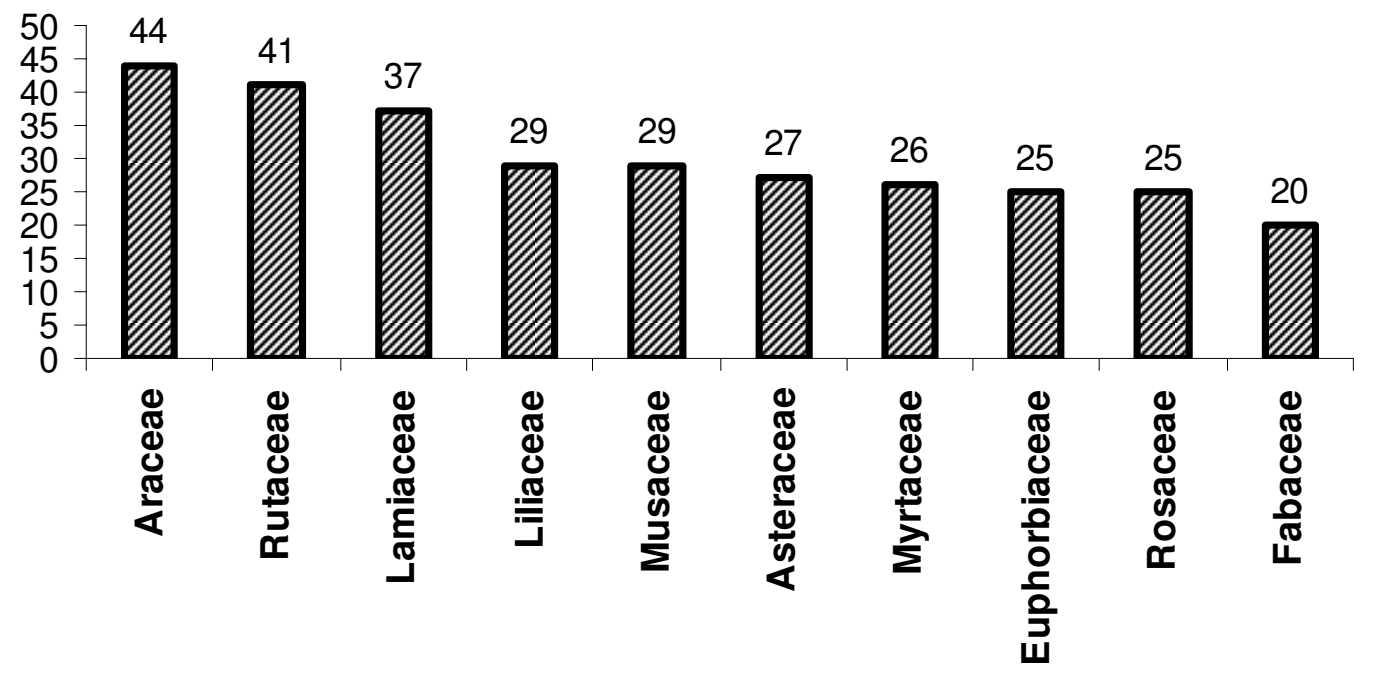

Figura 4.9: famílias biológicas que tiveram maior abundância numérica de etnovariedades nos jardins-quintal da comunidade quilombola de São Pedro

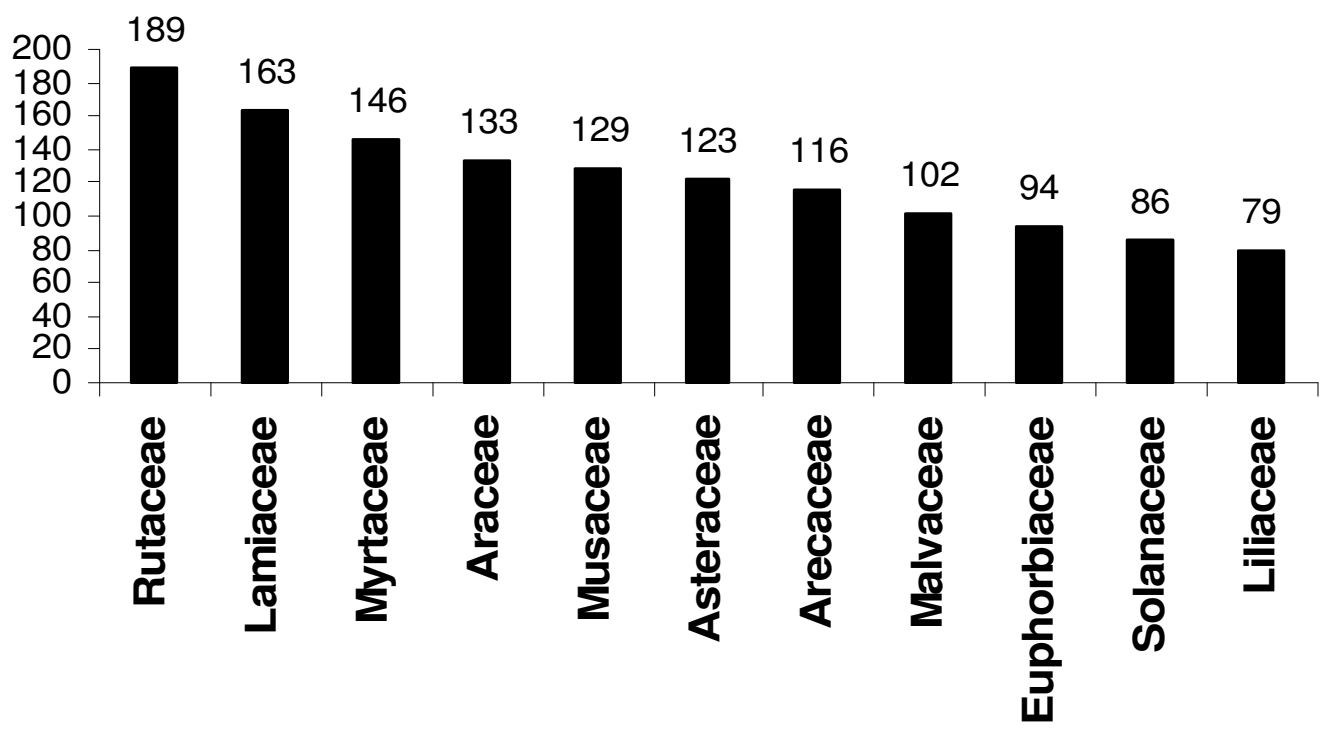

Figura 4.10: famílias biológicas que tiveram maior abundância numérica de etnovariedades nos jardins-quintal para total geral entre as comunidades quilombolas de Sapatu, Pedro Cubas e São Pedro 


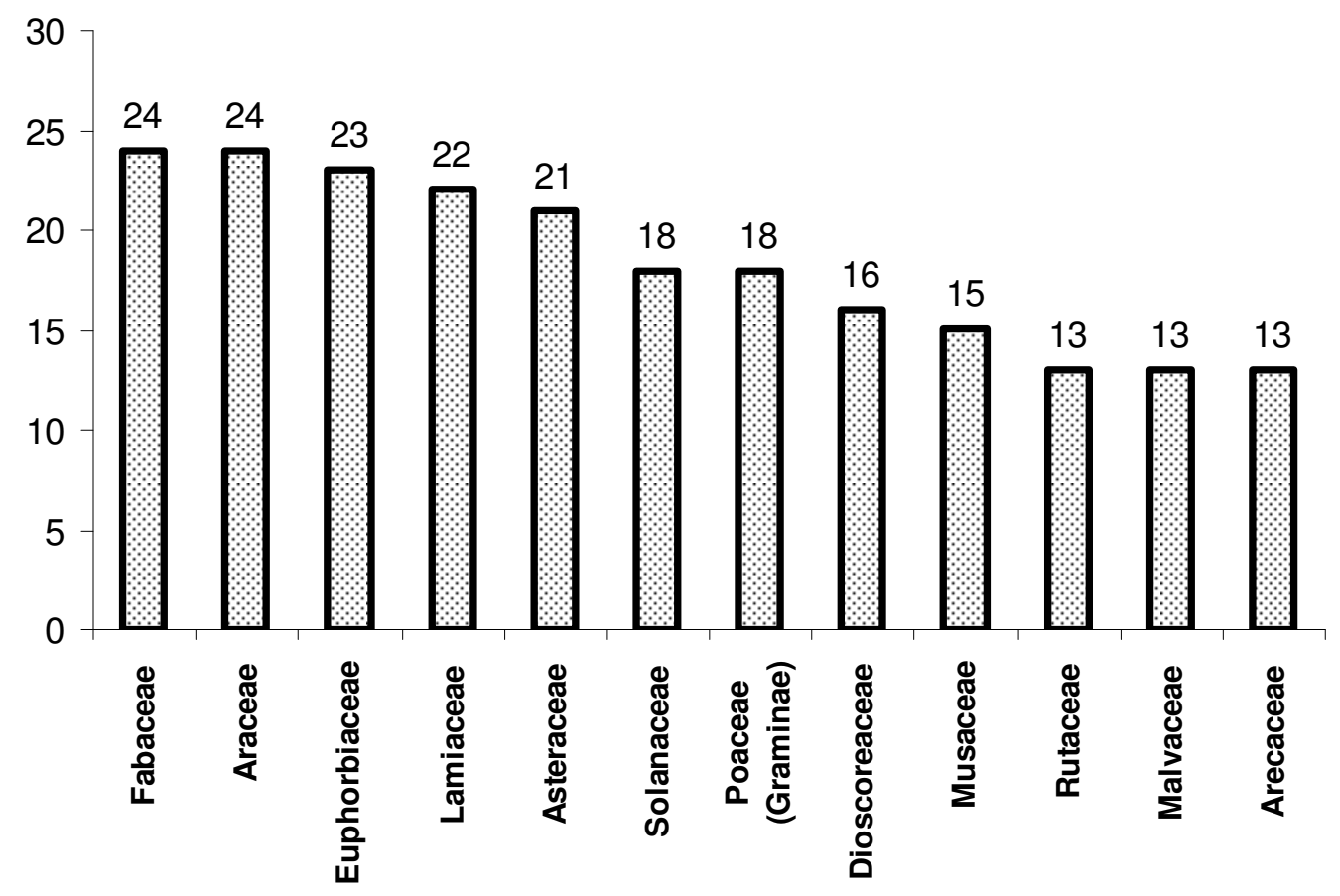

Figura 4.11: famílias biológicas com maior diversidade de etnovariedades nos jardins-quintal da comunidade quilombola de Sapatu

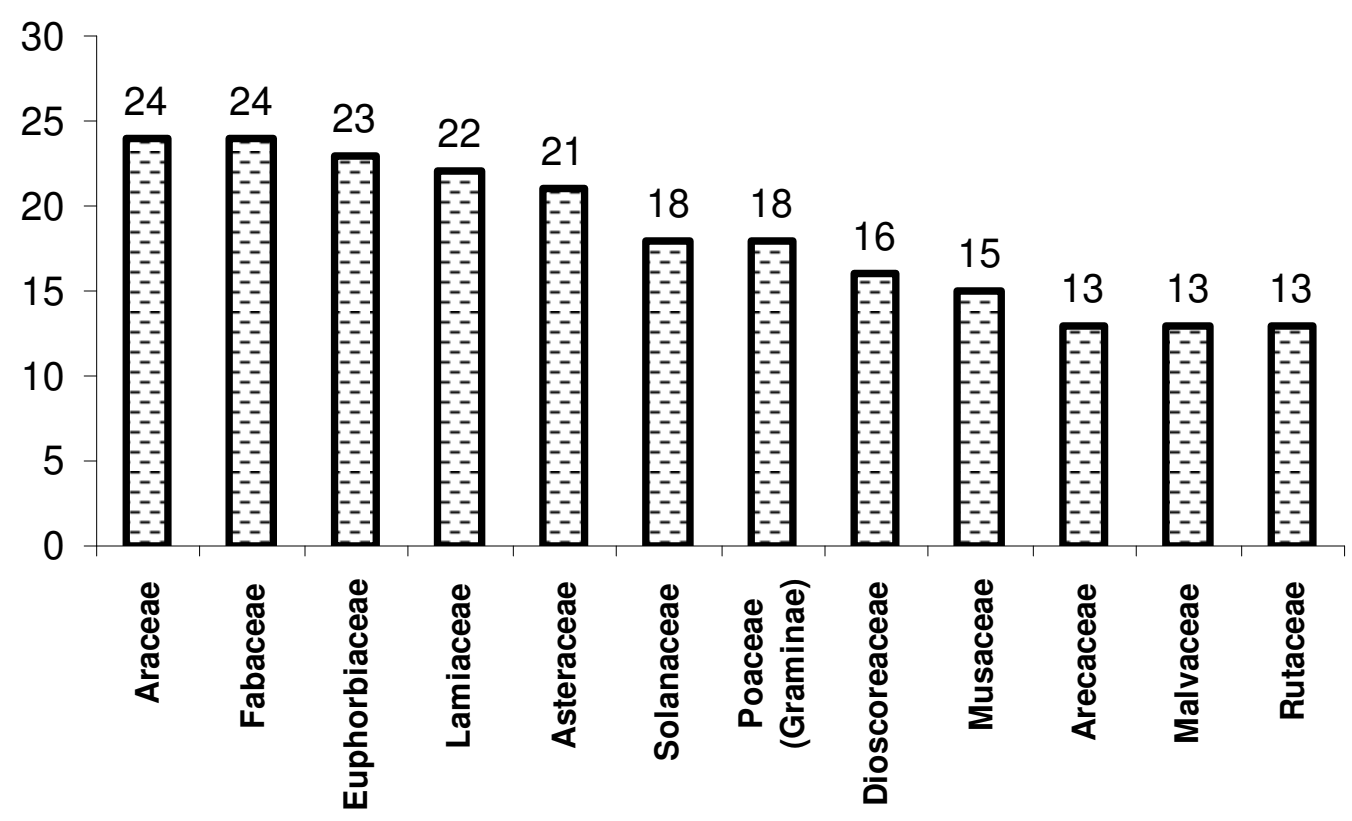

Figura 4.12: famílias biológicas com maior diversidade de etnovariedades nos jardins-quintal da comunidade quilombola de Pedro Cubas 


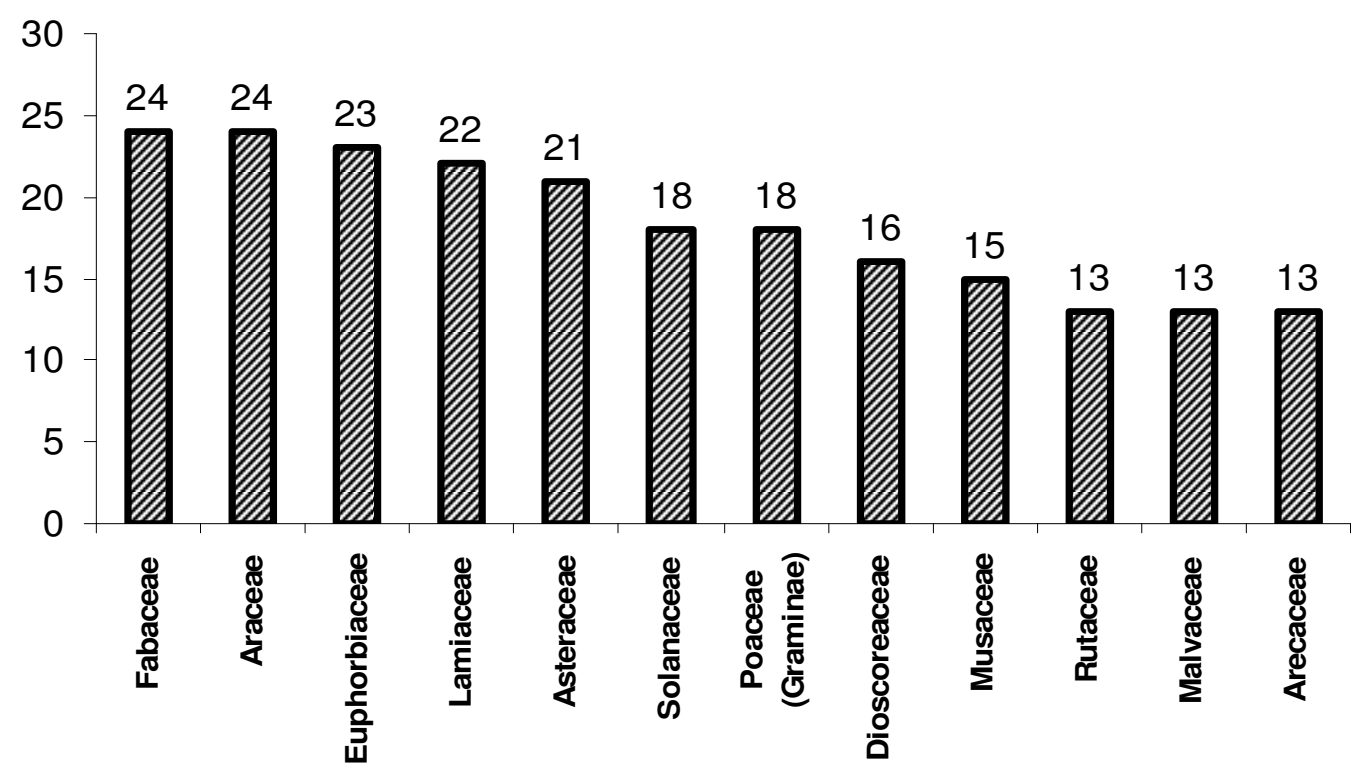

Figura 4.13: famílias biológicas com maior diversidade nos jardins-quintal da comunidade quilombola de São Pedro

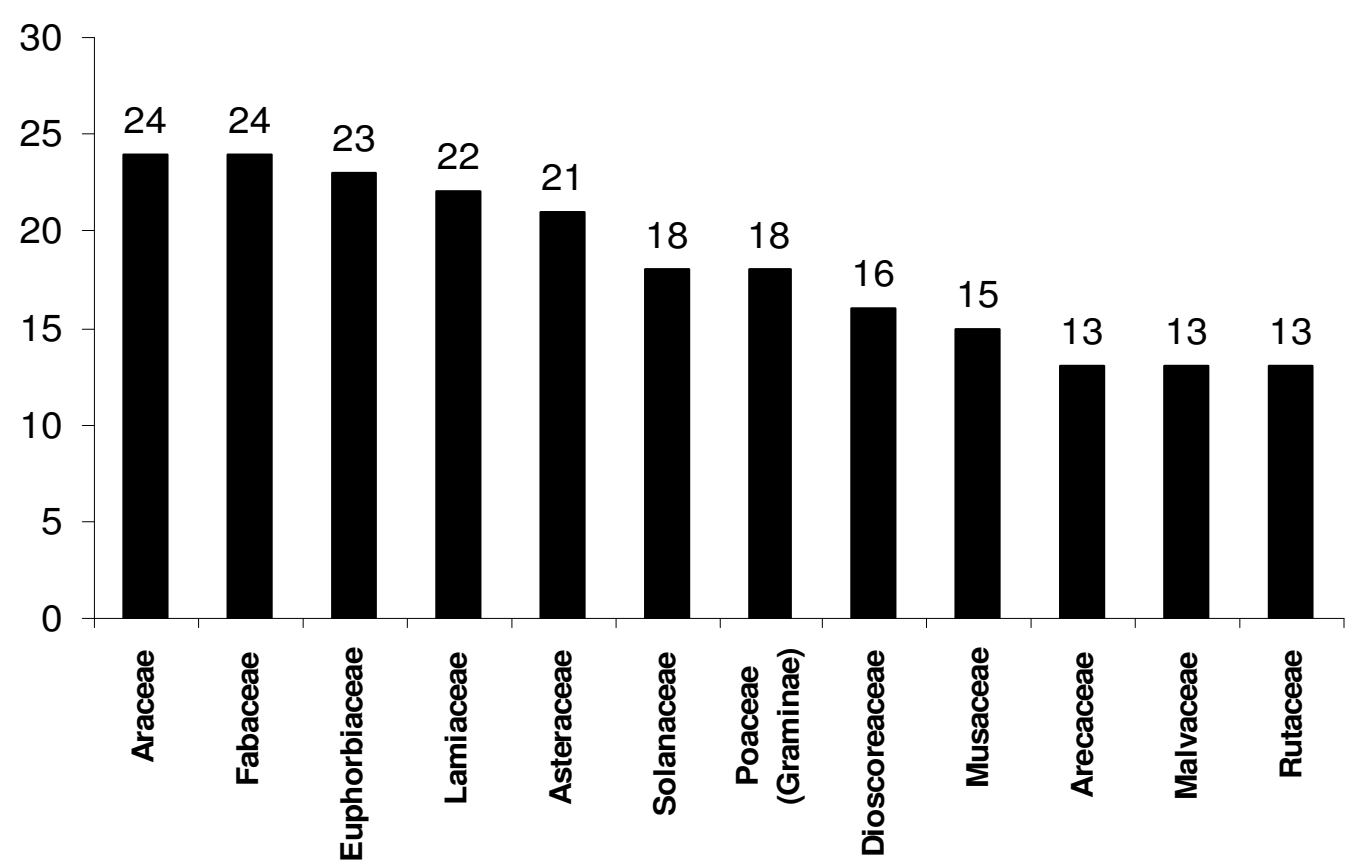

Figura 4.14: famílias biológicas com maior diversidade nos jardins-quintal para total geral entre as comunidades quilombolas de Sapatu, Pedro Cubas e São Pedro 


\subsection{Estrutura dos Jardins-quintal}

\subsubsection{Estratos verticais: os hábitos de vida vegetal}

Estruturalmente, os jardins-quintal observados são compostos por estratos de dossel verticais com três a quatro camadas (arbóreo, arbustivo e herbáceo) (Figura 4.15 e 4.16), contanto ainda com outras formas de vida vegetal, como lianas e epífitas. A Figura 4.16 mostra a proporção em que cada estrato aparece nos jardinsquintal das comunidades estudadas, considerando as contagens totais de etnovariedades (abundância numérica) por estrato (ou seja, novamente não foram descartadas as repetições de etnovariedades entre os jardins-quintal, e sim acumuladas). 

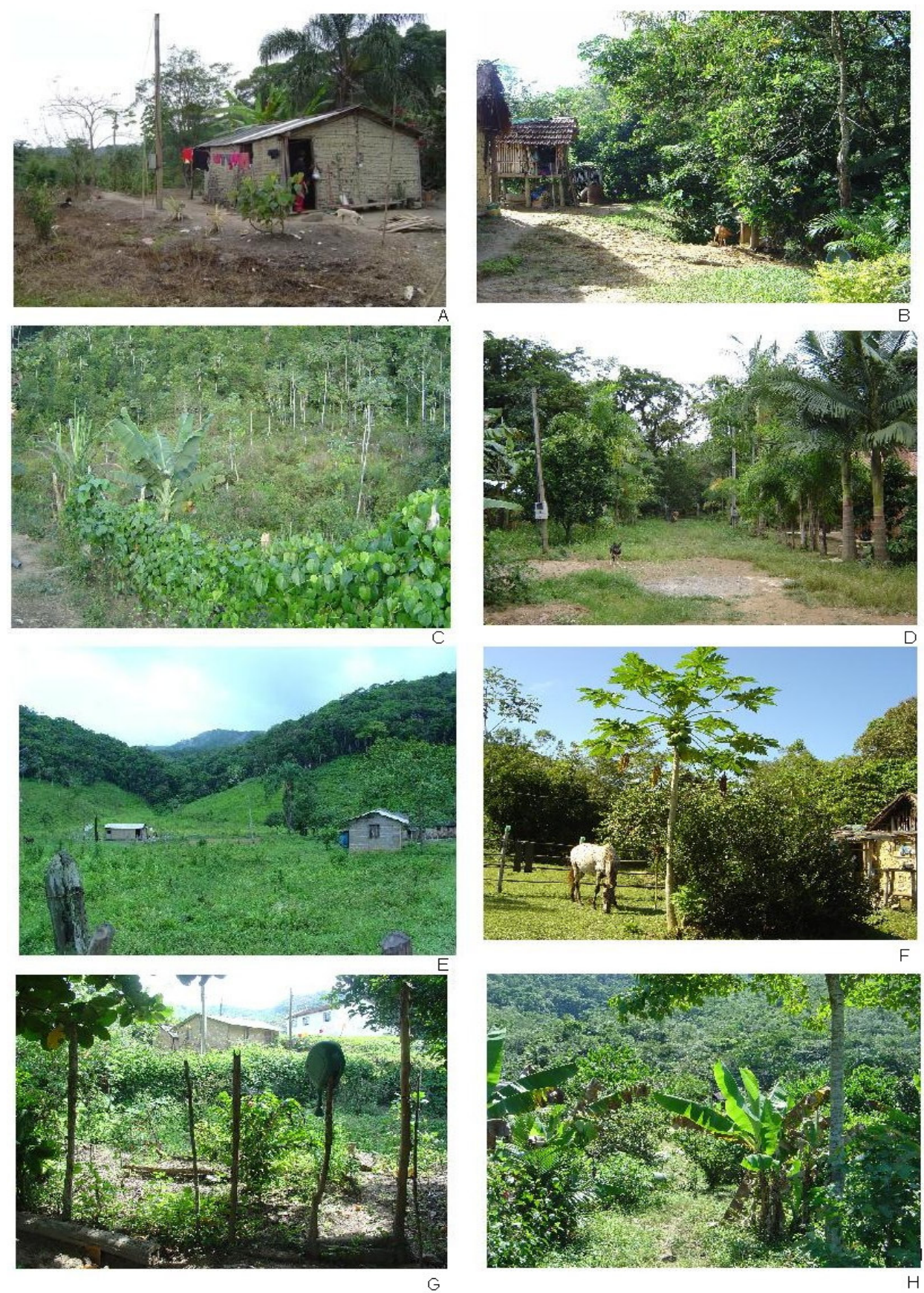

Figura 4.15: panorama geral de alguns jardins-quintal, relevando os principais estratos verticais da vegetação (A-F: UDs na comunidade de Pedro Cubas; G-H: UDs na comunidade de São Pedro) 


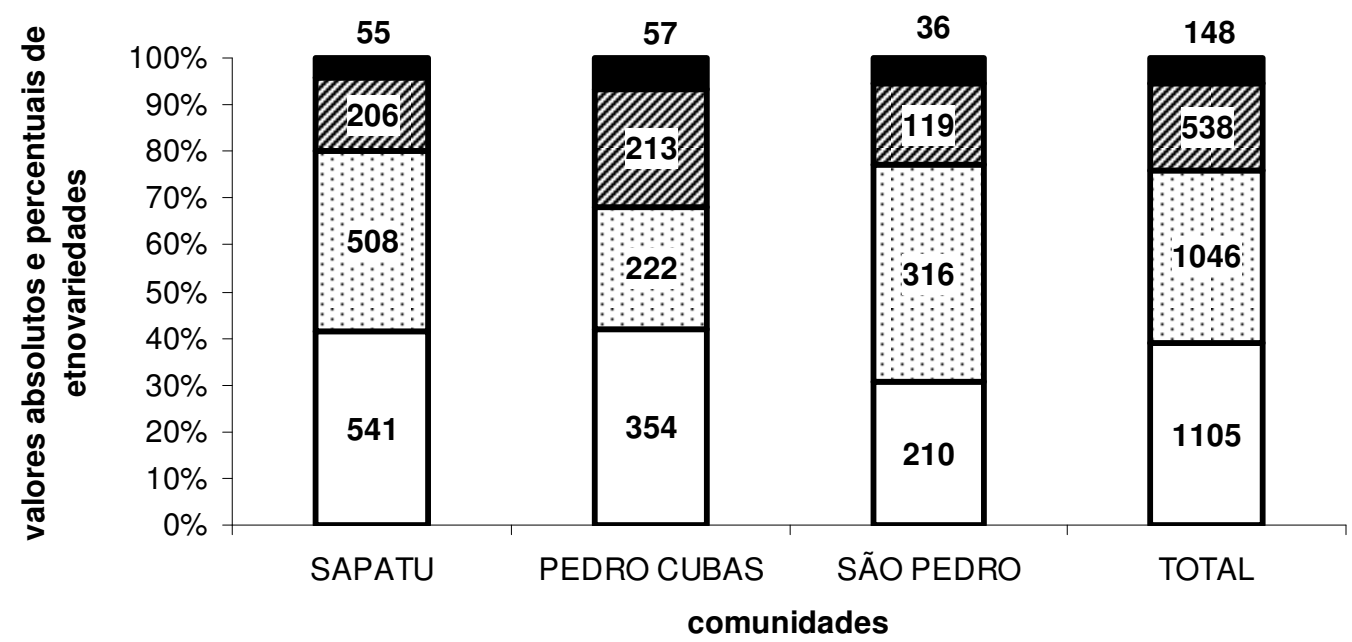

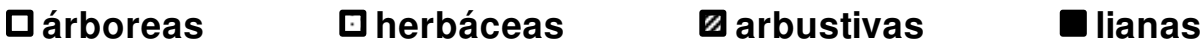

Figura 4.16: proporções que cada estrato ocupa nos jardins-quintal das três comunidades quilombolas estudadas (Sapatu, Pedro Cubas e São Pedro), e abundância numérica total (considerando repetições) de etnovariedades para cada um dos estratos

Foram consideradas arbóreas as etnovariedades lenhosas em geral acima de 5 metros de altura, com tronco único e nítido, sem ramificações na parte inferior. As espécies arbustivas contemplam as etnovariedades lenhosas com altura média inferior a 5 metros de altura, e ramificadas a partir da base. O estrato herbáceo, por sua vez, foi caracterizado para esse estudo como sendo aquele que contém etnovariedades não lenhosas, pouco lignificadas, anuais ou bianuais, raramente perenes.

As comunidades foram comparadas entre si com relação à distribuição de etnovariedades distintas por categoria do estrato vertical. Essas contagens não possuem uma distribuição normal segundo o teste de normalidade de AndersonDarling para cada categoria. As comunidades de Sapatu, Pedro Cubas e São Pedro são estatisticamente diferentes entre si com relação apenas ao componente herbáceo, sendo Pedro Cubas e São Pedro as que apresentam maiores diferenças entre si com relação a esse parâmetro ( $H=18,92 ; G L=2 ; p=0,000)$ (Tabela 4.3). 
Tabela 4.3: teste não paramétrico de Kruskal-Wallis para etnovariedades distribuídas nos diferentes estratos verticais da vegetação dos jardins-quintal. O símbolo * indica diferença significativa, ao nível de significância de $5 \%$. (continua).

\section{COMUNIDADES}

\begin{tabular}{|c|c|c|c|c|}
\hline estratos & Kruskal-Wallis & $\begin{array}{l}\text { Sapatu } \\
n=30\end{array}$ & $\begin{array}{l}\text { Pedro Cubas } \\
\qquad n=27\end{array}$ & $\begin{array}{c}\text { São Pedro } \\
n=14\end{array}$ \\
\hline \multirow{9}{*}{ arbóreo } & mediana & 17 & 10 & 14 \\
\hline & rank médio & 42,3 & 29,9 & 34,3 \\
\hline & $\mathbf{z}$ & 2,2 & $-1,95$ & $-0,35$ \\
\hline & $\mathbf{H}$ & & 5,28 & \\
\hline & DF & & 2 & \\
\hline & $\mathbf{p}$ & & 0,071 & \\
\hline & mediana & 5 & 5 & 9 \\
\hline & rank médio & 34,1 & 35,2 & 41,5 \\
\hline & $\mathbf{z}$ & $-0,66$ & $-0,24$ & 1,11 \\
\hline \multirow[t]{6}{*}{ arbustivo } & $\mathbf{H}$ & & 1,29 & \\
\hline & DF & & 2 & \\
\hline & $\mathbf{p}$ & & 0,525 & \\
\hline & mediana & 17 & 7 & 19 \\
\hline & rank médio & 40,3 & 23,4 & 51,1 \\
\hline & $\mathbf{z}$ & 1,5 & $-4,03$ & 3,06 \\
\hline \multirow[t]{6}{*}{ herbáceo } & $\mathbf{H}$ & & 18,92 & \\
\hline & DF & & 2 & \\
\hline & $\mathbf{p}$ & & $0,000^{\star}$ & \\
\hline & mediana & 1 & 2 & 2 \\
\hline & rank médio & 33 & 36,5 & 41,5 \\
\hline & $\mathbf{z}$ & $-1,05$ & 0,16 & 1,11 \\
\hline \multirow[t]{3}{*}{ lianas } & $\mathbf{H}$ & & 1,74 & \\
\hline & DF & & 2 & \\
\hline & $\mathbf{p}$ & & 0,418 & \\
\hline
\end{tabular}


Continuação da Tabela 4.3: teste não paramétrico de Kruskal-Wallis para etnovariedades distribuídas nos diferentes estratos verticais da vegetação dos jardins-quintal. O símbolo * indica diferença significativa, ao nível de significância de 5\%..

\begin{tabular}{ccccc}
\hline \multirow{2}{*}{ estratos } & Kruskal-Wallis & Sapatu & $\begin{array}{c}\text { COMUNIDADES } \\
\text { Pedro Cubas }\end{array}$ & São Pedro \\
\hline \multirow{4}{*}{ epifitas } & mediana & 0 & 0 \\
& rank médio & 31,8 & 37,6 \\
& $\mathbf{z}$ & $-1,46$ & 0,52 \\
\cline { 2 - 5 } & $\mathbf{H}$ & & 4,17 \\
& $\mathbf{D F}$ & & 2 \\
\hline $\mathbf{p}$ & & 0,124 \\
\hline
\end{tabular}

4.2.2 As zonas de cultivo

É possível distinguir sete zonas principais para o cultivo de etnovariedades (Figuras 4.17 e 4.18). Há, no entanto, sobreposição de estratos e contínuo recrutamento de espécies nessas diferentes zonas. Uma delas é um espaço de vivência, local mais próximo à casa, com pouca vegetação, comumente utilizada como um terraço onde as crianças podem brincar e os adultos descansar. Este espaço é localmente denominado de "terreiro" (embora o termo possa também designar, de uma maneira mais inclusiva, o espaço mais próximo à casa), uma área onde a terra é altamente compactada, "lavada" e freqüentemente varrida pelas mulheres da casa. Nas palavras dos informantes:"o terreiro é mais limpo (que a roça) (...) é em volta da casa" ou "a parte de terra que tem em volta da casa é terreiro" (Ilda, 33, Sapatu), ou ainda "(...) o terreiro que eu sei assim é a parte limpa" (Guida, 40, Sapatu). 


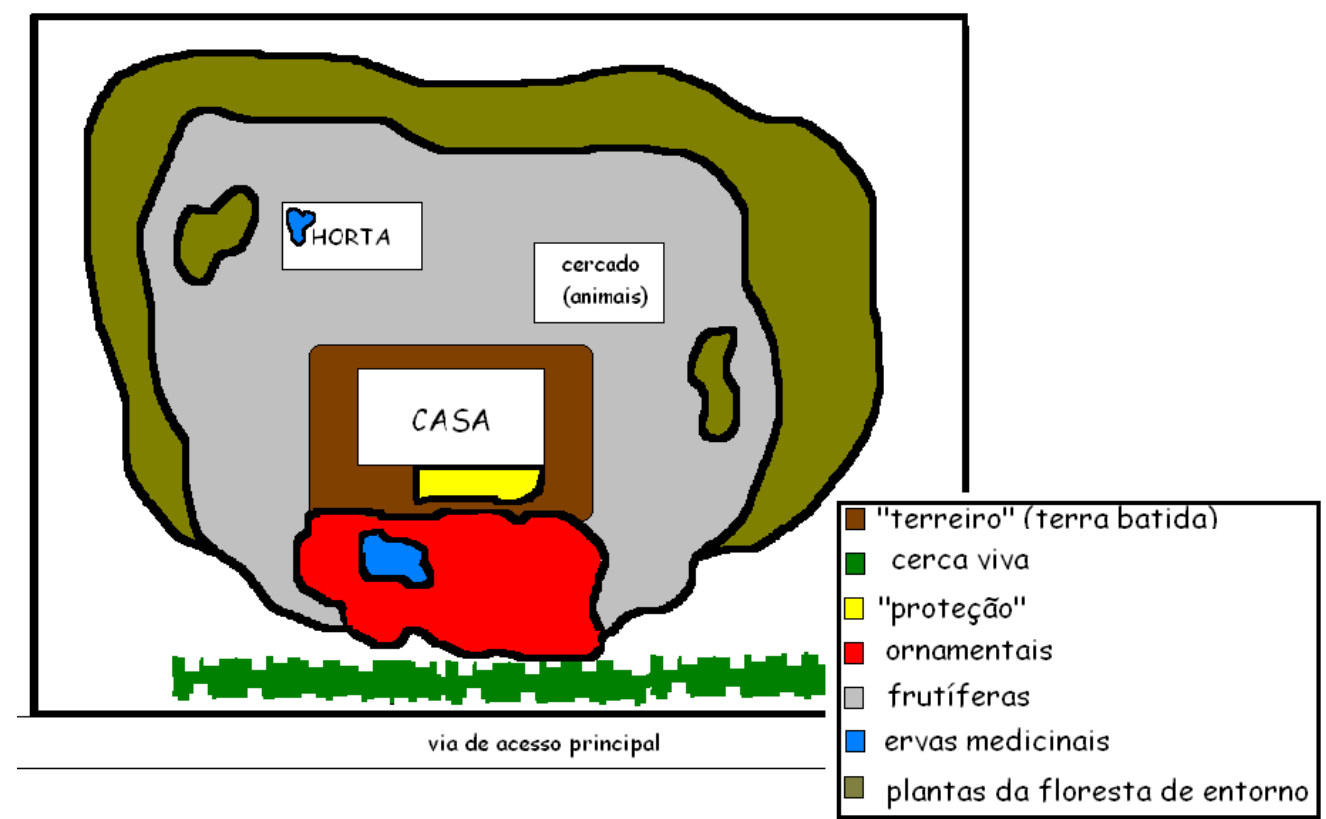

Figura 4.17: esquema da configuração espacial geral dos jardins-quintal das comunidades quilombolas de São Pedro e Pedro Cubas

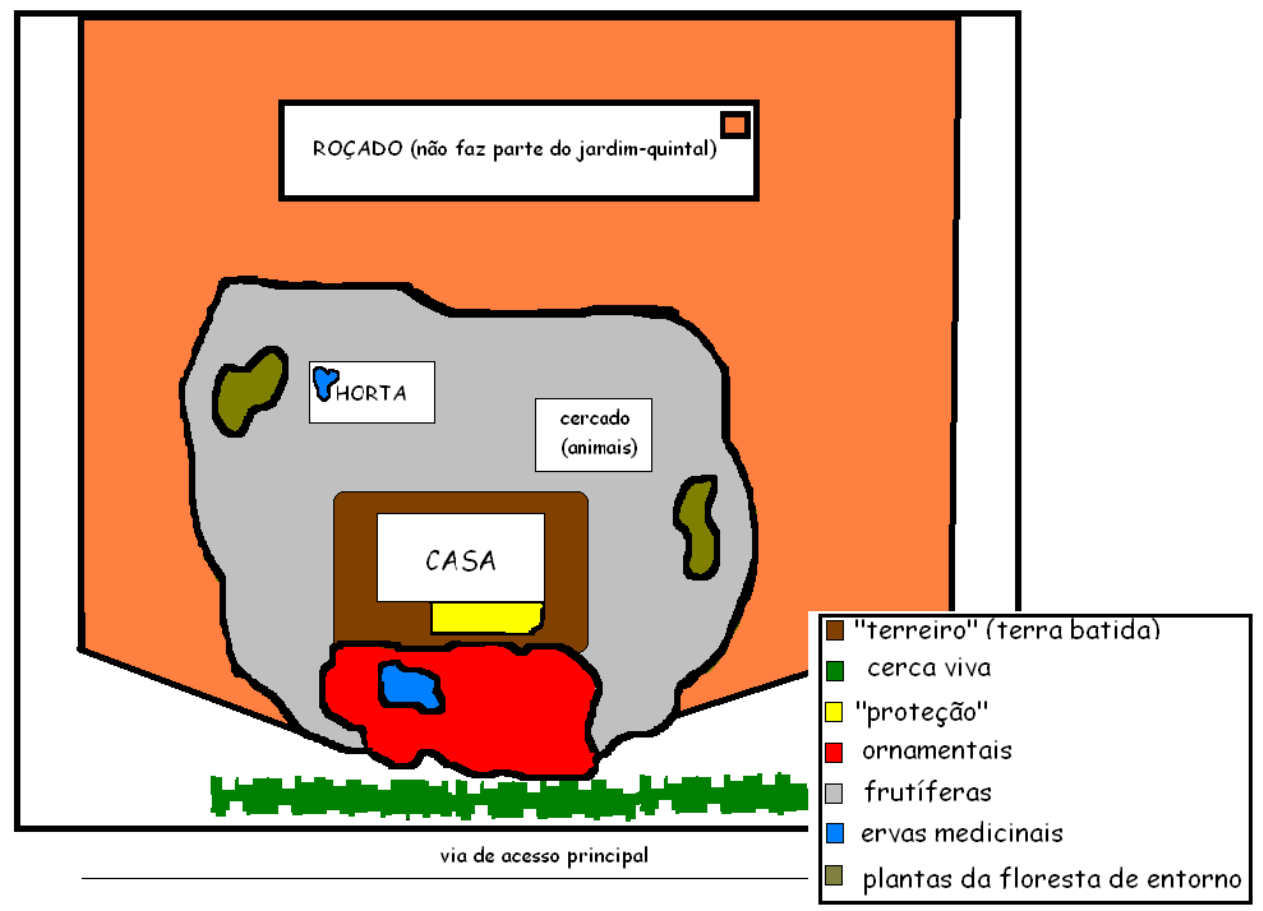

Figura 4.18: Esquema da configuração espacial geral dos jardins-quintal da comunidade quilombola de Sapatu 
A segunda zona comumente se sobrepõe à primeira, e é extremamente restrita e dedicada ao cultivo de etnovariedades de função estritamente simbólicaafetiva, as quais a população local atribui funções como a proteção "espiritual" à casa e seus membros. Uma terceira zona é àquela onde predominam as etnovariedades ornamentais, geralmente encontradas nas áreas próximas ao acesso principal da casa. A quarta zona identificada é aquela destinada ao cultivo de ervas medicinais, podendo esta estar à frente da casa (para um acesso facilitado) ou junto às demais etnovariedades herbáceas geralmente cultivadas na horta. A horta, outra zona distinta de manejo, é geralmente cercada (com varas e arames) para evitar os danos causados pela criação, e se localiza normalmente no terreno atrás da casa. As hortas são predominantemente sazonais, sendo cultivadas durante os períodos mais quentes e chuvosos (entre setembro e março). A sexta zona é, na verdade, uma área não claramente delimitada, mas que se concentra significativamente atrás da casa, onde predominariam plantas frutíferas e árvores que produzem sombra. $A$ sétima zona é o local onde se misturam plantas não cultivadas com árvores domésticas de diversas espécies nos limites do jardim-quintal. Normalmente, essas espécies vegetais são utilizadas como material para construção, cultivo de mudas potenciais, fonte de frutas silvestres ou de plantas com fins medicinais.

Dentre as três comunidades investigadas, duas delas (São Pedro e Pedro Cubas) apresentam uma estrutura espacial semelhante a apresentada na Figura 4.17 Os jardins-quintal de Sapatu, por sua vez, apresentam uma configuração de zonas semelhante à apresentada na Figura 4.18, ou seja, o espaço onde geralmente se desenvolvem as árvores nascidas espontaneamente (provenientes da floresta do entorno) são via de regra suprimidas em favorecimento ao cultivo de plantas comerciais mais produtivas. Normalmente, os roçados adjacentes aos jardins-quintal de Sapatu incluem variedades como banana (Musa paradisiaca L.), feijão (Phaseolus vulgaris L.), mandioca (Manihot esculenta Crantz), milho (Zea mays L.), cará (Dioscorea sp.), cana (Saccharum officinarum L), abóbora (Curcubita sp.), arroz (Oryza sativa L.) e batata-doce (Ipomoea batatas (L.) Lam.) (Pedroso-júnior et al 2008b).

Variações com relação a esses esquemas representativos das zonas de manejo dizem respeito principalmente à localização da horta (que pode ser cultivada preferencialmente no espaço em frente a casa), e a presença ou não de espaços 
reservados exclusivamente para a criação de animais (Apêndice $F$ ). A delimitação entre a predominância de plantas destinadas a um objetivo de cultivo principal em cada uma das zonas também raramente ocorre de maneira clara. O que acontece de fato é a sobreposição dessas diversas zonas com maior ou menor intensidade dentre os diferentes jardins-quintal amostrados (Apêndice F). O mosaico formado por essas diferentes manchas de etnovariedades é diverso, e a presença e ausência de alguns desses sub-componentes pode acontecer.

\subsection{As múltiplas funções do jardim-quintal}

Foram verificadas 12 categorias distintas de uso, tanto para as plantas em si quanto para seus derivados (como a farinha produzida a partir da mandioca Manihot esculenta Crantz). A Figura 4.19 exemplifica alguns desses múltiplos-usos. Dentre eles, 4 congregam o maior número de etnovariedades cultivadas no espaço dos jardins-quintal para as três comunidades: alimentação da família, ornamentação, medicinal e as simbólico-afetivas (função não material ou de uso não imediato, como preservação da memória dos antepassados, atração de animais silvestres para contemplação, lembranças de parentes e amigos) (Apêndice F). As demais categorias de uso reúnem poucas variedades de plantas cultivadas para esse fim, mas possuem aplicações também relevantes: as utilizadas como material de construção (casas, barracões e cercas) combustível (lenha), matéria prima para artesanato, comercialização, cosmética (produtos utilizados no cuidado com o cabelo e higiene pessoal), para manutenção da criação (alimentação ou medicação), sombreamento e como viveiro de mudas (perpetuação daquela etnovariedade sob o domínio da família). 

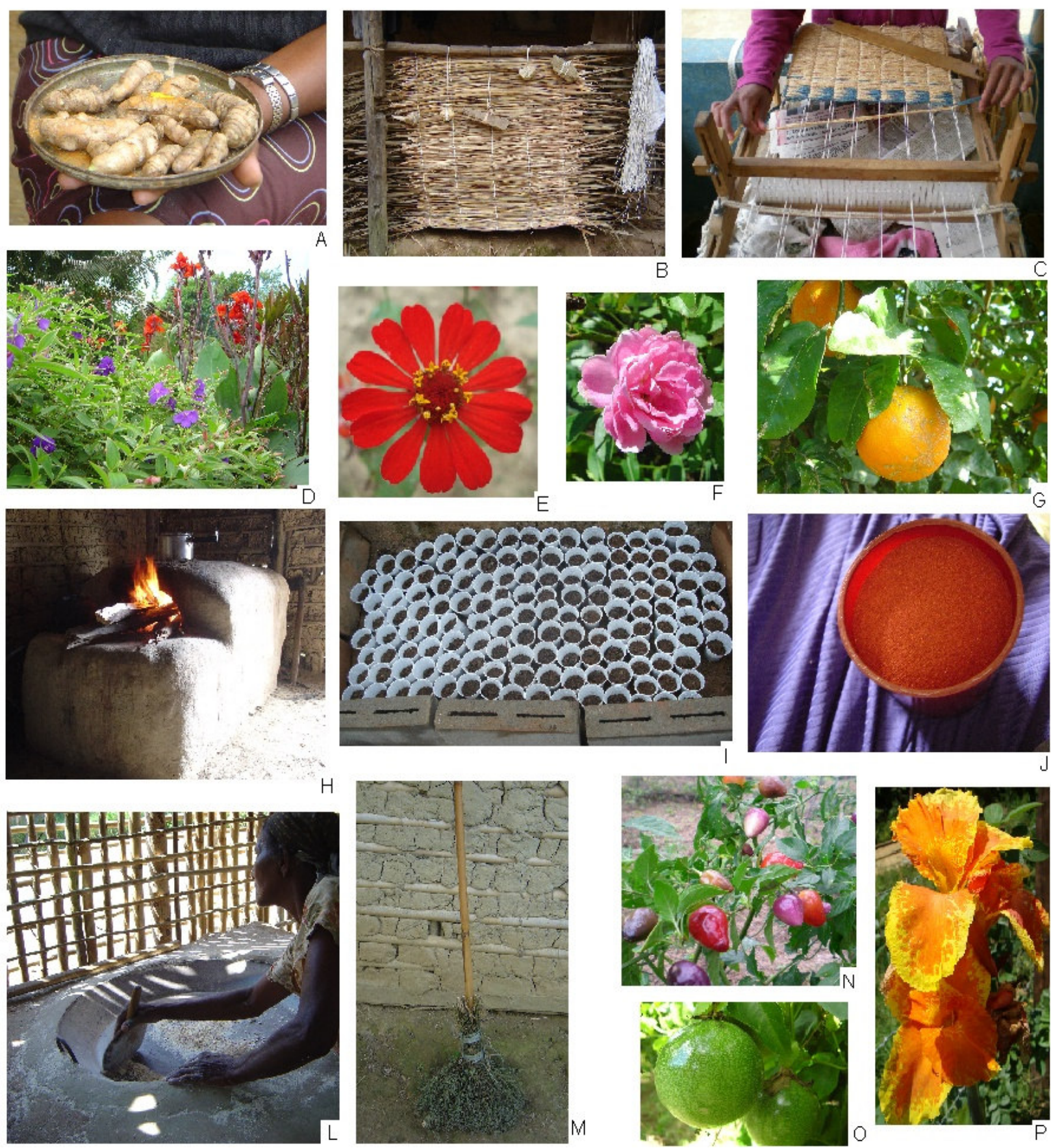

Figura 4.19: alguns dos múltiplos usos de etnovariedades cultivadas nos jardins quintal das comunidades quilombolas de Sapatu, Pedro Cubas e São Pedro (A, G, J, L, N, O: alimentação; B, C: artesanato de folha de bananeira (Musa sp.); D, E, F, P: etnovariedades ornamentais; H: fogão aceso com lenha local; I: mudas de maracujá (Passiflora edulis Sims) - plantação para comercialização; $\mathbf{M}$ : vassoura feita de guanxuma (Sida sp.); J: pó resultante do processamento da semente do urucum (Bixa orellana L.); L: farinha de mandioca (Manihot esculenta Crantz) sendo torrada) 
A categorização dos objetivos de cultivo foi realizada após a interpretação das descrições e comentários dos próprios informantes. A seguir estão alguns exemplos destas definições colocadas pelos próprios informantes em campo. Mora, 59 anos, moradora de São Pedro, fala sobre uma etnovariedade destinada à ornamentação: "não, no usa pra nada, só pra enfeite" (sobre o "beijo" - Impatiens walleriana Hook. f.). Tida, 29 anos, de São Pedro, quando questionada sobre o porquê do cultivo da "onze horas" (Portulaca oleracea L.) em seu jardim, relata: "É, porque eu gosto... pra enfeite, assim". A mesma informante fala sobre seu roseiral (Rosa sp.):

\begin{abstract}
"Essa rosa rosa é... Meu pai que tinha.... Ele era também fissurado em planta... Ele conseguiu a muda não sei aonde, aí eu peguei a muda do meu pai. Essa também dá flor o ano inteiro, ela tem um... Dizem que tem uma rosa que ela dá... Dá flor ... Só uma vez por ano, mas essa daqui, que diz que é ela né, mas só que essa daí ela... Pra mim ela dá direto, o ano inteiro. (...) Aí quando cai essas pétalas aqui, eu corto tudo isso daqui, aí elas, daqui a pouco elas tão, já dão esses brotos aqui de novo pra florescer... Aí ela fica o ano inteiro, o mês inteiro, é a coisa mais linda essa rosa aqui..." (Tida, 29, São Pedro, sobre a "rosa")
\end{abstract}

Sobre as etnovariedades destinadas à alimentação da família, são exemplos a banana "pacova" (Musa sp. L): "quando ela dá o cacho a gente deixa madurar pra gente comer... frito, assado, cozido... crua..." (Tida, 29, São Pedro); a "goiaba": "Isso é... Goiaba!... É de comê..." (Mirabel, 62 anos, Pedro Cubas); o "mangarito" (Colocasia esculenta (L.) Schott): "Muito bom pra comer, coloca na sopa, coloca pra servi com com café... Muito bom isso aí..." (idem); e a "laranja" (Citrus sinensis (L.) Osbeck):

\begin{abstract}
"Essa é uma laranjeira que tem lá na Vargem, lá pra frente, na casa de Edu Onofre de França. Ela dá enorme, e dá uma laranja assim desse tamanho, bem grandona. Quando ela tá verde, ela não amarela assim pra poder tá madura, pra chupar, ela verde mesmo pode chupar" (Tida, 29, São Pedro, sobre a "laranjeira")
\end{abstract}

Tida, 63, Pedro Cubas, fala ainda sobre o "taiá" ou "taioba" (Xanthosoma cf blandum Schott):

"Aqui se come a folha, se come a folha refogada, como verdura, como se come o dedo dele, cozida como mistura ${ }^{9}$ de café, pode fazer uma sopa, pode fazer uma carne. Nós aqui tinha

\footnotetext{
9 No cotidiano alimentar brasileiro, "mistura" designa "acompanhamento, guarnição". No caso das comunidades quilombolas estudadas neste trabalho, geralmente refere-se ao que acompanha o café (seja na primeira refeição do dia ou no meio da tarde) ou o que acompanha o arroz e o feijão (como por exemplo, carnes em geral) na principal refeição do dia (almoço). De acordo com Cândido (1971) "o feijão, o milho e a mandioca, plantas indígenas, constituem (...) o que se poderia chamar triângulo básico da alimentação caipira, alterado mais tarde com a substituição da última pelo arroz" (p.52). É
} 
muito, minha mãe plantava, minha avó plantava, os mais velho antigamente plantava." (Tida, 63, Pedro Cubas, sobre o "taiá")

Têm-se ainda as etnovariedades utilizadas como condimento, como a "alfavaca" (Ocimum sp. L.), tempero muito cultivado e consumido nas comunidades estudadas:

"É pra tempero, tempero que os antigos usavam na comida (...) Uso, uso, uso bastante. É só pra tempero mesmo de comida... Bom, antigamente a minha avó usava essa semente pra clarear, porque ela tinha problema na vista... Então esse a semente... Essa aqui... Essas são as sementes que nascem. Então quando eles tavam com a vista ruim, assim, antigamente que não tinha, ela pegava este carocinho e colocava no olho pra dormir... Então elas colocavam essa sementinha assim no olho pra dormir. Aí quando era no dia seguinte saía aquela sujeira que tinha, limpa a vista. Falavam que isso aqui era colírio para o olho, porque não tinha antigamente nada, medicamento assim... De farmácia. Então eles usavam muito isso. E ai a gente nunca deixava passar porque, sempre com a semente, ia mudando. Isso aqui é um mato, qualquer lugar que você joga uma semente dela..." (Tina, 63, Pedro Cubas, sobre a "alfavaca")

Já o "cará" (Dioscorea sp. L), além de utilizado para alimentação da família ("um cará bem molinho, que a gente cozinhou e ele tá bem molinho já pra comer" Mora, 59, São Pedro), é também disponibilizado como forragem para a criação:

\begin{abstract}
"Cará também sempre teve, toda vida teve, só que foi coisa que toda vida. A gente planta a batata dele, que é a cabeça que a gente chama, ele dá uns dedo bonito, uns cará bem amarelos, a gente costuma cozinhar pra tomar café... nos tempo dos escravo antigamente quando não tinha... No tempo da pobreza como se diz, quando não tinha, assim, mantimento, eles usavam socar o cará (...) Vai porco também. Naquela época criava muito porco, então a gente ia no mato tirava das planta pro porco comer..." (Tina, 63, Pedro Cubas, sobre o "cará")
\end{abstract}

Eni, 40, São Pedro, fala sobre a "babosa" (Aloe vera (L.) Burm. f.) como etnovariedade para fins medicinais (Apêndice $G$ ): "faz ela batido com leite, conhaque e toma, pra problema de gastrite". Mirabel, 62, Pedri Cubas, descreve o uso do "jarbão" (Verbena officinalis L.): "Jarbão... muito bom pra gripe... chazinho... pra gripe... machucadura... você pega o machucado... você soca ele... põe vinagre...". Tina, 63, Pedro Cubas, descreve os usos das etnovariedades "fedegoso" (Senna sp.), mais utilizado no "tempo dos antigos" e "boldo do Chile" (Peumus boldus Molina), respectivamente:

muito comum que a "mistura" do café refira-se à "taioba" (Xanthosoma cf blandum Schott), ao "cará" (Dioscorea sp.), à "mandioca" (Manihot esculenta Crantz), ou a ainda a itens industrializados, como o pão e a bolacha salgada. As fontes de proteína animal mais comuns nas comunidades referidas são: a carne de caça (várias espécies do gênero Crypturus, como macucos e nhambus; e mamíferos como pacas, cutias, quatis, catetos, queixadas capivaras, veados; e outros animais, como lagartos e tatus), a carne de porco, o frango ou o peixe. 
"Pra remédio. Antigamente, quando os mais velho tinha isso aqui, eles usavam pra dor de cabeça, pra enxaqueca, aquela pessoas que tem aquela dor de cabeça constante? Então eles tiravam essa folha passavam a folha na testa, amarravam um pano, diz que era bom pra tirar calor... E... a semente dele, eles tiravam pra torrar, fazer café. Usava muito, antigamente usava muito... Quando não tinha café. No meu tempo já tinha. Eu nunca tomei. Mas antigamente, muito antigamente, os escravos tomavam muito isso aí como café." (Tina, 63, Pedro Cubas, sobre o "fedegoso")

"Esse aqui é remédio para fígado. Eu conheço pra fígado, porque quando a gente come uma comida que faz mal, bebe alguma coisa que faz mal, muitos mastiga, eu mesmo mastigo a folha dele, nem precisa fazer o chá. Mastigo uma folha dele..." (idem, sobre o "boldo do Chile").

Cida e Eni exemplificam o tipo de atribuição "simbólico-afetiva" a etnovariedades como a "espada de São Jorge" (Sansevieria trifasciata Hort. ex Prain.) "A gente usa ele pra fazer banho de defesa. (...) então usa pra um banho que chama banho de descarga... Então, é usado pra fazer banho de defesa" (Cida, 64, Pedro Cubas), e a "flor de cemitério" ou "coqueiro" (Cordyline sp.) "(...) Como se fosse assim prantando pra não atrair mau olhado (...) Descarrego. Mau-olhado, inveja essas coisas ruins" (Eni, 40, São Pedro). Tina, 63, Pedro Cubas, fala do "guiné" (Petiveria alliacea L.), que não possui uma utilidade prática clara atualmente para algumas famílias estudadas, mas que ainda é bastante cultivado nas comunidades visitadas de maneira geral:

\footnotetext{
"Isso é guiné. Isso aqui eles usavam muito, antigamente, pra fazer remédio, pra dor. Quem tinha problema de reumatismo, então eles faziam, colocavam dentro do álcool... Antigamente não tinha álcool, eles macetavam a parte dela aqui, esquentava no fogo, às vezes nem precisava, é só tirar assim a folha, amassa assim, na mão, coloca dentro de uma garrafa com água, e... Aí quando você vem com isso, nossa. Pior do álcool, cheira longe. Daí passava no lugar que tava doendo. E a raiz dele, naquela época eles faziam muito Guiné na sexta-feira santa, eles usavam a raiz dele pra fazer Guiné, que é uma bebida com pinga. Raspava a raiz... A raiz dele eles rapavam, e punham na pinga pra beber na sexta-feira da paixão. Que diz que era uma... Era o sistema deles antigamente" (Tina, 63, Pedro Cubas, sobre o "guiné").
}

Eni fala sobre o "mandimbé" ou "cipó imbé" (Philodendron cf pinnatifidum Schott), e sua utilização na construção de casas e cercados: "esse aí quando a gente vai na mata tira o cipó dele pra amarrar (...) Chiqueiro pra porco, amarra as casa" (Eni, 40, São Pedro). Gima, 65, Sapatu e Tida, 29, São Pedro, falam sobre a guanxuma (Sida sp.) como material para construção de vassouras: "é, ele é bom... Pra varrer barro"; "nessa época do ano (julho) a gente fica se batendo em tudo lugar pra procurar essa guanxuma pra fazer vassoura". Mora, 59, São Pedro, fala sobre o "coqueiro" (Cordyline sp.) como matéria prima para cercados e a "castanha" (Pachira cf aquatica Aubl.), utilizada para cercados e a produção de esteiras: 
"É coisa muito antiga, que de primeiro os antigos faziam pra cerca. No caso assim, cercar um pedaço só pra poder plantar uma planta, ou deixa a criação presa, daquele lado, daí... Eles faziam cerca" (Mora, 59, São Pedro, sobre o "coqueiro")

"Faz cerca, e também eles tirava pra fazer esteira. Cortava um pedaço dessa grande e põe na água. Quando é quinze dias, tirava aquela fibra. Agora fala fibra, mas falava imbira (...) É, imbira. E daí faz esteira! Fica boa!" (idem, sobre a "castanha").

Nália, 70, Pedro Cubas, fala do "sombreiro" (Terminalia catappa L.), como etnovariedade utlizada principalmente como sombra: "É bom pra gente ficar quando tá sol quente."

Em muitos casos uma única etnovariedade é cultivada para mais de um fim, como relataram algumas informantes: "manjericão a gente usa pra fazer chá bastante (...) e usa também pra cheiro verde na panela" (Eni, 40, São Pedro falando sobre o manjericão - Ocimum basilicum L.); "o abacaxi faz o suco da casca, faz xarope, alguns fazem xarope. Eu não sei fazer, mas, pra quem sabe fazer..." (Tida, 29, São Pedro, sobre o abacaxi - Ananas sp.); "Só pra enfeite também. Eu acho muito bonita a flor dele e bom pra fazer cerca" (Cida, 64, Pedro Cubas, sobre o "fogueteiro" - Malvaviscus arboreus Cav.). Ilício, 52, Sapatu, fala da "banana" (Musa $s p$. L) como etnovariedade também utilizada para artesanato: "eu mesmo não tô usando, porque eu não mexo com artesanato. Mas eles mexe (irmãos). Eles mesmo eles mexe, usa." Abaixo, Cida, 64, Pedro Cubas, descreve o uso da mamona (Ricinus communis L); Tida, 29, São Pedro, fala sobre uma variedade de "maracujá" (Passiflora edulis Sims); Tina, 63, Pedro Cubas, sobre a "goiaba" (Psidium guajava L.); e Tina, 63, Pedro Cubas, fala sobre uma variedade de "laranja" (Citrus sp.), respectivamente:

\footnotetext{
"Isso aqui é mamona. Antigamente, os meus mais velho, minha mãe, meus avós, usavam isso daqui pra fazer azeite (...) é esse aí que fazia dele pra fazer purgante pras pessoa quando tavam doente pra dá de purgante, e muita gente usava no cabelo, muito bom pro cabelo. Só que deixa o cabelo empastado que Deus me livre. Mas os mais velho usavam isso porque num tem coisa melhor pra crescer o cabelo, e melhora o cabelo, quem tem cabelo duro, do que 0 azeite da mamona. Só que é fidido que dói" (Cida, 64, Pedro Cubas, sobre a "mamona")

"Antigamente era pra porco comer, criava muito porco. Então os porco... agora... os passarinho nem dá, as poquinha fruta que dá os passarinho já come antes da gente vê. Mas quando ela dá bastante, o ano passado ela carregou bem, a gente comeu bastante doce." (Tina, 63, Pedro Cubas, sobre a "goiaba")

"Suco... pra venda... até o broto dele é bom pra... às vezes o pessoal tem... eu graças a Deus até agora nunca tive, micose. Às vezes dá micose no corpo das pessoas e esse daí, a plantinha dele, o broto dele, é bom, amassa assim e passa na... no local que tá com ferimento e já..." (Tida, 29, São Pedro, sobre o "maracujá”)
} 
"A folha dela serve pra fazer chá... a casca também... você chupa a laranja, descasca, deixa secar a casca, e faz um chá. Quando não tem a fruta se sua a folha. Mas quando tem a laranja, usa a casca da laranja. Faz chá com alho, limão... alho, laranja e toma com mel... ou com açúcar mesmo... Pra assim... constipação no peito. É um remédio dos antigo, que eles também não tinham remédio." (Tina, 63, Pedro Cubas, sobre a "laranjeira")

A Figura 4.20 mostra as freqüências absolutas e em porcentagem das 4 categorias de uso (alimentação, ornamentação, medicinais, e simbólico-afetivo) que congregam a maior riqueza de etnovariedades cultivadas no espaço dos jardinsquintal para as comunidades de Sapatu, Pedro Cubas e São Pedro.

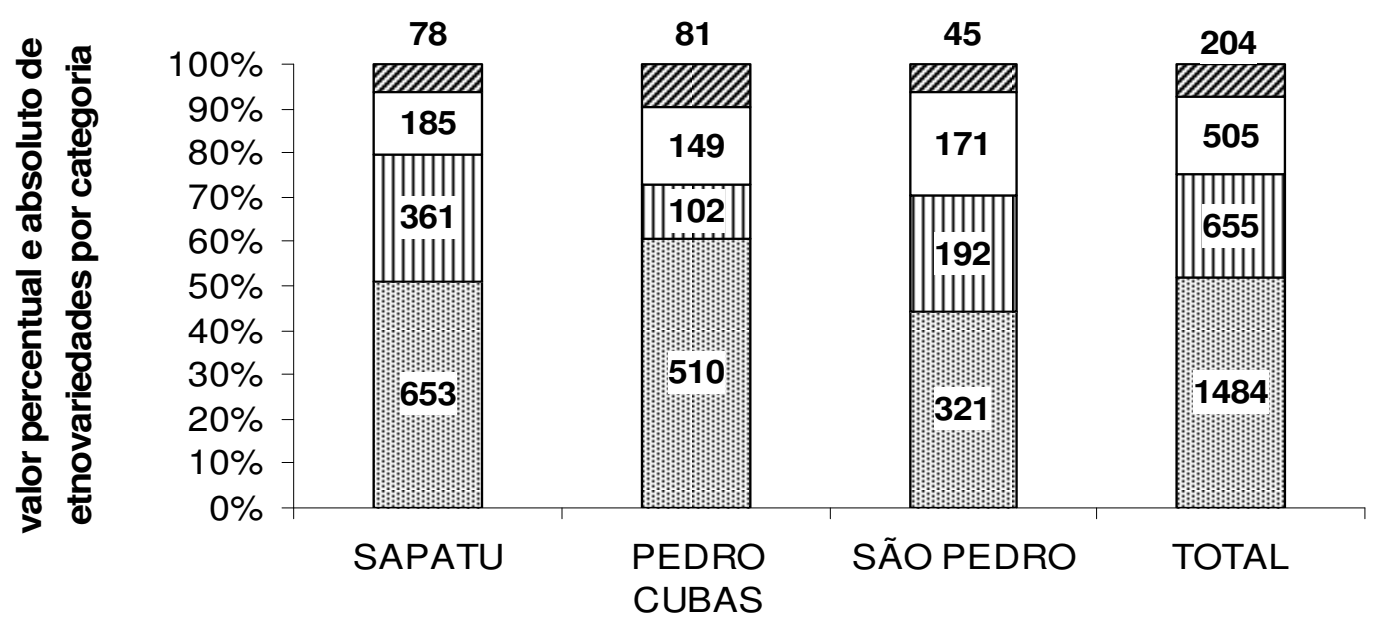

comunidades

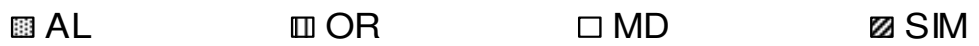

Figura 4.20: categorias de uso que congregam maior abundância de etnovariedades cultivadas no espaço dos jardins-quintal para as comunidades de Sapatu, Pedro Cubas e São Pedro (AL = ornamental; OR = ornamental; $\mathbf{M D}=$ medicinal; $\mathbf{S I M}=$ simbólico-afetiva $)$

As comunidades foram comparadas entre si com relação à distribuição de etnovariedades mais freqüentemente reportadas por categoria de uso. Como essas contagens também não possuem uma distribuição normal, foi adotado também o teste de Kruskal-Wallis (Tabela 4.4). As comunidades de Sapatu, Pedro Cubas e São Pedro são estatisticamente diferentes entre si com relação às etnovariedades com função medicinal $(H=0,6 ; G L=2 ; p=0,022)$ e as com função estética $(H=20,88 ; G L=2 ; p=0,000)$. Novamente Pedro Cubas e São Pedro apresentaram maiores diferenças entre si com relação a esses parâmetros (Tabela 4.4). 
Tabela 4.4 teste não paramétrico de Kruskal-Wallis para etnovariedades distribuídas nas diferentes categorias de uso da vegetação dos jardins-quintal ( $O$ símbolo * indica diferença significativa), ao nível de significância de 5\%. (continua).

COMUNIDADES

\section{Sapatu Pedro Cubas São Pedro}

\begin{tabular}{ccccc} 
categorias de uso & Kruskal-Wallis & $\mathrm{n}=30$ & $\mathrm{n}=27$ & $\mathrm{n}=14$ \\
\hline & mediana & 18 & 14 & 24 \\
& rank médio & 38,4 & 31,8 & 39 \\
alimentares & $\mathbf{Z}$ & 0,84 & $-1,36$ & 0,61 \\
\cline { 2 - 5 } & $\mathbf{H}$ & & 1,85 & \\
$\mathbf{D F}$ & & 2 & \\
$\mathbf{p}$ & & 0,396 & 9 \\
& mediana & 6 & 5 & 49,2 \\
rank médio & 34,5 & 30,8 & 2,67
\end{tabular}

medicinais

\begin{tabular}{cc}
\hline $\mathbf{H}$ & 7,6 \\
$\mathbf{D F}$ & 2
\end{tabular}

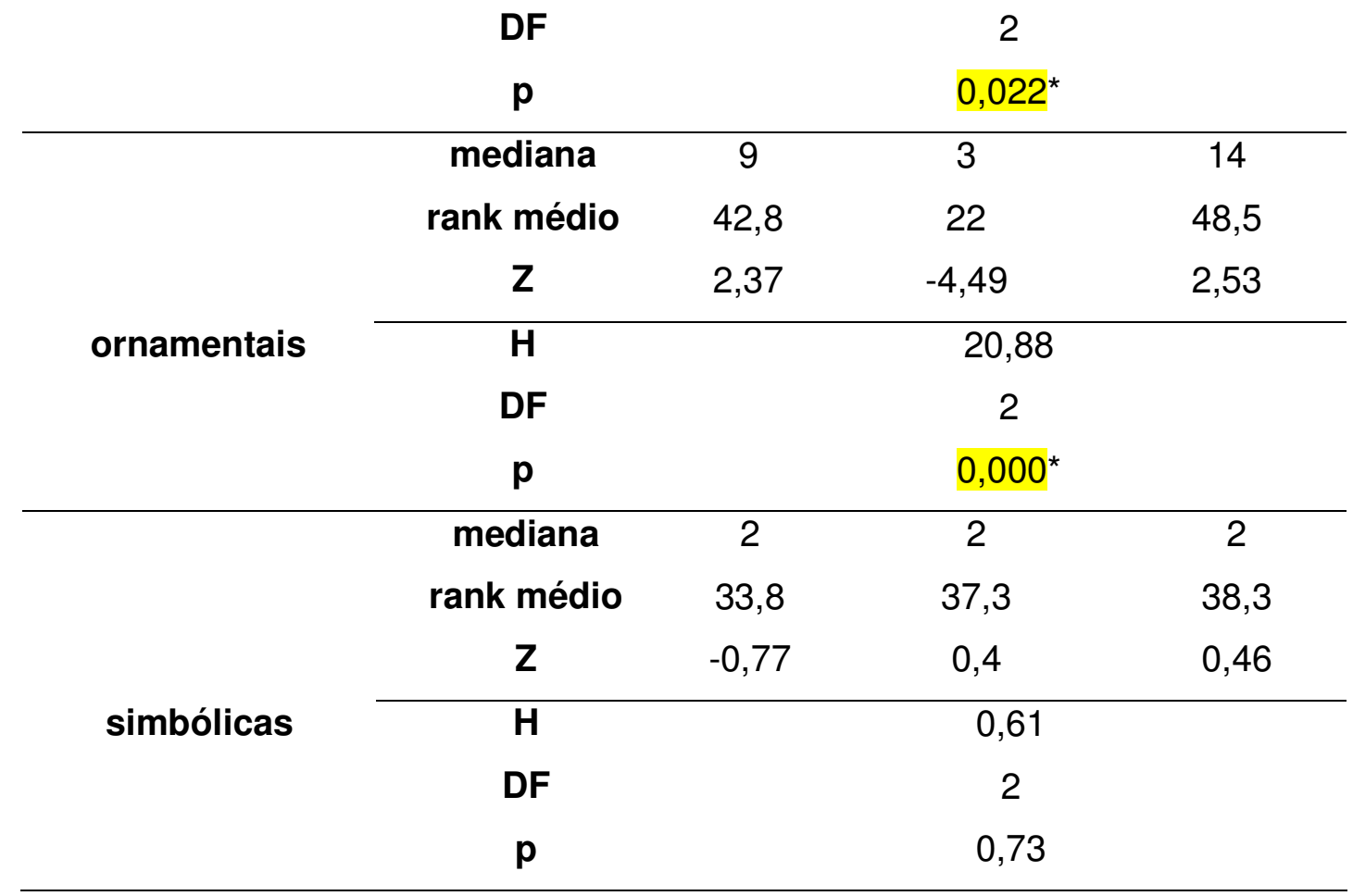




\subsection{Manejo: plantio, cultivo, manutenção e trocas}

Com relação ao manejo, as mulheres são as principais responsáveis pelo plantio e manutenção dos jardins-quintal (Figuras 4.21). Dos 71 levantamentos realizados, $88,73 \%$ ( $n=63$ ) foram acompanhados por informantes mulheres, que demonstraram grande intimidade e conhecimento sobre os cultivares. Elas são responsáveis, em média, pelo plantio de 60,47\% (Figura 4.21) das etnovariedades presentes na área estudada. Dessas, $16,76 \%$ das plantas mantidas e utilizadas nos jardins-quintal nasceram espontaneamente, ou seja, não houve plantio (Figura 4.21). Apenas $12,32 \%$ dos cultivares desse espaço foram plantados pelo cônjuge do informante (Figura 4.21). O restante, $10,40 \%$ das etnovariedades, é herança de antigos moradores da UD (na maioria das vezes parentes próximos como pais, avós e bisavós), ou foram plantados pelos filhos, irmãos, cunhados, netos ou sogros da informante. A variação entre as comunidades com relação ao responsável pelo plantio das variedades dos jardins-quintal foi avaliada através do teste nãoparamétrico de Kruskal-Wallis. A diferença entre as medianas se mostrou significativa apenas com relação ao número de etnovariedades plantadas pelo informante, sendo que as comunidades que apresentaram maior distinção entre si foram novamente Pedro Cubas e São Pedro ( $H=8,43 ; G L=2 ; p=0,015)$ (Tabela 4.5).

Tabela 4.5: teste não paramétrico de Kruskal-Wallis para responsável pelo plantio de etnovariedades. O símbolo * indica diferença significativa, ao nível de significância de 5\%. (continua).

\begin{tabular}{ccccc}
\hline \multirow{2}{*}{$\begin{array}{c}\text { Kesponsável pelo } \\
\text { plantio }\end{array}$} & Kruskal- & & Pedro & São \\
& Wallis & Sapatu & Cubas & Pedro \\
& & $\mathrm{n}=30$ & $\mathrm{n}=27$ & $\mathrm{n}=14$ \\
\hline & mediana & 25,5 & 14 & 33 \\
& rank médio & 38 & 27,1 & 45,7 \\
informante & Z & 0,91 & $-2,66$ & 2,09 \\
\cline { 2 - 5 } & H & & 8,43 & \\
& DF & & $0,015^{*}$ & \\
\hline
\end{tabular}


Continuação da Tabela 4.5: teste não paramétrico de Kruskal-Wallis para responsável pelo plantio de etnovariedades. O símbolo * indica diferença significativa, ao nível de significância de $5 \%$. (continua).

\begin{tabular}{|c|c|c|c|c|}
\hline \multirow{3}{*}{$\begin{array}{c}\text { responsável pelo } \\
\text { plantio }\end{array}$} & \multirow[b]{2}{*}{ Kruskal- } & \multicolumn{3}{|c|}{ COMUNIDADES } \\
\hline & & & & São \\
\hline & Wallis & Sapatu & Pedro Cubas & Pedro \\
\hline \multirow{6}{*}{ nascimento espontâneo } & mediana & 5,5 & 4,5 & 7 \\
\hline & rank médio & 34,1 & 33,6 & 41,9 \\
\hline & $\mathbf{Z}$ & $-0,48$ & $-0,6$ & 1,32 \\
\hline & $\mathbf{H}$ & & 1,76 & \\
\hline & DF & & 2 & \\
\hline & $\mathbf{p}$ & & 0,413 & \\
\hline \multirow{6}{*}{ cônjuge } & mediana & 3 & 2 & 0 \\
\hline & rank médio & 38,7 & 35,4 & 28,9 \\
\hline & $\mathbf{Z}$ & 1,13 & $-0,03$ & $-1,36$ \\
\hline & $\mathbf{H}$ & & 2,2 & \\
\hline & DF & & 2 & \\
\hline & $\mathbf{p}$ & & 0,310 & \\
\hline
\end{tabular}




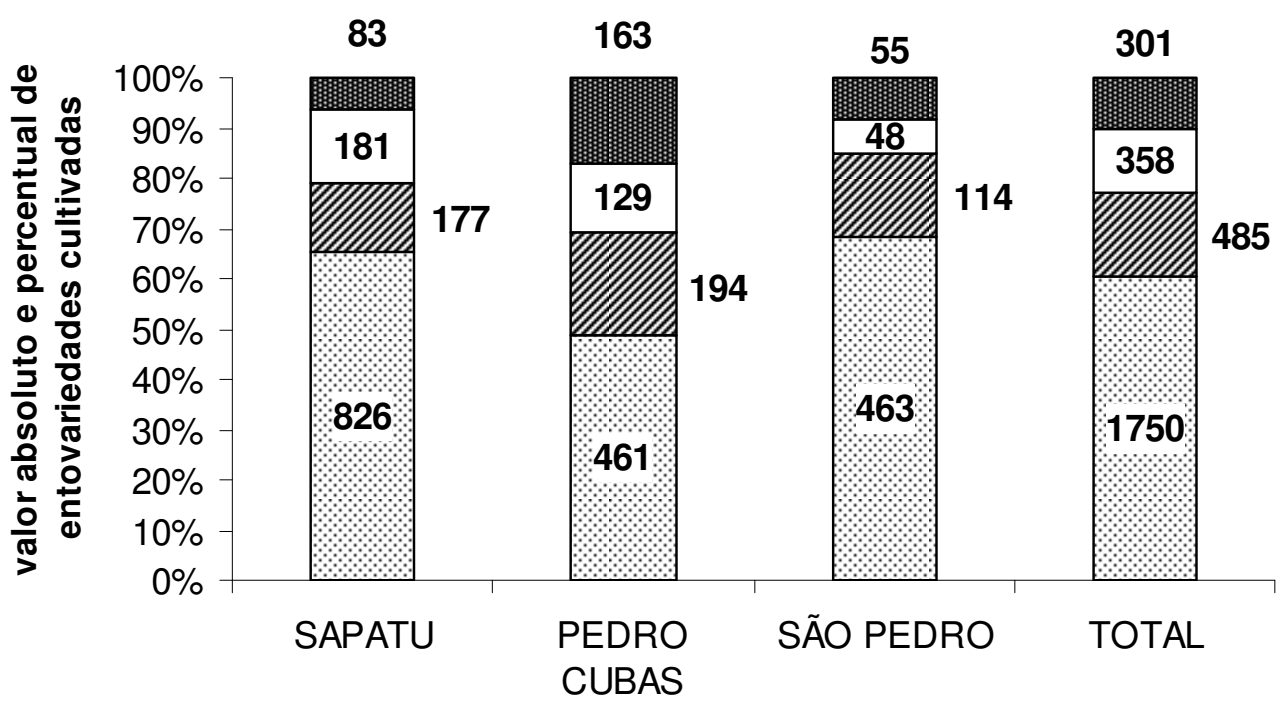

comunidades

圈 informante nascimento espontâneo $\square$ cônjuge $\quad$ 畻 outros

Figura 4.21 principais responsáveis pelo plantio de etnovariedades nos jardins-quintal das comunidades quilombolas Sapatu, Pedro Cubas e São Pedro

Além do importante trabalho nos jardins-quintal, as mulheres inevitavelmente auxiliam nas roças próximas, e menos freqüentemente, nas longínquas (conhecidas geralmente como "capuovas"). Em alguns casos, são elas as principais responsáveis também por estas áreas de roça - além de cuidar da casa e dos filhos. Apesar disso, das 55 informantes mulheres questionadas a esse respeito, $54,54 \%(n=38)$ reportaram a ajuda mais ou menos freqüente do cônjuge para a manutenção dos jardins-quintal. Cerca de $54 \%$ ( $n=38$ ) dos 71 informantes (homens e mulheres) disseram contar com algum tipo de ajuda, seja dos filhos, pais, parentes agregados, ou pagam diárias como auxílio para o cuidado com estes espaços, embora a última situação seja pouco freqüente (Figura 4.22). 


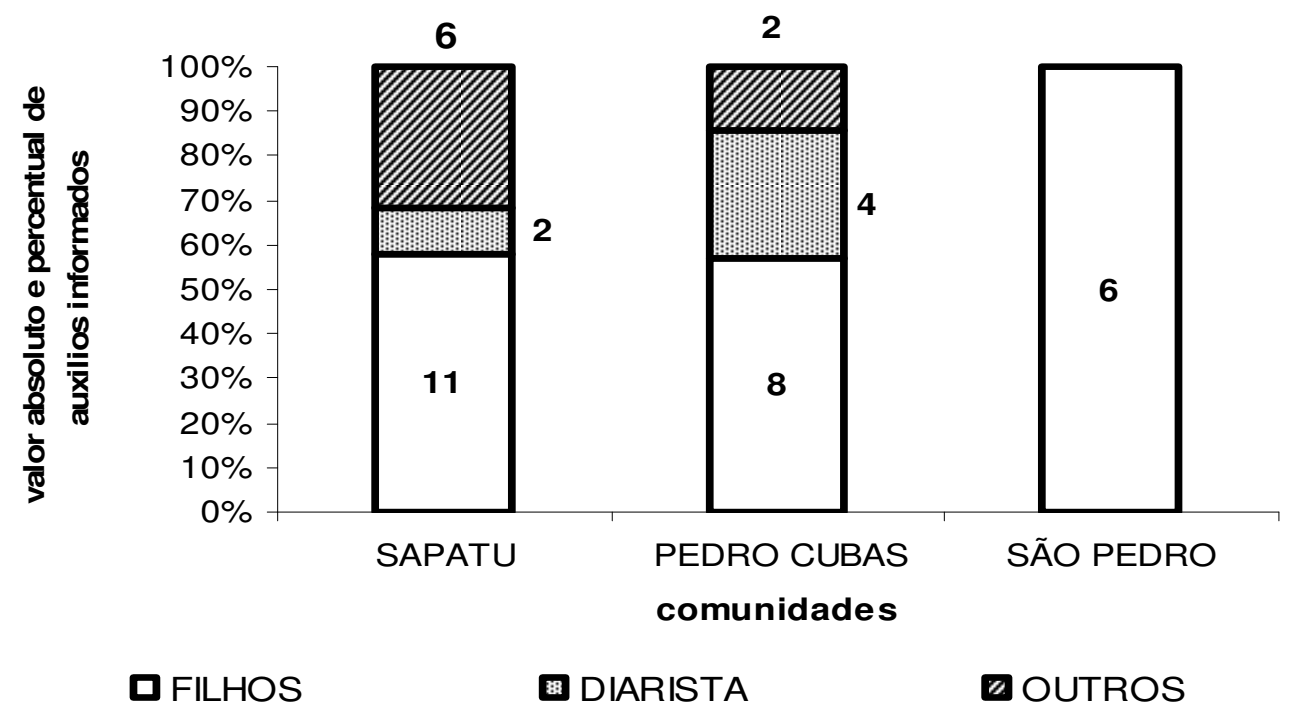

Figura 4.22: auxílios alternativos à ajuda do cônjuge para o manejo dos jardinsquintal nas comunidades quilombolas de Sapatu, Pedro Cubas e São Pedro $(n=38)$

Sobre sua rotina diária, as mulheres relataram:

\begin{abstract}
"Meu Deus do céu, a rotina principalmente de manhã é boca quente. Levanta de manhã tem que cuidar dos porco, da comida pras galinha, já levanta vai lavar uma louça, vem varre casa, faz comida, já tem o tamborzinho de roupa esperando pra lavar. Quando meu marido leva comida, bem, de manhã 6 hora eu já tô em pé pra tá fazendo a marmita dele. Aí quando ele não leva, dia que ele cisma de não levar, eu faço o almoço e levo lá no serviço dele. Porque daqui mais lá dá $1 \mathrm{~km}$ ou mais. Aí vou e volto a pé. Então minha rotina é essa daí. Aí, às vezes quando tem um tempinho vou lá na roça, também, trabalho direto, quando eu to mais ou menos desocupada eu vou, planto alguma coisinha" (Vânia, 26, Pedro Cubas)
\end{abstract}

"Acordo cedo aproveito cedo pra mim ir pra roça, aproveitar o tempo fresco pra depois, quando chego faço outra coisa (...) Arrumo as criança, faço a comida, dou comida, mando tomar banho, arrumo eles pra ir pra escola (...) Daí depois do almoço, se não tiver muito quente, eu volto pra roça de novo (...) Quando tá muito quente eu fico em casa, lavo uma roupa, faço uma coisa, faço outra" (Sebastiana, 60, Pedro Cubas).

"A gente acorda cedo daí a gente cuida da casa, faz comida, vai trabalhar pra longe, precisa vim almoçar, precisa do almoço tudo pronto, lava a roupa, cuida das criança que estão estudando e... Cuida da horta das coisa perto de casa, quando não dá pra trabalhar na roça bem longe fica cuidando de casa mais perto." (Sandra, 54, São Pedro).

Como se pode observar, o período do dia dedicado ao manejo do jardim-quintal e a freqüência com que esse manejo ocorre, varia conforme a rotina do principal responsável pelo espaço.

Normalmente existem quatro estratégias empregadas nos cuidados com 0 espaço dos jardins-quintal. São eles: a utilização de zonas de manejo (ver subseção 
4.2.2), a regulação da água e da umidade, a melhoria nutricional do solo ou controle de pragas, e a tendência geral de manter - e se possível aumentar - a diversidade florística de espécies. Cerca de $82 \%$ (58) dos entrevistados disseram irrigar o solo, sendo tal procedimento, no entanto, reservado predominantemente a cultivares recém-plantados e as áreas de horta. Com relação à fertilização do solo do espaços dos jardins-quintal, 40,84\% (29) dos informantes reportaram utilizar algum tipo de insumo ou técnica agrícola para melhoria nutricional do solo ou para controle de pragas. Foram citados o uso de adubo orgânico (geralmente esterco de boi ou de galinha), cinzas de folhas, formicida granulado, calcário, óleo para controle de pragas em banana e até a queimada no terreno:"a gente coloca adubo assim de boi, essas coisa, a gente pega no pasto, por causa da verdura. E aquele calcário a gente põe pra amolece a terra" (Sandra, 54, São Pedro)

Com relação ao plantio, a procedência das sementes e mudas das etnovariedades cultivadas no espaço dos jardins-quintal variou entre as 6 categorias principais (Figura 4.23), por ordem de relevância: vizinhança (moradores com parentesco distantes ou sem parentesco com o informante, ou em ruas próximas), com 21,97\% ( $n=581)$ das etnovariedades cultivadas; antigos (avós ou até bisavós do informante ou do antigo morador da residência), com 13,88\% ( $n=367)$ dos cultivos; as nascidas espontaneamente, com 13,61\% ( $n=360)$; as provenientes da mata local (trazidas pelo informante, pelo cônjuge ou por qualquer outro responsável pelo plantio), com $12,55 \%$ ( $n=332$ ); as provenientes de outras comunidades (conseguidas com parentes próximos, distantes, e até desconhecidos), com 7,14\% das contagens $(n=189)$; e as conseguidas com outros parentes da comunidade, que não os pais, filhos ou sogros do informante, com 6,54\% das contagens $(n=173)$ (Figura 4.23). Com representatividade menos relevante e não constando da Figura 4.23, ainda, estão as etnovariedades compradas (com $n=137$ contagens, ou 5,18\%), as conseguidas com os pais do informante (104 contagens, 3,93\%), as provenientes das áreas de roça próximas ou longínquas ( $n=83$ contagens, 3,13\%). Por fim, com os $12,03 \%$ ( $n=318$ contagens) restantes, estão as etnovariedades conseguidas em projetos comunitários governamentais e não governamentais; com o Instituto de Terras de São Paulo (ITESP) - órgão bastante atuante na região; em outras cidades; no trabalho realizado em fazendas ou casas de família; ou, por fim, com desconhecidos que passam pelo bairro ou que são encontrados em centros urbanos 
Tabela 4.6: teste não paramétrico de comparação de medianas (Kruskal-Wallis) das contagens relativas às principais categorias de procedência de sementes e mudas das etnovariedades cultivadas nos jardins-quintal. $O$ símbolo * indica diferença significativa, ao nível de significância de 5\%..

COMUNIDADES

procedência Kruskal-Wallis Sapatu Pedro Cubas São Pedro

\begin{tabular}{|c|c|c|c|c|}
\hline & & $n=30$ & $n=27$ & $n=14$ \\
\hline \multirow{6}{*}{ vizinhança } & mediana & 7 & 3,5 & 12,5 \\
\hline & rank médio & 39,6 & 22,9 & 50 \\
\hline & $\mathbf{z}$ & 1,47 & $-3,97$ & 2,98 \\
\hline & $\mathbf{H}$ & & 18,23 & \\
\hline & DF & & 2 & \\
\hline & $\mathbf{p}$ & & $0,000^{*}$ & \\
\hline \multirow{9}{*}{ antigos } & mediana & 5 & 1,5 & 1,5 \\
\hline & rank médio & 40,5 & 29,9 & 35,2 \\
\hline & $\mathbf{z}$ & 1,77 & $-1,77$ & $-0,06$ \\
\hline & $\mathbf{H}$ & & 3,77 & \\
\hline & DF & & 2 & \\
\hline & $\mathbf{p}$ & & 0,152 & \\
\hline & mediana & 3 & 3,5 & 3,5 \\
\hline & rank médio & 36 & 35,2 & 35 \\
\hline & $\mathbf{z}$ & 0,17 & $-0,09$ & $-0,1$ \\
\hline
\end{tabular}

nascimento

espontâneo

H $\quad 0,03$

\begin{tabular}{ccccc} 
DF & \multicolumn{3}{c}{2} \\
$\mathbf{p}$ & \multicolumn{3}{c}{0,986} & \\
\hline mediana & 4 & 2 & 4 \\
mata local & rank médio & 35,8 & 32,7 & 40 \\
& $\mathbf{z}$ & 0,11 & $-0,88$ & 0,93 \\
& H & & 1,17 & \\
& DF & & 2 & \\
\hline
\end{tabular}


Por fim de $79,71 \%$ ( $n=55$ contagens para um $n$ total de 69 ) informantes declararam haver dificuldades para o cultivo de plantas no espaço dos jardinsquintal. Os principais problemas citados para tal (Figura 4.24) foram: as formigas, citadas por 49,27\% $(n=34)$ dos informantes; terra infértil $14,49 \% \quad(n=10)$ dos informantes; pragas em geral, citadas por 13,04\% $(n=9)$ dos informantes; terra seca, citada por 13,04\% ( $n=9)$ dos informantes; problemas com a própria criação de animais citada por $10,14 \%(n=7)$ dos informantes) Também foram citadas terra compactada, por 7,25\% $(n=5)$ dos informantes; terra muito úmida, citadas por 1,45\% $(n=1)$ dos informantes; as épocas de seca, citada por 1,45\% $(n=1)$ das UDs; e problemas com a criação da vizinhança, citadas por $1,45 \%(n=1)$ dos informantes; como fatores menos relevantes. Nas palavras dos próprios informantes: "o problema aqui que eu não faço questão de tá plantando muito, porque a galinha mexe. O pato também, o pato pega tudo que é verde e belisca" (Celina, 40 anos, São Pedro). "O que não dava pra plantar lá é verdura porque a galinha come (...) As galinha da (...) comeu tudo que o rapaz dali plantou lá" (Nazareno, 58 anos, Pedro Cubas)

\footnotetext{
"Há uns tempo eu fiz uma horta ali mas as formiga não deixa, acabaram com tudo. Não deixa para nada, a gente planta, pode planta hoje a muda de planta, quando amanhece você olha não tem nada, ta chão puro. Não deixa parar nada. (...)" (Dina, 36, Pedro Cubas)

"O probrema que tem aqui que atrapalha o crescimento das plantas, não só as plantas de jardim como da roça, é as formiga. É só formiga, porque a formiga quando ela dá aí..." (Cida, 64, Pedro Cubas).
} 


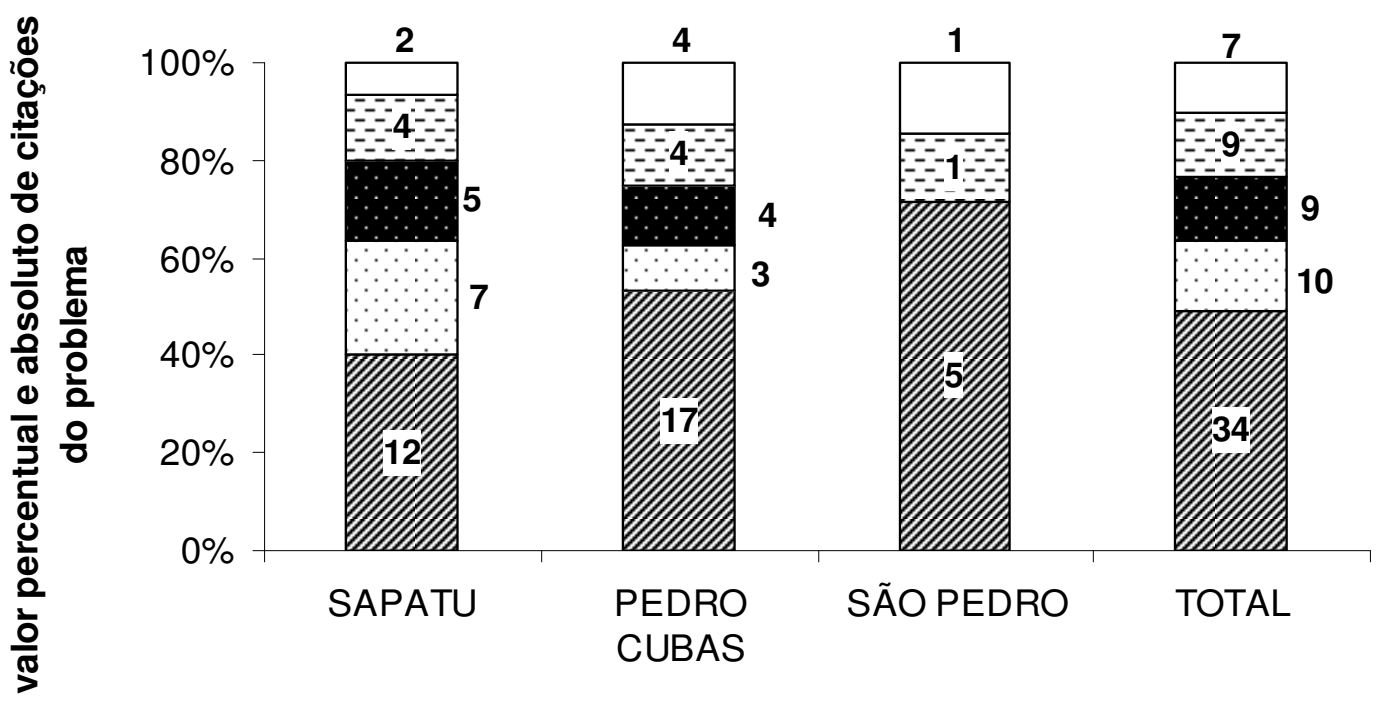

comunidades

\section{formiga \\ $\square$ terra inapropriada \\ - outras pragas \\ 曰 terra seca \\ $\square$ própria criação}

Figura 4.24: principais problemas enfrentados para o cultivo no espaço dos jardins-quintal das comunidades quilombolas de Sapatu, Pedro Cubas e São Pedro

\subsection{Criação de animais}

Dentre os animais mantidos e manejados no espaço dos jardins-quintal, os mais comuns entre as três comunidades estudadas são: os cães, encontrados em $73,24 \%$ das UDs ( $n=52$ de 71), e utilizados para a caça e auxilio nas incursões dentro da mata fechada; os galináceos, encontrados em $71,83 \%$ das UDs $(n=51$ de 71), e utilizados para alimentação da família e, uma pequena porção, para a venda; os gatos, encontrados em $46,48 \%$ das UDs ( $n=33$ de 71 ), e mantidos principalmente para o controle dos ratos; os porcos, encontrados em 19,71\% das UDs ( $n=14$ de 71$)$, e utilizados na alimentação da UD e, uma pequena porção, para a venda; os patos, encontrados em 15,49\% das UDs ( $n=11$ de 71 ), e utilizados para alimentação da família e, uma pequena porção, para a venda; e os bovinos, encontrados em 11,26\% das UDs ( $n=8$ de 71) (Figuras 4.25 e 4.26). Outros animais, como pequenos pássaros de espécies diversas, gansos, patos, perus, coelhos, abelhas, preás e galinhas d'angola também foram encontrados. Animais como bois, burros e cavalos 
foram reportados como parte da unidade de produção, mas geralmente são mantidos em pastos e/ou áreas que não fazem parte da unidade jardim-quintal. Sobre a criação de gatos e cachorros discorre Carla, 22, Pedro Cubas:

"O gato é por causa do rato, pra não devorar a lavoura da gente, milho, arroz que nóis sempre planta e o cachorro é por causa de bicho do mato, cobra. Tando assim no terreiro late ele espanta um pouco" (Carla, 22, Pedro Cubas).

"o gato ele tem um valor assim, antigamente tinha, plantavam bastante quantidade de arroz, milho, e o rato judiava bastante, então o gato pegava o rato. Então pessoal tinha bastante gato por causa disso. Cachorro... Compania de casa..." (Tida, 29, São Pedro). 

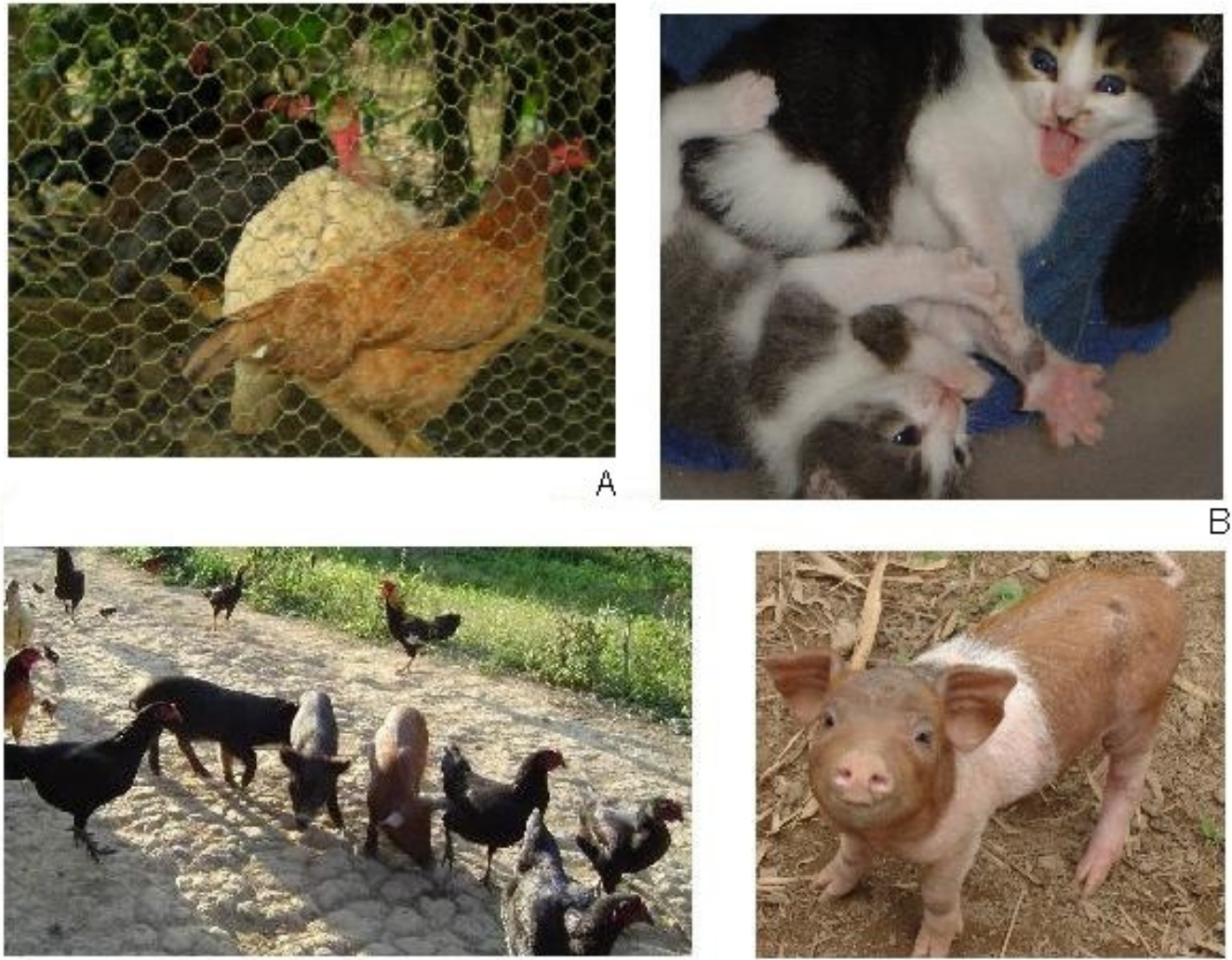

C
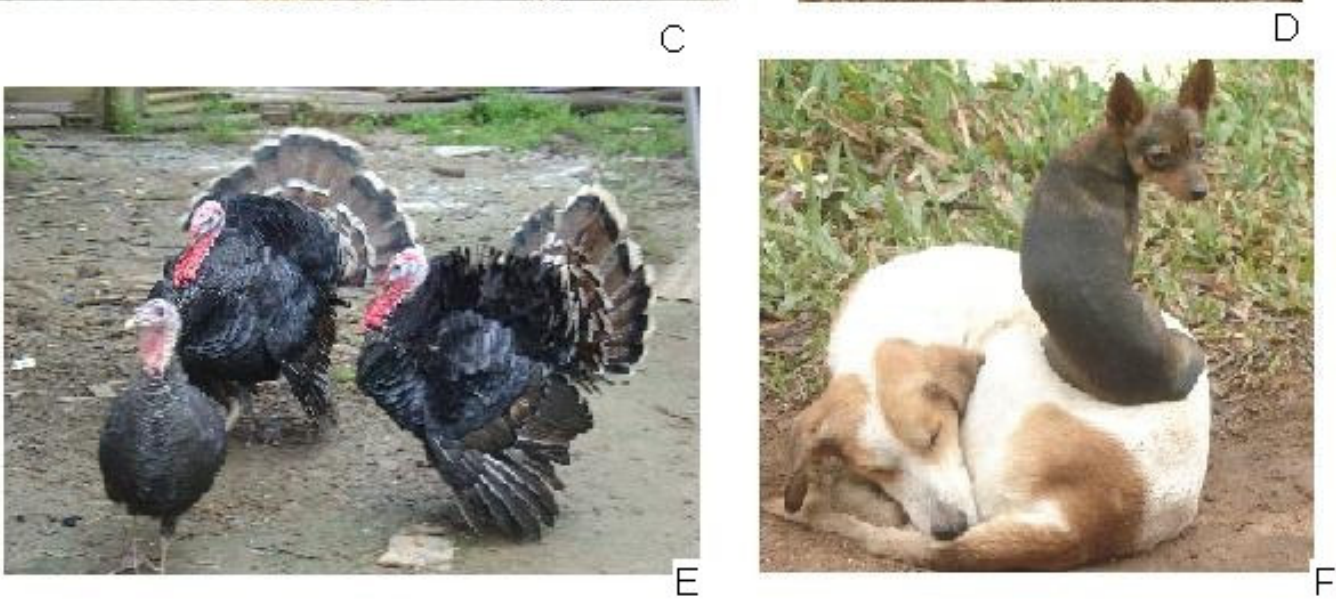

Figura 4.25: principais animais criados no espaço dos jardins-quintal das comunidades quilombolas de Sapatu, Pedro Cubas e São Pedro (A: galinhas; B: gatos; C: galinhas e porcos; D: porco; E: perus; F: cães) 

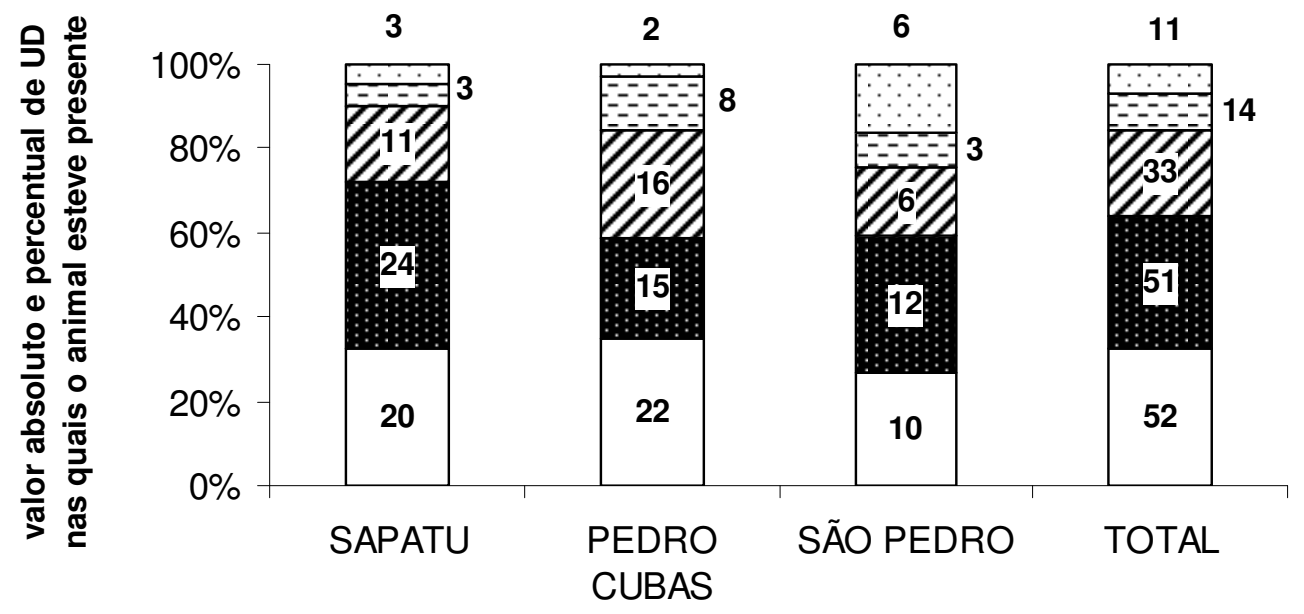

comunidades

\section{cachorros galinhas $\square$ gatos $\boxminus$ porcos $\square$ patos}

Figura 4.26: ocorrência dos animais criados nos espaços dos jardins-quintal das comunidades quilombolas de Sapatu, São Pedro e Pedro Cubas

Além da freqüência de distribuição, os mesmos animais também foram investigados com relação ao número de indivíduos (Figura 4.27). A presença desses animais nos jardins-quintal mostrou freqüências com distribuição não-normal, por isso, para fins comparativos, foi utilizado o teste não-paramétrico de Kruskal-Wallis (Tabela 4.7). Foram encontradas diferenças significativas entre as comunidades apenas com relação aos cães (sendo Sapatu e Pedro Cubas os mais diferentes entre si) ( $H=13,08 ; G L=2 ; p=0,001)$, gatos (idem) $(H=7,31 ; G L=2 ; p=0,026)$ e os patos ( $h=7,06 ; G L=2 ; p=0,029$ ) (sendo Pedro Cubas e São Pedro os mais diferentes) 


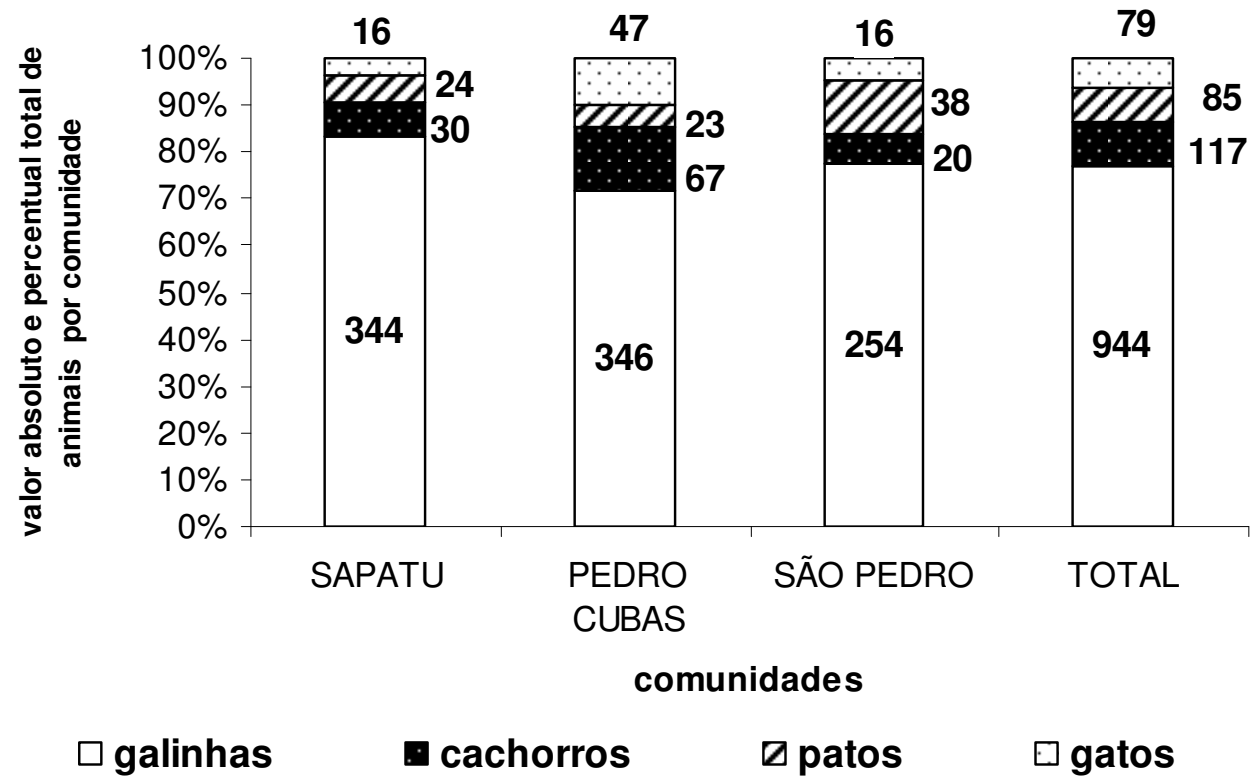

Figura 4.27: abundância numérica dos animais criados no espaço dos jardinsquintal nas comunidades quilombolas de Sapatu, São Pedro e Pedro Cubas

Tabela 4.7: teste não paramétrico de comparação de medianas (Kruskal-Wallis) das contagens relativas aos animais mais criados no espaço nos jardins-quintal. $O$ símbolo * indica diferença significativa, ao nível de significância de 5\%. (continua).

\section{COMUNIDADES}

Animal Kruskal-Wallis Sapatu Pedro Cubas São Pedro

\begin{tabular}{|c|c|c|c|c|}
\hline & & $n=30$ & $n=27$ & $n=14$ \\
\hline \multirow{6}{*}{ cães } & mediana & 1 & 2 & 1 \\
\hline & rank médio & 26,1 & 45,4 & 33 \\
\hline & $\mathbf{Z}$ & $-3,12$ & 3,46 & $-0,3$ \\
\hline & $\mathbf{H}$ & \multicolumn{3}{|c|}{13,08} \\
\hline & DF & \multicolumn{3}{|c|}{2} \\
\hline & $p$ & \multicolumn{3}{|c|}{$0,001^{*}$} \\
\hline \multirow{6}{*}{ gatos } & mediana & 0 & 2 & 0 \\
\hline & rank médio & 28,5 & 41,9 & 34,1 \\
\hline & $\mathbf{Z}$ & $-2,22$ & 2,35 & $-0,08$ \\
\hline & $\mathrm{H}$ & \multicolumn{3}{|c|}{7,31} \\
\hline & DF & \multicolumn{3}{|c|}{2} \\
\hline & p & \multicolumn{3}{|c|}{$0,026^{\star}$} \\
\hline
\end{tabular}


Continuação da Tabela 4.7: teste não paramétrico de comparação de medianas (Kruskal-Wallis) das contagens relativas aos animais mais criados no espaço nos jardins-quintal. O símbolo * indica diferença significativa, ao nível de significância de $5 \%$.

\begin{tabular}{|c|c|c|c|c|}
\hline \multirow{6}{*}{ galináceos } & mediana & 10,5 & 14 & 15 \\
\hline & rank médio & 32,9 & 31 & 38,3 \\
\hline & $\mathbf{Z}$ & $-0,04$ & $-0,67$ & 0,95 \\
\hline & $\mathbf{H}$ & & & \\
\hline & DF & & & \\
\hline & p & & & \\
\hline \multirow{6}{*}{ patos } & mediana & 0 & 0 & 0 \\
\hline & rank médio & 32,5 & 31,8 & 42,4 \\
\hline & $\mathbf{Z}$ & $-0,59$ & $-0,7$ & 1,64 \\
\hline & $\mathbf{H}$ & \multicolumn{3}{|c|}{7,06} \\
\hline & DF & \multicolumn{3}{|c|}{2} \\
\hline & p & \multicolumn{3}{|c|}{$0,029^{*}$} \\
\hline \multirow{6}{*}{ porcos } & mediana & 0 & 0 & 0 \\
\hline & rank médio & 30,9 & 38,7 & 35,1 \\
\hline & $\mathbf{Z}$ & $-1,38$ & 1,33 & 0,12 \\
\hline & $\mathbf{H}$ & \multicolumn{3}{|c|}{4,34} \\
\hline & DF & \multicolumn{3}{|c|}{2} \\
\hline & $p$ & \multicolumn{3}{|c|}{0,114} \\
\hline
\end{tabular}


O cuidado com a criação envolve basicamente atividades como a alimentação e a eventual aplicação de medicamentos, que podem ser tanto naturais (produzidos na própria UD ou coletadas na mata próxima) como industrializados comprados em mercados próximos. Geralmente não é gasto nem muito tempo nem muito dinheiro com os animais enfermos, já que cães, gatos e galinhas são obtidos facilmente, sem custo algum, junto à vizinhança. Cães e gatos são alimentados com sobras de comida (arroz e feijão comprados no mercado, principalmente) e, eventualmente, ração. Os galináceos são alimentados com milho e arroz cuja maior parcela é comprada em mercados de centros urbanos próximos, e de banana, inhame e mandioca, todos vindos da lavoura da UD. Os porcos são geralmente alimentados com farelo de trigo, ração e milho comprados no mercado, e de banana, mandioca, cana e abóbora vindos da lavoura (roças próximas ou capuova).

A diversidade e quantidade de animais criados por essas populações quilombolas vêm decaindo ao longo dos anos. A maioria dos informantes, 95,77\% $(\mathrm{n}=68)$, reportaram que seus pais e avós costumavam ter muito mais "criação" nos "terreiros" e nas "capuovas". Sobre isso, coletamos alguns relatos, como de seu Nazareno,58 anos, morador de Pedro Cubas: "Cavalo cada um tinha 1, 2, 3 cavalo. Porcada. Era difícil quem não tinha porco por aqui. Minha mãe mesmo criou por aqui".

Os principais motivos declarados pelos entrevistados para esse processo de simplificação e diminuição da produção de proteína animal pelas comunidades locais são diversos. Dentre os mais significativos foram citados, em primeiro lugar, a proximidade entre as residências (configuração resultante do processo de formação das vilas devido a necessidades de acesso a centros escolas e tratamento médico, e outras oportunidades trabalho), reportado por $47,88 \%(n=34)$ dos informantes. Com a aproximação das UDs, perde-se mais tempo (para prender e soltar os animais, e reparar danos à propriedade dos vizinhos e ao próprio cultivo) e mais dinheiro (com o investimento em cercados e reparação dos danos). O segundo motivo, citado por $21,12 \%(n=15)$ dos entrevistados, foi a falta de lavoura para o plantio de cultivares destinados à alimentação da criação:

"Daquele tempo só saciava um porco, uma galinha só com milho, só com a lavagem da panela que dava com a comida, com verdura cozida como naqueles tempo com bastante cará, bastante banana, bastante abóbora, as pessoa criavam mais as criação com essas coisa. Então era tudo 
coisa nativo da terra, coisa pura, e agora hoje a maior parte da criação vai criar, ninguém tem mais roça de milho pra criar um porco" (Cida, 64, Pedro Cubas).

“(...) Porque a criação antigamente, eles eram tratado com o alimento da roça. Não é como agora comprado que nem a gente compra. Era milho... Agora a gente compra" (Francisca, 65, Pedro Cubas)

"(...) Eles (...) usava serviço de roça plantava um milho, plantava um arroz, tinha porco, galinha, pato, ganso, marreco (...). Porque a pessoa plantava a planta já, num tinha que comprar em lugar nenhum, tiravam dali mesmo. Do meu tempo do meu pai mesmo nós tinha de 10,12 porco (...) e daí quando quiria matar um porco pinchava em cima do primeiro, secava aquela carne e punhava ali no feijão, ou no arroz mesmo, o modo que desse pra cozinhar, tinha mistura... E hoje é difícil porque hoje os homem... Tá difícil porque a gente vai criar porco no meio da comunidade num tem como criar um porco solto, e se cria ele sem cumida, ai é pior. Porque o mantimento tá muito caro, precisa tá comprando." (Zico, 70. São Pedro)

"Ah, meu pai tinha uma porcada... Uma época ele tinha, antes num tinha essas fazenda de banana (...) antes as banana que plantava era só pras criação, ele plantava os milho pras galinha. Tinha os porco também que ele cuidava, dava milho, dava banana... Criava cada porco bonito, tudo mês ele matava um porco sabe. Mas só pra gasto de casa também." (Mirna, 67, Sapatu)

A falta de lavoura para o plantio foi amplamente relacionado à restrição do uso do solo, através das leis ambientais de proteção das Unidades de Conservação dentro das quais as comunidades em questão estão inseridas. A manutenção dos animais passa, então, a ser ainda mais desvantajosa e cara. Como terceiro e mais relevante problema foi reportado o desinteresse das novas gerações pelas atividades agrícolas em geral, citado por 12,67\% (n=9) das 71 famílias. Foram, ainda, citadas as leis de vigilância sanitária (que impõe uma série de restrições à manutenção dos animais domésticos), a perda da "tradição" (conhecimento e prática) e o crescente envolvimento com atividades não agrícolas (como prestação de serviços terceirizados a prefeituras, atividades relacionadas ao turismo, ao comércio, dentre outros).

\subsection{Transformações históricas no espaço e na composição florística}

A questão da criação de animais e os relatos referentes ao histórico da família forneceram informações valiosas sobre as transformações que sofreu o espaço físico destinado ao plantio nos jardins-quintal bem como sua composição florística. A questão da alimentação e da subsistência foi outro tema importante que surgiu com freqüência nas entrevistas. 
Com relação à composição, a maioria dos informantes tinha na lembrança a presença abundante e predominante de árvores frutíferas e de plantas "duras" em geral, ou seja, etnovariedades que não eram facilmente prejudicadas pela criação que vivia solta nesta mesma área. Foi relatada também a presença de algumas "miudezas", como ervas medicinais e temperos, nos jardins-quintal dos antigos:

\begin{abstract}
"No terreiro era pra galinha e pé de laranja, laranja azeda, laranja aguada, lima (...) Todos os tipo de laranja tinha (...) Era banana, banana nanica, banana caturra que nóis falamo a naniquinha, banana caturra, maçã, banana pão nóis fala banana cinza. Banana da terra nóis fala banana maranhão. Tudo mundo tinha, difícil quem num tinha plantado (...) Tudo plantava, cafezal tudo mundo tinha" (Nazareno, 58, Pedro Cubas)

"(...) Da casa do meu pai era bem diferente, porque era bem grandão, tinha bastante espaço, bastante criação, pato, galinha... (...) tinha uns pé de goiaba, uns pé de limão, uns pé de mixirica" (Isabel, 35, Pedro Cubas).

"Era porque que nem a gente pranta muita flor e árvore agora. Antes era mais árvore grande que nem goiaba. Então era mais árvore grande, frutífera né (...) hoje em dia é mais ralo, mais pra flor (Eni, 40, Pedro Cubas).
\end{abstract}

Foi, ainda, estabelecida uma diferenciação entre o "terreiro" da "casa de fora" e o do "paiol", padrão este também encontrado por Pedroso-Júnior (2008). A "casa de fora" muitas vezes era considerada como a casa mais próxima à escola ou a algum ponto de aglomeração equivalente. O "paiol", por sua vez, foi definido como um barraco construído para estocagem dos produtos agrícolas da safra da lavoura, onde algumas famílias chegavam a passar a noite:

\begin{abstract}
"Eles ficavam mais na capuova do que em casa... Eles faziam um paiol na capuova lá e... Ficava na roça mais. Tinha vezes que passavam até 08 dias na roça. $E$ nóis ficava em casa porque nóis tinha que estudá então nóis ficava ali... E... Quando era de noite nóis ia dormi na casa de nossos tio, assim... E dia nóis vinha... Agora que ninguém mais trabalha na capuova aqui..." (Tina, 51, São Pedro)
\end{abstract}

$\mathrm{Na}$ "beira do terreiro" do paiol, foi relatado o plantio predominante de temperos e ervas medicinais:

"Porque no meu tempo né, eu com 8 anos eu lembro isso, o meu pai ele tinha paiol né, e ao redor ele plantava esses negócio de legume, né, mandioca. Aí depois, né, ele plantava o boldo, plantava o manjericão, esses tempero, e o boldo servia pra problema no estômago, né. Então sempre tinha um remedinho lá do lado." (Celina, 40, São Pedro)

"Eles faziam paiol mais era mais pra guardar o milho na roça, eles faziam o paiol, daí eles tiravam o milho, deixavam lá dentro, o arroz, ia carregando aos pouquinho pra cá (...) minha vó plantava assim uns pé de chuchu pra fazer... às vezes a gente resolviam fazer almoço lá 
também porque às vezes num tinha ninguém pra fazer almoço aqui pra levar, ele plantavam uns pé de chuchu, umas coisa assim..." (Noni, 33, Sapatu).

As flores não eram presença constante em nenhum dos dois locais, sendo que apenas as roseiras possuíam um papel estético significativo: "E no terreiro era tudo madeira, e plantação (...) tinha pouca flor, mais planta assim (...)" (Oneida, 67, Sapatu)

\begin{abstract}
"Eles não tinham esse costume de plantar flor. Os mais velhos não faziam conta disso, gente muito simples, né? Agora de uns tempos pra cá que ta achando bonito... Que trás alguma mudinha de planta e planta no terreiro..." (Cora, 67, São Pedro).

"Era laranja, café, palmeira que tinha. Bastante palmito, a gente cortava pra comer... Palmito. (...) Eles plantava rosa, plantava essas planta pra fazê chá quando a gente tava doente, tomava aquele chá sarava... Porque naquele tempo num tinha médico... (...) ० tamanho era que nem esse mesmo." (Ivi, 66, São Pedro)
\end{abstract}

A criação de animais, e sua diminuição em quantidade e variedade (como foi discutido na seção anterior) revelou um aspecto muito importante sobre a transformação do espaço entre as propriedades dos pequenos posseiros quilombolas em estudo. Em geral, o que se pôde compreender é que fatores como a proximidade a centros educacionais e médicos foram os primeiros elementos que impulsionaram a aproximação das UDs e a formação das vilas:

\begin{abstract}
"O pessoal morava aqui, né, todo mundo longe um do outro... hoje tá todo mundo aqui, por causa de melhoria de escola, de luz, de coisa, né? Porque antigamente morava longe porque não tinha nada disso, né não tinha médico, não tinha nada, tinha só a família. Não tinha luz... Era luz... Queria alumiá de noite era aquela urgência, não tinha nada de... Coisa que tem hoje" (Mora, 59, São Pedro).

"Antes a gente morava daqui lá umas horas andando. Aí nóis, tinha (...) que ir pra escola (...) então nos mudemo praqui pra modi punha as criança na escola, porque lá ficava muito difícil. E lá carecia a mulher ficar lá e eu ficava cá no mato sozinho, trabaiando (sic). Então, no tempo do prefeito Ari Mariano, então ele prometeu o material pra faze a escola, a gente tem burro ai, carrega no animal, carrega nas costas (...)" (Zico, 70, São Pedro)
\end{abstract}

Como uma das principais conseqüências desse processo muitos relataram (como discutido anteriormente) a simplificação e diminuição da criação de animais para corte, principalmente a de suínos: "Era diferente (...) agora a gente cultiva mais assim no terreiro né, mais um poquinho... Agora parece que é mais cultivado..." (Mirna, 60, Sapatu)

"Porque as coisa mudou muito porque agora, hoje, todo mundo mora na beira da estrada, como é que vai se cria porco. Aqui até galinha memo é difícil porque quando eu criava galinha, que logo que eu cheguei aqui, eu criava muita galinha, mas quantas vezes foi pegado galinha 
morta ali na estrada, que passava os cara de carro, e as galinha tavam no meio da estrada, passava por cima, matava. Então não dá por causa disso, porque a população evoluíram muito, e certo ponto e a regra também não permite que a gente crie criação porco por causa da contaminação na terra." (Cida, 64, Pedro Cubas).

"Pra cercar porque a criação, o porco, né, animal, passa pra cá... E hoje num tem mais isso, né? Já não cria porco. Devido à vigilância sanitária também que... Porco sai, às vezes faz cocô assim na rua, e é proibido por lei... A tendência tá diminuindo, cada dia que passa, nossos costumes, porque o que nós podia fazer aqui nós não pode fazer mais. A gente tá até prejudicando a saúde, da gente (...) Que a tendência é voltar a criar mais, pra bem longe daqui porque não pode fica solto na vila. A vontade ainda é criar, nós mesmos temo vontade de criar um pouco" (Mora, 54, São Pedro).

"Eu acho que diminui porque hoje em dia o povo tá mais assim saindo pra fora pra trabalhar. E os que fica às vezes num tem condições de tocá. De plantar, às vezes num tem uma área grande pra plantar... Tem pessoas aqui que a área de plantar é bom poquinho. E com essa estória de florestal, que se você derruba hoje tá pagando multa, o pessoal fica com medo de desmatar pra planta. E antigamente num tinha essas coisa né. Na época dos meus avós num tinha essas coisa." (Noni, 33, Sapatu)

"É o espaço, pequeno. E porco agora, por causa da vigilância sanitária tem que ter um lugar bem adequado. E antes não, a gente morava no sertão, fazia lá o chiqueiro, deixava lá, e hoje não. Hoje o meio ambiente ele cobra muito, e de primeiro meu pai ia fazer chiqueiro em água pequena, utilizava ali e escorria na água grande. E hoje não. Já não deixa e a gente sabe que tem pobrema. E também procura fazer a coisa normal, mais certo. Pra não prejudicar gente" (Eni, 40, São Pedro)

"(...) Pros negócio de criação, porque a criação ansim, os negócio de criação, de galinha, eles (...) ficavam perto da porta, e não plantavam nada perto da porta, essas coisa assim de planta" (Cris, 70, Pedro Cubas)

Por fim, uma mudança clara no habito alimentar e nos meios de subsistência pôde ser constatada através dos relatos de muitos informantes:

"A mistura era do mato, o arroz e o feijão era plantado do sitio, tinha muitas qualidade de feijão que hoje num tem, que eles plantavam, milho, faziam bastante farinha de milho, tinha o monjolo... O meu tio tinha monjolo e o milho no monjolo pra socar depois ponhava água oito dias, no cesto, e depois que tirava o milho ali do cesto lavava bem lavado, o lodo, depois escorria e punha no sol, daí fazia a farinha... Daí a gente fazia farinha de rosca, e saco de farinha, vendia... Farinha de mandioca também tinha roda... A gente relava, fazia farinha torrada, porque num dependia de comprar. A rapadura, o café, era tomado do café de rapadura, que eles tinham moenda, plantava aquele canaviar, faziam rapadura no... o trato de tomar rapadura, ninguém tomava açúcar, ninguém conhecia açúcar, ninguém conhecia o que era farinha de milho comprado, farinha de mandioca comprado, e café também era cafezal, os pai da gente plantava aqueles cafezalzão (...)" (Cora, 67, São Pedro)

"Eu fui criado com muita carne de bicho (...) Eu fui criado com isso, então, carne forte, muito sadia, e não usava produto químico, a gente usava só as coisa orgânico... (...) a alimentação não compara como hoje, você começa com o leite de vaca. Antigamente você num tinha vacina pra boi, num tinha vacina pra nada (...) Eu num vô em médico, difícil..." (Roberto, 78, Pedro Cubas).

De maneira geral, a tendência que se observou é a do aumento do consumo de produtos industrializados em detrimento dos alimentos vindos diretamente da 
lavoura, e uma dependência cada vez maior da compra de produtos para a obtenção de certos itens em detrimento dos antigos sistemas sociais de distribuição de recursos (como festas, mutirões, feriados religiosos):

"O pessoal gostava muito do mutirão de colheita de arroz. Tinha, todo mundo tinha. Hoje, num... Um ou dois tem, um ano tem, outro ano não tem... Acha mais fácil tirar palmito. Tira palmito, porque... E comprar lá pronto lá na cidade... É assim que acontece! Hoje nós temo o que, uma máquina de pilar arroz aí que... Esse ano nós não temo arroz suficiente pra pilar nela, né? Ninguém quase plantou, quem plantou, plantou pouco também porque é difícil..." (Mora, 54, São Pedro).

"Que antigamente ninguém comprava gordura, todo mundo tinha sempre um porco pra matá, de vez em quando matava um porco. Ninguém vendia, difícil vender. Trocava.. Vamo supor, hoje eu tenho um capado, aí emprestava pedaço pra outro. Era assim. Num era só eu que matava, o outro matava, então dava pra um também. Em dia de mutirão matava um, dois, a turmada comia carne pra caramba aqui. Tinha nego que se borrava até de comer carne (...)" (Nazareno, 58, Pedro Cubas).

\title{
Essa mudança foi muitas vezes diretamente relacionada pelos informantes
}

como uma conseqüência direta da diminuição do interesse em se criar porcos, e da

dificuldade em se abrir novas áreas de roça para o plantio e cultivo:

\begin{abstract}
"Acho que as pessoa num se esforçam. E de primeiro eles se criavam ali, eles se esforçavam de trabalhar, eles roçava (...). Agora hoje em dia eles são mais (...) eles tentam menos. Porque se eles planta uma banana eles vende e vão compra no mercado. E de primeiro a gente se criava ali do serviço de força da gente mesmo." (Ivi, 66, São Pedro).
\end{abstract}

“(...) Dispois que entrou esse negócio de fazenda, esse negocio de corte de palmito, e aí as pessoa já num comiam mais as coisa puro. Que nem nóis comia antigamente, galinha, mais as coisas (...) Pra cá era pó de café, era açúcar, era óleo, que esse óleo a gente num usava, a gente usava banha de porco, era arroz pilado, era tudo isso, que tudo isso nóis comia natural. Um arroz pilado no pilão, era o feijão. O feijão que sempre comprava a mais porque aqui nossa terra não é muito produtivo pra feijão, a gente planta mas não é muito produtivo. Mas 0 café a gente bebia, café da garapa da cana, a gente (...) Usava o café só torrado em casa. Que se a gente num tinha aqui, mas minha mãe mesmo era uma que ia lá pro Batatal colher café de algum que dava café pra colher numa meia, e a gente num comprava, o ano inteiro a gente num comprava café. A gente aproveitava arroz pilado no pilão, as folha que a gente comia, num comia essas farinha de mandioca que naquele tempo nem existia essas farinha de mandioca que vem hoje que nem é farinha de mandioca, é raspagem de banana, pra falar verdade, a gente comia a farinha feita da gente, do sitio mesmo" (Cida, 64, Pedro Cubas).

"Comia só coisa natural daqui, agora não, agora é tudo trazido de fora... Teve uma época que... Acho que em 60, 64 por aí. As pessoas foram saindo daqui porque, devido... Por não poder roçar, derrubar num lugar assim que já e acostumado, né? Daí desanimaram e foram saindo, o que foi que aconteceu? Ai as pessoa que fica né, é... Faz um pouquinho mas não pode fazer muito do que eles faziam, então. Acaba dificultando tem que comprar lá pra cidade, né? (...) Eles podiam plantar onde quisessem, antigamente era assim. Achava que aquele terreno é bom pra arroz, ali eles roçavam, plantavam e dava! Achava que aquele terreno era bom pra plantar milho, ali eles roçava, plantava e dava! E hoje não, às vezes é escolhido pelo sistema que tem hoje, de não poder... Então dificultou muito também essa parte (...) dificultou muito! Porque beira de água, que aonde dá uma planta às vezes boa, porque é uma época que às vezes não chove, então uma planta tando lá na beira da água com aquele vapor da água também ajuda a planta a crescer, então agora não pode mais isso. A roça também era 
enorme. Plantava até alqueire de milho, arroz, e era aquela roçona grande..." (Mora, 59, São Pedro).

Em suma, tornou-se evidente que a aproximação das casas (e a conseqüente formação de vilarejos), a mudança dos hábitos alimentares, a imposição por lei de áreas protegidas no território de ocupação das comunidades, e o desinteresse crescente dos mais jovens em se envolverem com atividades agrícolas, são elementos chave na transformação do espaço e composição florística dos jardinsquintal das comunidades quilombolas estudadas (desde o tempo "dos antigos" até os tempos atuais).

\subsection{A relação entre as variedades de roça e as dos jardins- quintal}

Algumas etnovariedades cultivadas no espaço dos jardins-quintal são também cultivadas em áreas de roça per se de maneira simultânea. No entanto, a figura 4.28 mostra que, de maneira geral, apenas 9,82\% $(n=278)$ de todas as etnovariedades encontradas nos 71 jardins-quintal estudados são também cultivadas em áreas de roça, demonstrando a pouca sobreposição de função entre estas subunidades agrícolas.

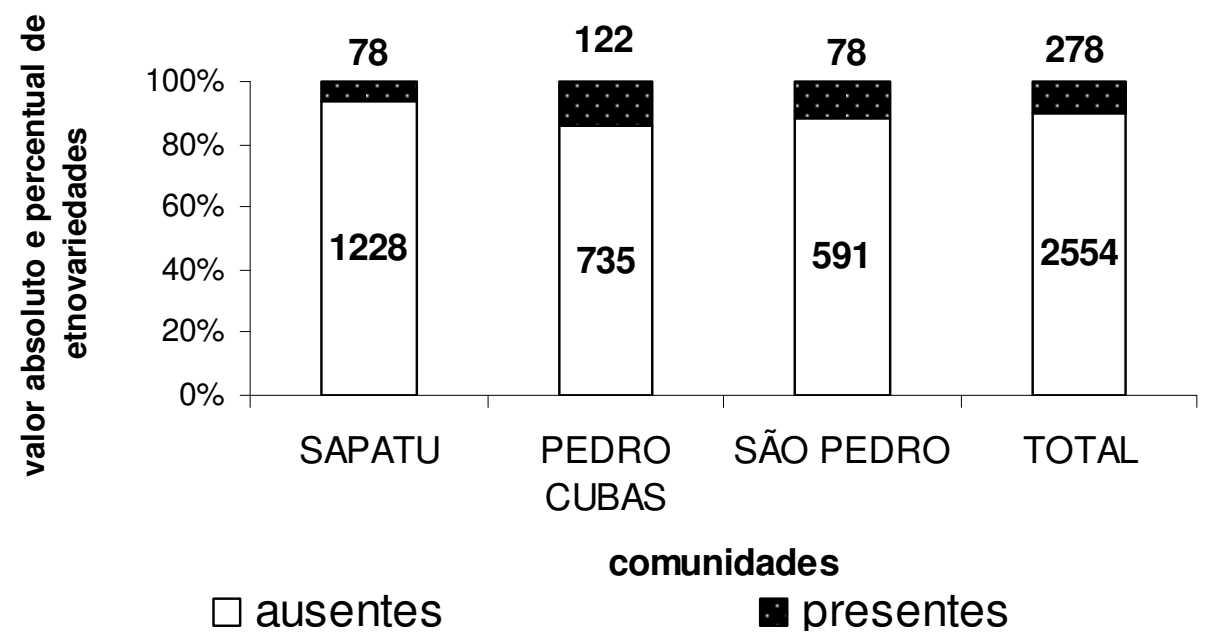

Figura 4.28: contagem de etnovariedades cultivadas nos espaços dos jardins-quintal e que estavam presentes ou ausentes no espaço destinado ao cultivo de roça, nas comunidades quilombolas de Sapatu, São Pedro e Pedro Cubas 
As etnovariedades que são mais comumente cultivadas nos jardins-quintal e nas roças simultaneamente são a banana (Musa sp.), a mandioca (Manihot esculenta Crantz), a cana (Saccharum officinarum L), o taiá (Xanthosoma cf blandum Schott), e o cará (Dioscorea sp.). Além destas, a goiaba (Psidium guajava L.), o mamão (Carica sp.), o palmito Jussara (Euterpe edulis Mart), a laranja mexerica (Citrus reticulata Blanco), o limão vermelho (Citrus limonia (L.) Osbeck), a jaboticaba (Myrciaria cauliflora (Mart) O. Berg), a jaca (Artocapus heterophyllus Lam.) e a castanheira (Pachira cf aquatica Aubl.) são também freqüentemente encontradas nas áreas roças. No caso desta segunda listagem, é muito comum que essas etnovariedades tenham permanecido nas áreas de roçado como cultivares remanescentes de antigos moradores. Ou, ainda, tenho nascido espontaneamente de sementes jogadas no local. Nos dois casos, os informantes comentaram o interesse em encorajar o crescimento e a manutenção dessas plantas, já que as mesmas podem complementar a alimentação daqueles que trabalham nesses espaços.

Foi realizado o teste de Kruskal-Wallis para detectar diferenças significativas entre as medianas das contagens realizadas para cada comunidade com relação às etnovariedades presentes e ausentes simultaneamente nas áreas de roça e nos espaços dos jardins-quintal (Tabela 4.8). Existe uma diferença significativa entre as comunidades com relação as etnovariedades consideradas "ausentes" dos espaços dos jardins-quintal $(H=8,48 ; G L=2 ; p=0,014)$. Pedro Cubas e São Pedro se mostram como as mais diferentes entre si com relação a esse aspecto (Tabela 4.8). 
Tabela 4.7: teste não paramétrico de comparação de medianas (Kruskal-Wallis) das contagens relativas às etnovariedades cultivadas simultaneamente no espaço nos jardins-quintal e nas roças. O símbolo * indica diferença significativa, ao nível de significância de $5 \%$.

COMUNIDADES

categorias de uso Kruskal-Wallis Sapatu Pedro Cubas São Pedro

\begin{tabular}{|c|c|c|c|c|}
\hline & & $n=30$ & $\mathrm{n}=27$ & $\mathrm{n}=14$ \\
\hline \multirow{6}{*}{ ausentes } & mediana & 39 & 24 & 42,5 \\
\hline & rank médio & 39,5 & 26,5 & 43,6 \\
\hline & $\mathbf{Z}$ & 1,43 & $-2,84$ & 1,67 \\
\hline & $\mathbf{H}$ & \multicolumn{3}{|c|}{8,48} \\
\hline & DF & \multicolumn{3}{|c|}{2} \\
\hline & $\mathbf{p}$ & \multicolumn{3}{|c|}{$0,014^{*}$} \\
\hline \multirow{6}{*}{ presentes } & mediana & 2 & 0 & 4 \\
\hline & rank médio & 34,7 & 32,7 & 42,4 \\
\hline & $\mathbf{Z}$ & $-0,27$ & $-0,9$ & 1,42 \\
\hline & $\mathbf{H}$ & \multicolumn{3}{|c|}{2,29} \\
\hline & DF & \multicolumn{3}{|c|}{2} \\
\hline & p & \multicolumn{3}{|c|}{0,319} \\
\hline
\end{tabular}

\subsection{Transformações sócio-econômicas e os jardins-quintal}

A relação entre as diferenças socioeconômicas das unidades domésticas quilombolas é mostrada nos dendogramas de distância das Figuras 4.29 e 4.30. Algumas UDs foram incorporadas em uma única observação (G1, G2, G3...) pelo critério de possuírem o mesmo número de eletrodomésticos, nível de escolaridade do chefe de família e liderança. A primeira e segunda colunas da Tabela 4.9 mostram a correspondência entre os grupos nomeados no dendograma e o código atribuído às unidades domésticas. Cada UD, por sua vez, tem definido um índice para si, especificado de acordo com os critérios número de eletrodoméstico e nível de escolaridade do chefe de família.

O primeiro dendograma (Figura 429) foi definido utilizando-se como variáveis apenas o número de eletrodomésticos por UD e nível de escolaridade do chefe de 
família. Observam-se, nesse caso, pelo menos 5 grupos bem delimitados. A tabela original dos grupos - dispostos na mesma ordem em que aparecem no dendograma (Tabela 4.9) - revela a similaridade entre as unidades domésticas. As UDs do primeiro grupo (PEC9, SAP9, SP12, SAP12, SP5) possuem entre 4 e 7 eletrodomésticos e nível de escolaridade do chefe de família que varia de médio incompleto a médio completo. As UDs do segundo (e menor) grupo (PEC19, PEC27, SP3, SP14) apresentam uma queda no número de eletrodomésticos (entre 1 e 2), mas o nível de escolaridade do chefe de família ainda é alto, variando entre médio incompleto a superior incompleto. $O$ terceiro grupo (SAP19, SAP24, SP7, SAP20, SAP7, SAP1, SP10, SAP25, SP12, SAP20, SAP7) possui UDs com alto número de eletrodomésticos (entre 6 e 8), porém o nível de escolaridade do chefe de família decai e fica entre o analfabetismo e o fundamental incompleto. No quarto (e maior) grupo (SAP14, SAP30, SAP21, SAP22, SAP10, SAP13, SP13, PEC10, PEC11, PEC20, SAP5, SAP15, PEC23, SAP18, SP9, SAP26, PEC4, SAP2, SP1, SP4, SP8, PEC2, PEC6, PEC12, SAP6, SAP23, SAP28, SP6, SP11, PEC14, SAP8, SAP11, PEC1, PEC16, PEC18, SAP3, SAP17, SAP29) o número de eletrodomésticos passa a variar entre 2 e 5 , e o nível de escolaridade se mantém. No quinto e último grupo (PEC3, PEC5, PEC7, PEC17, PEC8, PEC13, PEC21, PEC25, PEC26, PEC15, PEC22, PEC24, SAP4, SAP16, SAP27, SP2) o número de eletrodomésticos decai e passa a variar entre 0 e 1, mas o nível de escolaridade ainda se mantém. 


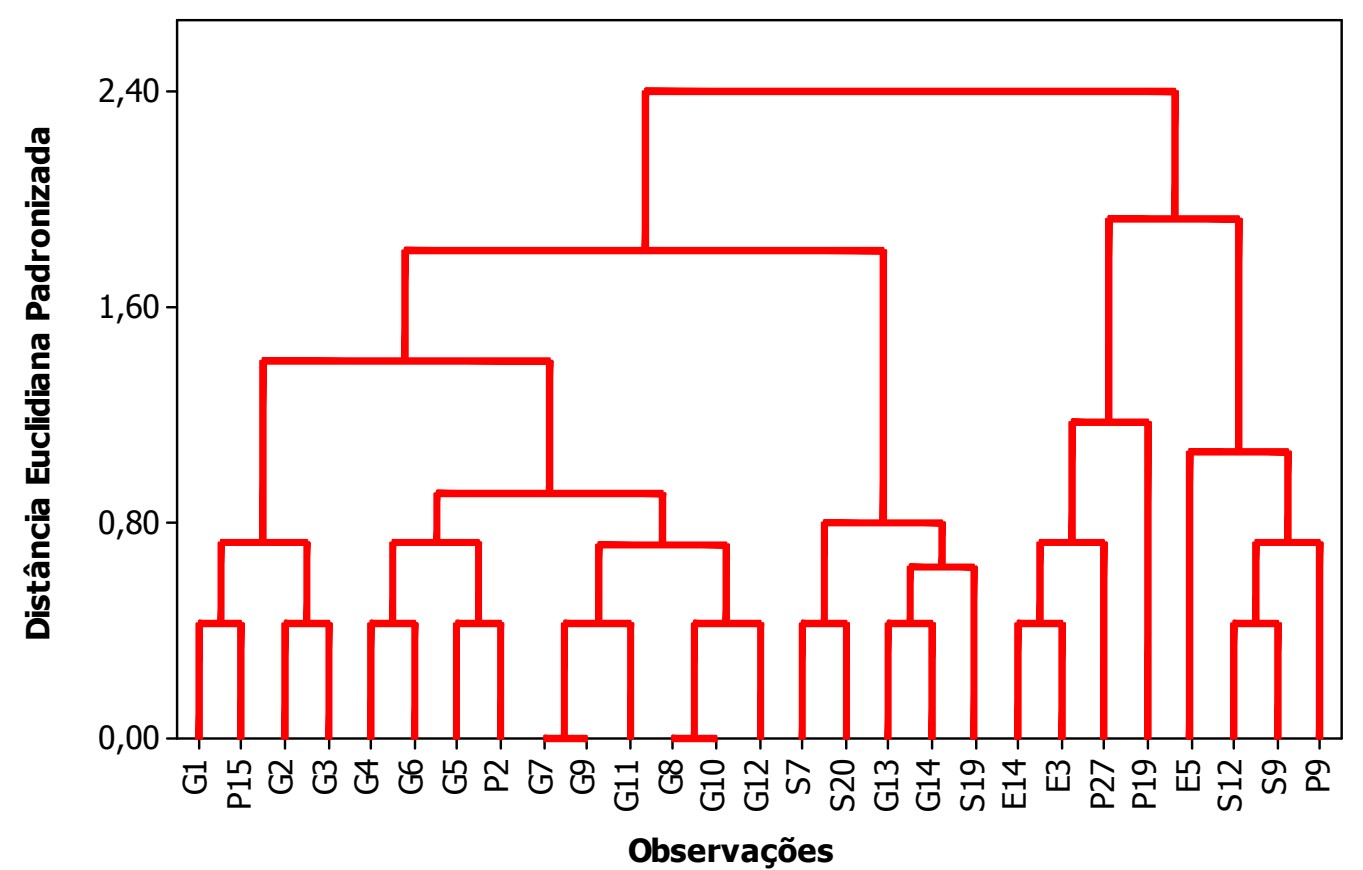

Figura 4.29: dendograma baseado no número de eletrodomésticos e nível de escolaridade do chefe de família $(n=71)$, estruturado pelo método de análise de agrupamento hierárquico. Algoritmo de agrupamento: Distância Euclidiana Padronizada. Método de aglomeração: média aritmética não ponderada (UPGMA), sem incluir o fator liderança

Tabela 4.9: índices equivalentes ao número de eletrodomésticos e nível de escolaridade por unidade doméstica. As unidades domésticas estão ordenadas na tabela de acordo com a classificação (Figura 4.29), e os grupos definidos pelo dendograma estão separados pelos sombreamentos ( ${ }^{*}$ eletrodomésticos: variação de 0 (índice 0) a 8 (índice 1); ${ }^{* *}$ escolaridade: analfabeto (índice 0), fundamental incompleto (índice 0,2), fundamental completo (índice 0,4), médio incompleto (índice 0,6 ), médio completo (índice 0,8 ) a superior incompleto (índice 1)), sem incluir o fator liderança (continua).

Observações

(dendograma) código da UD eletrodomésticos* escolaridade ${ }^{\star *}$

\begin{tabular}{cccc}
\hline P9 & PEC9 & 0,75 & 0,8 \\
S9 & SAP9 & 0,875 & 0,6 \\
S12 & SAP12 & 0,75 & 0,6 \\
E5 & SP5 & 0,5 & 0,6 \\
P19 & PEC19 & 0,125 & 1 \\
P27 & PEC27 & 0,25 & 0,8 \\
E3 & SP3 & 0,25 & 0,6 \\
E14 & SP14 & 0,125 & 0,6 \\
\hline
\end{tabular}


Continuação da Tabela 4.8: índices equivalentes ao número de eletrodomésticos e nível de escolaridade por unidade doméstica. As unidades domésticas estão ordenadas na tabela de acordo com a classificação (Figura 4.29), e os grupos definidos pelo dendograma estão separados pelos sombreamentos ( ${ }^{*}$ eletrodomésticos: variação de 0 (índice 0) a 8 (índice 1); **escolaridade: analfabeto (índice 0), fundamental incompleto (índice 0,2), fundamental completo (índice 0,4), médio incompleto (índice 0,6), médio completo (índice 0,8) a superior incompleto (índice 1)), sem incluir o fator liderança (continua).

\section{Observações}

\begin{tabular}{|c|c|c|c|}
\hline (dendograma) & código (UD) & eletrodomésticos* & escolaridade $^{\star \star}$ \\
\hline S19 & SAP19 & 1 & 0,2 \\
\hline G14 & SAP24 & 0,875 & 0,2 \\
\hline G14 & SP7 & 0,875 & 0,2 \\
\hline G13 & SAP1 & 0,75 & 0,2 \\
\hline G13 & SP10 & 0,75 & 0,2 \\
\hline G13 & SAP25 & 0,75 & 0,2 \\
\hline G13 & SP12 & 0,75 & 0,2 \\
\hline $\mathrm{S} 20$ & SAP20 & 0,875 & 0 \\
\hline S7 & SAP7 & 0,75 & 0 \\
\hline G12 & SAP14 & 0,625 & 0,2 \\
\hline G12 & SAP30 & 0,625 & 0,2 \\
\hline G12 & SAP21 & 0,675 & 0,2 \\
\hline G10 & SAP10 & 0,5 & 0,2 \\
\hline G10 & SAP13 & 0,5 & 0,2 \\
\hline G10 & SP13 & 0,5 & 0,2 \\
\hline G8 & PEC11 & 0,5 & 0,2 \\
\hline G8 & PEC20 & 0,5 & 0,2 \\
\hline G8 & SAP5 & 0,5 & 0,2 \\
\hline G8 & SAP15 & 0,5 & 0,2 \\
\hline G11 & SAP18 & 0,625 & 0 \\
\hline G11 & SP9 & 0,625 & 0 \\
\hline G9 & SAP26 & 0,5 & 0 \\
\hline G9 & PEC4 & 0,5 & 0 \\
\hline G7 & SAP2 & 0,5 & 0 \\
\hline G7 & SP1 & 0,5 & 0 \\
\hline
\end{tabular}


Continuação da Tabela 4.8: índices equivalentes ao número de eletrodomésticos e nível de escolaridade por unidade doméstica. As unidades domésticas estão ordenadas na tabela de acordo com a classificação (Figura 4.29), e os grupos definidos pelo dendograma estão separados pelos sombreamentos ( ${ }^{*}$ eletrodomésticos: variação de 0 (índice 0) a 8 (índice 1); **escolaridade: analfabeto (índice 0), fundamental incompleto (índice 0,2), fundamental completo (índice 0,4), médio incompleto (índice 0,6), médio completo (índice 0,8) a superior incompleto (índice 1)), sem incluir o fator liderança (continua).

\section{Observações}

\begin{tabular}{|c|c|c|c|}
\hline (dendograma) & código (UD) & eletrodomésticos* & escolaridade ${ }^{\star \star}$ \\
\hline G7 & SP4 & 0,5 & 0 \\
\hline G7 & SP8 & 0,5 & 0 \\
\hline P2 & PEC2 & 0,375 & 0,2 \\
\hline G5 & PEC6 & 0,25 & 0,2 \\
\hline G5 & PEC12 & 0,25 & 0,2 \\
\hline G5 & SAP6 & 0,25 & 0,2 \\
\hline G5 & SAP23 & 0,25 & 0,2 \\
\hline G5 & SAP28 & 0,25 & 0,2 \\
\hline G5 & SP6 & 0,25 & 0,2 \\
\hline G5 & SP11 & 0,25 & 0,2 \\
\hline G6 & PEC14 & 0,375 & 0 \\
\hline G6 & SAP8 & 0,375 & 0 \\
\hline G6 & SAP11 & 0,375 & 0 \\
\hline G4 & PEC1 & 0,25 & 0 \\
\hline G4 & PEC16 & 0,25 & 0 \\
\hline G4 & PEC18 & 0,25 & 0 \\
\hline G4 & SAP3 & 0,25 & 0 \\
\hline G4 & SAP17 & 0,25 & 0 \\
\hline G4 & SAP29 & 0,25 & 0 \\
\hline G3 & PEC3 & 0,125 & 0,2 \\
\hline G3 & PEC5 & 0,125 & 0,2 \\
\hline G3 & PEC7 & 0,125 & 0,2 \\
\hline G3 & PEC17 & 0,125 & 0,2 \\
\hline G2 & PEC8 & 0 & 0,2 \\
\hline G2 & PEC13 & 0 & 0,2 \\
\hline G2 & PEC21 & 0 & 0,2 \\
\hline
\end{tabular}


Conclusão da Tabela 4.8: índices equivalentes ao número de eletrodomésticos e nível de escolaridade por unidade doméstica. As unidades domésticas estão ordenadas na tabela de acordo com a classificação (Figura 4.29), e os grupos definidos pelo dendograma estão separados pelos sombreamentos ( ${ }^{*}$ eletrodomésticos: variação de 0 (índice 0) a 8 (índice 1); **escolaridade: analfabeto (índice 0), fundamental incompleto (índice 0,2), fundamental completo (índice 0,4), médio incompleto (índice 0,6), médio completo (índice 0,8 ) a superior incompleto (índice 1)), sem incluir o fator liderança.

Observações

\begin{tabular}{cccc} 
(dendograma) & código (UD) & eletrodomésticos $^{*}$ & escolaridade $^{\star *}$ \\
\hline G2 & PEC25 & 0 & 0,2 \\
G2 & PEC26 & 0 & 0,2 \\
P15 & PEC15 & 0,125 & 0 \\
G1 & PEC22 & 0 & 0 \\
G1 & PEC24 & 0 & 0 \\
G1 & SAP4 & 0 & 0 \\
G1 & SAP16 & 0 & 0 \\
G1 & SAP27 & 0 & 0 \\
G1 & SP2 & 0 & 0
\end{tabular}

O segundo dendograma (Figura 4.30) foi determinado utilizando-se como variáveis o número de eletrodomésticos por UD, o nível de escolaridade do chefe de família e o fator liderança (participação significativa ou não nas tomadas de decisão da comunidade do chefe de família). A tabela original dos grupos - dispostos na mesma ordem em que aparecem no dendograma (Tabela 4.10) - revela a similaridade entre as unidades domésticas. É possível observar, também para esse caso, pelo menos 5 grupos bem delimitados. O primeiro grupo (SAP10, SAP13, SP13, SAP26, PEC4) é formado por "líderes comunitários" com quatro eletrodomésticos e nível de escolaridade que varia entre 0 analfabetismo e o fundamental incompleto. O segundo grupo (PEC9, PEC19, SP14) é formado por UDs com chefes de famílias "líderes" número de eletrodomésticos variando de 1 a 6 , e nível de escolaridade do chefe de família alto, variando entre superior incompleto e médio incompleto. O terceiro grupo (SP5, PEC27, SP3) inicia a leva de UDs que não dispõem de "líderes comunitários" na família, mas tem um nível de escolaridade alto dentre os chefes de família (médio incompleto, médio completo), e um número de eletrodomésticos que varia entre 2 e 4 . O quarto grupo (SAP9, SAP12, SAP19, SAP24, SP7, SAP1, SP10, SAP25, SP12, SAP20, SAP7) conta com UDs que 
possuem entre 6 e 8 eletrodomésticos e nível de escolaridade altamente variável (do analfabetismo ao médio incompleto). O quinto, último e maior grupo (SAP14, SAP30, SAP21, SAP22, PEC10, PEC11, PEC20, SAP5, SAP15, PEC23, SAP18, SP9, SAP2, SP1, SP4, SP8, PEC2, PEC6, PEC12, SAP6, SAP23, SAP28, SP6, SP11, PEC14, SAP8, SAP11, PEC1, PEC16, PEC18, SAP3, SAP17, SAP29, PEC3, PEC5, PEC7, PEC17, PEC8, PEC13, PEC21, PEC25, PEC26, PEC15, PEC22, PEC24, SAP4, SAP16, SAP27, SP2) é composto por UDs com alta variação de eletrodomésticos (de 0 a 5) e baixo nível de escolaridade dentre os chefes de família (variação entre analfabetismo e fundamental incompleto).

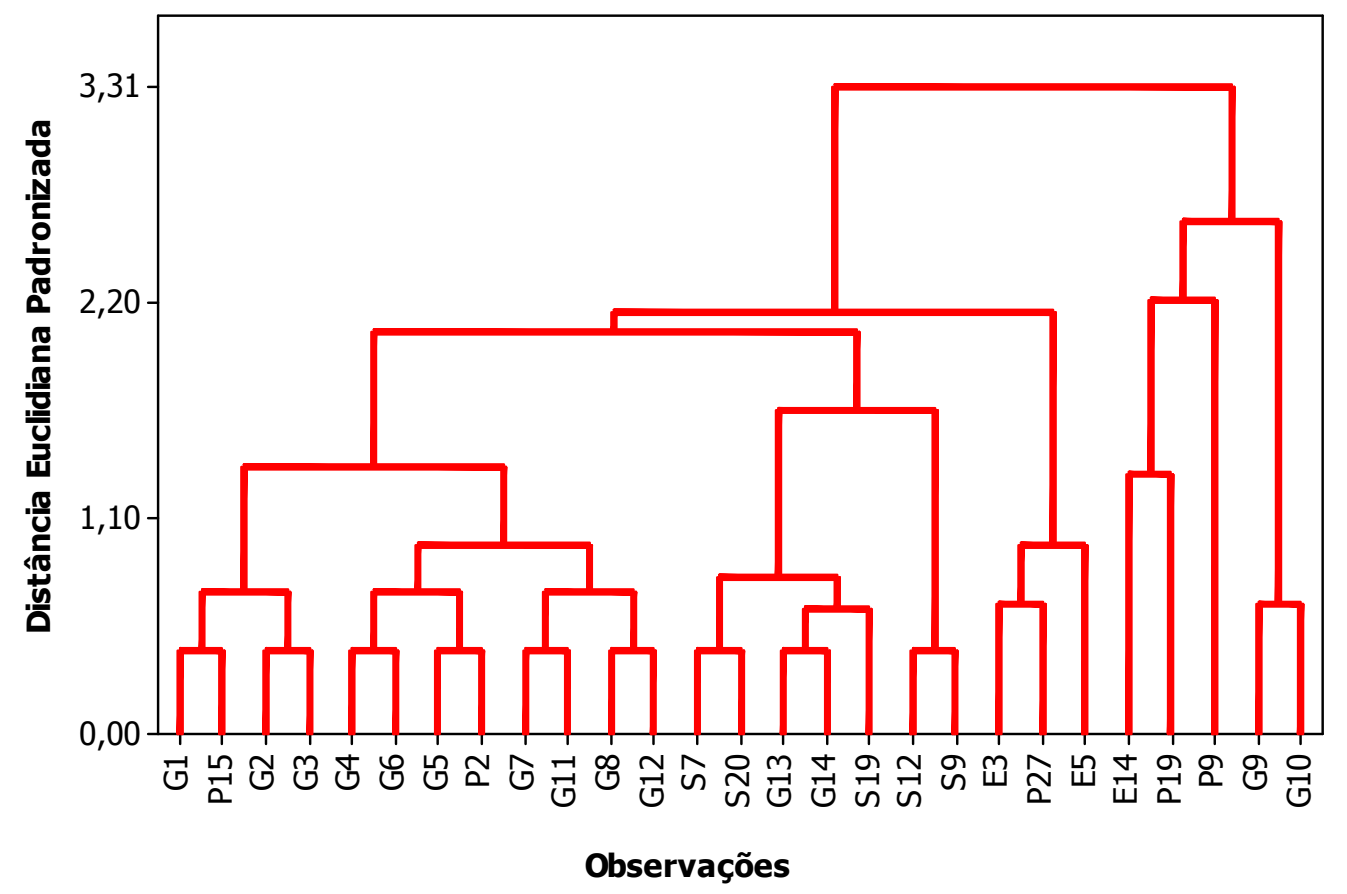

Figura 4.30: dendograma baseado no número de eletrodomésticos e nível de escolaridade do chefe de família $(n=71)$, estruturado pelo método de análise de agrupamento hierárquico. Algoritmo de agrupamento: Distância Euclidiana Padronizada. Método de aglomeração: média aritmética não ponderada (UPGMA), incluindo o fator liderança. 
Tabela 4.9: índices equivalentes ao número de eletrodomésticos, nível de escolaridade e liderança por unidade doméstica. As unidades domésticas estão ordenadas na tabela de acordo com a classificação da Figura 4.30, e os grupos definidos pelo dendograma estão separados pelos sombreamentos ("eletrodomésticos: variação de 0 (índice 0 ) a 8 (índice 1); **escolaridade: analfabeto (índice 0), fundamental incompleto (índice 0,2), fundamental completo (índice 0,4), médio incompleto (índice 0,6), médio completo (índice $0,8)$ a superior incompleto (índice 1$)^{* * *}$;iderança: presença e ausência) (continua).

\begin{tabular}{|c|c|c|c|c|}
\hline $\begin{array}{l}\text { observações } \\
\text { (dendograma) }\end{array}$ & $\begin{array}{l}\text { código } \\
\text { (UD) }\end{array}$ & eletrodomésticos* & escolaridade ${ }^{\star \star}$ & liderança*** \\
\hline G10 & SAP10 & 0,5 & 0,2 & 1 \\
\hline G10 & SAP13 & 0,5 & 0,2 & 1 \\
\hline G10 & SP13 & 0,5 & 0,2 & 1 \\
\hline G9 & SAP26 & 0,5 & 0 & 1 \\
\hline G9 & PEC4 & 0,5 & 0 & 1 \\
\hline P9 & PEC9 & 0,75 & 0,8 & 1 \\
\hline P19 & PEC19 & 0,125 & 1 & 1 \\
\hline E14 & SP14 & 0,125 & 0,6 & 1 \\
\hline E5 & SP5 & 0,5 & 0,6 & 0 \\
\hline P27 & PEC27 & 0,25 & 0,8 & 0 \\
\hline E3 & SP3 & 0,25 & 0,6 & 0 \\
\hline S9 & SAP9 & 0,875 & 0,6 & 0 \\
\hline S12 & SAP12 & 0,75 & 0,6 & 0 \\
\hline $\mathrm{S} 19$ & SAP19 & 1 & 0,2 & 0 \\
\hline G14 & SAP24 & 0,875 & 0,2 & 0 \\
\hline G14 & SP7 & 0,875 & 0,2 & 0 \\
\hline G13 & SAP1 & 0,75 & 0,2 & 0 \\
\hline G13 & SP10 & 0,75 & 0,2 & 0 \\
\hline G13 & SAP25 & 0,75 & 0,2 & 0 \\
\hline G13 & SP12 & 0,75 & 0,2 & 0 \\
\hline $\mathrm{S} 20$ & SAP20 & 0,875 & 0 & 0 \\
\hline S7 & SAP7 & 0,75 & 0 & 0 \\
\hline G12 & SAP30 & 0,625 & 0,2 & 0 \\
\hline G12 & SAP21 & 0,675 & 0,2 & 0 \\
\hline G12 & SAP22 & 0,675 & 0,2 & 0 \\
\hline G8 & PEC10 & 0,5 & 0,2 & 0 \\
\hline
\end{tabular}


Continuação da Tabela 4.10: índices equivalentes ao número de eletrodomésticos, nível de escolaridade e liderança por unidade doméstica. As unidades domésticas estão ordenadas na tabela de acordo com a classificação da Figura 4.30, e os grupos definidos pelo dendograma estão separados pelos sombreamentos ( ${ }^{*}$ eletrodomésticos: variação de 0 (índice 0) a 8 (índice 1); **escolaridade: analfabeto (índice 0), fundamental incompleto (índice 0,2), fundamental completo (índice 0,4), médio incompleto (índice 0,6), médio completo (índice 0,8) a superior incompleto (índice $1)^{; * *}$ liderança: presença e ausência) (continua).

\begin{tabular}{|c|c|c|c|c|}
\hline $\begin{array}{l}\text { observações } \\
\text { (dendograma) }\end{array}$ & $\begin{array}{l}\text { código } \\
\text { (UD) }\end{array}$ & eletrodomésticos* & escolaridade $^{\star \star}$ & liderança*** \\
\hline G8 & PEC11 & 0,5 & 0,2 & 0 \\
\hline G8 & PEC20 & 0,5 & 0,2 & 0 \\
\hline G8 & SAP5 & 0,5 & 0,2 & 0 \\
\hline G8 & SAP15 & 0,5 & 0,2 & 0 \\
\hline G11 & PEC23 & 0,625 & 0 & 0 \\
\hline G11 & SAP18 & 0,625 & 0 & 0 \\
\hline G11 & SP9 & 0,625 & 0 & 0 \\
\hline G7 & SAP2 & 0,5 & 0 & 0 \\
\hline G7 & SP1 & 0,5 & 0 & 0 \\
\hline G7 & SP4 & 0,5 & 0 & 0 \\
\hline G7 & SP8 & 0,5 & 0 & 0 \\
\hline P2 & PEC2 & 0,375 & 0,2 & 0 \\
\hline G5 & PEC6 & 0,25 & 0,2 & 0 \\
\hline G5 & PEC12 & 0,25 & 0,2 & 0 \\
\hline G5 & SAP6 & 0,25 & 0,2 & 0 \\
\hline G5 & SAP23 & 0,25 & 0,2 & 0 \\
\hline G5 & SAP28 & 0,25 & 0,2 & 0 \\
\hline G12 & SAP30 & 0,625 & 0,2 & 0 \\
\hline G12 & SAP30 & 0,625 & 0,2 & 0 \\
\hline G6 & SAP8 & 0,375 & 0 & 0 \\
\hline G6 & SAP11 & 0,375 & 0 & 0 \\
\hline G4 & PEC1 & 0,25 & 0 & 0 \\
\hline G4 & PEC16 & 0,25 & 0 & 0 \\
\hline
\end{tabular}


Continuação da Tabela 4.10: índices equivalentes ao número de eletrodomésticos, nível de escolaridade e liderança por unidade doméstica. As unidades domésticas estão ordenadas na tabela de acordo com a classificação (Figura 4.30), e os grupos definidos pelo dendograma estão separados pelos sombreamentos ( ${ }^{*}$ eletrodomésticos: variação de 0 (índice 0) a 8 (índice 1); ${ }^{\star *}$ escolaridade: analfabeto (índice 0), fundamental incompleto (índice 0,2), fundamental completo (índice 0,4), médio incompleto (índice 0,6 ), médio completo (índice 0,8) a superior incompleto (índice 1); ;**liderança: presença e ausência) (continua).

\begin{tabular}{|c|c|c|c|c|}
\hline $\begin{array}{l}\text { observações } \\
\text { (dendograma) }\end{array}$ & $\begin{array}{l}\text { código } \\
\text { (UD) }\end{array}$ & eletrodomésticos* & escolaridade ${ }^{* *}$ & liderança*** \\
\hline G4 & PEC18 & 0,25 & 0 & 0 \\
\hline G4 & SAP3 & 0,25 & 0 & 0 \\
\hline G4 & SAP17 & 0,25 & 0 & 0 \\
\hline G4 & SAP29 & 0,25 & 0 & 0 \\
\hline G3 & PEC3 & 0,125 & 0,2 & 0 \\
\hline G3 & PEC5 & 0,125 & 0,2 & 0 \\
\hline G3 & PEC7 & 0,125 & 0,2 & 0 \\
\hline G3 & PEC17 & 0,125 & 0,2 & 0 \\
\hline G2 & PEC8 & 0 & 0,2 & 0 \\
\hline G2 & PEC13 & 0 & 0,2 & 0 \\
\hline G2 & PEC21 & 0 & 0,2 & 0 \\
\hline G2 & PEC25 & 0 & 0,2 & 0 \\
\hline G2 & PEC26 & 0 & 0,2 & 0 \\
\hline P15 & PEC15 & 0,125 & 0 & 0 \\
\hline G1 & PEC22 & 0 & 0 & 0 \\
\hline G1 & PEC24 & 0 & 0 & 0 \\
\hline G1 & SAP4 & 0 & 0 & 0 \\
\hline G1 & SAP16 & 0 & 0 & 0 \\
\hline G1 & SAP27 & 0 & 0 & 0 \\
\hline G1 & SP2 & 0 & 0 & 0 \\
\hline
\end{tabular}

Ambas as classificações fornecidas pelos métodos de agrupamento descritos anteriormente foram relacionadas à diversidade de etnovariedades por unidade de jardim-quintal, resultando nos gráficos de dispersão das Figuras 4.31 e 4.32 . O gráfico de dispersão da Figura 4.31 utiliza a classificação socioeconômica das UDs realizada sem considerar o fator "liderança" (Tabela 9). No gráfico da Figura 4.31, o fator "liderança" foi incluído (Tabela 10). Como se observa, nenhuma dessas 
relações apresentou um padrão claro de comportamento. Houve um grande espalhamento dos pontos, indicando não haver uma tendência a uma relação entre status socioeconômico e a diversidade de etnovariedades cultivadas no espaço de jardim-quintal. Mesmo que seja feita um regressão destes dados a incerteza na estimativa a partir da equação da reta é muito grande.

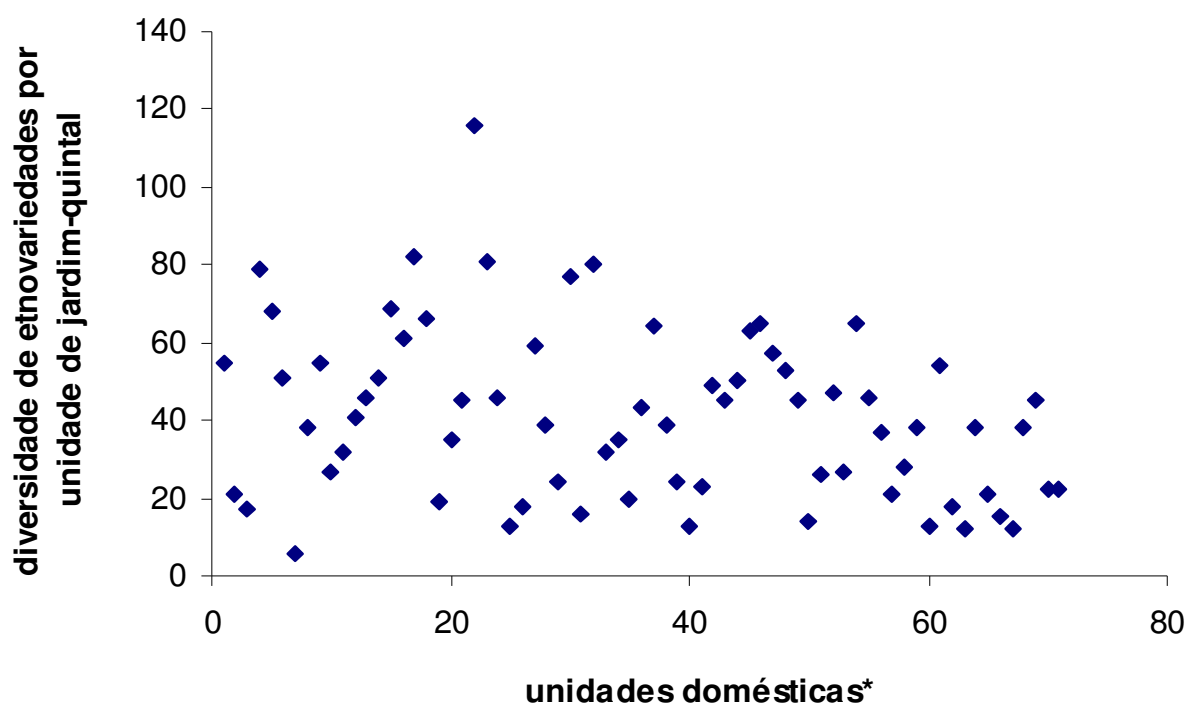

Figura 4.31: gráfico de dispersão relacionando diversidade de etnovariedades por unidade de jardim-quintal em função da classificação socioeconômica gerada pelo método de agrupamento hierárquico sem a inclusão do fator "liderança" (figura 40) ( ${ }^{*}$ unidades domésticas ordenadas de 1 a 71 segundo a classificação do dendograma da figura 4.29). 


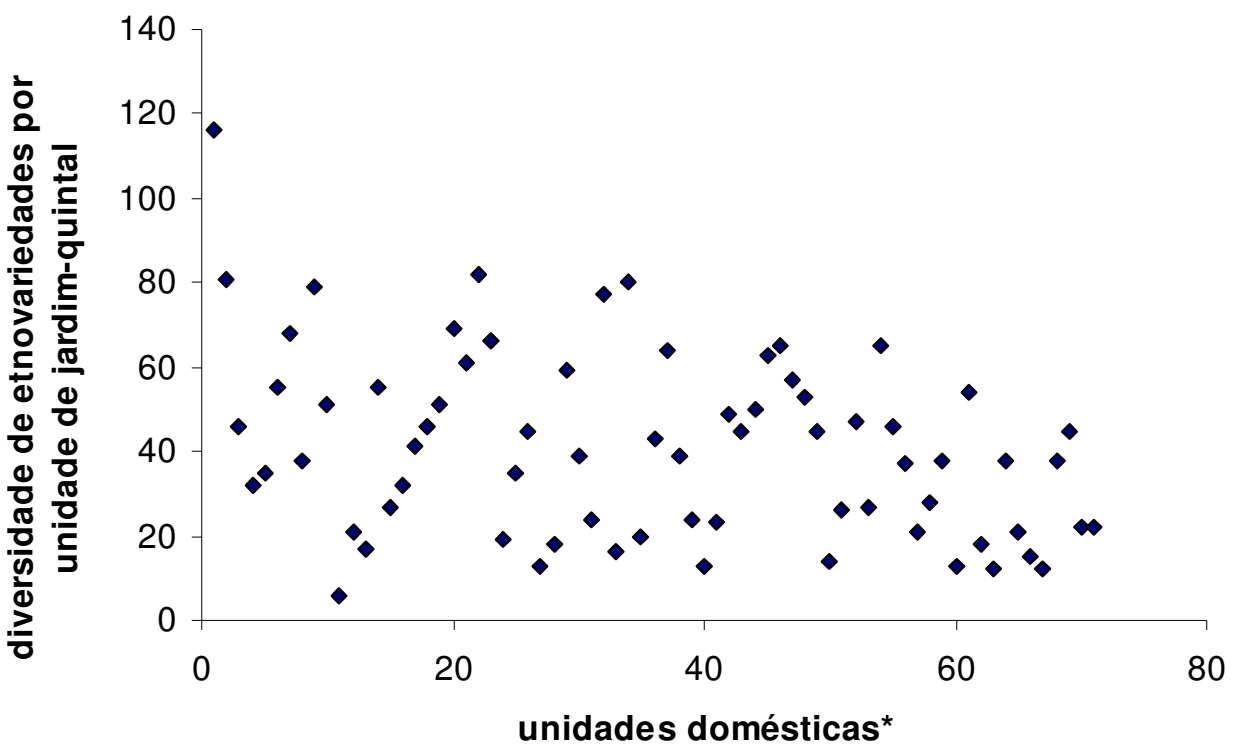

Figura 4.32: gráfico de dispersão relacionando diversidade de etnovariedades por unidade de jardim-quintal em função da classificação socioeconômica gerada pelo método de agrupamento hierárquico com a inclusão do fator "liderança" (figura 41) ( ${ }^{*}$ unidades domésticas ordenadas de 1 a 71 segundo a classificação do dendograma da figura 4.30). 


\section{CAPÍTULO 5 \\ DISCUSSÃO E CONCLUSÕES}

\subsection{Complexidade estrutural e diversidade florística}

Os jardins-quintal das comunidades quilombolas estudadas confirmaram-se como sistemas altamente complexos, tanto no âmbito da diversidade de etnovariedades que os compõem quanto no da diversidade de hábitos de vida vegetal e zonas de manejo observadas. Essa complexidade já foi previamente relatada por diversos autores para jardins-quintal de outras regiões tropicais no Brasil e no mundo (Albuquerque et al., 2005; Ali, 2005; Altieri, 1999; Amorozo e Gély, 1988; Blanckaert et al., 2004; Brito e Coelho, 2000; Caballero, 1992; Cerda e Mukul, 2008; Fernández e Nair, 1986; Figueiredo et al., 1997; Garrote, 2004; Hanazaki et al., 2000; Hanazaki, 2001; Kimber, 2004; Kumar e Nair, 2004; Lok et al., 1998; Murrieta e Winklerprins, 2003; Nair, 1993; Niñez, 1985; Ribeiro, 1996; Saragoussi, 1990; Soemarwoto et al., 1987). A grande complexidade estrutural e a alta diversidade etnovariedades dos jardins-quintal nas comunidades campesinas tropicais em todo o mundo refletem, em uma escala mais abrangente, a semelhança existente entre os sistemas agrícolas tropicais de coivara em escala global. Isso se deve provavelmente ao conjunto de características e limitações biofísicas comuns que os ambientes tropicais apresentam, e que requerem sistemas adaptativos semelhantes entre si para que se consolidem como conjuntos produtivos viáveis Boserup (1987), Conklin (1971), MacGrath (1987) e Pedroso-Júnior e colaboradores (2008a), reportam que, de fato, o sistema agrícola de coivara (ou agricultura itinerante de corte-e-queima) reúne características que o constituem como uma adaptação eficiente às limitações sociais e ambientais (fertilidade do solo, pestes microbiais, mão de obra) impostas pelo contexto vivenciado populações indígenas e campesinas dos trópicos úmidos. Dessa forma, a agricultura de coivara se consolidou amplamente como o principal componente dos sistemas de subsistência das populações pobres rurais em diversas regiões tropicais úmidas do mundo (Boserup, 1987; Conklin, 1971; MacGrath, 1987; Pedroso-Júnior et al., 2008a). Os sistemas complexos formados em torno da agricultura de coivara incluem, por sua 
vez, subsistemas que reúnem, como descrito anteriormente, áreas de silvicultura, áreas de roça e hortas próximas à unidade residencial, áreas de roça mais distantes da última (e que podem ou não ser temporárias), terrenos em descanso, jardinsquintais (Ali, 2005; Altieri, 1999; Altieri et al., 1987; Nair, 1993; Pedroso-Junior et al., 2008b; Posey, 1987; Soemarwoto e Soemarwoto, 1984; Sanches, 2004; Tsegaye 1997). Esta última subunidade, portanto, acompanha as semelhanças de estruturais e funcionais do todo no qual estão incluídas, considerando as mais diversas regiões tropicais nos quais o sistema agrícola em questão é praticado.

Com relação à complexidade florística em particular, a média de 40 etnovariedades distintas por jardim-quintal observada contempla não só uma grande multiplicidade de famílias biológicas, como também encerra em si diversas utilidades potenciais para a unidade doméstica (ver seção seguinte). Ainda assim, foi possível observar a existência de uma similaridade marcante entre as três comunidades estudadas com respeito à composição de algumas das principais etnovariedades predominantes em cada um dos seguintes componentes: arbóreo, arbustivo, herbáceo, lianas e epífitas. Esse aspecto é mais claro para as etnovariedades do componente herbáceo, especialmente as cultivadas nas hortas. Esta similaridade referente à composição florística entre diferentes regiões do Brasil foi encontrada também em outros trabalhos, e está de acordo com a proposta de que a escolha de cultivares - pelas mais diversas populações rurais do mundo - está amplamente ligada a um contexto social e ambiental específico (Albuquerque et al 2005, Figueiredo et al 1997, Garrote 2004, Hanazaki 2000). As comunidades quilombolas estudadas são geograficamente próximas, estão submetidas a um mesmo ambiente natural (fragmentos florestais de Floresta Atlântica sub-montana), e passaram por um processo histórico extremamente parecido. Sob essa ótica, as semelhanças na composição de etnovariedades dos jardins-quintal de Sapatu, Pedro Cubas e São Pedro tornam-se perfeitamente compreensíveis.

Com relação à estrutura vertical apresentada pelos jardins-quintal aqui investigados, foi observado um dossel vertical com 3 a 4 camadas. Esse mesmo padrão foi encontrado por Nair (1993) e Brito e Coelho (2000) com relação a esse mesmo subsistema em outras comunidades de pequenos produtores rurais dos trópicos, complementando a evidência de uma similaridade significativa entre os sistemas agrícolas tropicais. Com relação às zonas de manejo (ou, estrutura 
horizontal), confirmou-se a semelhança entre o padrão descrito por Lok e colaboradores (1998) para os jardins-quintal da península de Nicoya, Costa Rica e o encontrado nas comunidades quilombolas paulistas. As 7 zonas de cultivo que puderam ser identificadas para os jardins-quintal descritos neste trabalho têm composição e função bastante parecidas com as 5 zonas caracterizadas por Lok e colaboradores em seu trabalho de 1998, com algumas pequenas variações.

\subsection{Multifuncionalidade: transformação e diferenciação}

O potencial dos jardins-quintal como subsistema multifuncional foi confirmada para comunidades quilombolas investigadas neste trabalho, como anteriormente reportada por Fernadéz e Nair (1986), Nair (1993) e Kumar e Nair (2004) para outras regiões do mundo. Essa característica é mais um indicativo do panorama supracitado, referente à similaridade de estrutura e função dos sistemas agrícolas "tradicionais" das regiões tropicais úmidas.

Considerando particularmente as funções predominantes dos jardins-quintal, destacaram-se o papel das etnovariedades destinadas à alimentação da família e as cultivadas para "enfeitar" o espaço.

A importância dos jardins-quintal na dieta dos pequenos produtores rurais, fornecendo aos mesmos segurança alimentar e minimização dos riscos agrícolas, é uma questão amplamente reconhecida em estudos sobre sistemas agrícolas tradicionais (Fernadéz e Nair, 1986; Greenberg 1996; Kumar e Nair, 2004; Murrieta e WinklerPrins, 2003; Nair, 1993). No caso das comunidades reportadas neste trabalho, os jardins-quintal exercem um papel de complementação e diversificação da dieta das famílias, não sendo de maneira alguma a fonte principal de itens alimentares para a UD.

Já o cultivo de etnovariedades ornamentais pode ser considerado um produto recente da história agrícola da região investigada, e vem adquirindo cada vez mais destaque e importância para as famílias quilombolas em questão. No "tempo dos antigos", apenas algumas poucas espécies eram cultivadas com o objetivo predominantemente estético, como, por exemplo, as rosas (Rosa sp.). Neste 
trabalho, no entanto, foram levantadas diversas etnovariedades distintas com a função predominante (ou única) de "enfeitar" os jardins-quintal, muitas delas são tão "recentes" para a história agrícola da comunidade que o nome da planta não era conhecido pelo informante em campo. Esse processo este de acordo com o que propõe Boserup (1987) e Goody (1994) sobre o cultivo de flores (jardinagem) como produto da agricultura "avançada" e da complexificação social de uma determinada sociedade. A premissa do último autor é que o cultivo de flores não é um aspecto geral do comportamento humano, ligado à nossa base biológica, mas sim um aspecto cultural. As flores seriam parte da cultura tanto porque vieram a ser cultivadas pela humanidade, quanto porque são usadas na vida social (decoração, medicina, alimentação, cheiro, trocas, e estabelecimento de relações em vários âmbitos, como entre mortos e vivos, divindades e humanos, parentes, amigos) (Goody, 1994). Dessa forma, entende-se que um dos fatores explanatórios da razão pela qual as flores desempenham um papel quase inexistente no domínio artístico dos povos africanos (tanto visual quanto verbal) seria o fato de que haveria uma ligação entre o cultivo de flores (a jardinagem) e toda a história dos desenvolvimentos pós-neolitico (que sucedeu a segunda revolução agrícola) e decorrente do assentamento gradual seguido do processo de urbanização enfrentado pelos campesinos que baseavam seu sistema agrícola na itinerância e no pousio longo dos seus campos de cultivo (Boserup, 1987; Goody, 1994). Ou seja, "o cultivo de flores seria essencialmente produto da agricultura avançada, da jardinagem, então raramente encontramos tal cultivo em sistemas agrícolas simples", ou seja, sistemas pré-industriais baseados na coivara ou na enxada (Goody, 1994, p.20). O desenvolvimento agrícola, por outro lado, não deixaria de estar fortemente associado a determinados elementos das transformações sociais e econômicas mais abrangentes, como diversos estudos têm mostrado (Angelsen, 1995; Boserup, 1987; Bray et al., 2003; Byron e Arnold, 1999; Cardoso et al., 2001; Kulikoff, 1993; Kumar e Nair, 2004; McSweeney, 2005; Metzger, 2003; PedrosoJúnior, 2008; Pedroso-Júnior et al., 2008a e 2008b; Queiroz, 2006). Dentre estes elementos estão a incorporação de classes e sistemas de distinção social, aliada a entrada de valores urbanos no meio rural (Goody, 1994; Queiroz, 2006). A complexificação social decorrente dessa dinâmica altera também aspectos simbólicos da população que passa por esse processo, pensando que as 
necessidades humanas têm também um caráter social (além do biológico). Nesse caso, a apropriação simbólica, pelas comunidades quilombolas reportadas, de uma visão claramente mais "urbana" dos espaços de jardim-quintal, é refletida no aumento da função estética destas subunidades agrícolas para as famílias que as mantém.

Outro fator decorrente da entrada de elementos urbanos no meio rural referido é a multifuncionalidade dos jardins-quintal estudados, que está fortemente associada à grande diversidade de categorias de uso das etnovariedades nessas áreas (ou seja, sua grande diversidade florística). Foi observado um mínimo de 12 categorias de uso dentre as etnovariedades cultivadas, sendo que, freqüentemente, uma mesma espécie pode potencialmente exercer mais de uma função para a família. É importante considerar que houve um significativo aumento do número de táxons vegetais nos jardins-quintal em decorrência da série de transformações espaciais que vêm ocorrendo nas comunidades estudadas. Baseando-se nos relatos dos próprios informantes em campo (seção 4.7, p. 106), pôde-se observar de forma sumária que, a partir das últimas 6 décadas, iniciou-se de maneira significativa o processo de formação das vilas na região, resultando em uma forte aproximação das unidades domésticas entre si e em uma menor mobilidade dos roçados e das moradias associadas às áreas de roça mais longínquas - capuovas (Pedroso-Júnior, 2008; Pedroso-Júnior et al., 2008b). A valorização crescente das populações locais por elementos como a proximidade da moradia a centros escolares, médicos, disponibilidade de energia elétrica, e de oportunidade de trabalhos não necessariamente relacionados à agricultura, foram centrais nesse processo de aproximação das unidades domésticas e formação de pequenas vilas de moradores. Essa adequação (ou mudança) a novos valores faz parte do processo de urbanização das fronteiras agrícolas (comentado anteriormente) que vêm ocorrendo diversas comunidades campesinas ao redor do mundo (Browder e Godfrey, 1997). A urbanização das fronteiras agrícolas é um processo global, mas que pode apresentar particularidades marcantes referentes aos contextos locais nos quais está presente (seja em termos da velocidade das transformações associadas, na maneira em que estas transformações ocorrem, na profundidade e a extensão do processo de integração, ou nas motivações dos grupos envolvidos) (Browder e Godfrey, 1997). No caso aqui apresentado, as principais transformações econômicas 
e sociais ligadas ao processo supracitado que ocorreram no Médio Ribeira nas últimas 6 décadas (região onde se localizam as comunidades quilombolas referenciadas nesse trabalho), foram provenientes principalmente de uma política de Estado pautada no nacional-desenvolvimentismo do Regime militar brasileiro. Foi o poder público, portanto, que depois de décadas de marginalização econômica, se empenhou em inserir essa região no cenário nacional de maneira significativa. Apesar de não ter sido exatamente bem sucedida, essa política de inserção deixou marcas que permanecem até os dias de hoje, dentre elas: a presença de grandes fazendas formadas pela apropriação conflituosa de terras no período da grilagem; o cultivo de banana para a venda; e o fato de que a maior parte dos fatores-chave das mudanças supracitadas (escolas, centro médicos, energia elétrica) serem decorrência de políticas públicas de desenvolvimento social na região do Ribeira. A presença marcante do Estado nas comunidades quilombolas de Sapatu, São Pedro e Pedro Cubas ainda ocorre, e pode ser verificada, por exemplo, quando as famílias optam de maneira generalizada pela obtenção de créditos agrícolas do governo para desenvolverem parte de suas atividades econômicas.

Uma das principais conseqüências dessa inserção do meio rural em um meio cada vez mais urbano, na região estudada, é a submissão das "vilas" de moradores a leis de vigilância sanitária mais rigorosas, seguindo a tendência dos centros urbanos próximos. Dentre outros aspectos, isso trouxe para essas comunidades uma forte restrição à criação de animais nas áreas adjacentes ao complexo residencial, havendo uma diminuição significativa da criação de animais de corte (principalmente porcos, mas também galinhas e patos, principalmente) no espaço dos jardins-quintal. Esta redução também está aliada a fatores como a falta de espaço físico no entorno da casa (também resultante da aproximação das unidades domésticas e à formação de vilas), a falta de áreas disponíveis para lavoura de produção de forragem (principalmente o milho - Zea mays L.) e o desinteresse crescente entre os mais jovens por atividades agrícolas. Esse quadro de transformações levou a perda de uma função pretérita primordial dos jardins-quintal como espaço para "a criação", ou seja, produção de proteína animal. A diminuição significativa dessa atividade nos jardins-quintal atuais, por outro lado, permitiu a complexificação florística desses espaços, principalmente com relação à etnovariedades herbáceas ("as miudezas"), mas também com relação às espécies 
lenhosas ("as plantas duras"). Sendo assim, pode-se dizer que essas subunidades agrícolas acabaram adquirindo mais funções com o correr do tempo, já que sua diversidade florística (de etnovariedades ornamentais, medicinais e alimentares) nesses espaços também aumentou.

Além da questão da urbanização como um fator de transformação primordialmente espacial, é interessante pontuar pelo menos outros três aspectos que, seja de maneira direta ou indireta, influenciam as tomadas de decisão relativas aos espaços dos jardins-quintal: a mudança dos hábitos alimentares; o desinteresse crescente dos mais jovens em se envolverem com atividades agrícolas; e a imposição por lei de áreas protegidas no território de ocupação das comunidades. A mudança de hábitos alimentares e gostos contribuem para a diminuição do consumo de produtos não industrializados (incluindo os cultivares de roça e os presentes nos jardins-quintal), o que conseqüentemente leva a uma redução do interesse e esforço para manutenção e complexificação dessas subunidades agrícolas. O mesmo ocorre com o desinteresse dos mais jovens em se envolverem com atividades agrícolas. Ambos os fatores citados são, de certa maneira, também conseqüência da mudança de valores e certos aspectos culturais simbólicos dessas comunidades campesinas, advinda rede de transformações do processo de urbanização dessas fronteiras agrícolas (como discutido acima). As leis de áreas protegidas impostas no território ocupado pelas comunidades estimula a existe a tendência de um maior esforço de cultivo em áreas contíguas aos jardins-quintal (figura 4.28). Isso é percebido especialmente na comunidade de Sapatu - a que tem maior acessibilidade aos centros urbanos próximos (as UDs Sapatu se distribuem ao longo dessa mesma rodovia SP-165. São Pedro está a uma distância de 8 quilômetros dessa mesma rodovia, e Pedro Cubas a 12 quilômetros). Provavelmente nesta comunidade a diminuição dos custos de escoamento dos produtos agrícolas é mais pungente, de maneira o cultivo de variedades destinadas à comercialização - principalmente a banana (Musa sp.) - tornou-se ainda mais vantajoso nesse bairro. O fator "acessibilidade" (que pode ser encarado como um facilitador do processo de urbanização dessas fronteiras agrícolas) trouxe ainda duas distinções interessantes às comunidades quilombolas investigadas neste estudo. Em Sapatu, principalmente (e em São Pedro em uma segunda instância) há cultivo predominante de etnovariedades ornamentais e etnovariedades "recentes" com relação à comunidade 
de Pedro Cubas. As transformações nas técnicas e práticas agrícolas aceleradas pelo acesso facilitado nessas duas comunidades podem perfeitamente ter resultado nesse cenário (considerando o que foi discutido anteriormente sobre a proposta da Goody (1994) para variedades ornamentais). O fator acessibilidade pode se resumir não apenas à questão geográfica, mas também a questão de articulação da comunidade com a sociedade mais abrangente. Apesar não estar claro neste trabalho, o acompanhamento de parte da dinâmica social e econômica dessas três comunidades quilombolas durante cerca de 4 anos, leva a acreditar que essa articulação ocorre de maneira destacada na comunidade de São Pedro, o que contribuiria para as assunções aqui realizadas.

Das transformações discutidas anteriormente, é importante frisar, por fim, que o acúmulo crescente de funções dos jardins-quintal para as comunidades estudadas parece não ter uma relação direta com diversas motivações que vem levando ao abandono da abertura de novas áreas de roça. Isso é de certa forma reforçado pelo fato de que pouquíssimas etnovariedades são plantadas simultaneamente nos dois espaços, ou seja, não há sobreposição de função entre estas subunidades agrícolas. Outra maneira de perceber que os jardins-quintal não estão substituindo as áreas de roça per se é a constatação realizada neste trabalho de que das etnovariedades comumente plantadas nas capuovas ou áreas próximas ou contiguas as UDs (ou seja, o feijão (Phaseolus vulgaris L), a mandioca (Manihot esculenta Crantz), a banana (Musa sp.), o milho (Zea mays L) e o arroz (Oryza sativa $\mathrm{N}$ )), apenas a mandioca e banana são encontradas também nos jardinsquintal, e em muito menor abundância (Pedroso-Junior, 2008; Pedroso-Júnior et al., 2008b).

\subsection{Jardins-quintal: a parte feminina da agricultura}

Outro aspecto importante dos jardins-quintal quilombolas levantado neste trabalho é seu papel como espaço social. Esse fato possibilitou o uso dessa subunidade agrícola como modelo para análise da dinâmica e estruturação familiar, sendo seu layout e manejo reflexos do conhecimento do principal responsável pelo 
espaço, assim como observaram Lok e colaboradores (1998), Howard (2003) e Murrieta e WinklerPrins (2003). Nas comunidades estudadas, foram as mulheres que se revelaram como as principais mantenedoras dos jardins-quintal, resultado que se alinha a diversos outros estudos (Brito e Coelho, 2000; Figueiredo et al., 1997; Greenberg, 1996; Howard, 2003; Murrieta e Winklerprins, 2003; Tsegaye, 1997). Elas foram as informantes principais na maioria significativa dos levantamentos realizados. Além do importante trabalho nos jardins-quintal, as mulheres inevitavelmente auxiliam nas roças próximas e nas "capuovas" e cuidam da casa e dos filhos. De fato, têm-se relatado nos mais recentes estudos que as mulheres são as principais candidatas a iniciar os processos de domesticação e manejo de plantas. Sua proximidade ao complexo residencial, resultante de sua função primordial com relação aos cuidados com a casa e com os filhos, as torna as mais capacitadas para um cultivo mais efetivo e minucioso das plantas (Greenberg, 1996). Queiroz (2006), em estudo em Ivaporanduva (comunidade quilombola do Médio Ribeira) constatou que, de fato, "no interior de cada família obedecia-se à divisão das tarefas pelas linhas de sexo e idade (p. 44)" e que "a mulher que trabalhava na roça trabalhava em casa também: serviço de lavar a roupa, costurar, cozinhar... Esse era o serviço da mulher em casa" (p. 44). Apesar desse claro acúmulo de funções, as mulheres são muitas vezes negligenciadas em diversas sociedades mundiais, e geralmente tidas como não produtivas. Como discutido anteriormente, Tsegaye (1997) aponta como razões principais para esse negligenciamento a não remuneração na maioria dos serviços que realizam. Somase a isto o fato de as próprias mulheres normalmente não darem real valor ao seu trabalho e os homens serem considerados os chefes de família, o que os faz portavozes da unidade doméstica. Desse modo, a "voz" feminina é freqüentemente silenciada. Alheias a eventos sociais e políticos da comunidade, as mulheres correm o risco de inviabilizar ainda mais a sua contribuição à produção agrícola (Tsegaye, 1997). Dessa forma, o trabalho predominantemente feminino das mulheres nos jardins-quintal faz desses ambientes verdadeiras ferramentas potenciais de melhoria do papel da mulher nos processos de tomada decisão da família, principalmente no que se refere às negociações influenciadas por questões econômicas, diferenças de gênero, status social, tanto intra quanto inter unidade doméstica. (Murrieta e WinklerPrins, 2003). 


\subsection{Manejo}

O manejo dos jardins-quintal das comunidades quilombolas deste estudo confirma, de maneira geral, o padrão encontrado por Lok e colaboradores (1998) para a região de Nicoya (Costa Rica) com relação às estratégias básicas empregadas nesse espaço agrícola. São elas: a regulação da água e da umidade, a utilização de zonas de manejo, a tendência geral de manter - e se possível aumentar - a diversidade florística de espécies, e técnicas para melhoria nutricional do solo ou controle de pragas (através de insumos de fácil acesso no mercado ou de livre acesso no ambiente natural do entorno). Como foi possível depreender da descrição realizada no capítulo de resultados, de maneira geral, as práticas de manejo reportadas não possuem uma freqüência regular. A irrigação é, em geral, empregada em tempos muito secos ou em mudas recém plantadas. O plantio de novas etnovariedades não segue nenhum padrão relativo a períodos específicos do ano. As zonas de manejo são definidas pelo plantio de etnovariedades consideradas próprias para cada local, e pelo tipo de tratamento que é dado à vegetação e ao solo dessa mesma área (freqüência de capinagem, limpeza da área, etc.), sendo que ambas as atividades têm constância variável. O período do dia dedicado ao manejo do jardim-quintal também varia, bem como a freqüência com que esse manejo ocorre (segundo relatos dos próprios informantes). Poucas mudas (ou sementes) de etnovariedades são compradas. A maioria provém de rede de trocas com a vizinhança (parentes ou não), permaneceu no espaço como herança de moradores antigos (maioria parentes), ou, ainda, foi conseguido sem custos com instituições governamentais ou não-governamentais que atuam na região. Por fim, é importante considerar que não há uma rotina padrão de cuidados com o espaço ou com os cultivares, mas há uma relativa constância no investimento nesses espaços. Dessa forma, é possível entender que o quadro geral do manejo dos jardins-quintal dos quilombolas reportados requer poucos investimentos em quase todos os sentidos: financeiro, energético e de tempo. Esse panorama está em conformidade com o que se observa nas atividades agrícolas dos sistemas agroflorestais tropicais como um todo (Altieri et al., 1987; Altieri, 1999; Boserup, 1987; Pedroso-Júnior et al., 2008a; MacGrath, 1987). 


\subsection{Diferenças socioeconômicas entre as unidades domésticas}

A existência de grupos socioeconômicos distintos dentre as unidades domésticas das comunidades estudadas revela a heterogeneidade social e econômica nelas presente. Esse panorama pode ser um indicativo de que essa porção da população caipira negra paulista não impõe uma resistência significativa à organização de livre mercado (capitalista), moderna e industrial (Cancian, 1989), reforçando a vertente dos estudos de campesinato que entende que esse setor é essencialmente similar a qualquer outro setor da sociedade mais abrangente (Cancian, 1989), a despeito das diferenças culturais e históricas que o primeiro possa possuir. Porém, deve-se considerar que até mesmo o empenho dessas comunidades campesinas em preservar, fortalecer e reafirmar simbolicamente a força e a integridade de sua estrutura social para a própria comunidade é em grande parte uma resposta à pressão externa pela definição dessa identidade como moeda de troca pelo controle do uso do solo (titulação da terra). Dessa forma, torna-se ainda mais clara a relação dialética estreita entre os quilombolas paulistas e a sociedade do entorno.

A despeito desse cenário, as análises feitas neste trabalho (com relação especificamente aos espaços dos jardins-quintal das comunidades quilombolas de Sapatu, Pedro Cubas e São Pedro) não indicaram haver uma relação clara entre as diferenças socioeconômicas apontadas (ver também Pedroso-Júnior, 2008; Pedroso-Júnior et al., 2008b) e a diversidade florística das etnovariedades cultivadas nos jardins-quintal. Esse resultado pode sugerir que a não existência de uma relação entre esses dois fatores. Ou, ainda, que a investigação aqui empregada relacionando esses aspectos tenha sido demasiadamente simplista. Seriam necessários os aprimoramentos da avaliação e da seleção dos elementos sociais e econômicos utilizados nas análises aqui propostas, bem como a inclusão outros fatores mais complexos nessa mesma análise (como tomada de decisão individual e histórico familiar), para se chegar a uma conclusão mais sólida.

Estudos futuros podem lançar mão da ampla descrição e caracterização dos jardins-quintal quilombolas realizadas neste trabalho para aprofundar a relação entre 
as transformações estrutural e funcional desses espaços e as transformações sociais, econômicas e políticas das comunidades quilombolas paulistas.

\subsection{Conclusões}

Baseado no estudo desenvolvido nesta dissertação, podem ser tiradas as seguintes conclusões:

1) os jardins-quintal das comunidades quilombolas aqui referenciadas são sistemas agrícolas altamente complexos, tanto em seu aspecto estrutural quanto funcional;

2) estes subsistemas estão submetidos a transformações significativas, principalmente ao longo das 6 últimas décadas. Essas mudanças acompanham claramente a história agrícola da comunidade no qual estão inseridos, incorporando e se adaptando as alterações nas dinâmicas sociais e econômicas dessas populações;

3) a complexificação dos jardins-quintal está inversamente relacionada ao colapso da agricultura de coivara, mas não é sistema simplesmente substituto. Em outras palavras, o acúmulo de funções crescente nessas subunidades agrícolas não está diretamente ligado às diversas motivações que vem levando ao abandono da abertura de novas áreas de roça, afirmação confirmada pela não sobreposição de função entre as subunidades agrícolas citadas.

4) o processo de urbanização parece estar ocorrendo de maneira mais pungente naquelas comunidades que possuem acesso geográfico facilitado ou maior articulação política e econômica com a região do entorno;

5) as diferenças socioeconômicas existentes entre as unidades domésticas não se relacionam com a diversidade de etnovariedades dos jardins-quintal; 


\section{RESUMO}

\section{A Etnoecologia dos jardins-quintal e seu papel nos sistemas agrícolas tradicionais de populações quilombolas do Vale-do-Ribeira, São Paulo}

O presente trabalho propõe-se a investigar alguns aspectos referentes a estrutura e função de 71 jardins-quintais como subunidades dos sistemas agrícolas das comunidades quilombolas do Vale do Ribeira, município de Eldorado Paulista, São Paulo. Dessa forma, pretende-se compreender e problematizar a importância desses espaços no sistema produtivo agrícola mais abrangente desses caipiras negros, bem como as transformações pelas quais essas mesmas subunidades agrícolas vêm passando ao longo das últimas décadas. A agricultura itinerante uma das principais fontes de subsistência para populações humanas que habitam as florestas tropicais ao redor mundo. De maneira geral, os sistemas agrícolas baseiam-se criticamente na mão de obra familiar, sendo altamente influenciados pela organização social e dinâmica da unidade doméstica (Ali 2005, Pedroso-Júnior 2008, Pedroso-Júnior et al 2008). O estudo desses sistemas tem crescido em importância e visibilidade, com enfoque voltado principalmente para a dinâmica de roças e florestas. No entanto, a unidade jardim-quintal, até então considerada secundária na produção e reprodução doméstica, constitui um importante elo no entendimento das práticas agroflorestais locais. Para execução deste trabalho lançou-se mão de duas bases analíticas: uma qualitativa e etnográfica e a outra quantitativa e sistemática. As unidades de análise deste estudo foram o indivíduo e a unidade doméstica (UD). As mulheres foram as informantes-chave já que são reconhecidamente as principais mantenedoras de jardins e quintais. Assim, cada UD pesquisada teve uma informante. Os métodos utilizados para caracterizar e quantificar a composição e diversidade dos jardins e quintais foram questionários abertos e listagens livres. Para a descrição de alguns elementos estruturais e funcionais dos jardins-quintal foi utilizada a estatística descritiva. As comparações entre as comunidades estudadas foram realizadas através de testes de hipótese. A conjugação de dados socioeconômicos com os conjuntos de dados referentes aos jardins-quintal foi analisada utilizando-se a estatística multivariada. Os resultados mostraram que os jardins-quintal das comunidades quilombolas aqui referenciadas são sistemas agrícolas altamente complexos, tanto em seu aspecto estrutural quanto funcional, estando submetidos a transformações significativas principalmente ao longo das 6 últimas décadas. As diferenças socioeconômicas existentes entre as unidades domésticas não têm relação direta com a diversidade de etnovariedades dos jardins-quintal.

Palavras-chave: Agricultura de coivara. Jardins-quintal. Floresta Atlântica, Campesinato. Comunidades quilombolas. 


\section{ABSTRACT \\ The Ethnoecology of homegardens and its role in the agricultural systems of the quilombola communities of Ribeira Valley, São Paulo.}

This study aims to describe several aspects related to the structure and function of 71 homegardens which are here interpreted as subunities of the complex agricultural system present in the quilombola communities of the Ribeira Valley, municipality of Eldorado, SP. This description allows for the comprehension of the importance of these swidden plots in the productive systems of the caipiras negros, as well as for a better understanding of the several socioeconomic transformations that these homegardens have been going through during the last few decades. Agricultural systems are one of the most important subsistence activities for human populations that inhabit the tropical forests around the world. Generally, this productive systems are based on family labor, thus being strongly influenced by the social organization and the household dynamics (Ali, 2005; Pedroso-Júnior, 2008; Pedroso-Júnior, et al., 2008). Studies regarding these systems have grown in importance and visibility, mainly focused in the swidden lots and forests. However, the homegardens, until now considered a secondary activitie in the household production and reproduction, are gaining importance as an essential link for the understanding of the agroflorestal practices. This work is built on two analytical bases: a more qualitative and ethnographic one, and a more quantitative and systemic one. The units of analysis were the individual and the household (UD). Women were the key informants since they are recognized as the main keepers of the homegardens. Therefore, each studied UD had one informant. The methods used for the survey of homegarden plant diversity included open questionnaires and free listing. The description of homegardens structural and functional elements was done by means of descriptive statistics. Comparisons among the three studied quilombola communities were realized using hypothesis tests tools. The combination between de socioeconomic data and the data collected from homegardens was analyzed using cluster analysis. The results presented here show that the homegardens are a complex and diversified system, that have multiple functions (aesthetics, social, recreational and utilitarian) and several structural aspects. Also, they have been submitted to several and critical transformations at least during the last six decades. The socioeconomic differences among the households don't have any relationship with the diversity of local homegarden crops.

Key words: Slash-and-burn agriculture. Homegardens. Atlantic Rain Forest. Peasants. Quilombola communities. 


\section{REFERÊNCIAS CITADAS}

ADAMS, C. As florestas virgens manejadas. Boletim do Museu Paraense Emilio Goeldi. Série Antropologia, v. 10, n. 1, p. 3-20, 1994.

ADAMS, C. Caiçaras na Mata Atlântica: pesquisa científica versus planejamento e gestão ambiental. São Paulo: Annablume, 2000.

AIDAR, M.P.; GODOY, J.R.; BERGMANN, J.; JOLY, C.A. Atlantic Forest succession over calcareous soil, Parque Estadual Turístico do Alto Ribeira - PETAR, SP. Revista Brasileira de Botânica, v. 24, n. 4, p. 455-469, 2001.

ALBUQUERQUE, U.P.; ANDRADE, L.H.C.; CABALLERO, J. Structure and floristic of homegardens in Northeastern Brazil. Journal of Arid Environments, v. 62, Issue 1, p. 491-506, 2005.

ALCORN, J.B. Economic Botany, Conservation, and Development: what's the connection? Annals of Missouri Botanical Garden, vol. 82, p. 34-46, 1995.

ALI, A. M. S. Homergardens in Smallholder Farming Systems: Examples From Bangladesh. Human Ecology, v. 33, n. 2, p 245-270, 2005.

ALTIERI et al. Peasant Agriculture and the Conservation of Crop and Wild Plant Resources. Conservation Biology. v. 1, n. 1, p 49-58, 1987.

ALTIERI, M.A. Rethinking Crop Genetic Resource Conservation: A View From the South. Conservation Biology, v. 3, n. 1, p. 77-79, 1989.

ALTIERI, M.A. The ecological role of biodiversity in agroecosystems. Agriculture, Ecosystems and Environment. Vol. 74, p. 19-31, 1999.

AMOROZO, M.C. DE M., GÉLY. A. Uso de plantas medicinais por caboclos do Baixo Amazonas. Barcarena, PA, Brasil. Boletim do Museu Paraense Emilio Goeldi, Série Botânica, 4, 1988.

ANDERSON, A.B.; GELY, A.; STRUDWICK, J.; SOBEL, G.L.; PINTO, M.G.C.; Um sistema agroflorestal na várzea do estuário amazônico (Ilha das Onças, Município de Barbacena, Estado do Pará). Acta Amazônica, 15, p. 195-224, 1985. 
ANDRADE, T., PEREIRA, C.A., ANDRADE, M.R. (Eds). Negros do Ribeira: reconhecimento étnico e conquista do território. $2^{\mathrm{a}}$. Ed. São Paulo: ITESP: Páginas e Letras - Editora Gráfica, 2000.

ANGELSEN, A. Shifting Cultivation and "Deforestation": A Study from Indonésia. World Development. Vol.23, n.10, p. 1713-1729, 1995.

BALÉE, W. The Research Program of Historical Ecology. Annual Review of Anthropology, 35, p. 95-78, 2006.

BANERJEE, S.B. Who sustains whose development? Sustainable development and the reinvention of nature. Organization Studies, vol. 24, p. $143-180,2003$.

BARRERA-BASSOLS, N; TOLEDO, V.M. Ethnoecology of the Yucatec Maya: Symbolism, Knowledge and Management of Natural Resources. Journal of Latin American Geography, vol. 4, n. 1, p. 9-41, 2005.

BEGOSSI, A. Food diversity and choice, and technology in a Brazilian fishing community (Búzios Island, São Paulo State), 1989. Dissertação de doutorado University of California, Davis, 1989.

BEGOSSI, A. Métodos de Coleta e Análise de dados em Etonobilogia, Etnoecologia e disciplinas correlatas. Em: Anais do I seminário de Etnobiologia e Etnoecologia do Sudeste. Rio Claro: UNESP, 2002. 204p.

BEGOSSI, A. Ecologia Humana: Um Enfoque Das Relações Homem-Ambiente. Interciência, 18(1), p. 121-132, 1993.

BEGOSSI et al. Knowledge and the use of biodiversity in brazilian hot spots. Environment, Development and Susteinability. vol. 2, p.177-193, 2000.

BERNARD, H.R., Research Methods in Antropology: qualitative and Quantitative Approaches. London: Altamira Press, 1995.

BLANCKAERT et al. Floristic composition, plant uses and management practices in homegardens of San Rafael Coxcatlán, Valley of Tehuacán-Cuicatlán, Mexico. Journal of Arid Environments, vol. 57, p. 39-62, 2004. 
BOAS, F. Antropologia Cultural: textos selecionados. Tradução de Celso Castro. Rio de Janeiro: Zahar Editor, 2004. 109 p.

BOSERUP, E. Evolução agrária e pressão demográfica. Tradução de Oriowaldo Queda e João Carlos Duarte. São Paulo: Editora HUCITEC, Editora POLIS. 1987. $141 \mathrm{p}$.

BOX, G.E.O; STUART HUNTER, J.; HUNTER, W.G; Statistics for experimenters: design, innovation and discovery. New Jersey: John Wiley \& Sons Inc., 2005. 663 p.

BRAY et al. Mexico's Community-Managed Forests as a Global Model for Sustainable Landscapes. Conservation Biology, vol.17, No. 3, p. 672-677, 2003.

BRITO, M. A., COELHO, M. F. B., Os quintais agroflorestais em regiões tropicaisunidades auto-sustentáveis. Revista Agricultura Tropical, Cuiabá-MT, vol. 1, n. 4, p. 7-38, 2000.

BROSIUS, J.P. The Politics of Ethnographic Presence: Sites and Topologies in the Study of Transnational Movements. Em: New Directions in Anthropology \& Environment: Intersections. C. L. Crumley, E. van Deventer, J.J. Fletcher (eds), Boston: Altamira Press, p. 90-111, 2001.

BROWDER, J. O.; GODFREY, B.J. Raiforest Cities: urbanization, development, and globalization of the brazilian amazon. Londres: Columbia University Press, 1997. 429 p.

BROWN, D.; LUGO, A.E.. Tropical secondary forests. Journal of Tropical Ecology, vol.6, no.1, p. 1-32, 1990.

BYRON, N.; ARNOLD, J.E.M. What Futures for the People of The Tropical Forests? World Development, vol. 7, n. 5, p 789-805, 1999.

CABALLERO, J. Maya homegardens: past, present and future. Etnoecológica, vol.1, n.1, p.35-54, 1992.

CABALLERO, J. Use and management of Sabal palms among the Maya of Yucatán, 1994. Tese (doutorado) - Berkeley, University of California. 
CAMARGO, J.C.G.; PINTO, S.A.F., Estudo fitogeográfico e Ecológico da Bacia Hidrogáfica Paulista do Rio da Ribeira. 1971. Monografia - Faculdade de Filosofia, Ciências e Letras de Rio Claro, Rio Claro - SP.

CANCIAN, F. Economic Behavior in Peasant Communities. Em: Economic Anthropology, Stuart P. (Ed). California: Stanford University Press, 1989. p. 127170

CANDIDO, A. Os parceiros do Rio Bonito: estudo sobre o caipira paulista e a transformação dos seus meios de vida. São Paulo: Livraria Duas Cidades, 1971, 284 p.

CARDOSO, I.M. et al. Continual Learning for agroforestry system design: university, NGO and farmer partnership in Minas Gerais, Brazil. Agricultural Systems, n. 69, p. 235-257, 2001.

CARVALHO, M.C.P 2006. Bairros Negros do Vale do Ribeira: "do escravo" ao "quilombo", 2006, 199 p. Universidade Estadual de Campinas. Instituto de Filosofia e Ciências Humanas, Tese de Doutorado. 199 p.

CERDA, H. E. C.; MUKUL, R. R. G. Homergarden Production and Productivity in a Mayan Community of Yucatan. Human Ecology, 36, p. 423-433, 2008.

CHAYANOV, A. V. The Theory of Peasant Economy. Manchester: Manchester University Press, 1966. 307p.

CATTANEO, A.; SAN, N.N. The effects of Macroeconomic Factors on Deforestation in Brazil and Indonesia. Em: Slash and Burn Agriculture: the search for alternatives. Palm, Vosti, Sanchez e Ericksen (eds). New York: Columbia University Press, 2005. p. 170-196.

CONKLIN, H.C. The study of Shifiting Cultivation. Current Anthropology, vol. 2, n. 1, p. 27- 61, 1961.

CORLETT, R.T. What is Secondary Forest?. Journal of Tropical Ecology, vol. 10, Issue 3, p. 445-447, 1994.

CROCKETT, C.H. Hunt for Healing Plants Help Save Rainforests. Forum for Applies Research and Public Policy, 13, No. 1, p. 92-94, 1998. 
CROSBY, A.W. Imperialismo Ecológico: a expansão biológica da Europa: 9001900. São Paulo: Companhia das Letras, 1993. 319 p.

CUFFARO, N. Population Growth and Agriculture in Poor Countries: A Review of Theoretical Issues and Empirical Evidence. World Development, vol. 25, n. 7, p 1151-1163, 1997.

CUNHA, M. E ALMEIDA, M. W. B. Indigenous people, traditional people and conservation in the Amazon. Daedalus 129 (2): 315-338, 2000.

DAWSON,. The Marriage of Marx and Darwin? History and Theory, vol. 41, n., p.434-59, 2002.

DEAN, W. A botânica e a política imperial: a introdução e a domesticação de plantas no Brasil. Estudos Históricos. Rio de Janeiro, vol. 4, n. 8, p 216-228, 1991.

DEAN, W. A Ferro e Fogo: a história e a devastação da Mata Atlântica brasileira. Tradução de Cid Knipel Moreira. São Paulo: Companhia das Letras, 1996. 484 p.

DESCOLA, P.; PALSSON, G. Introduction. Em: Nature and Society: Anthropological Perspectives, Descola, P.; Palsson, G. (eds.), London: Routledge, p. 1-21,1996.

DIAMOND, J. Armas, Germes e Aço: os destinos das sociedades humanas. Editora Record, Rio de Janeiro/São Paulo, 4ª . Edição, 2003, 472 p.

DOVE, M.R. Interdisciplinary Borrowing in Environmental Anthropology and the Critique of Modern Science. Em: New Directions in Anthropology \& Environment: Intersections C. L. Crumley, E. van Deventer, J.J. Fletcher (eds.), Boston: Altamira Press, p. 90-111, 2001.

DA SILVA, H. A. Mandioca, a rainha do Brasil? Ascensão e queda da Manihot esculenta em São Paulo. Dissertação de mestrado. Departamento de História da Faculdade de Filosofia, Letras e Ciências Humanas da Universidade de São Paulo. 2008.

DUMONT, L. Marcel Mauss: uma ciência em devenir. Em: 0 individualismo: uma perspectiva antropológica da ideologia moderna, Rio de Janeiro, p. 179-199, 1985. 
DURKHEIM, E.; MAUSS, M. Algumas formas primitivas de classificação, 1903. Em: Ensaios de sociologia. Marcel Mauss, São Paulo: Ed. Perspectiva, 1981. p. 199455.

EMPERAIRE, L., AND ELOY, L. A cidade, um foco de diversidade agrícola no Rio Negro (Amazonas, Brasil)? Boletim do Museu Paraense Emilio Goeldi, Ciências Humanas, vol. 3, n. 2, 195-211, 2008.

ERIKSEN, T.H.; NIELSEN, F.S. História da Antropologia Rio de Janeiro: Editora Vozes. 2007.

ESCOBAR, A. After Nature: Steps to an Antiessentialist Political Ecology. Current Anthropology, 40 (1), p. 1-16, 1999.

EVANS-PRITCHARD, E.E. Os Nuer. São Paulo: Editora Perspectiva, 1978. 276 p.

FAIRHEAD, J.; LEACH, M. Misreading the African Landscape: Society and Ecology in a Forest-Savanna Mosaic. London: Cambridge University Press, 1996. $354 \mathrm{p}$.

FELD, S. A Poetics of Place: Ecological and Aesthetic Co-Evolution in a Papua New Guinea rainforest community. Em: Redefining Nature, R Ellen, K Fuku (eds), London: Berg Publications, p. 61-87, 1996.

FERNÁNDEZ, E.C.M.; NAIR, P.K.R. An evaluation of the structure and function of tropical homegardens. Agricultural Systems, vol.2, p.73-86, 1986.

FIGUEIREDO et al. Ethnobotany of Atlantic Forest Coastal Communities: Il. Diversity of Plants Uses at Sepetiba Bay (SE, Brazil). Human Ecology, vol.25, n. 2, p. 353360, 1997.

FREUDENBERG et al. Beyond Nature/ Society divide: learning to think about a mountain. Em: Sociological Forum, (10) 3, p. 361-92, 1995.

FUJISAKA et al. Weedy fields and forests: interactions between land use and the composition of plant communities in the Peruvian Amazon. Agriculture, Ecosystems and Environment. vol. 78, p. 175-186, 2000. 
FUNDAÇÃO SOS MATA ATLÂNTICA; INSTITUTO NACIONAL DE PESQUISAS ESPACIAIS. Atlas dos Remanescentes Florestais da Mata Atlântica - Período 2000 a 2005. Relatório Parcial. 2009. 156p.

GARROTE, V. Os Quintais Caiçaras, suas Características Sócio Ambientais e Perspectivas para a Comunidade do Saco do Mamanguá, Paraty-RJ. 2004. 198 p. Dissertação (mestrado) - Piracicaba, SP.

GILLISON, A.N. The Potential Role of Above-Ground Biodiversity Indicators in Assessing Best-Bet Alternatives to Slash and Burn. Em: Slash and Burn Agriculture: the search for alternatives. Palm, Vosti, Sanchez e Ericksen (eds), New York: Columbia University Press, p. 84-118, 2005

GODOY, R.; LUBOWSKI, R. Guidelines for the Economic Valuation of Nontimber Tropical-Forest Products. Current Anthropology, vol. 33, n. 4. p. 423-433, 1992.

GÓMEZ et al. Monitoring storage shelf life of tomato using electronic nose technique. Journal of Food Engineering, vol 85, p. 625-631, 2008.

GOODY, J. The culture of flowers. Cambridge: Cambridge University Press, 1994. $462 \mathrm{p}$.

GREENBERG, J.B.; PARK, T.K. Political Ecology. Journal of Political Ecology, 1, p. 1-12, 1994.

GREENBERG, L. S. You are what you eat: ethnicity and change in Yucatec immigrant house lots, Quintana Roo, Mexico, 1996. Tese (doutorado) - University of Wisconsin-Madison.

GRIFFITH, D.M. Agroforestry: a Refuge for Tropical Biodiversty after Fire. Conservation Biology, vol. 14, n.1, p. 325-326, 2000.

GUARIGUATA, M. R.; DUPUY, J. M. Forest regeneration in abandoned logging roads in lowland Costa Rica. Biotropica, 29, p. 15-28, 1997.

GUTJAHR, M.R. Critérios relacionados à compartimentação climática de Bacias Hidrográficas: A Bacia do Rio Ribeira de Iguape, 1993. Dissertação (mestrado) Faculdade de Filosofia, Ciências e Letras, Universidade de São Paulo. 
HAMMERSLEY, M.; ATKINSON, P. Ethnography: principles in practice. New York: Travistock Publications. 1983. 323 p.

HANAZAKI, N. Ecologia de Caiçaras: Uso de Recursos e Dieta. 2001. 402 p. Tese (doutorado) - Instituto de Biologia Universidade Estadual de Campinas.

HANAZAKI, N. et al. Diversity of plant uses in two Caiçara communities from the Atlantic Forest coast, Brazil. Biodiversity and Consevation, 9, p. 597-615, 2000.

HARRIS, D.R. The origins of agriculture in the tropics. American Scientist, vol.60, p.180-193, 1972.

HARWOOD, R.R. Development pathways toward sustainable systems following slash-and-burn. Agriculture, Ecosystems and Environment, vol. 58, p. 75$86,1996$.

HOGAN, D.J et al. Desenvolvimento sustentável no Vale do Ribeira (SP): conservação ambiental e melhoria das condições de vida da população. Ambiente \& Sociedade, ano II, n.3 e 4, 1999.

INSTITUTO BRASILEIRO DE GEOGRAFIA E ESTATÍSTICA (IBGE). Censo Demográfico 2000: características gerais da população. Rio de Janeiro: IBGE, 2000.

INSTITUTO BRASILEIRO DE GEOGRAFIA E ESTATÍSTICA (IBGE). Pesquisa nacional por amostra de domicílios: síntese de indicadores 2006. Rio de Janeiro: IBGE. 2006. 42 p.

INSTITUTO DE TERRAS DO ESTADO DE SÃO PAULO "JOSÉ GOMES DA SILVA" (ITESP). Relatório Técnico-Científico sobre os Remanescentes da Comunidade de Quilombo de Pedro Cubas de Cima/Eldorado-SP. São Paulo: 2003. 43 p.

INSTITUTO DE TERRAS DO ESTADO DE SÃO PAULO "JOSÉ GOMES DA SILVA" (ITESP) Relatório Técnico-Científico sobre os Remanescentes da Comunidade de Quilombo do Sapatu/Eldorado - SP. São Paulo: 2000. 57 p.

JOLY, C.A. et al. Evolution of the Brazilian phytogeography classification systems: implications for biodiversity conservation. Ciência e cultura, v.51, p.331-348, 1999. 
KIMBER, C.T. Gardens and Dwelling: People in Vernacular Gardens. Geographical Review, vol. 94, n. 3. p.263-283, 2004.

KLEINMAN, P.J., PIMENTEL, D. \& BRYANT, R.B. The ecological sustainability of slash-and-burn agriculture. Agriculture Ecosystem Environment, vol.52, n.2-3, p.235-249, 1995.

KOTTACK, C. The New Ecological Anthropology. Em: The Environment in Anthropology: A Reader in Ecology, Culture, and Sustainable Living, R. Wilk (ed.), New York: New York University Press, p. 40-52, 2006.

KULIKOFF, A. Households and Markets: Toward a New Synthesis of American Agrarian History. The Willian and Mary Quarterly, vol. 50, n. 3, p. 342 - 355, 1993.

KUMAR, B.M.; NAIR, P.K.R. The enigma of tropical homegardens. Agroforestry Systems, vol. 61, p. 135-152, 2004.

LOK, R. et. al. Influência de las características de sitio y el acceso al água em huertos de la Península de Nicoya, Costa Rica.. Em: Huertos Tradicionales de América Central: características e benefícios e importância desde um enfoque multidisciplinario, Lok, R. (Ed), Costa Rica: CATIE/AGUILA/ITR/ETC Andes, 29-60, 1998.

LORENZI, H.; MATOS. Plantas Medicinais no Brasil: nativas e exóticas cultivadas. São Paulo: Nova Odessa, Instituto Plantarum, $1^{\underline{a}}$ ed. 2002. 513 p.

LORENZI, H.; SOUZA, V.C. Plantas ornamentais no Brasil: arbustivas, herbáceas e trepadeiras. São Paulo: Nova Odessa, Instituto Plantarum. $3^{\underline{a}}$ ed. 2001. $1088 \mathrm{p}$.

McGRATH, D.G. The role of biomass in shifting cultivation. Human Ecololgy, vol.15, n.2, p.221-242, 1987.

MADRIGAL, L. Statistics for Anthropology. Cambridge University Press. 1998. 340 p.

MALINOWSKI, B. Uma teoria científica da cultura. Rio de Janeiro: Zahar Editores, 1975. $206 \mathrm{p}$.

MALINOWSKI, B. Argonautas do Pacífico Ocidental: um relato do empreendimento e da aventura dos nativos nos arquipélagos da Nova Guiné, 
Melanésia. Tradução de Anton P. Carr e Lígia Aparecida Cardieri Mendonça. São Paulo: Abril Cultural, 1984.

MATAVALE, J.; HABIB, M. Ethnobotany in Cabo Delgado, Mozambique: use of medicinal plants. Environment, Development and Sustainability, 2, p. 227-234, 2000.

MAUSS, M.; HUBERT, H. Esboço de uma teoria geral da magia (1902-3). Em: Sociologia e Antropologia. Tradução Paulo Neves. São Paulo: COSAC\&NAYF, 2003. $535 \mathrm{p}$.

MAUSS, M. (a) A Prece (1909) Em: Marcel Mauss: Antropologia, Roberto Cardoso Oliveira (org.), São Paulo: Ática, 1979.

(b) A Expressão Obrigatória de Sentimentos (1909), Em: Marcel Mauss: Antropologia, Roberto Cardoso Oliveira (org.), São Paulo: Ática, 1979.

McCABE, T. Cattle Bring us to our Enemies: Turkana Ecology, Politics, and Raiding in a Disequilibrium System. Michigan: University of Michigan Press, 2004. $301 p$.

MCSWEENEY, K. Indigenous Population Growth in the Lowland Neotropics: Social Science Insights for Biodiversity Conservation. Conservation Biology, vol. 19, n. 5, 2005.

METZGER, J.P. O que é ecologia de paisagens? Biota Neotropica, Campinas/SP, vol. 1, n. 1/2, p 1-9, 2001.

J.P. (a). Estratégias de conservação baseadas em múltiplas espécies guarda-chuva: uma análise crítica. Em: Ecossistemas brasileiros: manejo e conservação, Claudino-Sales, V. (org.), Fortaleza: Expressão Gráfica e Editora, p. 25-30, 2003.

J.P. (b) Effects of slash-and-burn fallow periods on landscape structure. Environmental Conservation, 30 (4): 325-333, 2003.

MIRANDA, E.E.; MATTOS, C. Brazilian rain Forest Colonization and Biodiversity. Agriculture, Ecosystems and Environment, 40, p. 275-296, 1992. 
MITHEN, S. Pré-história da Mente: Uma Busca das Origens da Arte, da Religião e da Ciência. São Paulo: Editora UNESP, 2003. 424 p.

MOORE, D. Marxism, Culture, and Political Ecology: Environmental Struggles in Zimbabwe's Easter Highlands. Em: Liberation Ecologies: Environment, Development Social Movements, R. Peet e M.Watts (eds.), London: Routledge, p. 125-147, 1997.

MORAN E.F. Ecosystem ecology in biology and anthropology: a critical assessment. Em: The Ecosystem Approach in Anthropology: From Concept to Practice, E.F Moran (ed.), The University of Michigan Press, Ann Arbor, p. 3-40, 1991.

MURRIETA, R.S.S.; WINKLERPRINS, A. Flowers of Water: Homegardens and Gender Roles in a Riverine Caboclo Community in the Lower Amazon, Brazil. Culture \& Agriculture, vol. 25, n 1, p. 35-47, 2003.

MURRIETA, R.S.S. Dialética do Sabor: Escolhas Alimentares, Ecologia e Vida Cotidiana em Comunidades Ribeirinhas da llha de Ituqui, Pará, Brasil. Revista de Antropologia da Universidade de São Paulo, 44 (2), p. 39-88, 2001.

MUSSOLINI, G. Ensaios de antropologia indígena e caiçara. Rio de Janeiro: Paz e Terra, 1980.

MYERS, N. Threatened biotas: hotspots in tropical forests. The Environmentalist, 8, p. $178-208,1988$.

NAIR, P.K.R. An introduction to Agroforestry. The Netherlands: Kluwer Academic Publishers. 1993. 449p.

NETTING, R.M. Intensive agriculture, population density, markets, and the smallholder adaptation. Em: Smallholders, Householders: Farm Families and the Ecology of Intensive, Sustainable Agriculture. Stanford: Stanford University Press, p. 261-294, 1993.

NEVES, W.A. Antropologia Ecológica. Um Olhar Materialista Sobre As Sociedades Humanas. São Paulo (SP): Cortez, vol.1, p. 86, 1996.

NIÑEZ, V. Working a half potential: constructure analysis of home garden programmes in the Lima slums with suggestions for an alternative approach. Food and Nutrition. Bulletin, 7(3), p. 8-14, 1985. 
ODUM, E.P. Fundamentos de Ecologia. $6^{\mathrm{a}}$ ed. Lisboa: Fundação Calouste Gulbenkian. 2001. 927p

OLIVEIRA, R.C. O Trabalho do Antropólogo: Olhar, Ouvir, Escrever. Revista de Antropologia, vol. 39, n.1, p. 13-37, 1996.

OLMOS et al. O impacto dos Guarani sobre as Unidades de Conservação em São Paulo. Terras Indígenas e Unidades de Consevação da Natureza. 1-17p, 2004.

ORLOVE, B.S.; BRUSH, S.B. Anthropology and the conservation of biodiversity. Annual Review of Anthropology, vol. 25, p. 329-52, 1996.

ORLOVE, B. J. Ecological Anthropology. Annual Review of Anthropology, 9, p. 235-273, 1980.

PAES, GABRIELA SEGARRA MARTINS. A "Recomendação das Almas" na Comunidade Remanescente de Quilombo de Pedro Cubas. 2007. Dissertação (Mestrado em História) - Universidade de São Paulo. 137p.

PATERSON, B. Ethics for Wildlife Conservation: Overcoming the Human-Nature Dualism. BioScience, vol. 56, n.2, p. 144-150, 2006.

PEDROSO-JÚNIOR, N.N. Do caminho dos antigos: agricultura de corte-equeima e intensificação agrícola em populações quilombolas do Vale do Ribeira, SP. 2008. 201 p. Tese (doutorado) - Universidade de São Paulo. Instituto de Biociências.

PEDROSO-JUNIOR, N.N., MURRIETA, R.S.S., ADAMS, C. A agricultura de corte e queima: um sistema em transformação. Boletim do Museu Paraense Emilio Goeldi: Ciências Humanas. Belém, vol. 3, n.2, p. 153-174, 2008 (a).

PEDROSO-JUNIOR, et al. A casa e a roça: socioeconomia, demografia e agricultura em populações quilombolas do Vale do Ribeira, São Paulo, Brasil. Boletim do Museu Paraense Emilio Goeldi: Ciências Humanas. Belém, vol.3, n.2, p. 227-250, 2008 (b).

PEREIRA DE QUEIROZ, M. I. O campesinato brasileiro: ensaios sobre civilização e grupos rústicos no Brasil. Petrópolis : Vozes, Coleção Estudos brasileiros; 3. 1973. 242p. 
PEREIRA, C. A.; VIEIRA, I. C. G. A importância das florestas secundárias e os impactos de sua substituição por plantios mecanizados de grãos na Amazônia. Interciência, v. 26, p. 337-341, 2001.

PETERS, C.M. Beyond Nomenclature and Use: A Review of Ecological Methods for Ethnobotanists. Em: Selected Guidelines for Ethnobotanical Research: A Field Manual. p. 241-276. 1996.

PERONI, N.; HANAZAKI, N. Current and lost diversity of cultivated varieties, especially cassava, under swidden cultivation system in the Brazilian Forest. Agriculture, Ecosystems and Environment, vol.92, n.2-3, p.171-202, 2002.

POSEY, D.A. Manejo da floresta secundária, capoeiras, campos e cerrados (KAYAPÓ). Etnobiologia, Suma Etnológica Brasileira, Petrópolis: vol.1, p. 173 185, 1987.

PRADO, P.I.K.L. \& LEWINSOHN, T.M. 0 Uso de Análises Multivaridas Ecológicas em Estudos Ambientais Interdisciplinares. (Cadernos Qualidade Ambiental e Desenvolvimento regional nas Bacias dos Rios Piracicaba e Capivari, Vol. 5), Campinas, NEPAM, 1998.

PRANCE et al. Quantitative ethnobotany and the case for conservation in Amazonia. Conservation Biology, vol 1, p. 296-310, 1987.

QUEIROZ, R.S. Caipiras negros no Vale do Ribeira: um estudo de Antropologia Econômica. Ensaios de Cultura. São Paulo: Ed. Edusp. 2ª Ed., 2006. 116p.

RAPPAPORT R. A. Ritual, Sanctity, and Cybernetics. American Anthropologist, 73, p. 59 - 76, 1971.

REDCLIFFE-BROWN, A.R. Estrutura e Função nas Sociedades Primitivas. Lisboa: Edições 70.329 p.

REDCLIFT, M.; WOODGATE, G. Sustainability and Environmental Change. Em: The International Handbook of Environmental Sociology, Redclift, M. e Woodgate, G. (eds.), Northampton, MA: Edward Elgar, p.55-70, 1997.

REIS, E. Estatística Multivariada Aplicada. Lisboa: Edição Sílabo, 2001. 343 p. 
RELATÓRIO DE BRUNTLAND, 1987. Em: Comissão Mundial Sobre Meio

Ambiente E Desenvolvimento. Nosso futuro comum. Rio de Janeiro, Ed. Fundação Getúlio Vargas. 1991. 430 p.

RIBEIRO, L.M.P. Aspectos etnobotânicos numa área rural - São João da Cristina. 1996. 339 p. Dissertação (mestrado). Universidade Federal do Rio de Janeiro. Rio de Janeiro.

RICO-GRAY, V. et. al. Species composition, similarity, and structure of Mayan Homegardens in Tixpeual and Tixcacaltuyub, Yucatan, Mexico. Economic Botany, 44: 470-487. 1990

ROBINSON, J.G. The Limits to Caring: Sustainable Living and the Loss of Biodiversity. Conservation Biology, vol. 7, n. 1, p. 20-28, 1993.

SALDARRIAGA, J.G.; UHL, C. Recovery of forest vegetation following slash-andburn agriculture in the upper rio Negro. Em: Tropical rain forest: regeneration and management, A. Gomez-Pompa, T.C. Whitmore e M. Hadley (eds.). New York: Blackwell, p. 303-312, 1991.

SANCHES, R. A. Caiçaras e a Estação Ecológica de Juréia-Itatins: litoral sul de São Paulo. São Paulo: Annablume (FAPESP), 2004. 207p.

SARAGOUSSI, M.; MARTEZ, J.H.I; RIBEIRO, G.A. Comparação na composição de quintais de três localidades de terra firme do estado do Amazonas. Em: Posey, D.A., Overal, W.L. (Eds). Ethnobiology: Implications and Applications - Proceedings of the First International Congress of Ethnobiology. Belém: Museu Paraense Emilio Goeldi, p. 295-303, 1990.

SCHWARTZMAN et al, Arguing Tropical Forest Conservation: People Versus Parks. Conservation Biology, vol. 14, n. 5, p. $1370-1374,2000$.

SECRETARIA DO MEIO AMBIENTE. Resoluções da Secretaria do Meio Ambiente: coletanea 1996. Sao Paulo: CETESB. 1996

SETZER, J. Atlas Climático e Ecológico do Estado de São Paulo. Comissão Interestadual da Bacia Paraná-Uruguai, 1966. 61p.

SOEMARWOTO, O., AND I. SOEMARWOTO. The Javanese rural ecosystem. Em: An introduction to human ecology research on agricultural systems in 
Southeast Asia, A.T. Rambo and P.C. Sajise (eds), University of the Philippines, Los Banos. . p. 254-287, 1984.

SOEMARWOTO, O. et al. The Javanese home gardens as an integrated ecosystem: science for better environment. Em: Proceedings of the International Congress Human Environment. Tokyo, Science Council of Japan, p.193-195, 1987.

SOUZA, V. C; LORENZI, H. Botânica Sistemática: Guia ilustrado para identificação das famílias de Angiospermas da flora brasileira, baseado em APG II. Nova Odessa: Instituto Plantarum. 2005. 640 p.

STEWARD, J. The Concept and Method of Cultural Ecology. Em: Theory of Culture Change, J. Steward (ed), University of Illinois Press, Urbana, p. 30-42, 1955.

STONE, M.P. Is Sustainability for Development Anthropologists? Human Organization, 62(2), p. 93-101, 2003.

SUTTON, P. Environment, self and society. Em: Nature, Environment and Society. Houndmills, Basingstone, Hampshire: Palgrave - Macmillan, p. 173-84, 2004.

TABARELLI, M., MANTOVANI, W. A regeneração de uma floresta tropical montana após corte e queima (São Paulo-Brasil). Revista Brasileira de Biologia, vol.59, n.2, p.239-250, 1999.

THEODOROVICZ, A. AND THEODOROVICZ, A.M.G. Atlas geoambiental: subsídios ao planejamento territorial e à gestão ambiental da bacia hidrográfica do Rio Ribeira do Iguape. 2aㅡ ed. Rev. São Paulo: CPMR (Serviço Geológico do Brasil). 2007.

TOREZAN, J.M.D. Estudo da sucessão Secundária na floresta ombrófila densa sub-montana, em áreas anteriormente cultivadas pelo sistema de "coivara", em Iporanga, 1995. Dissertação (mestrado) - Universidade Federal do Paranã, Curitiba, PR.

TSEGAYE, B. The significance of biodiversity for sustaining agricultural production and role of women in the traditional sector: the Ethiopian experience. Agricultural, Ecosystems and Environment, 62, p. 215-227, 1997. 
TSING, A. Nature in the making. Em: New Directions in Anthropology \& Environment: Intersections, C. L. Crumley, E. van Deventer, J.J. Fletcher (eds), Boston: Altamira Press, p. 3-23, 2001.

VALLE, T.L. Coleta de Gemoplasma de Plantas Cultivadas. Em: Métodos de Coleta e Análise de dados em Etonobilogia, Etnoecologia e disciplinas correlatas. Anais do I seminário de Etnobiologia e Etnoecologia do Sudeste. Rio Claro: UNESP, 204p, 2002.

VARA, A. La dinámica de la Milpa en Yucatán: el solar. Em: Hernández, X. (Ed). Seminário sobre Producción Agrícola em Yucatán. Secretaria de Programación y Presupuesto, Mérida, 1980.

VIERTLER, R.B. Métodos antropológicos como ferramenta para estudos em Etnobiologia e Etnoecologia. Em: Métodos de Coleta e Análise de dados em Etonobilogia, Etnoecologia e disciplinas correlatas. Anais do I seminário de Etnobiologia e Etnoecologia do Sudeste. Rio Claro: UNESP, 2002. 204 p.

VIVEIROS DE CASTRO. Perspectivismo e Multinaturalismo na América Indígena. Em: A Inconstância da Alma Selvagem e outros Ensaios. São Paulo: Cosac \& Naify, p. 345-400, 2002.

WATTS; PEET. Liberating political ecology. Em: Liberation Ecologies. Environment, Development, Social Movements, Peet \& Watts (eds). London e New York: Routledge, pgs. 3-47, 2004.

WEHLING, P. Dynamic constellations of the individual, society and nature: critical theory and environmental sociology. Em: Sociological Theory and the Environment. Classical Foundations, Contemporary insights, Dunlap, Buttel, Dickens e Gijswijt (eds). Lanham, Boulder, New York e Oxford: Rowman e Littlefield, p. 144-66, 2002.

WHITE, L. Energy and the evolution culture. American Athropologist, 45, p. 335356, 1943.

WHITE, L. Energy and Tools. Em: The Environment in Anthropology: A Reader in Ecology, Culture, and Sustainable Living, R. Wilk (ed.), New York: University Press,. p 123-135, 2006.

WOLF, E. "Types of Latin American Peasantry: A preliminary discussion". American Anthropologist, 57, p. 452-471. 1955. 
205. 1972.

Ownership and Political Ecology. Anthropological Quarterly, 45, 3, p. 201-

Tipos de campesinato latino-americano: uma discussão preliminar. Em: Antropologia e Poder: Contribuições de Eric Wolf. Feldman-Bianco, B. e Ribeiro, G. L. (Eds). São Paulo, Campinas, Brasília: Editora da Unicamp, Imprensa Oficial, Editora da UnB, p. 117-144, 2003.

WOORTMANN, E.F. Teorias do Campesinato. Em: Herdeiros, Parentes e Compadres: Colonos do Sul e Sitiantes do Nordeste. São Paulo, Brasilia: Editora Universidade de Brasília (Fundação Universidade de Brasília), p. 29 - 66, 1995.

ZENT, S. Behavioral Orientations toward Ethnobotanical Quantification. Em: Selected Guidelines for Ethnobotanical Research: A Field Manual. p. 199-239. 1996. 


\section{Apêndice A}

Tópicos principais das entrevistas semi-estruturadas (organização do trabalho familiar voltado para os jardins-quintal, as técnicas e dificuldades de manejo do espaço e alguns elementos do histórico da UD):

i) nome e idade do informante;

ii) onde nasceu (e onde os pais nasceram);

iii) onde morava quando criança;

iv) como era o jardim-quintal da UD onde morava quando criança;

v) se conheceu os avós, como era o jardim-quintal dos avós;

vi) se os pais possuíam área de roça longínquas (e o que plantavam);

vii) se essas áreas longínquas possuíam paiol;

viii) o que era plantado "na beira" do paiol (e se possuíam animais domésticos no local);

ix) onde foi morar depois que se casou ou se amaziou;

x) se chegou a ir trabalhar em outras cidades;

xi) quando veio morar na UD atual;

xii) quantas pessoas moram na UD atual;

xiii) o que possui de criação no jardim-quintal (e o que comem);

xiv) se "antigos" possuíam mais tipos ou quantidade de animais (e porque);

xv) qual a rotina diária (e se trabalha fora ou estuda);

xvi) quem participa mais da manutenção e plantio de variedades no jardimquintal;

xvii) se há outras ajudas para o manejo do espaço (e quem);

xviii) se utiliza algum fertilizante ou outro tipo de insumo agrícola no solo;

xix) se molha as plantas (quais e com qual freqüência);

xx) quais os principais problemas enfrentados no plantio e manutenção das etnovariedades dos jardins-quintal; 


\section{Apêndice B}

Questionários abertos (levantamento florístico):

i) nome da planta;

ii) quem plantou;

iii) onde conseguiu a muda;

iv) se lembra dessa variedade no tempos dos avós (se não, no tempo dos pais);

v) uso (qual e como utiliza);

vi) se possui a mesma variedade nas áreas de roça ou não;

vii) se vende a produção referente àquela variedade;

viii) quais os meses de floração;

ix) quais os meses de frutificação;

x) se há um tempo melhor para o plantio;

xi) quanto tempo demora para produzir (para o caso de algumas alimentícias não perenes);

xii) hábito de vida (anotado no momento pelo pesquisador); 


\section{Apêndice C}

Croquis e perfil-diagrama dos jardins-quintal de algumas unidades domésticas das comunidades quilombolas de Sapatu, Pedro Cubas, São Pedro, município de Eldorado Paulista, São Paulo.

Croqui da UD de Vilma, 29, Pedro Cubas. Não está em escala natural.

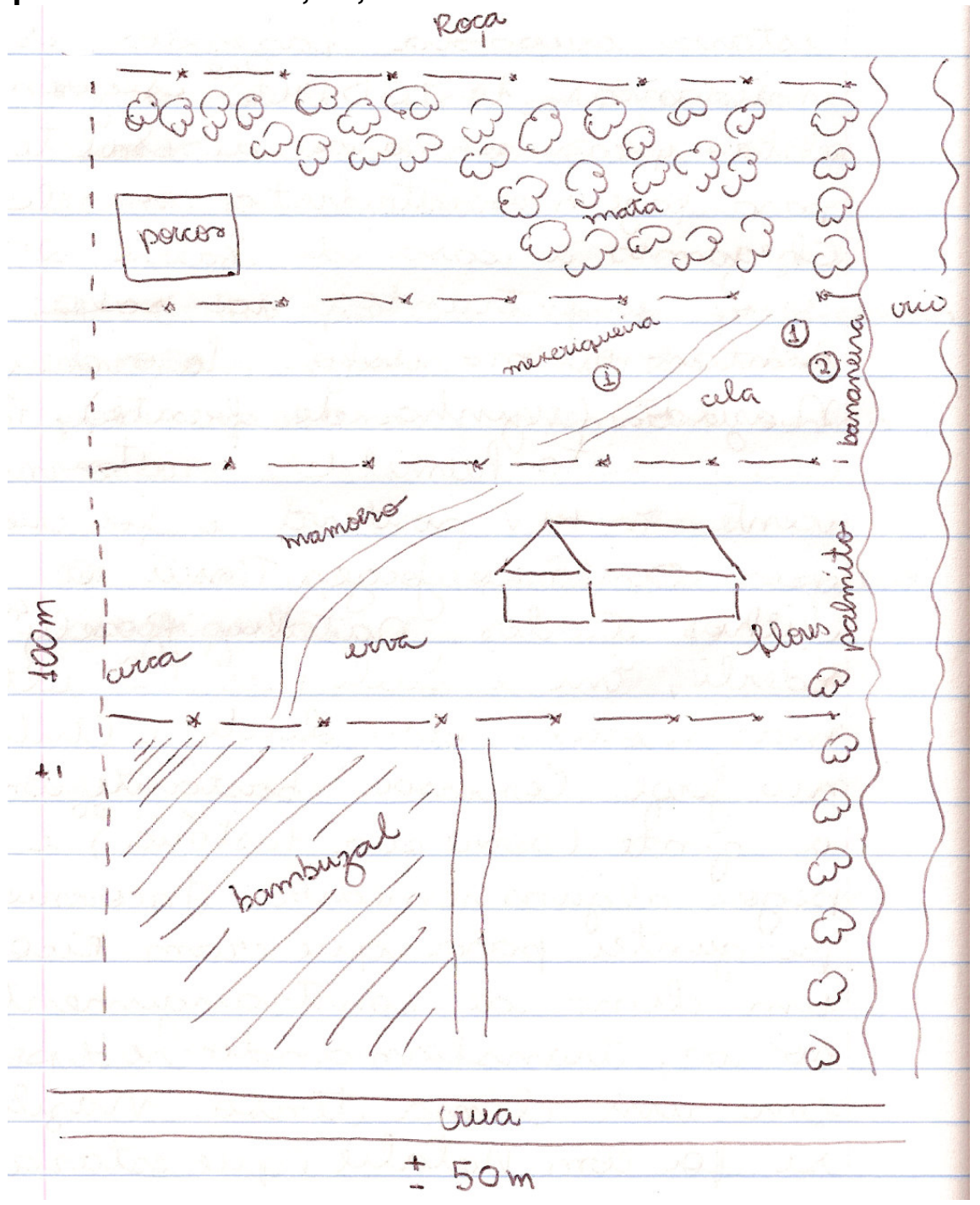


Croqui da UD de Nice, 36, São Pedro. Não está em escala natural.

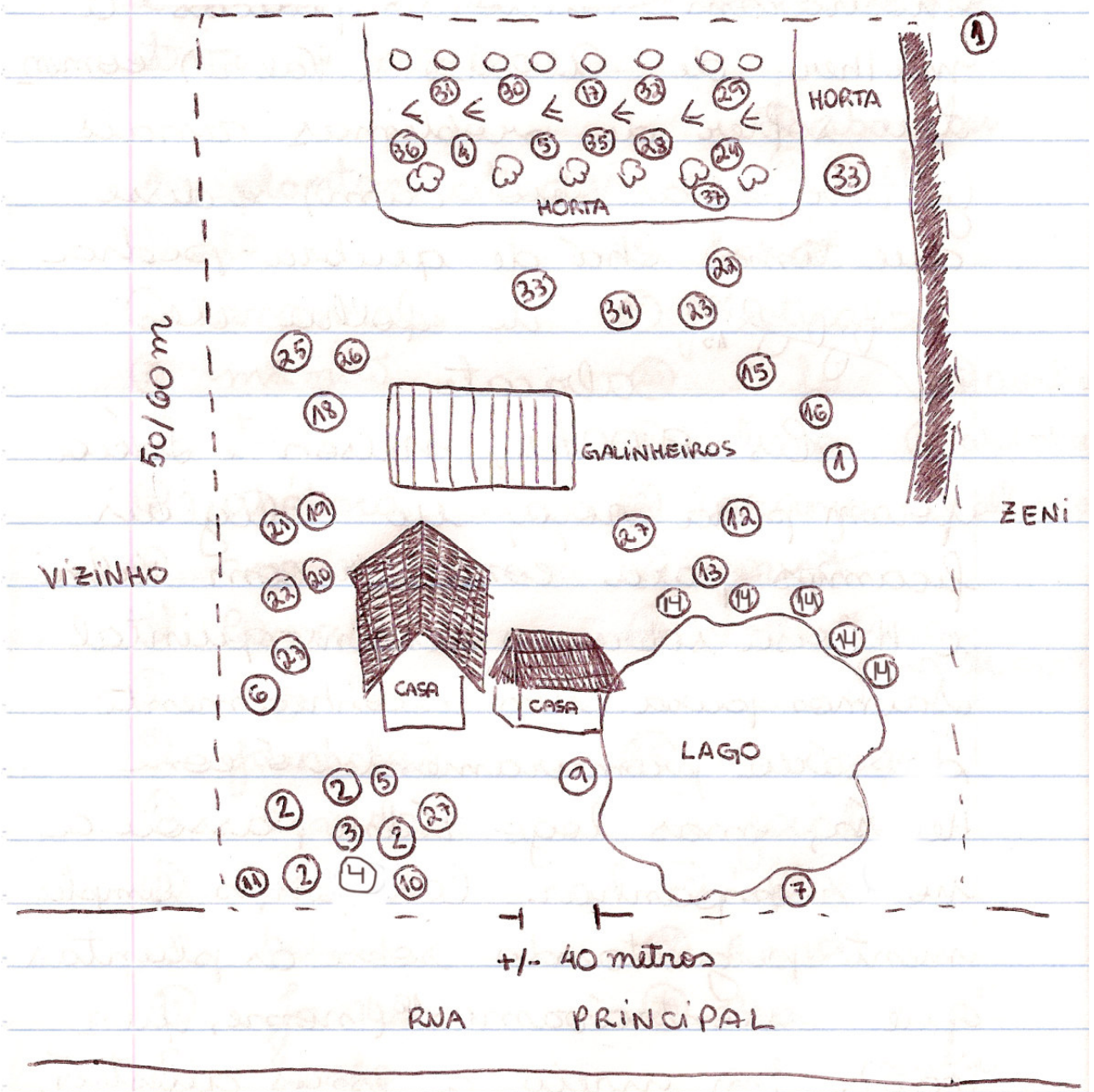


Croqui da UD de Nide, 45, Sapatu. Não está em escala natural.

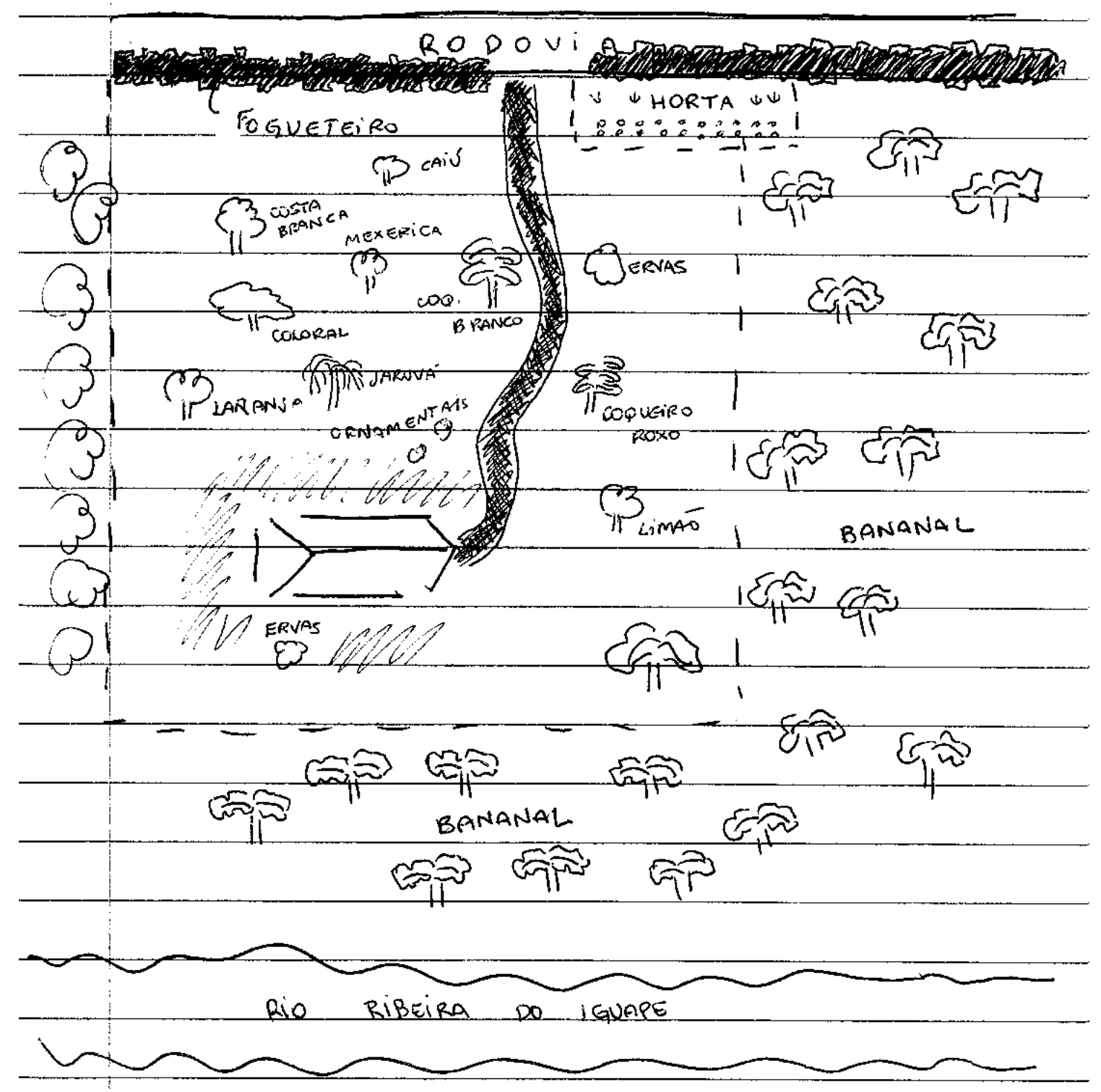


Perfil diagrama da estrutura vertical do tipo predominante de jardimquintal dentre as comunidades quilombolas de Sapatu, São Pedro e Pedro Cubas, Vale do Ribeira.

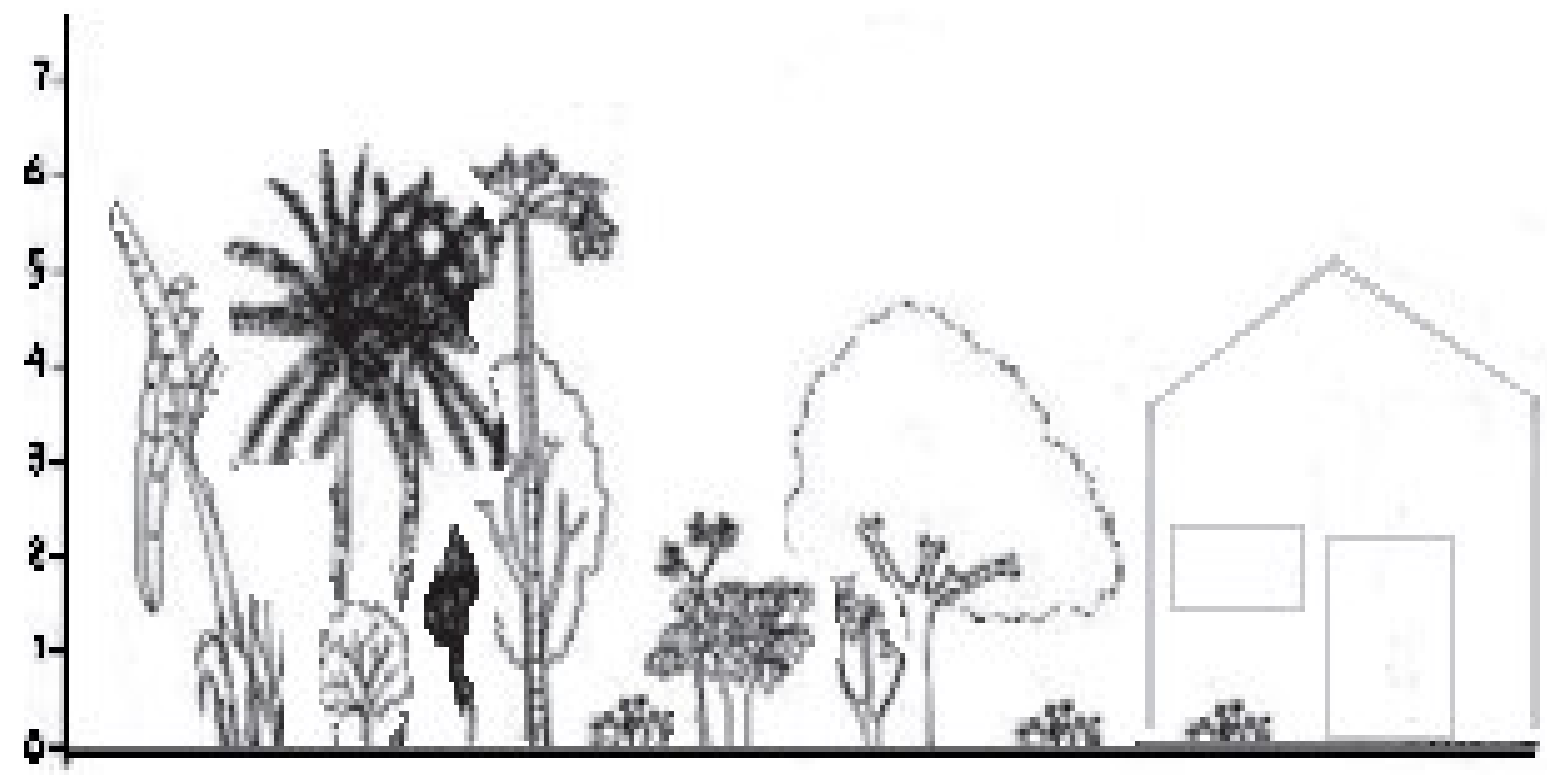




\section{Apêndice D}

Valor dos indicadores socioeconômicos indiretos, índice total e blocos socioeconômicos para as 71 unidades domésticas (comunidades quilombolas de Sapatu, Pedro Cubas e São Pedro, município de Eldorado Paulista, São Paulo). (eletrodomésticos: $\mathrm{um}=0,125$; dois $=0,25$; três $=0,375$ (...) e oito $=1$; escolaridade: analfabetos com valor 0 ; fundamental incompleto com valor 0,2 ; fundamental completo com valor 0,4; médio incompleto com valor 0,6 ; médio completo com valor 0,8 ; e superior incompleto com valor 1 )

Tabela D.1 Sapatu

\begin{tabular}{ccccc}
$\begin{array}{c}\text { Nome fictício } \\
\text { dos } \\
\text { informantes }\end{array}$ & $\begin{array}{c}\text { código da } \\
\text { UD }\end{array}$ & eletrodomésticos & escolaridade & liderança \\
\hline Nio & SAP1 & 0,75 & 0,2 & 0 \\
Ari & SAP2 & 0,5 & 0 & 0 \\
Nedi & SAP3 & 0,25 & 0 & 0 \\
Eno & SAP4 & 0 & 0 & 0 \\
Laudica & SAP5 & 0,5 & 0,2 & 0 \\
Oneida & SAP6 & 0,25 & 0,2 & 0 \\
Ivi & SAP7 & 0,75 & 0 & 0 \\
Nilma & SAP8 & 0,375 & 0 & 0 \\
Ane & SAP9 & 7 & 0,6 & 0 \\
Era & SAP10 & 0,5 & 0,2 & 1 \\
Vavá & SAP11 & 0,375 & 0 & 0 \\
Ilda & SAP12 & 0,75 & 0,6 & 0 \\
Zaí & SAP13 & 0,5 & 0,2 & 1 \\
Danda & SAP14 & 5 & 0,2 & 0 \\
Cira & SAP15 & 0,5 & 0,2 & 0 \\
\hline
\end{tabular}


Continuação da Tabela D.1 Sapatu

\begin{tabular}{|c|c|c|c|c|}
\hline $\begin{array}{l}\text { Nome fictício } \\
\text { dos } \\
\text { informantes }\end{array}$ & $\begin{array}{c}\text { código da } \\
\text { UD }\end{array}$ & eletrodomésticos & escolaridade & liderança \\
\hline Ana & SAP16 & 0 & 0 & 0 \\
\hline Bruna & SAP17 & 0,25 & 0 & 0 \\
\hline Ursula & SAP18 & 5 & 0 & 0 \\
\hline Nio & SAP19 & 1 & 0,2 & 0 \\
\hline Ari & SAP20 & 7 & 0 & 0 \\
\hline Nedi & SAP21 & 0,675 & 0,2 & 0 \\
\hline Eno & SAP22 & 0,675 & 0,2 & 0 \\
\hline Laudica & SAP23 & 0,25 & 0,2 & 0 \\
\hline Oneida & SAP24 & 7 & 0,2 & 0 \\
\hline Ivi & SAP25 & 0,75 & 0,2 & 0 \\
\hline Nilma & SAP26 & 0,5 & 0 & 1 \\
\hline Ane & SAP27 & 0 & 0 & 0 \\
\hline Era & SAP28 & 0,25 & 0,2 & 0 \\
\hline Vavá & SAP29 & 0,25 & 0 & 0 \\
\hline Ilda & SAP30 & 5 & 0,2 & 0 \\
\hline
\end{tabular}


Tabela D.2 Pedro Cubas

\begin{tabular}{|c|c|c|c|c|}
\hline $\begin{array}{c}\text { Nome fictício } \\
\text { dos } \\
\text { informantes }\end{array}$ & $\begin{array}{l}\text { código da } \\
\text { UD }\end{array}$ & eletrodomésticos & escolaridade & liderança \\
\hline Adi & PEC1 & 0,25 & 0 & 0 \\
\hline Ino & PEC2 & 0,375 & 0,2 & 0 \\
\hline Toni & PEC3 & 0,125 & 0,2 & 0 \\
\hline Cida & PEC4 & 0,5 & 0 & 1 \\
\hline Enedina & PEC5 & 0,125 & 0,2 & 0 \\
\hline Miro & PEC6 & 0,25 & 0,2 & 0 \\
\hline Otávia & PEC7 & 0,125 & 0,2 & 0 \\
\hline Tiane & PEC8 & 0 & 0,2 & 0 \\
\hline Iva & PEC9 & 0,75 & 0,8 & 1 \\
\hline Vânia & PEC10 & 0,5 & 0,2 & 0 \\
\hline Liane & PEC11 & 0,5 & 0,2 & 0 \\
\hline Zaíra & PEC12 & 0,25 & 0,2 & 0 \\
\hline Mili & PEC13 & 0 & 0,2 & 0 \\
\hline Rosana & PEC14 & 0,375 & 0 & 0 \\
\hline Nilton & PEC15 & 0,125 & 0 & 0 \\
\hline Edu & PEC16 & 0,25 & 0 & 0 \\
\hline Marta & PEC17 & 0,125 & 0,2 & 0 \\
\hline Aura & PEC18 & 0,25 & 0 & 0 \\
\hline Idê & PEC19 & 0,125 & 1 & 1 \\
\hline Geísa & PEC20 & 0,5 & 0,2 & 0 \\
\hline Niva & PEC21 & 0 & 0,2 & 0 \\
\hline Cris & PEC22 & 0 & 0 & 0 \\
\hline Francisca & PEC23 & 5 & 0 & 0 \\
\hline Bete & PEC24 & 0 & 0 & 0 \\
\hline Sabrina & PEC25 & 0 & 0,2 & 0 \\
\hline Edi & PEC26 & 0 & 0,2 & 0 \\
\hline Virna & PEC27 & 0,25 & 0,8 & 0 \\
\hline
\end{tabular}


Tabela D.3 São Pedro Nome fictício

\begin{tabular}{ccccc}
$\begin{array}{c}\text { dos } \\
\text { informantes }\end{array}$ & $\begin{array}{c}\text { código } \\
\text { da UD }\end{array}$ & eletrodomésticos & escolaridade & liderança \\
\hline Lia e Zico & SP1 & 0,5 & 0 & 0 \\
Vertulina & SP2 & 0 & 0 & 0 \\
Teresa & SP3 & 0,25 & 0,6 & 0 \\
Sandra & SP4 & 0,5 & 0 & 0 \\
Virna & SP5 & 0,5 & 0,6 & 0 \\
Tide & SP6 & 0,25 & 0,2 & 0 \\
Lina & SP7 & 7 & 0,2 & 0 \\
Delina & SP8 & 0,5 & 0 & 0 \\
Cora & SP9 & 0,625 & 0 & 0 \\
Celina & SP10 & 0,75 & 0,2 & 0 \\
Tina & SP11 & 0,25 & 0,2 & 0 \\
Zinha & SP12 & 0,75 & 0,2 & 0 \\
Nice & SP13 & 0,5 & 0,2 & 1 \\
Eni & SP14 & 0,125 & 0,6 & 1 \\
\hline
\end{tabular}




\section{Apêndice $E$}

Nome fictício dos informantes, código da UD, número de etnovariedades distintas

Tabela F.1: Comunidade de Sapatu nome fictício dos código da número de etnovariedades

\begin{tabular}{|c|c|c|}
\hline informantes & UD & distintas \\
\hline Nio & SAP1 & 41 \\
\hline Ari & SAP2 & 20 \\
\hline Nedi & SAP3 & 27 \\
\hline Eno & SAP4 & 38 \\
\hline Laudica & SAP5 & 39 \\
\hline Oneida & SAP6 & 49 \\
\hline Ivi & SAP7 & 82 \\
\hline Nilma & SAP8 & 53 \\
\hline Ane & SAP9 & 21 \\
\hline Era & SAP10 & 117 \\
\hline Vavá & SAP11 & 45 \\
\hline Ilda & SAP12 & 17 \\
\hline Zaí & SAP13 & 45 \\
\hline Danda & SAP14 & 81 \\
\hline Cira & SAP15 & 66 \\
\hline Ana & SAP16 & 24 \\
\hline Bruna & SAP17 & 45 \\
\hline Ursula & SAP18 & 65 \\
\hline Ciana & SAP19 & 16 \\
\hline Gui & SAP20 & 55 \\
\hline Ariane & SAP21 & 35 \\
\hline
\end{tabular}


Continuação da Tabela F.1: Comunidade de Sapatu

\begin{tabular}{ccc}
$\begin{array}{c}\text { Continuação da fictício dos } \\
\text { informantes }\end{array}$ & $\begin{array}{c}\text { código da } \\
\text { UD }\end{array}$ & $\begin{array}{c}\text { número de etnovariedades } \\
\text { distintas }\end{array}$ \\
\hline Nide & SAP22 & 44 \\
Isa & SAP23 & 45 \\
Vani & SAP24 & 27 \\
Lica & SAP25 & 51 \\
Sila & SAP26 & 32 \\
Nina & SAP27 & 22 \\
Noni & SAP28 & 50 \\
Zazá & SAP29 & 46 \\
Luzi & SAP30 & 29
\end{tabular}


Tabela F.2: Comunidade de Pedro Cubas

\begin{tabular}{|c|c|c|}
\hline nome fictício dos & & número de etnovariedades \\
\hline informantes & código da UD & distintas \\
\hline Adi & PEC1 & 14 \\
\hline Ino & PEC2 & 24 \\
\hline Toni & PEC3 & 37 \\
\hline Cida & PEC4 & 35 \\
\hline Enedina & PEC5 & 21 \\
\hline Miro & PEC6 & 13 \\
\hline Otávia & PEC7 & 28 \\
\hline Tiane & PEC8 & 13 \\
\hline Iva & PEC9 & 55 \\
\hline Vânia & PEC10 & 13 \\
\hline Liane & PEC11 & 16 \\
\hline Zaíra & PEC12 & 23 \\
\hline Mili & PEC13 & 54 \\
\hline Rosana & PEC14 & 57 \\
\hline Nilton & PEC15 & 21 \\
\hline Edu & PEC16 & 26 \\
\hline Marta & PEC17 & 38 \\
\hline Aura & PEC18 & 47 \\
\hline Idê & PEC19 & 68 \\
\hline Geísa & PEC20 & 59 \\
\hline Niva & PEC21 & 17 \\
\hline Cris & PEC22 & 15 \\
\hline Francisca & PEC23 & 77 \\
\hline Bete & PEC24 & 12 \\
\hline Sabrina & PEC25 & 12 \\
\hline Edi & PEC26 & 38 \\
\hline Virna & PEC27 & 51 \\
\hline
\end{tabular}


Tabela F.3: Comunidade de São Pedro

\begin{tabular}{ccc}
$\begin{array}{c}\text { Tabela F.3: Comunidade de São Pedro } \\
\text { nome fictício dos } \\
\text { informantes }\end{array}$ & $\begin{array}{c}\text { código da } \\
\text { UD }\end{array}$ & $\begin{array}{c}\text { número de etnovariedades } \\
\text { distintas }\end{array}$ \\
\hline Lia e Zico & SP1 & 43 \\
Vertulina & SP2 & 22 \\
Teresa & SP3 & 6 \\
Sandra & SP4 & 64 \\
Virna & SP5 & 79 \\
Tide & SP6 & 63 \\
Lina & SP7 & 32 \\
Delina & SP8 & 80 \\
Cora & SP9 & 38 \\
Celina & SP10 & 46 \\
Tina & SP11 & 65 \\
Zinha & SP12 & 69 \\
Nice & SP13 & 46 \\
Eni & SP14 & 38
\end{tabular}




\section{Apêndice F}

Etnovariedades parcial ou totalmente identificadas presentes nos jardins quintal das comunidades quilombolas de Sapatu, São Pedro e Pedro Cubas, município de Eldorado Paulista, SP. (SAP: Sapatu; PEC: Pedro Cubas; SP: São Pedro; Oc: ocorrência; n: número de unidades domésticas visitadas por comunidade; Fr.: frequencia relativa $(n=71)$; Uso: $\mathbf{1}=$ alimentação; $2=$ medicinal; 3 = ornamental; $\mathbf{4}$ = simbólico-afetiva; $\mathbf{5}=$ outros)

\begin{tabular}{|c|c|c|c|c|c|c|}
\hline família & espécie biológica & denominação local & $\begin{array}{c}\text { SAP } \\
(\mathrm{n}=30)\end{array}$ & $\begin{array}{c}\text { PEC } \\
(\mathrm{n}=27)\end{array}$ & $\begin{array}{c}\text { SP } \\
(n=14)\end{array}$ & $\begin{array}{c}\text { total } \\
(n=71)\end{array}$ \\
\hline
\end{tabular}

\section{Acanthaceae}

Justicia brandegeana Wash \& L.B.Sm. Eranthemum pulchellum Andrews

Thunbergia sp.

camarão vermelho

cerca viva

não denominada

\section{Oc Oc Oc Oc Fr. Uso}

\section{Agavaceae}

Agave americana L.

Agave sp.

coqueirinho

pita

$\begin{array}{ll}0 & 0 \\ 0 & 0 \\ 1 & 0\end{array}$

0,01

$0,01 \quad 3,5$

não denominada

1

1
1
0

5 3

Alismataceae

$\begin{array}{lllllllll}\text { Echinodorus sp. } & \text { chapéu de couro } & 2 & 0 & 1 & 3 & 0,04 & 2,5\end{array}$

\section{Alliaceae}

\begin{tabular}{rcccccccc} 
Allium cepa L. & cebola & 3 & 1 & 2 & 6 & 0,08 & 1 \\
Allium schoenoprasum L. & cebolinha & 15 & 7 & 3 & 25 & 0,35 & 1 \\
\hline
\end{tabular}


Continuação: Etnovariedades parcial ou totalmente identificadas presentes nos jardins quintal das comunidades quilombolas de Sapatu, São Pedro e Pedro Cubas, município de Eldorado Paulista, SP. (SAP: Sapatu; PEC: Pedro Cubas; SP: São Pedro; Oc: ocorrência; $\mathbf{n}$ : número de unidades domésticas visitadas por comunidade; Fr.: frequencia relativa ( $\mathrm{n=71}$ ); Uso: 1 = alimentação; 2 = medicinal; $\mathbf{3}=$ ornamental; $\mathbf{4}$ = simbólico-afetiva; $\mathbf{5}$ = outros)

\begin{tabular}{llcccc}
\hline família & & SAP & PEC & SP & total \\
& espécie biológica & denominação local & $(n=30)$ & $(n=27)$ & $(n=14)$ \\
$(n=71)$
\end{tabular}

\section{Amaranthaceae}

Alternanthera brasiliana (L.) Kuntze Chenopodium ambrosioides L.

Chenopodium sp. Iresine herbstii Hook Celosia argentea L. sem identificação sem identificação sem identificação sem identificação

\section{Amaryllidaceae}

Hippeastrum puniceum (Lam) Voos

Crinum cf. erubescens Aiton

\section{Anacardiaceae}

Anacardium occidentale L. Mangifera indica $\mathrm{L}$. Schinus sp. ampicilina (antibiótica, cibalena, anador)

erva de Santa Maria mentruz sangue de boi (vermelhão) suspiro não denominada não denominada não denominada não denominada

\section{Oc Oc Oc $\quad$ Oc $\quad$ Fr. Uso}

açucena

açucena

$\begin{array}{lllcll}3 & 3 & 4 & 10 & 0,14 & 3 \\ 2 & 1 & 0 & 3 & 0,04 & 3\end{array}$

\begin{tabular}{rrrrrrrr} 
Anacardiaceae & & & & 3 & 0,04 & 1 \\
Anacardium occidentale L. & caju & 1 & 1 & 1 & 28 & 0,39 & 1 \\
Mangifera indica L. & manga & 21 & 4 & 3 & 28 & 0,01 & 2,4 \\
Schinus sp. & rueira & 0 & 1 & 0 & 1 & 0,01 \\
\hline
\end{tabular}


Continuação: Etnovariedades parcial ou totalmente identificadas presentes nos jardins quintal das comunidades quilombolas de Sapatu, São Pedro e Pedro Cubas, município de Eldorado Paulista, SP. (SAP: Sapatu; PEC: Pedro Cubas; SP: São Pedro; Oc: ocorrência; $\mathbf{n}$ : número de unidades domésticas visitadas por comunidade; Fr.: frequencia relativa ( $\mathrm{n=71})$; Uso: 1 = alimentação; 2 = medicinal; $\mathbf{3}=$ ornamental; $\mathbf{4}$ = simbólico-afetiva; $\mathbf{5}=$ outros)

\begin{tabular}{|c|c|c|c|c|c|c|}
\hline família & espécie biológica & denominação local & $\begin{array}{l}\text { SAP } \\
(\mathrm{n}=30)\end{array}$ & $\begin{array}{c}\text { PEC } \\
(\mathrm{n}=27)\end{array}$ & $\begin{array}{c}\text { SP } \\
(n=14)\end{array}$ & $\begin{array}{l}\text { total } \\
(\mathrm{n}=71)\end{array}$ \\
\hline
\end{tabular}

Annonaceae

$\begin{array}{rc}\text { Annona sp. } & \text { ata } \\ \text { Annona sp. } & \text { ata maior } \\ \text { Annona cf cacans Warm. } & \text { conde } \\ \text { Annona sp. } & \text { graviola } \\ \text { Spondias purpurea L. } & \text { siriguela }\end{array}$

\section{Apiaceae}

\begin{tabular}{rccccccc} 
Daucus carota L. & cenoura & 2 & 1 & 0 & 3 & 0,04 & 04 \\
Coriandrum sativum L. & coentro & 4 & 4 & 3 & 11 & 0,15 & 1 \\
Pimpinella anisum L. & erva doce & 10 & 1 & 4 & 15 & 0,21 & 1 \\
Arracacia xanthorrhiza Bancr & mandioquinha & 0 & 0 & 1 & 1 & 0,01 & 1 \\
Ammi cf majus L. & não denominada & 1 & 0 & 0 & 1 & 0,01 & 2 \\
Petroselinum crispum (Mill.) Mansf. & salsinha & 6 & 2 & 2 & 10 & 0,14 & 1 \\
& & & & & & & \\
cynaceae & & & & & & \\
Catharanthus roseus (L.) G. Don & flor de noiva & 8 & 1 & 4 & 13 & 0,18 & 3 \\
Allamanda schotti Pohl & fogueteiro amarelo & 3 & 0 & 0 & 3 & 0,04 & 3,5 \\
\hline
\end{tabular}


Continuação: Etnovariedades parcial ou totalmente identificadas presentes nos jardins quintal das comunidades quilombolas de Sapatu, São Pedro e Pedro Cubas, município de Eldorado Paulista, SP. (SAP: Sapatu; PEC: Pedro Cubas; SP: São Pedro; Oc: ocorrência; $\mathbf{n}$ : número de unidades domésticas visitadas por comunidade; Fr.: frequencia relativa ( $\mathrm{n}=71)$; Uso: 1 = alimentação; 2 = medicinal; $\mathbf{3}=$ ornamental; $\mathbf{4}$ = simbólico-afetiva; $\mathbf{5}$ = outros)

\begin{tabular}{llcccc}
\hline família & & SAP & PEC & SP & total \\
& espécie biológica & denominação local & $(n=30)$ & $(n=27)$ & $(n=14)$ \\
$(n=71)$
\end{tabular}

\section{Araceae}

Anthurium andraeanum Linden Syngoniums sp. Dieffembachia $s p$ Dieffenbachia amoena Hort. ex Gentil Colocasia esculenta (L.) Schott Philodendron cf pinnatifidum Schott Colocasia esculenta (L.) Schott Anthurium sp

Caladium cf lindenii (André) Madison Caladium sp. Philodendron sp. Sigonium $s p$. Syndapsus sp. Philodendron $s p$. Caladium cf bicolor Vent Xanthosoma sp

Syngonium angustissimum Schott Xanthosoma cf blandum Schott sem identificação

\section{anturio}

comigo ninguém pode

comigo ninguém pode

comigo ninguém pode inhame

mandimbé

mangarito (inhame roxinho)

não denominada

não denominada

não denominada

não denominada

não denominada

não denominada

$$
\text { pacova }
$$

taiá de enfeite (cará de viado)

taiá preto, taiá jambo

trepadeira

taiá, taioba

não denominada

\section{Oc Oc Oc Oc $\quad$ Fr. Uso}

$\begin{array}{cccccc}1 & 0 & 0 & 1 & 0,01 & 3 \\ 8 & 2 & 9 & 19 & 0,27 & 3 \\ 0 & 1 & 6 & 7 & 0,10 & 1,4 \\ 1 & 2 & 0 & 3 & 0,04 & 3 \\ 2 & 3 & 6 & 11 & 0,15 & 1 \\ 0 & 6 & 3 & 9 & 0,13 & 1 \\ 3 & 13 & 2 & 18 & 0,25 & 1 \\ 2 & 0 & 0 & 2 & 0,03 & 2 \\ 0 & 0 & 1 & 1 & 0,01 & 2 \\ 1 & 0 & 0 & 1 & 0,01 & 2 \\ 1 & 0 & 0 & 1 & 0,01 & 2 \\ 3 & 0 & 0 & 3 & 0,04 & 2 \\ 1 & 0 & 0 & 1 & 0,01 & 2 \\ 1 & 5 & 2 & 8 & 0,11 & 5 \\ 2 & 4 & 8 & 14 & 0,20 & 3 \\ 1 & 2 & 0 & 3 & 0,04 & 1 \\ 2 & 0 & 2 & 4 & 0,06 & 1 \\ 8 & 9 & 5 & 22 & 0,31 & 3 \\ 1 & 0 & 0 & 1 & 0,01 & 3\end{array}$


Continuação: Etnovariedades parcial ou totalmente identificadas presentes nos jardins quintal das comunidades quilombolas de Sapatu, São Pedro e Pedro Cubas, município de Eldorado Paulista, SP. (SAP: Sapatu; PEC: Pedro Cubas; SP: São Pedro; Oc: ocorrência; $\mathbf{n}$ : número de unidades domésticas visitadas por comunidade; Fr.: frequencia relativa ( $\mathrm{n=71}$ ); Uso: 1 = alimentação; 2 = medicinal; $\mathbf{3}$ = ornamental; $\mathbf{4}$ = simbólico-afetiva; $\mathbf{5}=$ outros)

\begin{tabular}{|c|c|c|c|c|c|c|c|}
\hline espécie biológica & denominação local & $\begin{array}{c}\text { SAP } \\
(\mathrm{n}=30)\end{array}$ & $\begin{array}{c}\text { PEC } \\
(\mathrm{n}=27)\end{array}$ & $\begin{array}{c}\text { SP } \\
(n=14)\end{array}$ & $\begin{array}{c}\text { total } \\
(\mathrm{n}=71)\end{array}$ & & \\
\hline & & Oc & Oc & Oc & Oc & Fr. & Uso \\
\hline \multicolumn{8}{|l|}{ Araceae } \\
\hline sem identificação & não denominada & 1 & 0 & 0 & 1 & 0,01 & 3 \\
\hline sem identificação & não denominada & 0 & 1 & 0 & 1 & 0,01 & 3 \\
\hline sem identificação & não denominada & 0 & 1 & 0 & 1 & 0,01 & 3 \\
\hline sem identificação & não denominada & 1 & 0 & 0 & 1 & 0,01 & 3 \\
\hline sem identificação & não denominada & 0 & 0 & 1 & 1 & 0,01 & 3 \\
\hline \multicolumn{8}{|l|}{ Araliaceae } \\
\hline Schefflera arboricola (Hayata) Merr. & $\begin{array}{c}\text { pau da sorte, fortuna, salva } \\
\text { vidas }\end{array}$ & 6 & 6 & 1 & 13 & 0,18 & 3,4 \\
\hline \multicolumn{8}{|l|}{ Araucariaceae } \\
\hline Araucaria angustifolia (Bertol.) Kuntze & araucária & 1 & 0 & 0 & 1 & 0,01 & 3 \\
\hline \multicolumn{8}{|l|}{ Arecaceae } \\
\hline Cocos nucifera L. & $\begin{array}{l}\text { côco da bahia } \\
\text { coroa de judeu (coroa de }\end{array}$ & 3 & 1 & 0 & 4 & 0,06 & 1,3 \\
\hline Licuala sp. & cristo) & 1 & 2 & 1 & 4 & 0,06 & 3 \\
\hline Dypsis sp & não denominada & 1 & 0 & 0 & 1 & 0,01 & 3 \\
\hline
\end{tabular}


Continuação: Etnovariedades parcial ou totalmente identificadas presentes nos jardins quintal das comunidades quilombolas de Sapatu, São Pedro e Pedro Cubas, município de Eldorado Paulista, SP. (SAP: Sapatu; PEC: Pedro Cubas; SP: São Pedro; Oc: ocorrência; $\mathbf{n}$ : número de unidades domésticas visitadas por comunidade; Fr.: frequencia relativa ( $\mathrm{n}=71)$; Uso: 1 = alimentação; 2 = medicinal; $\mathbf{3}$ = ornamental; $\mathbf{4}$ = simbólico-afetiva; $\mathbf{5}$ = outros)

\begin{tabular}{|c|c|c|c|c|c|c|c|}
\hline espécie biológica & denominação local & $\begin{array}{c}\text { SAP } \\
(\mathrm{n}=30)\end{array}$ & $\begin{array}{c}\text { PEC } \\
(\mathrm{n}=27)\end{array}$ & $\begin{array}{c}\text { SP } \\
(n=14)\end{array}$ & $\begin{array}{c}\text { total } \\
(\mathrm{n}=71)\end{array}$ & & \\
\hline & & Oc & Oc & Oc & Oc & Fr. & Uso \\
\hline \multicolumn{8}{|l|}{ Arecaceae } \\
\hline Roystonea oleracea (Jacq.) O.F. Cook & não denominada & 1 & 0 & 0 & 1 & 0,01 & 3 \\
\hline Euterpe oleracea Mart. & palmeira açaí & 0 & 2 & 0 & 2 & 0,03 & 1,3 \\
\hline Syagrus romanzoffiana (Cham.) Glassman & palmeira jaruvá & 16 & 7 & 3 & 26 & 0,37 & 1,3 \\
\hline Euterpe edulis Mart. & palmeira jussara & 21 & 11 & 7 & 39 & 0,55 & $1,3,5$ \\
\hline $\begin{array}{r}\text { Bactris gasipes Kunth } \\
\text { Archontophoenix alexandrae (F. Muell.) H. }\end{array}$ & palmeira pupunha & 7 & 8 & 4 & 19 & 0,27 & $1,3,5$ \\
\hline $\begin{array}{r}\text { Wendl. \& Drude } \\
\text { Archontophoenix cunninghamiana H. Wendl. }\end{array}$ & palmeira real & 7 & 8 & 0 & 15 & 0,21 & $1,3,5$ \\
\hline \& Drude & palmeira real & 0 & 1 & 0 & 1 & 0,01 & 1,3 \\
\hline Bactris setosa Mart. & tuncum & 0 & 2 & 0 & 2 & 0,03 & 1,5 \\
\hline sem identificação & palmeira do mato & 0 & 0 & 1 & 1 & 0,01 & 3 \\
\hline sem identificação & não denominada & 0 & 0 & 1 & 1 & 0,01 & 3 \\
\hline \multicolumn{8}{|l|}{ Asteraceae } \\
\hline Lactuca sativa L. & alface & 6 & 3 & 1 & 10 & 0,14 & 1 \\
\hline Cichorium intybus $\mathrm{L}$. & almeirão & 4 & 8 & 1 & 13 & 0,18 & 1 \\
\hline Achillea millefolium $\mathrm{L}$. & camomila & 2 & 1 & 1 & 4 & 0,06 & 1 \\
\hline Cichorium endivia $\mathrm{L}$. & chicória & 1 & 0 & 0 & 1 & 0,01 & 1 \\
\hline Bidens sulphurea (Cav.) Sch. Bip. & cravo (amor de chico) & 3 & 0 & 3 & 6 & 0,08 & 3 \\
\hline
\end{tabular}


Continuação: Etnovariedades parcial ou totalmente identificadas presentes nos jardins quintal das comunidades quilombolas de Sapatu, São Pedro e Pedro Cubas, município de Eldorado Paulista, SP. (SAP: Sapatu; PEC: Pedro Cubas; SP: São Pedro; Oc: ocorrência; $\mathbf{n}$ : número de unidades domésticas visitadas por comunidade; Fr.: frequencia relativa ( $\mathrm{n}=71)$; Uso: 1 = alimentação; 2 = medicinal; $\mathbf{3}$ = ornamental; $\mathbf{4}$ = simbólico-afetiva; $\mathbf{5}$ = outros)

\begin{tabular}{|c|c|c|c|c|c|c|c|c|}
\hline família & espécie biológica & denominação local & $\begin{array}{c}\text { SAP } \\
(\mathrm{n}=30)\end{array}$ & $\begin{array}{c}\text { PEC } \\
(\mathrm{n}=27)\end{array}$ & $\begin{array}{c}\mathbf{S P} \\
(\mathrm{n}=14)\end{array}$ & $\begin{array}{c}\text { total } \\
(\mathrm{n}=71)\end{array}$ & & \\
\hline & & & Oc & Oc & Oc & Oc & Fr. & Uso \\
\hline \multicolumn{9}{|c|}{ Asteraceae } \\
\hline & Zinnia elegans Jacq. & cravo (maricão, vege) & 9 & 3 & 5 & 17 & 0,24 & 3 \\
\hline & Dahlia sp. & dália & 2 & 0 & 0 & 2 & 0,03 & 3 \\
\hline & Vernonia condensata Baker & estomalina & 5 & 0 & 1 & 6 & 0,08 & 2 \\
\hline & Helianthus sp. & flor de amazona & 7 & 8 & 3 & 18 & 0,25 & 2 \\
\hline & Helianthus annuus L. & girassol & 0 & 1 & 0 & 1 & 0,01 & 3 \\
\hline & sem identificação & turmalina & 3 & 0 & 0 & 3 & 0,04 & 3 \\
\hline & sem identificação & não denominada & 1 & 0 & 0 & 1 & 0,01 & 3 \\
\hline \multicolumn{9}{|c|}{ Balsaminaceae } \\
\hline & Impatiens wallerana Hook. $\mathrm{f}$. & maria sem vergonha (beijo) & 6 & 0 & 4 & 10 & 0,14 & 3 \\
\hline & Impatiens balsamina L. & não denominada & 1 & 0 & 0 & 1 & 0,01 & 3 \\
\hline \multicolumn{9}{|c|}{ Begoniaceae } \\
\hline & Begonia sp. & begônia & 1 & 0 & 0 & 1 & 0,01 & 3 \\
\hline & Begonia sp. & não denominada & 3 & 0 & 0 & 3 & 0,04 & 3 \\
\hline & Begonia setosa Klotzsch & sabugueira & 1 & 0 & 0 & 1 & 0,01 & 3 \\
\hline
\end{tabular}


Continuação: Etnovariedades parcial ou totalmente identificadas presentes nos jardins quintal das comunidades quilombolas de Sapatu, São Pedro e Pedro Cubas, município de Eldorado Paulista, SP. (SAP: Sapatu; PEC: Pedro Cubas; SP: São Pedro; Oc: ocorrência; $\mathbf{n}$ : número de unidades domésticas visitadas por comunidade; Fr.: frequencia relativa ( $\mathrm{n}=71)$; Uso: 1 = alimentação; 2 = medicinal; $\mathbf{3}$ = ornamental; $\mathbf{4}$ = simbólico-afetiva; $\mathbf{5}$ = outros)

\begin{tabular}{|c|c|c|c|c|c|c|c|}
\hline espécie biológica & denominação local & $\begin{array}{c}\text { SAP } \\
(n=30)\end{array}$ & $\begin{array}{c}\text { PEC } \\
(\mathrm{n}=27)\end{array}$ & $\begin{array}{c}\text { SP } \\
(n=14)\end{array}$ & $\begin{array}{c}\text { total } \\
(\mathrm{n}=71)\end{array}$ & & \\
\hline & & Oc & Oc & Oc & Oc & Fr. & Uso \\
\hline \multicolumn{8}{|l|}{ Bixaceae } \\
\hline Bixa orellana L. & coloral (urucum) & 6 & 12 & 2 & 20 & 0,28 & 1,5 \\
\hline \multicolumn{8}{|l|}{ Bombacaceae } \\
\hline Pachira cf aquatica Aubl. & castanheira & 9 & 4 & 7 & 20 & 0,28 & 1,5 \\
\hline \multicolumn{8}{|l|}{ Brassicaceae (Cruciferae) } \\
\hline Rorippa nasturtium-aquaticum (L.) Hayek & agrião & 1 & 0 & 0 & 1 & 0,01 & 1 \\
\hline Brassica oleracea var. italica & brócolis & 2 & 0 & 1 & 3 & 0,04 & 1 \\
\hline Brassica sp. & couve & 15 & 6 & 5 & 26 & 0,37 & 1 \\
\hline Brassica sp. & couve chinesa & 1 & 0 & 0 & 1 & 0,01 & 1 \\
\hline Brassica sp. & couve preta & 1 & 0 & 1 & 2 & 0,03 & 1 \\
\hline Brassica sp. & couve-flor & 2 & 0 & 0 & 2 & 0,03 & 1 \\
\hline Sinapis alba L. & mostarda & 2 & 0 & 0 & 2 & 0,03 & 1 \\
\hline Eruca sativa Mill. & rúcula & 4 & 0 & 0 & 4 & 0,06 & 1 \\
\hline \multicolumn{8}{|l|}{ Bromeliaceae } \\
\hline Ananas bracteatus (Lindl.) Schult. \& Schult. f. & abacaxi & 5 & 11 & 8 & 24 & 0,34 & 1 \\
\hline Ananas cf comosus (L.) Merr. (L.) Merr. & abacaxi naná & 7 & 7 & 4 & 18 & 0,25 & 1 \\
\hline Ananas sp. & abacaxi naná & 0 & 1 & 0 & 1 & 0,01 & 1 \\
\hline
\end{tabular}


Continuação: Etnovariedades parcial ou totalmente identificadas presentes nos jardins quintal das comunidades quilombolas de Sapatu, São Pedro e Pedro Cubas, município de Eldorado Paulista, SP. (SAP: Sapatu; PEC: Pedro Cubas; SP: São Pedro; Oc: ocorrência; $\mathbf{n}$ : número de unidades domésticas visitadas por comunidade; Fr.: frequencia relativa ( $\mathrm{n}=71)$; Uso: 1 = alimentação; 2 = medicinal; $\mathbf{3}$ = ornamental; $\mathbf{4}$ = simbólico-afetiva; $\mathbf{5}$ = outros)

\begin{tabular}{|c|c|c|c|c|c|c|c|}
\hline espécie biológica & denominação local & $\begin{array}{c}\text { SAP } \\
(n=30)\end{array}$ & $\begin{array}{c}\text { PEC } \\
(\mathrm{n}=27)\end{array}$ & $\begin{array}{c}\mathbf{S P} \\
(n=14)\end{array}$ & $\begin{array}{c}\text { total } \\
(\mathrm{n}=71)\end{array}$ & & \\
\hline & & Oc & Oc & Oc & Oc & Fr. & Uso \\
\hline \multicolumn{8}{|l|}{ Bromeliaceae } \\
\hline Tillandsia sp & bromélia & 3 & 1 & 0 & 4 & 0,06 & 3 \\
\hline Vriesea carinata Wawra & não denominada & 0 & 1 & 0 & 1 & 0,01 & 3 \\
\hline sem identificação & caetê do mato & 1 & 0 & 0 & 1 & 0,01 & 3 \\
\hline sem identificação & caraguatá & 1 & 2 & 3 & 6 & 0,08 & 3 \\
\hline sem identificação & bromélia & 0 & 1 & 1 & 2 & 0,03 & 3 \\
\hline \multicolumn{8}{|l|}{ Cactaceae } \\
\hline Nopalea sp. & arombeva de enfeite & 0 & 0 & 1 & 1 & 0,01 & 3 \\
\hline Schlumbergera truncata Moran & flor de maio & 4 & 0 & 0 & 4 & 0,06 & 3 \\
\hline Rhipsalis baccifera (J.S. Muell.) & não denominada & 1 & 0 & 0 & 1 & 0,01 & 3 \\
\hline Opuntia sp & palma norte (cactos) & 3 & 0 & 2 & 5 & 0,07 & 3 \\
\hline sem identificação & açadi & 0 & 1 & 0 & 1 & 0,01 & 3 \\
\hline \multicolumn{8}{|l|}{ Campanulaceae } \\
\hline Laurentia sp. & estrelinha & 1 & 0 & 0 & 1 & 0,01 & 3 \\
\hline \multicolumn{8}{|l|}{ Cannaceae } \\
\hline Canna indica $\mathrm{L}$. & biri (caetê) & 3 & 5 & 8 & 16 & 0,23 & 3 \\
\hline Canna sp. & napoleão & 0 & 2 & 1 & 3 & 0,04 & 3 \\
\hline
\end{tabular}


Continuação: Etnovariedades parcial ou totalmente identificadas presentes nos jardins quintal das comunidades quilombolas de Sapatu, São Pedro e Pedro Cubas, município de Eldorado Paulista, SP. (SAP: Sapatu; PEC: Pedro Cubas; SP: São Pedro; Oc: ocorrência; $\mathbf{n}$ : número de unidades domésticas visitadas por comunidade; Fr.: frequencia relativa ( $\mathrm{n}=71)$; Uso: $\mathbf{1}=$ alimentação; 2 = medicinal; $\mathbf{3}$ = ornamental; 4 = simbólico-afetiva; 5 = outros)

\begin{tabular}{|c|c|c|c|c|c|c|c|c|}
\hline família & espécie biológica & denominação local & $\begin{array}{c}\text { SAP } \\
(\mathrm{n}=30)\end{array}$ & $\begin{array}{c}\text { PEC } \\
(\mathrm{n}=27)\end{array}$ & $\begin{array}{c}\text { SP } \\
(n=14)\end{array}$ & $\begin{array}{c}\text { total } \\
(n=71)\end{array}$ & & \\
\hline & & & Oc & Oc & Oc & Oc & Fr. & Uso \\
\hline \multicolumn{9}{|c|}{ Cannaceae } \\
\hline & Canna limbata Roscoe & suspiro & 1 & 1 & 0 & 2 & 0,03 & 3 \\
\hline \multicolumn{9}{|c|}{ Caprifoliaceae } \\
\hline & Sambucus nigra L. & sabugueiro (salva vidas) & 3 & 7 & 0 & 10 & 0,14 & 2 \\
\hline \multicolumn{9}{|c|}{ Caricaceae } \\
\hline & Carica sp. & mamão & 15 & 21 & 12 & 48 & 0,68 & 1 \\
\hline \multicolumn{9}{|c|}{ Cecropiaceae } \\
\hline & Cecropia hololeuca Miq. & embaúva & 7 & 7 & 1 & 15 & 0,21 & 3,5 \\
\hline \multicolumn{9}{|c|}{ Chenopodiaceae } \\
\hline & Beta vulgaris $\mathrm{L}$. & beterraba & 1 & 0 & 1 & 2 & 0,03 & 1 \\
\hline \multicolumn{9}{|c|}{ Combretaceae } \\
\hline & Terminalia catappa L. & $\begin{array}{l}\text { sombreiro (chapéu de sol } \\
\text { chapéu de couro) }\end{array}$ & 2 & 0 & 8 & 10 & 0,14 & 3,5 \\
\hline
\end{tabular}


Continuação: Etnovariedades parcial ou totalmente identificadas presentes nos jardins quintal das comunidades quilombolas de Sapatu, São Pedro e Pedro Cubas, município de Eldorado Paulista, SP. (SAP: Sapatu; PEC: Pedro Cubas; SP: São Pedro; Oc: ocorrência; $\mathbf{n}$ : número de unidades domésticas visitadas por comunidade; Fr.: frequencia relativa ( $\mathrm{n}=71)$; Uso: 1 = alimentação; 2 = medicinal; $\mathbf{3}$ = ornamental; $\mathbf{4}$ = simbólico-afetiva; $\mathbf{5}$ = outros)

\begin{tabular}{|c|c|c|c|c|c|c|}
\hline família & espécie biológica & denominação local & $\begin{array}{c}\text { SAP } \\
(\mathrm{n}=30)\end{array}$ & $\begin{array}{c}\text { PEC } \\
(\mathrm{n}=27)\end{array}$ & $\begin{array}{c}\mathbf{S P} \\
(\mathrm{n}=14)\end{array}$ & $\begin{array}{c}\text { total } \\
(\mathrm{n}=71)\end{array}$ \\
\hline
\end{tabular}

Commelinaceae

$\begin{array}{rcccccccc}\text { Comelina cf monticola Seub } & \text { teporaba (erva de São João) } & 2 & 0 & 2 & 4 & 0,06 & 2 \\ \text { Commelina sp } & \text { dipirona } & 0 & 1 & 0 & 1 & 0,01 & 2 \\ \text { Callisia cf repens (Jacq.) L. } & \text { rasteira } & 2 & 0 & 2 & 4 & 0,06 & 3\end{array}$

\section{Convolvulaceae}

$\begin{array}{lccccccc}\text { Ipomoea batatas (L.) Lam. } & \text { batata doce branca } & 1 & 3 & 0 & 4 & 0,06 & 1 \\ \text { Ipomoea batatas (L.) Lam. } & \text { batata doce roxa } & 6 & 4 & 1 & 11 & 0,15 & 1\end{array}$

\section{Crassulaceae}

$\begin{array}{rccccccc}\text { Kalanchoe blossfeldiana Poelln. } & \text { erva fortuna } & 2 & 1 & 0 & 3 & 0,04 & 2,3 \\ \text { Kalanchoe pinnata (Lam.) Pers. } & \text { fortuna } & 2 & 0 & 0 & 2 & 0,03 & 2,3 \\ \text { Echeveria sp } & \text { não denominada } & 0 & 0 & 1 & 1 & 0,01 & 3 \\ \text { fedtschenkoi Raym.-Hamet \& H. } & \text { não denominada } & 0 & 0 & 1 & 1 & 0,01 & 3 \\ \text { Perrier } & \text { não denominada } & 2 & 0 & 0 & 2 & 0,03 & 3 \\ \text { Kalanchoe } s p . & \text { não denominada } & 1 & 0 & 0 & 1 & 0,01 & 3 \\ \text { Kalanchoe } s p . & \text { não denominada } & 1 & 0 & 0 & 1 & 0,01 & 3 \\ \text { Kalanchoe sp. } & \text { não denominada } & 0 & 0 & 1 & 1 & 0,01 & 3 \\ \text { Sedum } s p . & \text { não denominada } & 0 & 0 & 2 & 2 & 0,03 & 3\end{array}$


Continuação: Etnovariedades parcial ou totalmente identificadas presentes nos jardins quintal das comunidades quilombolas de Sapatu, São Pedro e Pedro Cubas, município de Eldorado Paulista, SP. (SAP: Sapatu; PEC: Pedro Cubas; SP: São Pedro; Oc: ocorrência; $\mathbf{n}$ : número de unidades domésticas visitadas por comunidade; Fr.: frequencia relativa $(\mathbf{n}=71)$; Uso: $\mathbf{1}=$ alimentação; $\mathbf{2}=$ medicinal; $\mathbf{3}$ = ornamental; 4 = simbólico-afetiva; 5 = outros)

\begin{tabular}{|c|c|c|c|c|c|c|c|c|}
\hline família & espécie biológica & denominação local & $\begin{array}{c}\text { SAP } \\
(\mathrm{n}=30)\end{array}$ & $\begin{array}{c}\text { PEC } \\
(\mathrm{n}=27)\end{array}$ & $\begin{array}{c}\mathbf{S P} \\
(n=14)\end{array}$ & $\begin{array}{c}\text { total } \\
(\mathrm{n}=71)\end{array}$ & & \\
\hline & & & Oc & Oc & Oc & Oc & Fr. & Uso \\
\hline \multicolumn{9}{|c|}{ Cucurbitaceae } \\
\hline & Luffa cylindrica M. Roem. & bucha & 2 & 1 & 0 & 3 & 0,04 & 5 \\
\hline & Sechium edule Sw. & chuchu & 11 & 8 & 5 & 24 & 0,34 & 1 \\
\hline & Momordica sp. & melão & 2 & 0 & 0 & 2 & 0,03 & 1 \\
\hline & Curcubita sp. & abóbora caipira & 5 & 3 & 1 & 9 & 0,13 & 1 \\
\hline & Curcubita sp. & abobora grande & 1 & 4 & 0 & 5 & 0,07 & 1 \\
\hline & Curcubita sp. & abóbora menina & 0 & 1 & 0 & 1 & 0,01 & 1 \\
\hline & Curcubita sp. & abobora pequena & 1 & 0 & 0 & 1 & 0,01 & 1 \\
\hline & Curcubita sp. & abobrinha & 1 & 0 & 0 & 1 & 0,01 & 1 \\
\hline & Cucumis sativus $\mathrm{L}$. & pepino & 0 & 1 & 1 & 2 & 0,03 & 1 \\
\hline \multicolumn{9}{|c|}{ Cyperaceae } \\
\hline & sem identificação & não denominada & 1 & 0 & 0 & 1 & 0,01 & 1 \\
\hline \multicolumn{9}{|c|}{ Davalliaceae } \\
\hline & Davallia fejeensis Hook. & renda portuguesa & 1 & 0 & 0 & 1 & 0,01 & 3 \\
\hline \multicolumn{9}{|c|}{ Dioscoreaceae } \\
\hline & Dioscorea sp. & cará & 1 & 1 & 2 & 4 & 0,06 & 1 \\
\hline & Dioscorea sp. & cará aipim & 1 & 0 & 2 & 3 & 0,04 & 1 \\
\hline
\end{tabular}


Continuação: Etnovariedades parcial ou totalmente identificadas presentes nos jardins quintal das comunidades quilombolas de Sapatu, São Pedro e Pedro Cubas, município de Eldorado Paulista, SP. (SAP: Sapatu; PEC: Pedro Cubas; SP: São Pedro; Oc: ocorrência; $\mathbf{n}$ : número de unidades domésticas visitadas por comunidade; Fr.: frequencia relativa ( $\mathrm{n}=71)$; Uso: 1 = alimentação; 2 = medicinal; $\mathbf{3}$ = ornamental; $\mathbf{4}$ = simbólico-afetiva; $\mathbf{5}$ = outros)

\begin{tabular}{|c|c|c|c|c|c|c|}
\hline família & espécie biológica & denominação local & $\begin{array}{c}\text { SAP } \\
(\mathrm{n}=30)\end{array}$ & $\begin{array}{c}\text { PEC } \\
(\mathrm{n}=27)\end{array}$ & $\begin{array}{c}\mathbf{S P} \\
(\mathrm{n}=14)\end{array}$ & $\begin{array}{c}\text { total } \\
(n=71)\end{array}$ \\
\hline
\end{tabular}

\section{Dioscoreaceae}

$\begin{array}{rc}\text { Dioscorea sp. } & \text { cará amarelo } \\ \text { Dioscorea sp. } & \text { cará branco (indaiá) } \\ \text { Dioscorea sp. } & \text { cará butija (redondo) } \\ \text { Dioscorea sp. } & \text { cará chato } \\ \text { Dioscorea sp. } & \text { cará de alho } \\ \text { Dioscorea sp. } & \text { cará de cinta } \\ \text { Dioscorea bulbifera L. } & \text { cará de corda (cipó) } \\ \text { Dioscorea sp. } & \text { cará de espinho (angola) } \\ \text { Dioscorea sp. } & \text { cará de horta } \\ \text { Dioscorea sp. } & \text { cará figo } \\ \text { Dioscorea sp. } & \text { cará moela (sopa) } \\ \text { Dioscorea sp. } & \text { cará mole } \\ \text { Dioscorea sp. } & \text { cará roxo } \\ \text { Dioscorea sp. } & \text { cará samboá }\end{array}$

\section{Oc Oc Oc Oc}

Fr. Uso

\section{Dioscoreaceae}

\section{Ebenaceae}

Diospyros kaki L. f.

$\begin{array}{lccccc}0 & 2 & 0 & 2 & 0,03 & 1 \\ 1 & 2 & 3 & 6 & 0,08 & 1 \\ 0 & 0 & 1 & 1 & 0,01 & 1 \\ 1 & 1 & 0 & 2 & 0,03 & 1 \\ 0 & 1 & 0 & 1 & 0,01 & 1 \\ 1 & 0 & 0 & 1 & 0,01 & 1 \\ 2 & 0 & 0 & 2 & 0,03 & 1 \\ 8 & 10 & 5 & 23 & 0,32 & 1 \\ 1 & 0 & 0 & 1 & 0,01 & 1 \\ 0 & 0 & 1 & 1 & 0,01 & 1 \\ 1 & 3 & 0 & 4 & 0,06 & 1 \\ 1 & 1 & 0 & 2 & 0,03 & 1 \\ 0 & 1 & 0 & 1 & 0,01 & 1 \\ 1 & 0 & 0 & 1 & 0,01 & 1\end{array}$


Continuação: Etnovariedades parcial ou totalmente identificadas presentes nos jardins quintal das comunidades quilombolas de Sapatu, São Pedro e Pedro Cubas, município de Eldorado Paulista, SP. (SAP: Sapatu; PEC: Pedro Cubas; SP: São Pedro; Oc: ocorrência; $\mathbf{n}$ : número de unidades domésticas visitadas por comunidade; Fr.: frequencia relativa ( $\mathrm{n}=71)$; Uso: 1 = alimentação; 2 = medicinal; $\mathbf{3}$ = ornamental; $\mathbf{4}$ = simbólico-afetiva; 5 = outros)

\begin{tabular}{|c|c|c|c|c|c|c|c|}
\hline espécie biológica & denominação local & $\begin{array}{c}\text { SAP } \\
(\mathrm{n}=30)\end{array}$ & $\begin{array}{c}\text { PEC } \\
(\mathrm{n}=27)\end{array}$ & $\begin{array}{c}\text { SP } \\
(n=14)\end{array}$ & $\begin{array}{c}\text { total } \\
(\mathrm{n}=71)\end{array}$ & & \\
\hline & & Oc & Oc & Oc & Oc & Fr. & Uso \\
\hline \multicolumn{8}{|l|}{ Euphorbiaceae } \\
\hline Euphorbia pulcherrima Willd. ex Klotzsch & bico de corvo, de papagaio & 0 & 3 & 0 & 3 & 0,04 & 2,3 \\
\hline Jatropha gossypiifolia L. & carube (pinho roxo) & 3 & 2 & 6 & 11 & 0,15 & 3 \\
\hline Euphorbia sp. & fura zóio & 0 & 0 & 2 & 2 & 0,03 & 3 \\
\hline Breynia nivosa (W.G. Sm.) Small & geada (serena da noite) & 2 & 0 & 0 & 2 & 0,03 & 3 \\
\hline Euphorbia sp. & jacaré & 0 & 0 & 1 & 1 & 0,01 & 3 \\
\hline Ricinus communis $\mathrm{L}$. & mamona & 3 & 2 & 2 & 7 & 0,10 & 4,5 \\
\hline Manihot esculenta Crantz & mandioca & 2 & 3 & 1 & 6 & 0,08 & 1 \\
\hline Manihot esculenta Crantz & mandioca aimpim branco & 1 & 3 & 3 & 7 & 0,10 & 1 \\
\hline Manihot esculenta Crantz & mandioca de laboratório & 0 & 1 & 0 & 1 & 0,01 & 1 \\
\hline Manihot esculenta Crantz & mandioca mansa (amarela) & 5 & 1 & 2 & 8 & 0,11 & 1 \\
\hline Manihot esculenta Crantz & mandioca pão do céu & 0 & 0 & 1 & 1 & 0,01 & 1 \\
\hline Manihot esculenta Crantz & mandioca roxa, rosa & 12 & 5 & 3 & 20 & 0,28 & 1 \\
\hline Manihot esculenta Crantz & mandioca São José & 0 & 0 & 1 & 1 & 0,01 & 1 \\
\hline Manihot esculenta Crantz & mandioca São Sebastião & 0 & 0 & 1 & 1 & 0,01 & 1 \\
\hline Manihot esculenta Crantz & mandioca saranduva & 1 & 0 & 0 & 1 & 0,01 & 1 \\
\hline Manihot esculenta Crantz & mandioca vassourinha & 0 & 3 & 0 & 3 & 0,04 & 1 \\
\hline Acalypha wilkesiana Mull & não denominada & 1 & 0 & 0 & 1 & 0,01 & 3 \\
\hline Alchornea cf glandulosa Poepp. & não denominada & 1 & 0 & 0 & 1 & 0,01 & 2 \\
\hline
\end{tabular}


Continuação: Etnovariedades parcial ou totalmente identificadas presentes nos jardins quintal das comunidades quilombolas de Sapatu, São Pedro e Pedro Cubas, município de Eldorado Paulista, SP. (SAP: Sapatu; PEC: Pedro Cubas; SP: São Pedro; Oc: ocorrência; $\mathbf{n}$ : número de unidades domésticas visitadas por comunidade; Fr.: frequencia relativa ( $\mathrm{n}=71)$; Uso: 1 = alimentação; 2 = medicinal; $\mathbf{3}$ = ornamental; $\mathbf{4}$ = simbólico-afetiva; $\mathbf{5}$ = outros)

\begin{tabular}{|c|c|c|c|c|c|c|c|}
\hline espécie biológica & denominação local & $\begin{array}{c}\text { SAP } \\
(\mathrm{n}=30)\end{array}$ & $\begin{array}{c}\text { PEC } \\
(\mathrm{n}=27)\end{array}$ & $\begin{array}{c}\text { SP } \\
(n=14)\end{array}$ & $\begin{array}{c}\text { total } \\
(\mathrm{n}=71)\end{array}$ & & \\
\hline & & Oc & Oc & Oc & Oc & Fr. & Uso \\
\hline \multicolumn{8}{|l|}{ Euphorbiaceae } \\
\hline Codiaeum variegatum (L.) Blume & não denominada & 1 & 0 & 0 & 1 & 0,01 & 3 \\
\hline Pedilanthus tithymaloides (L.) Poit. & não denominada & 4 & 0 & 1 & 5 & 0,07 & 3 \\
\hline Phyllanthus niruri L. & quebra pedra & 2 & 1 & 1 & 4 & 0,06 & 2 \\
\hline sem identificação & avelã & 0 & 5 & 0 & 5 & 0,07 & 2 \\
\hline sem identificação & lacuspida & 2 & 0 & 0 & 2 & 0,03 & 3 \\
\hline \multicolumn{8}{|l|}{ Fabaceae } \\
\hline Senna speciosa Roxb. & caquera & 4 & 5 & 1 & 10 & 0,14 & $3,4,5$ \\
\hline Senna multijuga (Rich.) H.S. Irwin \& Barneby & caquera (outra qualidade) & 0 & 0 & 1 & 1 & 0,01 & $3,4,5$ \\
\hline Senna sp. & $\begin{array}{c}\text { fedegoso } \\
\text { feijão fava (vagem, corda, }\end{array}$ & 2 & 0 & 0 & 2 & 0,03 & 2,4 \\
\hline Phaseolus lunatus L. & trepadeira) & 3 & 3 & 2 & 8 & 0,11 & 1 \\
\hline Phaseolus vulgaris $\mathrm{L}$. & feijão bico de ouro & 0 & 1 & 0 & 1 & 0,01 & 1 \\
\hline Phaseolus vulgaris L. & feijão carioca & 4 & 0 & 0 & 4 & 0,06 & 1 \\
\hline Phaseolus vulgaris $\mathrm{L}$. & feijão guandu & 0 & 2 & 1 & 3 & 0,04 & 1 \\
\hline Schizolobium parahyba (Vell.) S.F. Blake & guapuruvu & 1 & 0 & 0 & 1 & 0,01 & 3,5 \\
\hline Ormosia sp. & não denominada & 1 & 0 & 1 & 2 & 0,03 & 1 \\
\hline Senna sp. & não denominada & 0 & 1 & 0 & 1 & 0,01 & 3 \\
\hline Ormosia arborea (Vell.) Harms & olho de cabra & 1 & 0 & 0 & 1 & 0,01 & 3 \\
\hline
\end{tabular}


Continuação: Etnovariedades parcial ou totalmente identificadas presentes nos jardins quintal das comunidades quilombolas de Sapatu, São Pedro e Pedro Cubas, município de Eldorado Paulista, SP. (SAP: Sapatu; PEC: Pedro Cubas; SP: São Pedro; Oc: ocorrência; $\mathbf{n}$ : número de unidades domésticas visitadas por comunidade; Fr.: frequencia relativa ( $\mathrm{n}=71)$; Uso: 1 = alimentação; 2 = medicinal; $\mathbf{3}$ = ornamental; $\mathbf{4}$ = simbólico-afetiva; $\mathbf{5}$ = outros)

\begin{tabular}{|c|c|c|c|c|c|c|}
\hline família & espécie biológica & denominação local & $\begin{array}{c}\text { SAP } \\
(n=30)\end{array}$ & $\begin{array}{c}\text { PEC } \\
(\mathrm{n}=27)\end{array}$ & $\begin{array}{c}\mathbf{S P} \\
(\mathrm{n}=14)\end{array}$ & $\begin{array}{c}\text { total } \\
(\mathrm{n}=71)\end{array}$ \\
\hline
\end{tabular}

\section{Fabaceae}

\begin{tabular}{|c|c|c|c|c|c|c|c|}
\hline Bauhinia variegata $\mathrm{L}$. & pata de vaca & 3 & 0 & 1 & 4 & 0,06 & 3 \\
\hline Caesalpinia echinata Lam. & pau brasil & 2 & 1 & 0 & 3 & 0,04 & 3,5 \\
\hline Machaerium cf aculeatum Raddi & sapateiro (com espinhos) & 2 & 0 & 0 & 2 & 0,03 & 5 \\
\hline Senna sp. & sene & 0 & 0 & 3 & 3 & 0,04 & 2 \\
\hline Delonix regia (Bojer) Raf. & sombreiro & 1 & 0 & 2 & 3 & 0,04 & 3,5 \\
\hline Erythrina speciosa Andrews & sunã (avelã) & 0 & 0 & 1 & 1 & 0,01 & 3,5 \\
\hline Machaerium uncinatum (Vell.) Benth. & unha de gato & 0 & 1 & 1 & 2 & 0,03 & 2 \\
\hline sem identificação & caquera (outra qualidade) & 1 & 4 & 3 & 8 & 0,11 & 4,5 \\
\hline sem identificação & ipê & 1 & 0 & 0 & 1 & 0,01 & 3 \\
\hline sem identificação & não denominada & 1 & 0 & 0 & 1 & 0,01 & 3,5 \\
\hline sem identificação & não denominada & 1 & 0 & 0 & 1 & 0,01 & 3,5 \\
\hline sem identificação & sombreiro & 4 & 1 & 2 & 7 & 0,10 & 5 \\
\hline sem identificação & terereca & 0 & 1 & 1 & 2 & 0,03 & 5 \\
\hline
\end{tabular}

\section{Flacourtiaceae}


Continuação: Etnovariedades parcial ou totalmente identificadas presentes nos jardins quintal das comunidades quilombolas de Sapatu, São Pedro e Pedro Cubas, município de Eldorado Paulista, SP. (SAP: Sapatu; PEC: Pedro Cubas; SP: São Pedro; Oc: ocorrência; $\mathbf{n}$ : número de unidades domésticas visitadas por comunidade; Fr.: frequencia relativa ( $\mathrm{n}=71)$; Uso: 1 = alimentação; 2 = medicinal; $\mathbf{3}$ = ornamental; $\mathbf{4}$ = simbólico-afetiva; 5 = outros)

\begin{tabular}{|c|c|c|c|c|c|c|c|}
\hline espécie biológica & denominação local & $\begin{array}{c}\text { SAP } \\
(\mathrm{n}=30)\end{array}$ & $\begin{array}{c}\text { PEC } \\
(\mathrm{n}=27)\end{array}$ & $\begin{array}{c}\text { SP } \\
(n=14)\end{array}$ & $\begin{array}{c}\text { total } \\
(\mathrm{n}=71)\end{array}$ & & \\
\hline & & Oc & Oc & Oc & Oc & Fr. & Uso \\
\hline \multicolumn{8}{|l|}{ Geraniaceae } \\
\hline Pelargonium sp. & não denominada & 1 & 0 & 0 & 1 & 0,01 & 3 \\
\hline \multicolumn{8}{|l|}{ Gesneriaceae } \\
\hline Episcia fulgida (Linden) Hook. f. & não denominada & 2 & 2 & 0 & 4 & 0,06 & 3 \\
\hline \multicolumn{8}{|l|}{ Hydrangeaceae } \\
\hline Hydrangea macrophylla (Thunb.) Ser. & hortência & 2 & 0 & 0 & 2 & 0,03 & 3 \\
\hline \multicolumn{8}{|l|}{ Iridaceae } \\
\hline sem identificação & não denominada & 1 & 0 & 0 & 1 & 0,01 & 3 \\
\hline \multicolumn{8}{|l|}{ Lamiaceae } \\
\hline Rosmarinus officinalis $\mathrm{L}$. & alecrim & 4 & 0 & 1 & 5 & 0,07 & 2 \\
\hline Plectranthus barbatus Andrews & boldo & 5 & 7 & 3 & 15 & 0,21 & 2 \\
\hline Melissa officinalis L. & erva cidreira & 3 & 8 & 5 & 16 & 0,23 & 2 \\
\hline Solenostemon scutellarioides (L.) Codd. & folhagem & 1 & 3 & 0 & 4 & 0,06 & 3 \\
\hline Mentha spicata L. & hortelã (branco) & 10 & 4 & 2 & 16 & 0,23 & 1,2 \\
\hline Plectranthus amboinicus (Lour.) Spreng. & hortelã gorda, folha gorda & 12 & 3 & 4 & 19 & 0,27 & 2 \\
\hline
\end{tabular}


Continuação: Etnovariedades parcial ou totalmente identificadas presentes nos jardins quintal das comunidades quilombolas de Sapatu, São Pedro e Pedro Cubas, município de Eldorado Paulista, SP. (SAP: Sapatu; PEC: Pedro Cubas; SP: São Pedro; Oc: ocorrência; $\mathbf{n}$ : número de unidades domésticas visitadas por comunidade; Fr.: frequencia relativa ( $\mathrm{n}=71)$; Uso: 1 = alimentação; 2 = medicinal; $\mathbf{3}$ = ornamental; $\mathbf{4}$ = simbólico-afetiva; $\mathbf{5}$ = outros)

\begin{tabular}{|c|c|c|c|c|c|c|c|c|}
\hline família & espécie biológica & denominação local & $\begin{array}{c}\text { SAP } \\
(\mathrm{n}=30)\end{array}$ & $\begin{array}{c}\text { PEC } \\
(\mathrm{n}=27)\end{array}$ & $\begin{array}{c}\text { SP } \\
(n=14)\end{array}$ & $\begin{array}{c}\text { total } \\
(\mathrm{n}=71)\end{array}$ & & \\
\hline & & & Oc & Oc & Oc & Oc & Fr. & Uso \\
\hline \multicolumn{9}{|c|}{ Lamiaceae } \\
\hline & Mentha sp & hortelã grande & 2 & 0 & 0 & 2 & 0,03 & 2 \\
\hline & Menthasp & hortelã levante & 0 & 0 & 1 & 1 & 0,01 & 2 \\
\hline & Mentha piperita L. & hortelã pimenta & 7 & 3 & 1 & 11 & 0,15 & 2 \\
\hline & Mentha spicata L. & hortelã preta & 1 & 0 & 1 & 2 & 0,03 & 2 \\
\hline & Ocimum basilicum L. & manjericão & 4 & 4 & 3 & 11 & 0,15 & 1 \\
\hline & Origanum majorana L. & manjerona & 6 & 1 & 4 & 11 & 0,15 & 1 \\
\hline & Coleus sp & não denominada & 2 & 0 & 0 & 2 & 0,03 & 2 \\
\hline & Leonurus sp. & não denominada & 1 & 0 & 0 & 1 & 0,01 & 2,5 \\
\hline & Menthasp & não denominada & 1 & 0 & 0 & 1 & 0,01 & 2 \\
\hline & Mentha sp & não denominada & 1 & 0 & 0 & 1 & 0,01 & 2 \\
\hline & Ocimum americanum $\mathrm{L}$. & não denominada & 0 & 1 & 0 & 1 & 0,01 & 2 \\
\hline & Mentha pulegium L. & puejo & 4 & 3 & 2 & 9 & 0,13 & 2 \\
\hline & Leonurus sp. & rubi, rubim & 1 & 1 & 2 & 4 & 0,06 & 2,5 \\
\hline & Ocimum sp. & alfavaca & 10 & 11 & 7 & 28 & 0,39 & 1 \\
\hline & Ocimum basilicum $\mathrm{L}$. & alfavacão (chá calmante) & 1 & 1 & 1 & 3 & 0,04 & 2 \\
\hline & sem identificação & não denominada & 1 & 0 & 0 & 1 & 0,01 & 1 \\
\hline
\end{tabular}


Continuação: Etnovariedades parcial ou totalmente identificadas presentes nos jardins quintal das comunidades quilombolas de Sapatu, São Pedro e Pedro Cubas, município de Eldorado Paulista, SP. (SAP: Sapatu; PEC: Pedro Cubas; SP: São Pedro; Oc: ocorrência; $\mathbf{n}$ : número de unidades domésticas visitadas por comunidade; Fr.: frequencia relativa ( $\mathrm{n}=71)$; Uso: 1 = alimentação; 2 = medicinal; $\mathbf{3}$ = ornamental; $\mathbf{4}$ = simbólico-afetiva; $\mathbf{5}$ = outros)

\begin{tabular}{|c|c|c|c|c|c|c|}
\hline família & espécie biológica & denominação local & $\begin{array}{c}\text { SAP } \\
(n=30)\end{array}$ & $\begin{array}{c}\text { PEC } \\
(\mathrm{n}=27)\end{array}$ & $\begin{array}{c}\mathbf{S P} \\
(\mathrm{n}=14)\end{array}$ & $\begin{array}{c}\text { total } \\
(\mathrm{n}=71)\end{array}$ \\
\hline
\end{tabular}

Lauraceae

Persea gratissima Gaertn.

Persea sp.

Laurus nobilis L.

Persea americana Mill

\section{Liliaceae}

Aloe vera (L.) Burm. $\mathrm{f}$.

Cordyline terminalis (L.) Kunth

Cordyline cf fruticosa (L.) A. Chev.

Sansevieria trifasciata Hort. ex Prain.

Cordyline sp.

Ophiopogon japonicus (L. f.) Ker Gawl.

Chlorophytum sp.

Sansevieria trifasciata Prain

Dracaena sp. abacate (outra qualidade)

abacate do mato

$$
\text { losma }
$$

abacate

\section{Oc Oc Oc Oc}

Fr. Uso

$\begin{array}{cccccc}0 & 1 & 0 & 1 & 0,01 & 1 \\ 1 & 0 & 1 & 2 & 0,03 & 1 \\ 0 & 1 & 0 & 1 & 0,01 & 2 \\ 20 & 13 & 8 & 41 & 0,58 & 1\end{array}$

coqueiro (preto, vermelho,

flor de cemiterio)

coqueiro branco (palma)

espada de São Jorge

espetadinha

grama negra

não denominada

orelha de burro

pino

$\begin{array}{ll}6 & 2 \\ 3 & 6 \\ 6 & 6 \\ 6 & 6 \\ 0 & 0 \\ 6 & 0 \\ 1 & 0 \\ 1 & 0 \\ 1 & 0\end{array}$

0,24

2,5

0,20

3,4

$0,25 \quad 3,4$

$0,28 \quad 3,4$

$0,01 \quad 3$

$0,08 \quad 3$

$0,01 \quad 3$

$0,01 \quad 3$

$0,01 \quad 3$

\section{Loganiaceae}

Strychnos trinervis (Vell) Mart

cipó cruz

0

1

0

1

0,01 
Continuação: Etnovariedades parcial ou totalmente identificadas presentes nos jardins quintal das comunidades quilombolas de Sapatu, São Pedro e Pedro Cubas, município de Eldorado Paulista, SP. (SAP: Sapatu; PEC: Pedro Cubas; SP: São Pedro; Oc: ocorrência; $\mathbf{n}$ : número de unidades domésticas visitadas por comunidade; Fr.: frequencia relativa ( $\mathrm{n}=71)$; Uso: 1 = alimentação; $\mathbf{2}=$ medicinal; $\mathbf{3}$ = ornamental; $\mathbf{4}$ = simbólico-afetiva; $\mathbf{5}$ = outros)

\begin{tabular}{|c|c|c|c|c|c|c|c|}
\hline espécie biológica & denominação local & $\begin{array}{c}\text { SAP } \\
(\mathrm{n}=30)\end{array}$ & $\begin{array}{c}\text { PEC } \\
(\mathrm{n}=27)\end{array}$ & $\begin{array}{c}\mathbf{S P} \\
(\mathrm{n}=14)\end{array}$ & $\begin{array}{c}\text { total } \\
(\mathrm{n}=71)\end{array}$ & & \\
\hline & & Oc & Oc & Oc & Oc & Fr. & Uso \\
\hline \multicolumn{8}{|l|}{ Lythraceae } \\
\hline Cuphea sp. & não denominada & 1 & 0 & 0 & 1 & 0,01 & 2 \\
\hline \multicolumn{8}{|l|}{ Malphighiaceae } \\
\hline Malphighia glabra L. & acerola & 5 & 6 & 3 & 14 & 0,20 & 1 \\
\hline Malpighia emarginata DC & não denominada & 0 & 0 & 1 & 1 & 0,01 & 1 \\
\hline \multicolumn{8}{|l|}{ Malvaceae } \\
\hline Gossypium hirsutum L. & algodão & 3 & 2 & 1 & 6 & 0,08 & 2,5 \\
\hline Gossypium hirsutum L. & algodão (outra qualidade) & 0 & 1 & 0 & 1 & 0,01 & 5 \\
\hline Hibiscus sp. & $\begin{array}{c}\text { beijo } \\
\text { fogueteiro (cerca viva, }\end{array}$ & 0 & 0 & 1 & 1 & 0,01 & 3 \\
\hline Malvaviscus arboreus Cav. & sapateiro) & 22 & 5 & 6 & 33 & 0,46 & 3,5 \\
\hline Hibiscus sp. & hibisco escuro & 2 & 0 & 2 & 4 & 0,06 & 3 \\
\hline Hibiscus sp. & não denominada & 0 & 2 & 0 & 2 & 0,03 & 3 \\
\hline Abelmoschus esculentus (L.) Moench & quiabo & 4 & 6 & 0 & 10 & 0,14 & 1 \\
\hline Malvaviscum sp. & sapateiro & 7 & 0 & 1 & 8 & 0,11 & 3,5 \\
\hline Sida sp. & vassourinha, guanxuma & 12 & 9 & 8 & 29 & 0,41 & 5 \\
\hline sem identificação & malva & 4 & 0 & 0 & 4 & 0,06 & 2 \\
\hline sem identificação & muchita & 0 & 2 & 0 & 2 & 0,03 & 2 \\
\hline
\end{tabular}


Continuação: Etnovariedades parcial ou totalmente identificadas presentes nos jardins quintal das comunidades quilombolas de Sapatu, São Pedro e Pedro Cubas, município de Eldorado Paulista, SP. (SAP: Sapatu; PEC: Pedro Cubas; SP: São Pedro; Oc: ocorrência; $\mathbf{n}$ : número de unidades domésticas visitadas por comunidade; Fr.: frequencia relativa ( $\mathrm{n}=71)$; Uso: 1 = alimentação; 2 = medicinal; $\mathbf{3}$ = ornamental; $\mathbf{4}$ = simbólico-afetiva; $\mathbf{5}$ = outros)

\begin{tabular}{|c|c|c|c|c|c|c|}
\hline família & espécie biológica & denominação local & $\begin{array}{c}\text { SAP } \\
(\mathrm{n}=30)\end{array}$ & $\begin{array}{c}\text { PEC } \\
(\mathrm{n}=27)\end{array}$ & $\begin{array}{c}\text { SP } \\
(n=14)\end{array}$ & $\begin{array}{c}\text { total } \\
(n=71)\end{array}$ \\
\hline
\end{tabular}

\section{Malvaceae}

sem identificação sem identificação

Ctenanthe sp. Calathea sp.

\section{Melastomataceae}

Tibouchina cf grandifolia Cogn.

Tibouchina sp.

Tibouchina pulchra Cogn.

Tibouchina sp.

Clidemia sp.

sem identificação

sem identificação

\section{não denominada}

não denominada

caetê do mato biri (outra qualidade)

\section{Oc Oc Oc Oc}

Fr. Uso

$\begin{array}{llllll}0 & 0 & 1 & 1 & 0,01 & 3\end{array}$

$\begin{array}{llllll}0 & 1 & 0 & 1 & 0,01 & 3\end{array}$

não denominada

não denominada

natal

natalzinho

pixirica

não denominada

não denominada

$\begin{array}{llllll}0 & 1 & 0 & 1 & 0,01 & 3 \\ 1 & 0 & 0 & 1 & 0,01 & 3\end{array}$

\section{Meliaceae}


Continuação: Etnovariedades parcial ou totalmente identificadas presentes nos jardins quintal das comunidades quilombolas de Sapatu, São Pedro e Pedro Cubas, município de Eldorado Paulista, SP. (SAP: Sapatu; PEC: Pedro Cubas; SP: São Pedro; Oc: ocorrência; $\mathbf{n}$ : número de unidades domésticas visitadas por comunidade; Fr.: frequencia relativa ( $\mathrm{n}=71)$; Uso: 1 = alimentação; 2 = medicinal; $\mathbf{3}$ = ornamental; $\mathbf{4}$ = simbólico-afetiva; $\mathbf{5}$ = outros)

\begin{tabular}{|c|c|c|c|c|c|c|c|}
\hline espécie biológica & denominação local & $\begin{array}{c}\text { SAP } \\
(\mathrm{n}=30)\end{array}$ & $\begin{array}{c}\text { PEC } \\
(\mathrm{n}=27)\end{array}$ & $\begin{array}{c}\text { SP } \\
(n=14)\end{array}$ & $\begin{array}{c}\text { total } \\
(\mathrm{n}=71)\end{array}$ & & \\
\hline & & Oc & Oc & Oc & Oc & Fr. & Uso \\
\hline \multicolumn{8}{|l|}{ Monimiaceae } \\
\hline Peumus boldus Molina & boldo do chile & 1 & 1 & 3 & 5 & 0,07 & 2 \\
\hline \multicolumn{8}{|l|}{ Moraceae } \\
\hline Morus nigra L. & amora & 11 & 6 & 2 & 19 & 0,27 & 1 \\
\hline Morus sp. & amora de folha rachada & 0 & 1 & 0 & 1 & 0,01 & 1 \\
\hline Ficus sp. & figueira & 3 & 1 & 0 & 4 & 0,06 & 5 \\
\hline Artocarpus heterophyllus Lam. & jaca & 16 & 12 & 1 & 29 & 0,41 & 1 \\
\hline \multicolumn{8}{|l|}{ Musaceae } \\
\hline Musa sp. & banana & 0 & 1 & 0 & 1 & 0,01 & 1,5 \\
\hline Musa sp. & banana cacau & 1 & 0 & 0 & 1 & 0,01 & 1,5 \\
\hline Musa sp. & banana caturra & 0 & 0 & 1 & 1 & 0,01 & 1,5 \\
\hline Musa sp. & banana cinza & 0 & 0 & 4 & 4 & 0,06 & 1,5 \\
\hline Musa paradisiaca L. & banana maçã (branca) & 9 & 9 & 5 & 23 & 0,32 & 1,5 \\
\hline Musa sapientum L. & banana maranhão (terra) & 4 & 8 & 3 & 15 & 0,21 & 1,5 \\
\hline Musa sinensis L. & banana nanica & 18 & 10 & 7 & 35 & 0,49 & 1,5 \\
\hline Musa cavendishii var. nanicao Lamb. & banana nanicão & 1 & 0 & 0 & 1 & 0,01 & 1,5 \\
\hline Musa paradisiaca L. & banana ouro (pêra) & 9 & 6 & 5 & 20 & 0,28 & 1,5 \\
\hline
\end{tabular}


Continuação: Etnovariedades parcial ou totalmente identificadas presentes nos jardins quintal das comunidades quilombolas de Sapatu, São Pedro e Pedro Cubas, município de Eldorado Paulista, SP. (SAP: Sapatu; PEC: Pedro Cubas; SP: São Pedro; Oc: ocorrência; $\mathbf{n}$ : número de unidades domésticas visitadas por comunidade; Fr.: frequencia relativa ( $\mathrm{n}=71)$; Uso: 1 = alimentação; 2 = medicinal; $\mathbf{3}$ = ornamental; $\mathbf{4}$ = simbólico-afetiva; $\mathbf{5}$ = outros)

\begin{tabular}{|c|c|c|c|c|c|c|c|}
\hline espécie biológica & denominação local & $\begin{array}{c}\text { SAP } \\
(n=30)\end{array}$ & $\begin{array}{c}\text { PEC } \\
(\mathrm{n}=27)\end{array}$ & $\begin{array}{c}\mathbf{S P} \\
(\mathrm{n}=14)\end{array}$ & $\begin{array}{c}\text { total } \\
(\mathrm{n}=71)\end{array}$ & & \\
\hline & & Oc & Oc & Oc & Oc & Fr. & Uso \\
\hline \multicolumn{8}{|l|}{ Musaceae } \\
\hline Musa sp. & banana pacova & 0 & 0 & 1 & 1 & 0,01 & 1,5 \\
\hline Musa sp. & banana pão & 0 & 1 & 0 & 1 & 0,01 & 1,5 \\
\hline Musa paradisiaca L. & banana prata & 6 & 3 & 0 & 9 & 0,13 & 1,5 \\
\hline Musa sp. & banana roxa & 1 & 0 & 0 & 1 & 0,01 & 1,5 \\
\hline Musa sp. & banana vinagre (preta) & 6 & 1 & 0 & 7 & 0,10 & 1,5 \\
\hline Musa sp. & banana zinca & 5 & 1 & 3 & 9 & 0,13 & 1,5 \\
\hline \multicolumn{8}{|l|}{ Myrsinaceae } \\
\hline Rapanea ferruginea (Ruiz \& Pav.) Mez & tapororoca & 0 & 2 & 0 & 2 & 0,03 & 5 \\
\hline \multicolumn{8}{|l|}{ Myrtaceae } \\
\hline Psidium cattleyanum $\mathrm{L}$. & araçá & 0 & 4 & 0 & 4 & 0,06 & 1 \\
\hline Eugenia sp. & camarinha & 7 & 3 & 5 & 15 & 0,21 & $1,4,5$ \\
\hline Campomanesia xantocarpa O. Berg. & gaviroba (gabiroba) & 3 & 1 & 0 & 4 & 0,06 & 4,5 \\
\hline Psidium guajava $\mathrm{L}$. & goiaba (branca e vermelha) & 28 & 25 & 11 & 64 & 0,90 & 1 \\
\hline Myrciaria cauliflora (Mart.) O. Berg & jaboticaba & 12 & 7 & 4 & 23 & 0,32 & 1 \\
\hline Eugenia malaccensis L. & jambo & 7 & 10 & 1 & 18 & 0,25 & 1,5 \\
\hline
\end{tabular}


Continuação: Etnovariedades parcial ou totalmente identificadas presentes nos jardins quintal das comunidades quilombolas de Sapatu, São Pedro e Pedro Cubas, município de Eldorado Paulista, SP. (SAP: Sapatu; PEC: Pedro Cubas; SP: São Pedro; Oc: ocorrência; $\mathbf{n}$ : número de unidades domésticas visitadas por comunidade; Fr.: frequencia relativa ( $\mathrm{n}=71)$; Uso: 1 = alimentação; 2 = medicinal; $\mathbf{3}$ = ornamental; $\mathbf{4}$ = simbólico-afetiva; 5 = outros)

\begin{tabular}{|c|c|c|c|c|c|c|c|c|}
\hline família & espécie biológica & denominação local & $\begin{array}{c}\text { SAP } \\
(n=30)\end{array}$ & $\begin{array}{c}\text { PEC } \\
(\mathrm{n}=27)\end{array}$ & $\begin{array}{c}\text { SP } \\
(n=14)\end{array}$ & $\begin{array}{c}\text { total } \\
(\mathrm{n}=71)\end{array}$ & & \\
\hline & & & Oc & Oc & Oc & Oc & Fr. & Uso \\
\hline \multicolumn{9}{|c|}{ Myrtaceae } \\
\hline & Eugenia uniflora O. Berg. & pitanga & 4 & 8 & 4 & 16 & 0,23 & 1 \\
\hline & sem identificação & não denominada & 1 & 0 & 1 & 2 & 0,03 & 2 \\
\hline \multicolumn{9}{|c|}{ Nyctaginaceae } \\
\hline & Bouganvillea spectabilis Willd & primavera & 0 & 2 & 0 & 2 & 0,03 & 3 \\
\hline \multicolumn{9}{|c|}{ Oleaceae } \\
\hline & Olea europaea L. & azeitona & 1 & 0 & 0 & 1 & 0,01 & 1 \\
\hline \multicolumn{9}{|c|}{ Orchidaceae } \\
\hline & Oncidium sp & chuva de ouro & 0 & 0 & 1 & 1 & 0,01 & 3 \\
\hline & sem identificação & não denominada & 0 & 1 & 0 & 1 & 0,01 & 3 \\
\hline & sem identificação & orquidea & 4 & 4 & 4 & 12 & 0,17 & 3 \\
\hline & sem identificação & parasita & 2 & 2 & 0 & 4 & 0,06 & 3 \\
\hline \multicolumn{9}{|c|}{ Oxalidaceae } \\
\hline & Averrhoa carambola L. & carambola & 4 & 1 & 1 & 6 & 0,08 & 1 \\
\hline
\end{tabular}


Continuação: Etnovariedades parcial ou totalmente identificadas presentes nos jardins quintal das comunidades quilombolas de Sapatu, São Pedro e Pedro Cubas, município de Eldorado Paulista, SP. (SAP: Sapatu; PEC: Pedro Cubas; SP: São Pedro; Oc: ocorrência; $\mathbf{n}$ : número de unidades domésticas visitadas por comunidade; Fr.: frequencia relativa ( $\mathrm{n}=71)$; Uso: 1 = alimentação; 2 = medicinal; $\mathbf{3}$ = ornamental; 4 = simbólico-afetiva; 5 = outros)

\begin{tabular}{|c|c|c|c|c|c|c|c|}
\hline espécie biológica & denominação local & $\begin{array}{c}\text { SAP } \\
(\mathrm{n}=30)\end{array}$ & $\begin{array}{c}\text { PEC } \\
(\mathrm{n}=27)\end{array}$ & $\begin{array}{c}\mathbf{S P} \\
(n=14)\end{array}$ & $\begin{array}{c}\text { total } \\
(\mathrm{n}=71)\end{array}$ & & \\
\hline & & Oc & Oc & Oc & Oc & Fr. & Uso \\
\hline \multicolumn{8}{|l|}{ Passifloraceae } \\
\hline Passiflora edulis Sims & maracujá amarelo, grande & 15 & 12 & 10 & 37 & 0,52 & 1,5 \\
\hline Passiflora edulis Sims & maracujá preto, pequeno & 1 & 0 & 0 & 1 & 0,01 & 1,5 \\
\hline \multicolumn{8}{|l|}{ Phytolaccaceae } \\
\hline Phytolacca thyrsiflora Fenzl ex Schmidt & avelã roxo & 0 & 0 & 1 & 1 & 0,01 & 2 \\
\hline Petiveria alliacea L. & guiné & 4 & 2 & 4 & 10 & 0,14 & 2,4 \\
\hline \multicolumn{8}{|l|}{ Pinaceae } \\
\hline Pinus elliotti L. & pé de pinha & 0 & 1 & 0 & 1 & 0,01 & 3,5 \\
\hline \multicolumn{8}{|l|}{ Piperaceae } \\
\hline Piper aduncum L. & jaguarandi (jaborandi) & 3 & 4 & 1 & 8 & 0,11 & 2 \\
\hline Pothomorphe umbellata (L.) Miq. & paparova & 1 & 0 & 0 & 1 & 0,01 & 2 \\
\hline & não denominada & 0 & 1 & 1 & 2 & 0,03 & 2 \\
\hline \multicolumn{8}{|l|}{ Plantaginaceae } \\
\hline Plantago cf major L. & tanchais & 2 & 0 & 0 & 2 & 0,03 & 2 \\
\hline
\end{tabular}


Continuação: Etnovariedades parcial ou totalmente identificadas presentes nos jardins quintal das comunidades quilombolas de Sapatu, São Pedro e Pedro Cubas, município de Eldorado Paulista, SP. (SAP: Sapatu; PEC: Pedro Cubas; SP: São Pedro; Oc: ocorrência; $\mathbf{n}$ : número de unidades domésticas visitadas por comunidade; Fr.: frequencia relativa ( $\mathrm{n}=71)$; Uso: 1 = alimentação; 2 = medicinal; $\mathbf{3}$ = ornamental; $\mathbf{4}$ = simbólico-afetiva; $\mathbf{5}$ = outros)

\begin{tabular}{|c|c|c|c|c|c|c|c|c|}
\hline família & espécie biológica & denominação local & $\begin{array}{c}\text { SAP } \\
(\mathrm{n}=30)\end{array}$ & $\begin{array}{c}\text { PEC } \\
(\mathrm{n}=27)\end{array}$ & $\begin{array}{c}\text { SP } \\
(n=14)\end{array}$ & $\begin{array}{c}\text { total } \\
(\mathrm{n}=71)\end{array}$ & & \\
\hline & & & Oc & Oc & Oc & Oc & Fr. & Uso \\
\hline \multicolumn{9}{|c|}{ Poaceae } \\
\hline & Zea mays L. & milho & 3 & 3 & 2 & 8 & 0,11 & 1 \\
\hline & Pennisetum americanum L. & campim napier & 0 & 1 & 0 & 1 & 0,01 & 5 \\
\hline & Saccharum officinarum L. & cana & 3 & 1 & 0 & 4 & 0,06 & 1 \\
\hline & Saccharum officinarum L. & cana amarela & 0 & 1 & 0 & 1 & 0,01 & 1 \\
\hline & Saccharum officinarum L. & cana branca & 2 & 0 & 0 & 2 & 0,03 & 1 \\
\hline & Saccharum officinarum $\mathrm{L}$. & cana caiana & 1 & 2 & 0 & 3 & 0,04 & 1 \\
\hline & Saccharum officinarum $\mathrm{L}$. & cana cinza & 0 & 1 & 0 & 1 & 0,01 & 1 \\
\hline & Saccharum officinarum L. & cana java & 1 & 0 & 0 & 1 & 0,01 & 1 \\
\hline & Saccharum officinarum L. & cana pau & 0 & 4 & 3 & 7 & 0,10 & 1 \\
\hline & Saccharum officinarum $\mathrm{L}$. & cana preta (mole) & 4 & 7 & 4 & 15 & 0,21 & 1 \\
\hline & Saccharum officinarum $\mathrm{L}$. & cana rendosa & 0 & 1 & 0 & 1 & 0,01 & 1 \\
\hline & Saccharum officinarum $\mathrm{L}$. & cana rosa & 0 & 0 & 1 & 1 & 0,01 & 1 \\
\hline & Saccharum officinarum $\mathrm{L}$. & cana vermelha & 1 & 1 & 0 & 2 & 0,03 & 1 \\
\hline & Coix lacryma-jobi L. & capiá & 2 & 4 & 1 & 7 & 0,10 & 5 \\
\hline & Cymbopogon citratus (DC.) Stapf & capim cidró (cidreira) & 7 & 4 & 5 & 16 & 0,23 & 1,2 \\
\hline & sem identificação & bambu & 6 & 7 & 2 & 15 & 0,21 & 5 \\
\hline & sem identificação & bambu do reino & 1 & 0 & 0 & 1 & 0,01 & 5 \\
\hline & sem identificação & bambu preto & 1 & 0 & 0 & 1 & 0,01 & 5 \\
\hline
\end{tabular}


Continuação: Etnovariedades parcial ou totalmente identificadas presentes nos jardins quintal das comunidades quilombolas de Sapatu, São Pedro e Pedro Cubas, município de Eldorado Paulista, SP. (SAP: Sapatu; PEC: Pedro Cubas; SP: São Pedro; Oc: ocorrência; $\mathbf{n}$ : número de unidades domésticas visitadas por comunidade; Fr.: frequencia relativa ( $\mathrm{n}=71)$; Uso: 1 = alimentação; 2 = medicinal; $\mathbf{3}$ = ornamental; $\mathbf{4}$ = simbólico-afetiva; $\mathbf{5}$ = outros)

\begin{tabular}{|c|c|c|c|c|c|c|c|c|}
\hline família & espécie biológica & denominação local & $\begin{array}{c}\text { SAP } \\
(n=30)\end{array}$ & $\begin{array}{c}\text { PEC } \\
(\mathrm{n}=27)\end{array}$ & $\begin{array}{c}\mathbf{S P} \\
(\mathrm{n}=14)\end{array}$ & $\begin{array}{c}\text { total } \\
(\mathrm{n}=71)\end{array}$ & & \\
\hline & & & Oc & Oc & Oc & Oc & Fr. & Uso \\
\hline \multicolumn{9}{|c|}{ Portulacaceae } \\
\hline & Portulaca grandiflora Hook. & nove horas, flor de maio & 2 & 0 & 2 & 4 & 0,06 & 3 \\
\hline & Portulaca oleracea L. & $\begin{array}{c}\text { onze horas } \\
\text { sete sangrias, estanca }\end{array}$ & 5 & 0 & 4 & 9 & 0,13 & 3 \\
\hline & Portulacaria sp. & sangue & 0 & 0 & 3 & 3 & 0,04 & 2 \\
\hline \multicolumn{9}{|c|}{ Pteridaceae } \\
\hline & sem identificação & samambaia & 10 & 2 & 4 & 16 & 0,23 & 3 \\
\hline \multicolumn{9}{|c|}{ Rhamnaceae } \\
\hline & Hovenia dulcis Thumb. & uva chinesa, uva japonesa & 1 & 3 & 0 & 4 & 0,06 & 1 \\
\hline \multicolumn{9}{|c|}{ Rosaceae } \\
\hline & Eriobotrya japonica (Thunb.) Lindl. & $\begin{array}{c}\text { ameixa (nêspera) } \\
\text { amorinha (moranguinho }\end{array}$ & 10 & 3 & 5 & 18 & 0,25 & 1 \\
\hline & Rubos rosifolius J.E. Sm. & silvestre) & 1 & 0 & 0 & 1 & 0,01 & 1 \\
\hline & Malus $x$ cutivar & macieira & 1 & 0 & 0 & 1 & 0,01 & 1 \\
\hline & Fragaria vesca L. & morango & 0 & 0 & 1 & 1 & 0,01 & 1 \\
\hline & Rosa sp. & rosa & 27 & 5 & 18 & 50 & 0,70 & 3 \\
\hline & Rosa sp. & rosa mini & 2 & 0 & 1 & 3 & 0,04 & 3 \\
\hline
\end{tabular}


Continuação: Etnovariedades parcial ou totalmente identificadas presentes nos jardins quintal das comunidades quilombolas de Sapatu, São Pedro e Pedro Cubas, município de Eldorado Paulista, SP. (SAP: Sapatu; PEC: Pedro Cubas; SP: São Pedro; Oc: ocorrência; $\mathbf{n}$ : número de unidades domésticas visitadas por comunidade; Fr.: frequencia relativa ( $\mathrm{n}=71)$; Uso: 1 = alimentação; 2 = medicinal; $\mathbf{3}$ = ornamental; $\mathbf{4}$ = simbólico-afetiva; $\mathbf{5}$ = outros)

\begin{tabular}{|c|c|c|c|c|c|c|}
\hline família & espécie biológica & denominação local & $\begin{array}{c}\text { SAP } \\
(n=30)\end{array}$ & $\begin{array}{c}\text { PEC } \\
(\mathrm{n}=27)\end{array}$ & $\begin{array}{c}\mathbf{S P} \\
(\mathrm{n}=14)\end{array}$ & $\begin{array}{c}\text { total } \\
(\mathrm{n}=71)\end{array}$ \\
\hline
\end{tabular}

\section{Rubiaceae}

Coffea arabica L.

Coffea arabica L.

Genipa americana L.

Bathysa cf meridionalis L.B. Sm. \& Downs

Gardenia jasminoides J. Ellis Ixora cf coccinea L.

\section{Rutaceae}

Ruta graveolens L.
Citrus medica $\mathrm{L}$.

Citrus sp.

Citrus sinensis (L.) Osbeck

Citrus aurantium $\mathrm{L}$.

Citrus sinensis (L.) Osbeck Citrus sp.

Citrus reticulata Blanco

Citrus reticulata Blanco

Citrus sinensis (L.) Osbeck

$\begin{array}{cccccc}\text { Oc } & \text { Oc } & \text { Oc } & \text { Oc } & \text { Fr. } & \text { Uso } \\ 15 & 13 & 8 & 36 & 0,51 & 1 \\ 0 & 0 & 2 & 2 & 0,03 & 1 \\ 1 & 0 & 0 & 1 & 0,01 & 1 \\ 0 & 1 & 0 & 1 & 0,01 & 5 \\ 1 & 0 & 0 & 1 & 0,01 & 3 \\ 0 & 0 & 1 & 1 & 0,01 & 3\end{array}$

café
café burbon
genipapo
maria mole
não denominada
não denominada
arruda
cidra

laranja

laranja baiana, bahia,

grande

laranja china

laranja lima

laranja lima biguda

laranja mexerica morgot

laranja mexirica

laranja pêra

$\begin{array}{cccccc}5 & 1 & 3 & 9 & 0,13 & 4 \\ 1 & 0 & 1 & 2 & 0,03 & 1 \\ 9 & 0 & 3 & 12 & 0,17 & 1 \\ 3 & 4 & 6 & 13 & 0,18 & 1 \\ 7 & 2 & 1 & 10 & 0,14 & 1 \\ 3 & 4 & 2 & 9 & 0,13 & 1 \\ 1 & 1 & 0 & 2 & 0,03 & 1 \\ 1 & 0 & 0 & 1 & 0,01 & 1 \\ 14 & 11 & 10 & 35 & 0,49 & 1 \\ 2 & 0 & 0 & 2 & 0,03 & 1\end{array}$


Continuação: Etnovariedades parcial ou totalmente identificadas presentes nos jardins quintal das comunidades quilombolas de Sapatu, São Pedro e Pedro Cubas, município de Eldorado Paulista, SP. (SAP: Sapatu; PEC: Pedro Cubas; SP: São Pedro; Oc: ocorrência; $\mathbf{n}$ : número de unidades domésticas visitadas por comunidade; Fr.: frequencia relativa ( $\mathrm{n}=71)$; Uso: 1 = alimentação; 2 = medicinal; $\mathbf{3}$ = ornamental; $\mathbf{4}$ = simbólico-afetiva; $\mathbf{5}$ = outros)

\begin{tabular}{|c|c|c|c|c|c|c|}
\hline família & espécie biológica & denominação local & $\begin{array}{c}\text { SAP } \\
(n=30)\end{array}$ & $\begin{array}{c}\text { PEC } \\
(n=27)\end{array}$ & $\begin{array}{c}\text { SP } \\
(n=14)\end{array}$ & $\begin{array}{l}\text { total } \\
(n=71)\end{array}$ \\
\hline
\end{tabular}

\section{Rutaceae}

Citrus sinensis (L.) Osbeck

Citrus reticulata Blanco

Citrus aurantifolia (Christm.) Swingle

Citrus limonia (L.) Osbeck

\section{Sapindaceae}

Paullinia cupana Kunth

Litchi chinensis Sonn.

Cupania oblongifolia Mart.

\section{Solanaceae}

Solanum capsicoides All.
Nicotiana tabacum L.
Solanum gilo Raddi
Solanum paniculatum L.

Solanum cf brusquense L.B. Sm. \& Downs

Capsicum sp.

\section{Oc Oc Oc Oc $\quad$ Fr. Uso}

$\begin{array}{ccccccc}\text { laranja pêra } & 2 & 0 & 0 & 2 & 0,03 & 1 \\ \text { laranja poncã } & 16 & 7 & 4 & 27 & 0,38 & 1 \\ \text { limão branco } & 12 & 8 & 3 & 23 & 0,32 & 1 \\ \text { ão vermelho, galego } & 19 & 17 & 8 & 44 & 0,62 & 1,4\end{array}$

$\begin{array}{cllllll}\text { guaraná } & 0 & 5 & 2 & 7 & 0,10 & 1 \\ \text { lichia } & 0 & 0 & 1 & 1 & 0,01 & 1 \\ \text { papa guela } & 0 & 1 & 0 & 1 & 0,01 & 5\end{array}$

\begin{tabular}{ccccccc} 
cavalinha & 0 & 0 & 1 & 1 & 0,01 & 2 \\
fumo bravo & 7 & 4 & 2 & 13 & 0,18 & 2,5 \\
jiló & 1 & 4 & 0 & 5 & 0,07 & 1 \\
jurubeba & 0 & 0 & 1 & 1 & 0,01 & 2 \\
maná & 1 & 3 & 0 & 4 & 0,06 & 1 \\
não denominada & 1 & 0 & 0 & 1 & 0,01 & 1 \\
\hline
\end{tabular}


Continuação: Etnovariedades parcial ou totalmente identificadas presentes nos jardins quintal das comunidades quilombolas de Sapatu, São Pedro e Pedro Cubas, município de Eldorado Paulista, SP. (SAP: Sapatu; PEC: Pedro Cubas; SP: São Pedro; Oc: ocorrência; $\mathbf{n}$ : número de unidades domésticas visitadas por comunidade; Fr.: frequencia relativa ( $\mathrm{n}=71)$; Uso: 1 = alimentação; 2 = medicinal; $\mathbf{3}$ = ornamental; $\mathbf{4}$ = simbólico-afetiva; $\mathbf{5}$ = outros)

\begin{tabular}{|c|c|c|c|c|c|c|}
\hline família & espécie biológica & denominação local & $\begin{array}{c}\text { SAP } \\
(n=30)\end{array}$ & $\begin{array}{c}\text { PEC } \\
(\mathrm{n}=27)\end{array}$ & $\begin{array}{c}\mathbf{S P} \\
(\mathrm{n}=14)\end{array}$ & $\begin{array}{c}\text { total } \\
(\mathrm{n}=71)\end{array}$ \\
\hline
\end{tabular}

\title{
Solanaceae
}

Capsicum sp.

Capsicum frutescens Rodsch.

Capsicum sp

Capsicum sp

Capsicum sp

Capsicum flexuosum Sendtn Capsicum sp

Capsicum sp

Capsicum annuum L.

Capsicum baccatum L.

Lycopersicum esculentum Mill.

Lycopersicum sp. Mill sem identificação

Oc Oc Oc Oc \\ Oc Oc Oc Oc}

Fr. Uso

pimenta
pimenta cambarí
(malagueta)
pimenta de cheiro
pimenta dedo de moça
pimenta esporinha de galo
pimenta moranguinho
pimenta peito de moça
pimenta redondinha
(farofinha)
pimentão
pimenteira
tomate
tomatinho
bracuinha (gracuinha)

$\begin{array}{llcccc}7 & 2 & 2 & 11 & 0,15 & 1 \\ 3 & 5 & 2 & 10 & 0,14 & 1 \\ 0 & 1 & 0 & 1 & 0,01 & 1 \\ 2 & 0 & 0 & 2 & 0,03 & 1 \\ 0 & 1 & 0 & 1 & 0,01 & 1 \\ 0 & 1 & 0 & 1 & 0,01 & 1 \\ 0 & 1 & 1 & 2 & 0,03 & 1 \\ 4 & 3 & 2 & 9 & 0,13 & 1 \\ 3 & 0 & 2 & 5 & 0,07 & 1 \\ 1 & 0 & 0 & 1 & 0,01 & 1 \\ 5 & 3 & 0 & 8 & 0,11 & 1 \\ 2 & 2 & 3 & 7 & 0,10 & 1 \\ 2 & 1 & 0 & 3 & 0,04 & 2\end{array}$

\section{Sterculiaceae}

Theobroma cacao L.

\begin{abstract}
cacau
\end{abstract}


Continuação: Etnovariedades parcial ou totalmente identificadas presentes nos jardins quintal das comunidades quilombolas de Sapatu, São Pedro e Pedro Cubas, município de Eldorado Paulista, SP. (SAP: Sapatu; PEC: Pedro Cubas; SP: São Pedro; Oc: ocorrência; $\mathbf{n}$ : número de unidades domésticas visitadas por comunidade; Fr.: frequencia relativa ( $\mathrm{n}=71)$; Uso: 1 = alimentação; 2 = medicinal; $\mathbf{3}$ = ornamental; $\mathbf{4}$ = simbólico-afetiva; $\mathbf{5}$ = outros)

\begin{tabular}{|c|c|c|c|c|c|c|c|}
\hline espécie biológica & denominação local & $\begin{array}{c}\text { SAP } \\
(\mathrm{n}=30)\end{array}$ & $\begin{array}{c}\text { PEC } \\
(\mathrm{n}=27)\end{array}$ & $\begin{array}{c}\mathbf{S P} \\
(n=14)\end{array}$ & $\begin{array}{c}\text { total } \\
(\mathrm{n}=71)\end{array}$ & & \\
\hline & & Oc & Oc & Oc & Oc & Fr. & Uso \\
\hline \multicolumn{8}{|l|}{ Turneraceae } \\
\hline Turnera subulata Lur. & flor japonesa & 3 & 0 & 0 & 3 & 0,04 & 3 \\
\hline \multicolumn{8}{|l|}{ Ulmaceae } \\
\hline Trema micrantha (L.) Blume & não denominada & 1 & 0 & 0 & 1 & 0,01 & 3,5 \\
\hline \multicolumn{8}{|l|}{ Urticaceae } \\
\hline Pilea microphylla (L.) Liebm. & brilhantina & 2 & 0 & 0 & 2 & 0,03 & 3 \\
\hline \multicolumn{8}{|l|}{ Verbenaceae } \\
\hline Verbena officinalis L. & jarbão & 2 & 4 & 4 & 10 & 0,14 & 2 \\
\hline Duranta repens L. & pingo de ouro & 5 & 1 & 0 & 6 & 0,08 & 3 \\
\hline \multicolumn{8}{|l|}{ Zingiberaceae } \\
\hline Curcuma longa L. & açafrão & 0 & 7 & 1 & 8 & 0,11 & 1 \\
\hline Costus spiralis (Jacq.) Roscoe & cana do brejo & 1 & 1 & 1 & 3 & 0,04 & 3 \\
\hline Renealmia petasites Gagnep & flor de bananeira & 0 & 1 & 0 & 1 & 0,01 & 3 \\
\hline Zingiber officinale Roscoe & gengibre & 2 & 2 & 2 & 6 & 0,08 & 1 \\
\hline sem identificação & incenso & 0 & 0 & 1 & 1 & 0,01 & 3 \\
\hline
\end{tabular}




\section{Apêndice G}

Caracterização das espécies de plantas medicinais cultivadas nos quilombos de Sapatu, São Pedro e Pedro Cubas, Município de Eldorado Paulista, São Paulo (nome vulgar, espécie biológica, parte utilizada e indicações etnobotânicas)

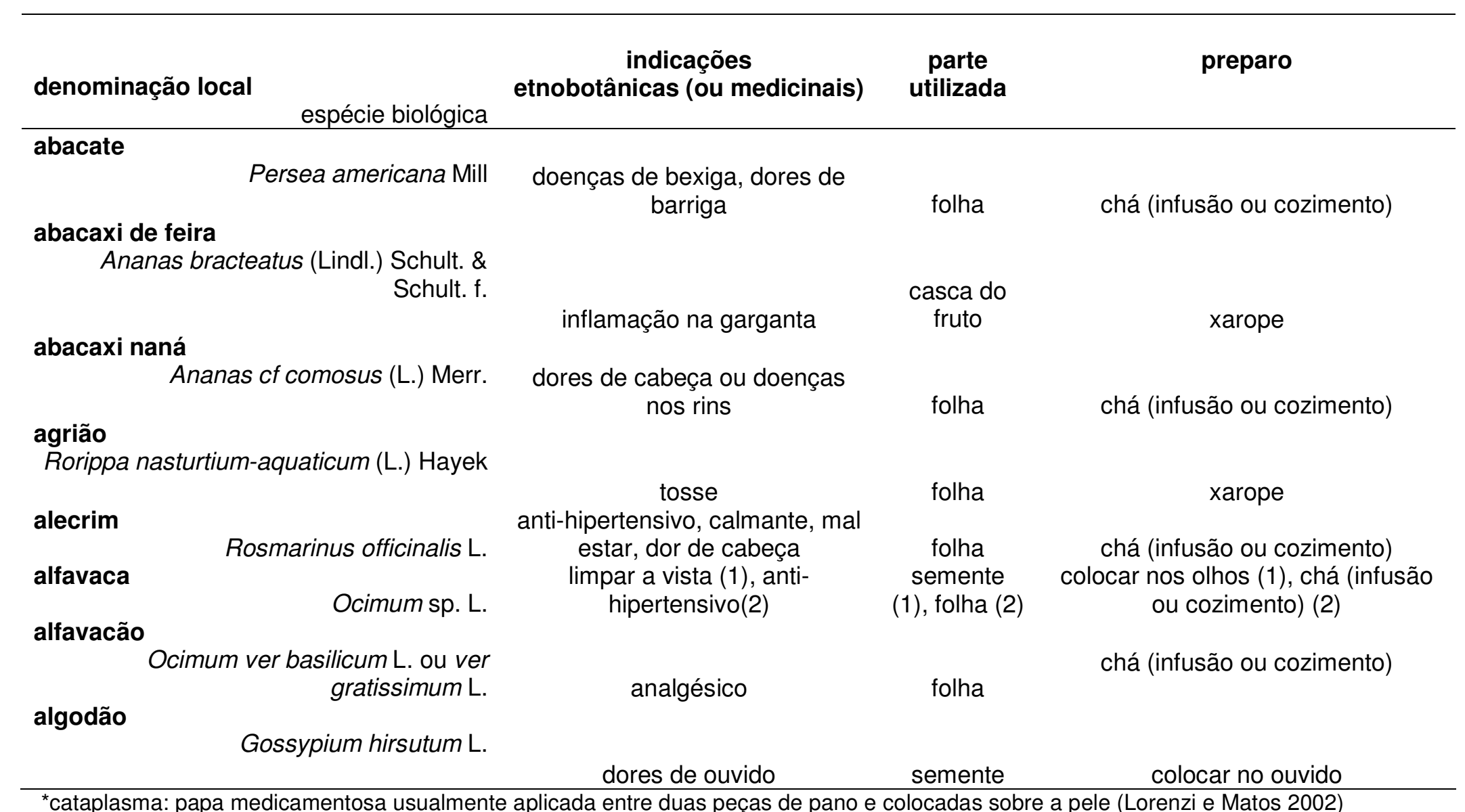


Continuação: Caracterização das espécies de plantas medicinais cultivadas nos quilombos de Sapatu, São Pedro e Pedro Cubas, Município de Eldorado Paulista, São Paulo (nome vulgar, espécie biológica, parte utilizada e indicações etnobotânicas)

\begin{tabular}{|c|c|c|c|c|}
\hline denominação local & espécie biológica & $\begin{array}{c}\text { indicações } \\
\text { etnobotânicas (ou medicinais) }\end{array}$ & $\begin{array}{c}\text { parte } \\
\text { utilizada }\end{array}$ & preparo \\
\hline \multicolumn{5}{|c|}{ Eriobotrya japonica (Thunb.) Lindl. } \\
\hline & & anti-hipertensivo & folha & chá (infusão ou cozimento) \\
\hline \multicolumn{5}{|l|}{ amora } \\
\hline \multicolumn{5}{|c|}{ Morus nigra L. } \\
\hline & & anti-hipertensivo & follha & chá (infusão ou cozimento) \\
\hline \multicolumn{2}{|l|}{ ampicilina } & & & cozimento (1), infusão ou \\
\hline \multicolumn{2}{|c|}{ Alternanthera brasiliana (L.) Kuntze } & $\begin{array}{l}\text { antiinflamatório, dor de garganta } \\
\text { (1), cicatrizante e anti-séptico (2) }\end{array}$ & folha & cataplasma* (2) \\
\hline \multicolumn{5}{|c|}{ 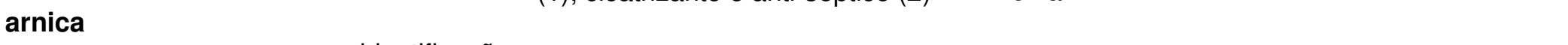 } \\
\hline \multicolumn{5}{|c|}{ sem identificação } \\
\hline & & analgésico & folha & chá (infusão ou cozimento) \\
\hline \multicolumn{5}{|l|}{ aroeira } \\
\hline & sem identificação & & & \\
\hline & & sarna & folha & cozimento e banho \\
\hline \multicolumn{5}{|l|}{ arruda } \\
\hline & Ruta graveolens L. & $\begin{array}{c}\text { doenças no fígado (1) ou dores } \\
\text { de barriga (2) }\end{array}$ & folha & $\begin{array}{c}\text { chá (infusão ou cozimento) puro (1) } \\
\text { ou com mel (2) }\end{array}$ \\
\hline \multicolumn{5}{|l|}{ assapeixe, sapeixe } \\
\hline & sem identificação & & & \\
\hline \multirow{3}{*}{\multicolumn{2}{|c|}{$\begin{array}{l}\text { atroveran, novalgina, dipirona } \\
\text { sem identificação }\end{array}$}} & cicatrizante e anti-séptico, sarna & raiz & $\begin{array}{c}\text { cozimento e banho } \\
\text { chá (infusão ou cozimento) ou }\end{array}$ \\
\hline & & & & cha (IIIUSa ou cozimitemo ou \\
\hline & & gripe & folha & \\
\hline \multicolumn{5}{|l|}{ azedinha } \\
\hline & sem identificação & & & \\
\hline & & dores de barriga & folha & chá (infusão ou cozimento) \\
\hline
\end{tabular}


Continuação: caracterização das espécies de plantas medicinais cultivadas nos quilombos de Sapatu, São Pedro e Pedro Cubas, Município de Eldorado Paulista, São Paulo (nome vulgar, espécie biológica, parte utilizada e indicações etnobotânicas)

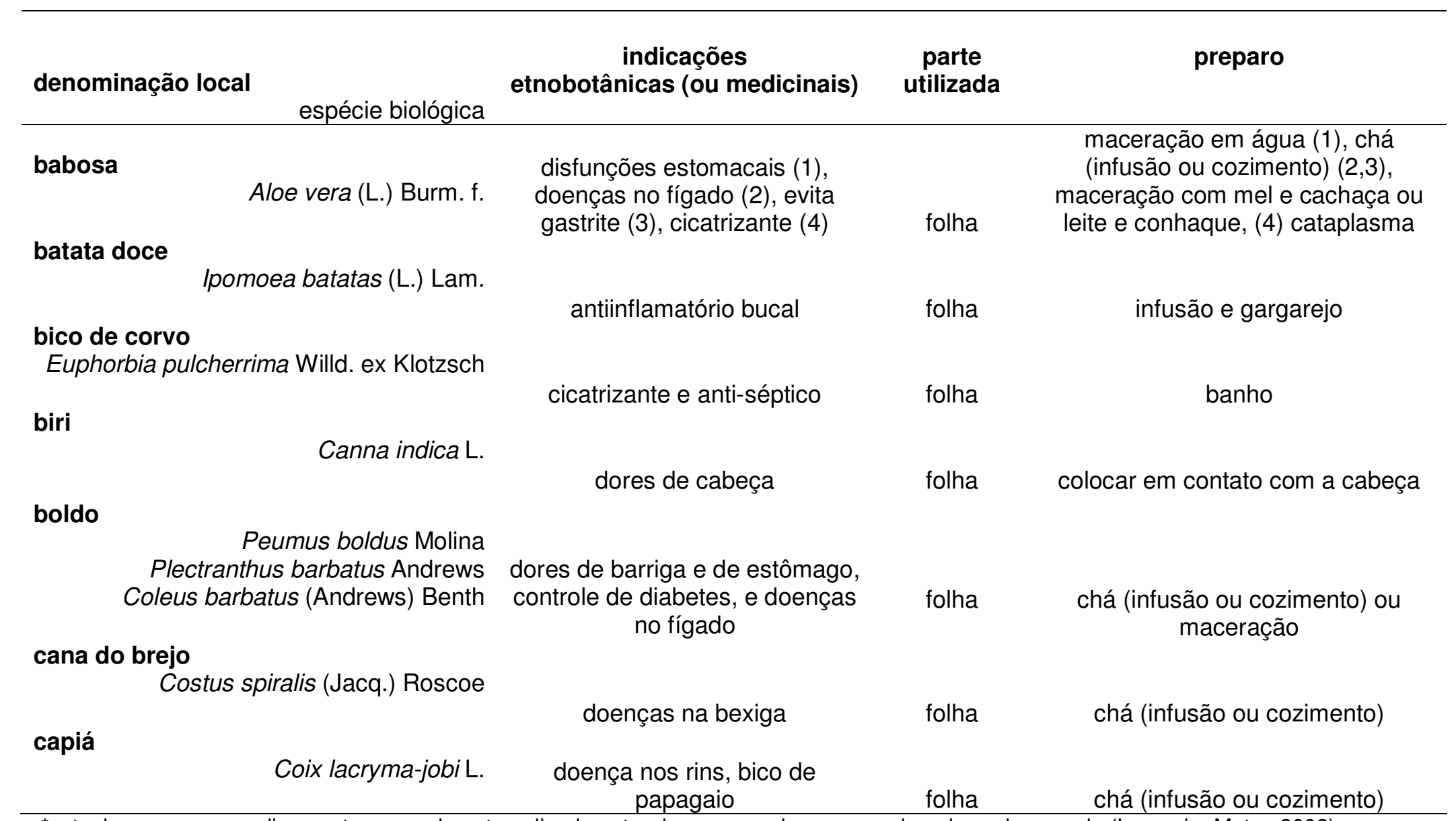

*cataplasma: papa medicamentosa usualmente aplicada entre duas peças de pano e colocadas sobre a pele (Lorenzi e Matos 2002) 
Continuação: caracterização das espécies de plantas medicinais cultivadas nos quilombos de Sapatu, São Pedro e Pedro Cubas, Município de Eldorado Paulista, São Paulo (nome vulgar, espécie biológica, parte utilizada e indicações etnobotânicas)

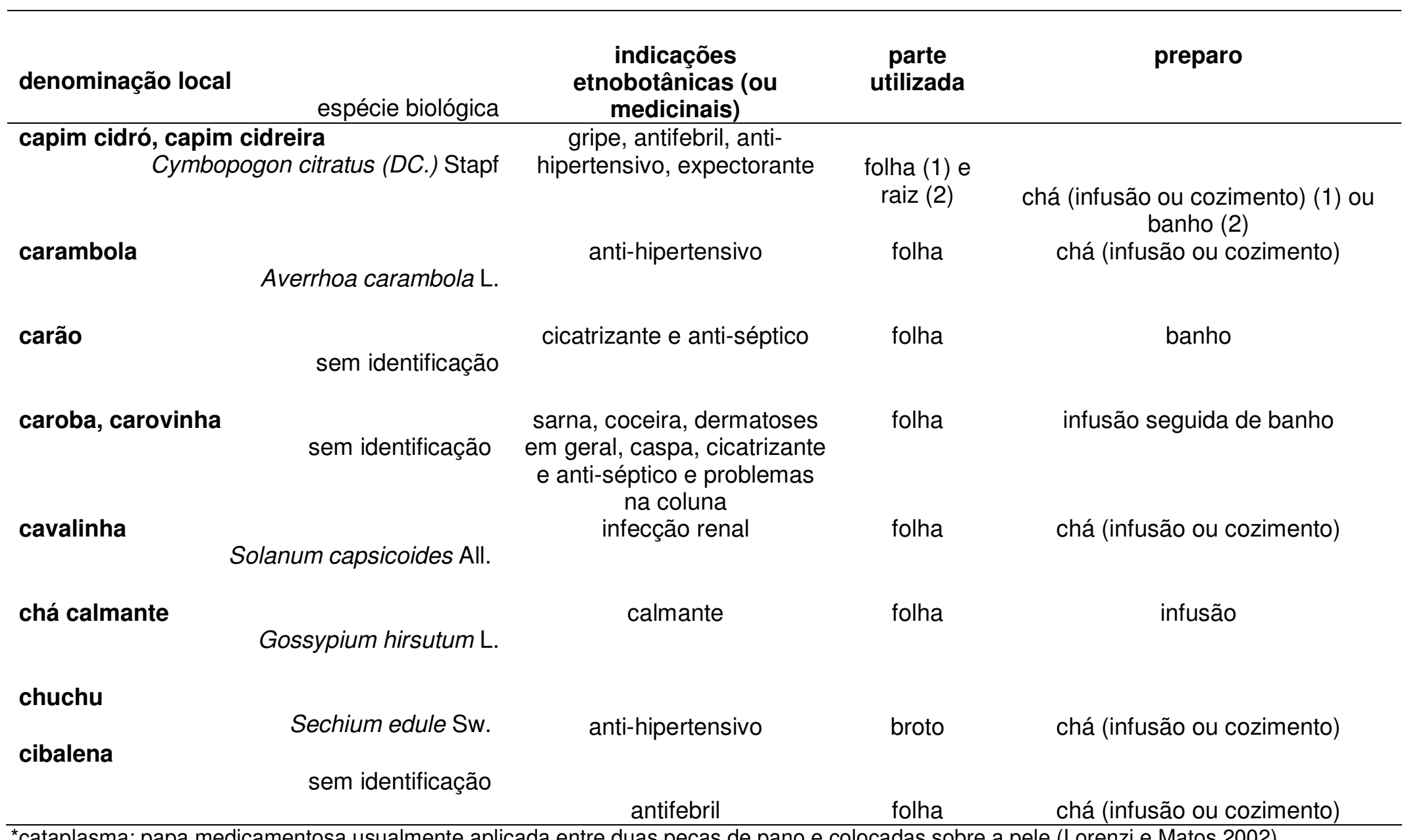


Continuação: caracterização das espécies de plantas medicinais cultivadas nos quilombos de Sapatu, São Pedro e Pedro Cubas, Município de Eldorado Paulista, São Paulo (nome vulgar, espécie biológica, parte utilizada e indicações etnobotânicas)

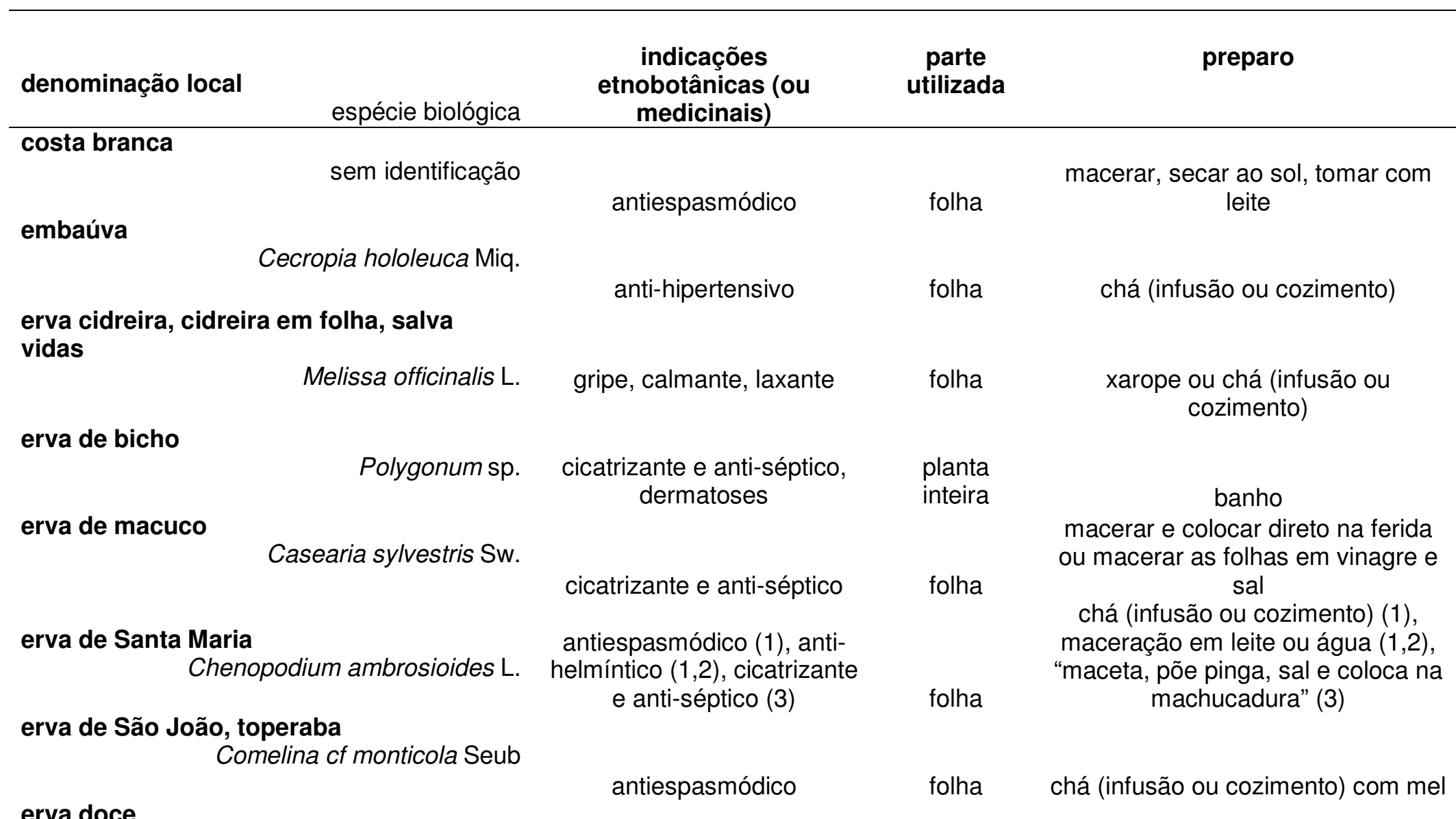

Pimpinella anisum L.

gripe

folha

chá (infusão ou cozimento)

${ }^{*}$ cataplasma: papa medicamentosa usualmente aplicada entre duas peças de pano e colocadas sobre a pele (Lorenzi e Matos 2002) 
Continuação: caracterização das espécies de plantas medicinais cultivadas nos quilombos de Sapatu, São Pedro e Pedro Cubas, Município de Eldorado Paulista, São Paulo (nome vulgar, espécie biológica, parte utilizada e indicações etnobotânicas)

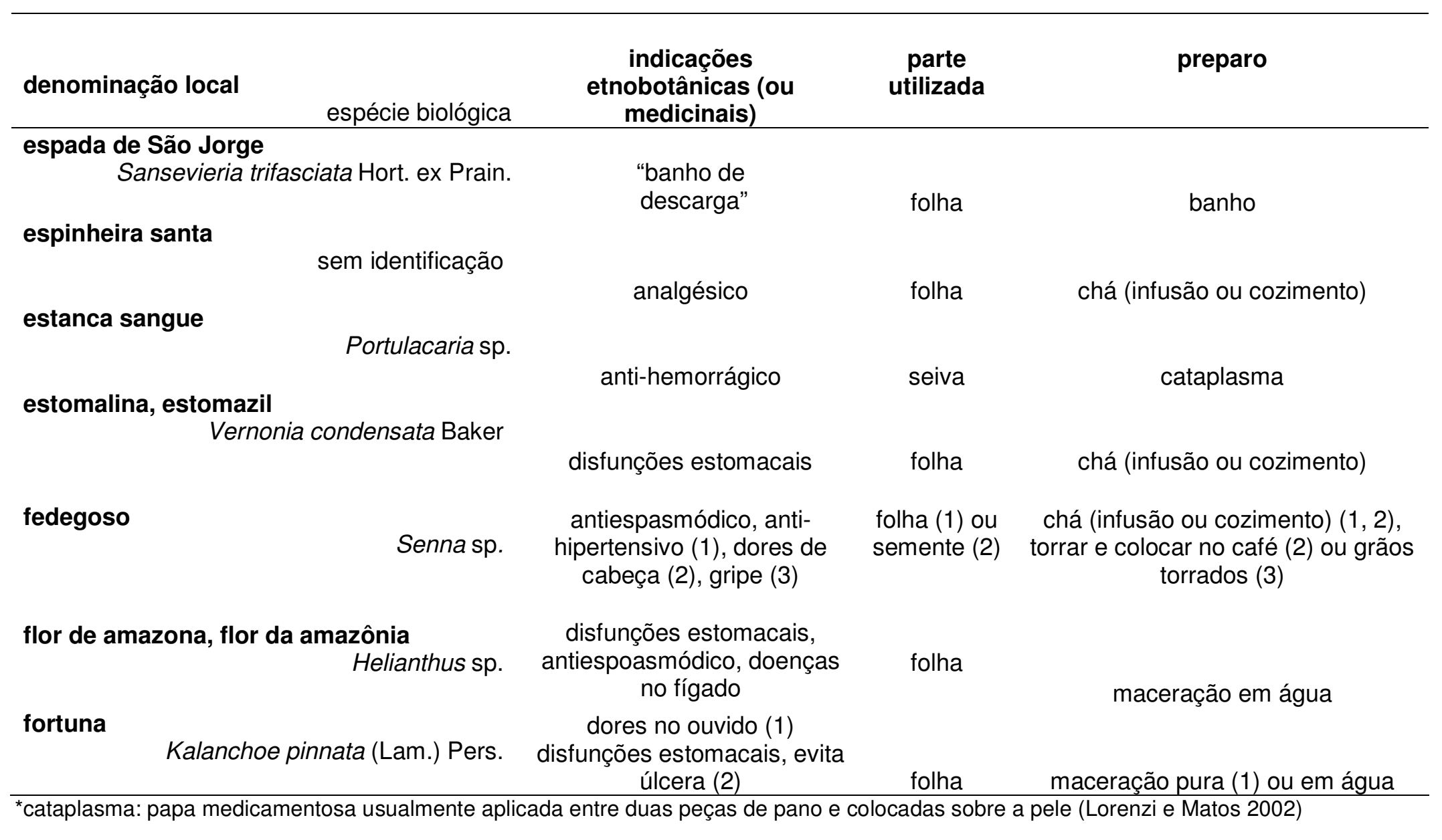


Continuação: caracterização das espécies de plantas medicinais cultivadas nos quilombos de Sapatu, São Pedro e Pedro Cubas, Município de Eldorado Paulista, São Paulo (nome vulgar, espécie biológica, parte utilizada e indicações etnobotânicas)

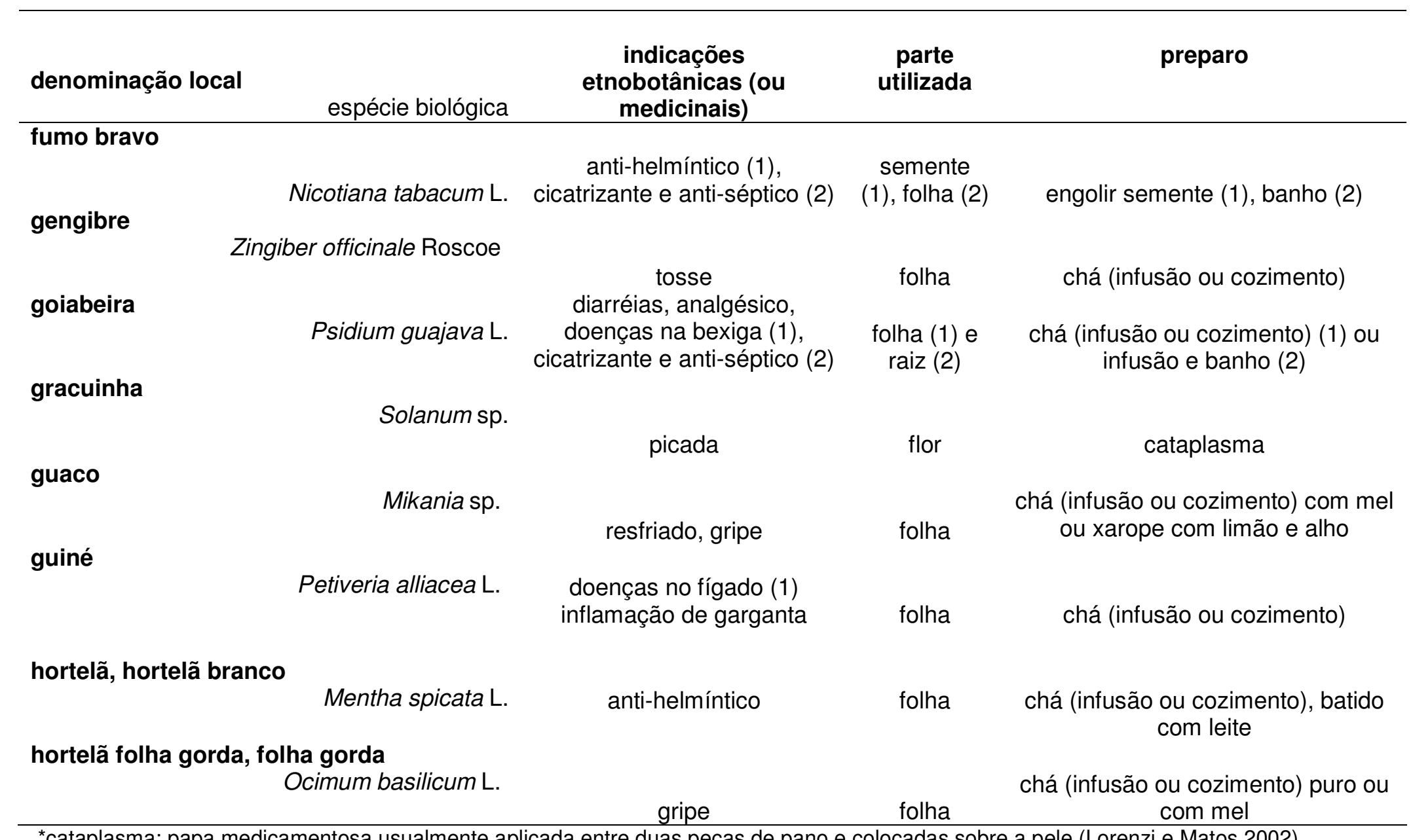


Continuação: caracterização das espécies de plantas medicinais cultivadas nos quilombos de Sapatu, São Pedro e Pedro Cubas, Município de Eldorado Paulista, São Paulo (nome vulgar, espécie biológica, parte utilizada e indicações etnobotânicas)

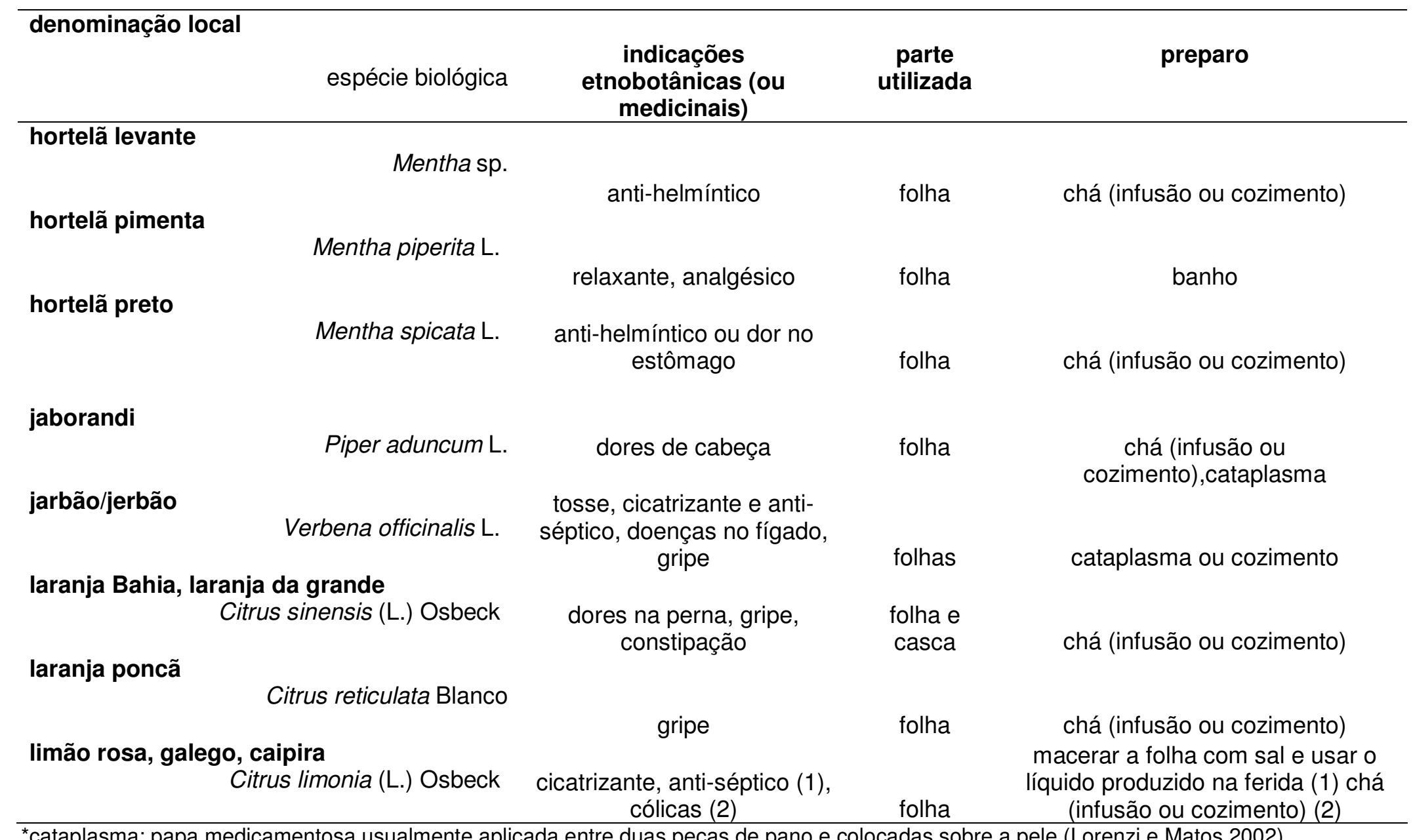


Continuação: caracterização das espécies de plantas medicinais cultivadas nos quilombos de Sapatu, São Pedro e Pedro Cubas, Município de Eldorado Paulista, São Paulo (nome vulgar, espécie biológica, parte utilizada e indicações etnobotânicas)

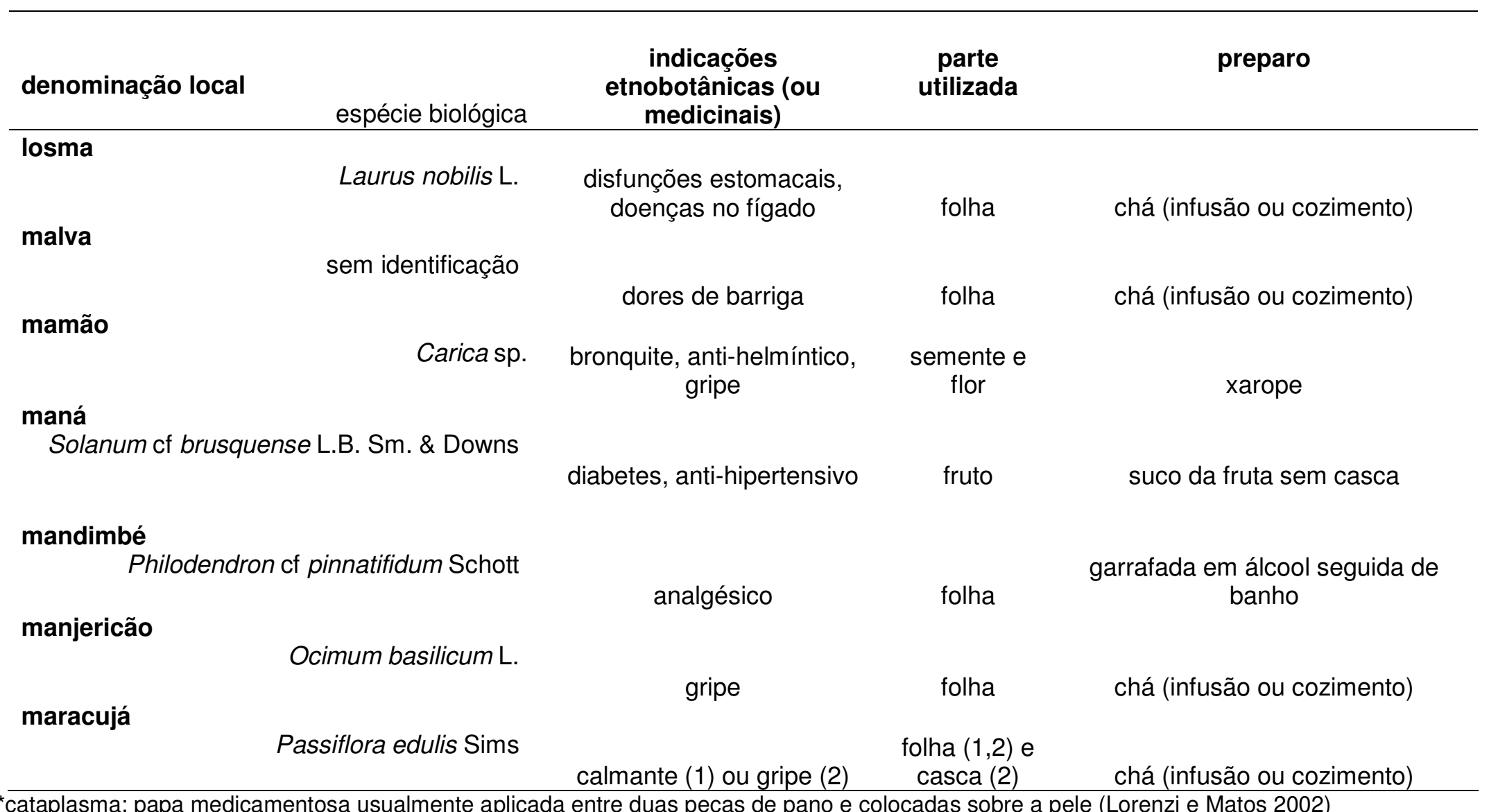


Continuação: caracterização das espécies de plantas medicinais cultivadas nos quilombos de Sapatu, São Pedro e Pedro Cubas, Município de Eldorado Paulista, São Paulo (nome vulgar, espécie biológica, parte utilizada e indicações etnobotânicas)

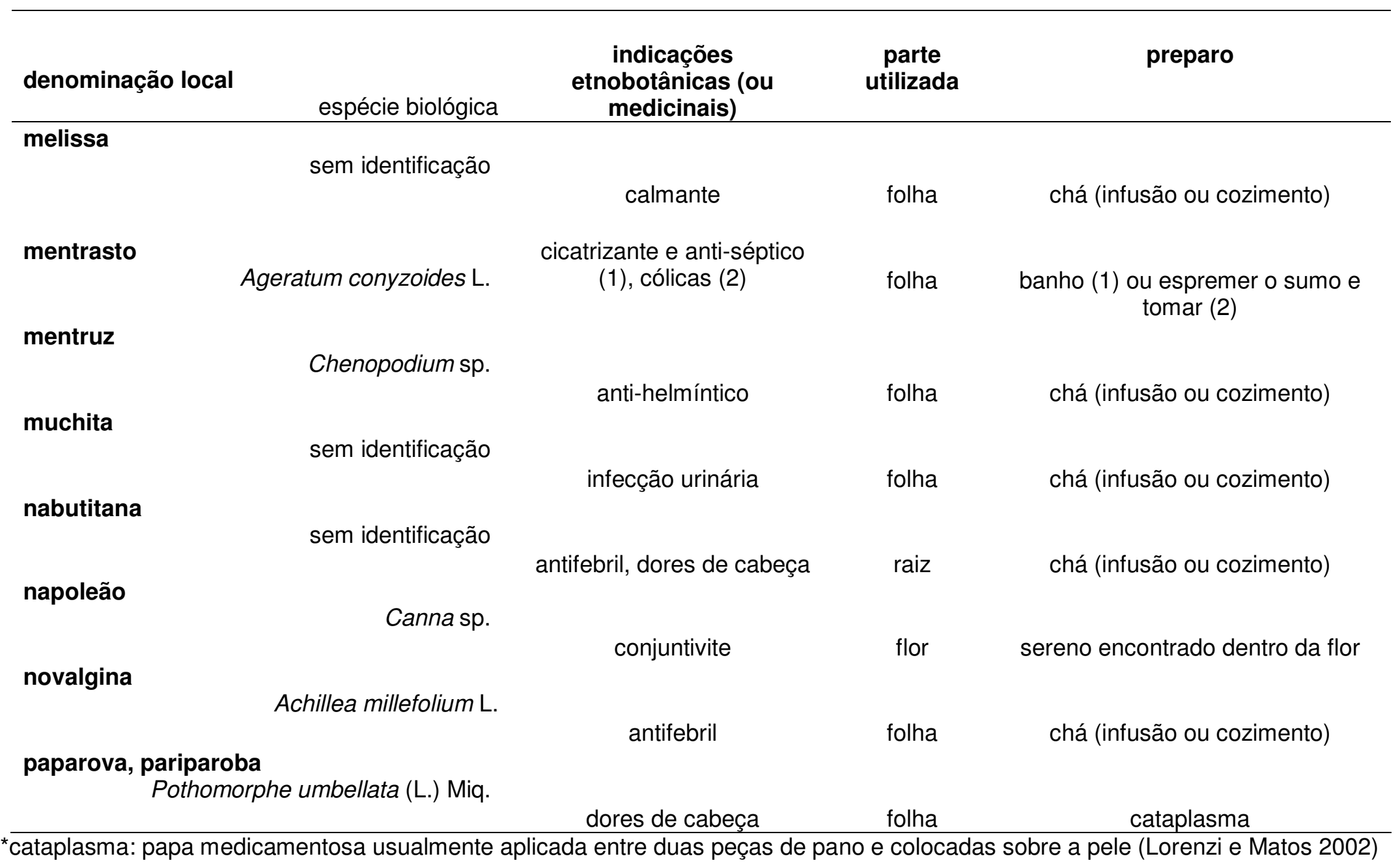


Continuação: caracterização das espécies de plantas medicinais cultivadas nos quilombos de Sapatu, São Pedro e Pedro Cubas, Município de Eldorado Paulista, São Paulo (nome vulgar, espécie biológica, parte utilizada e indicações etnobotânicas)

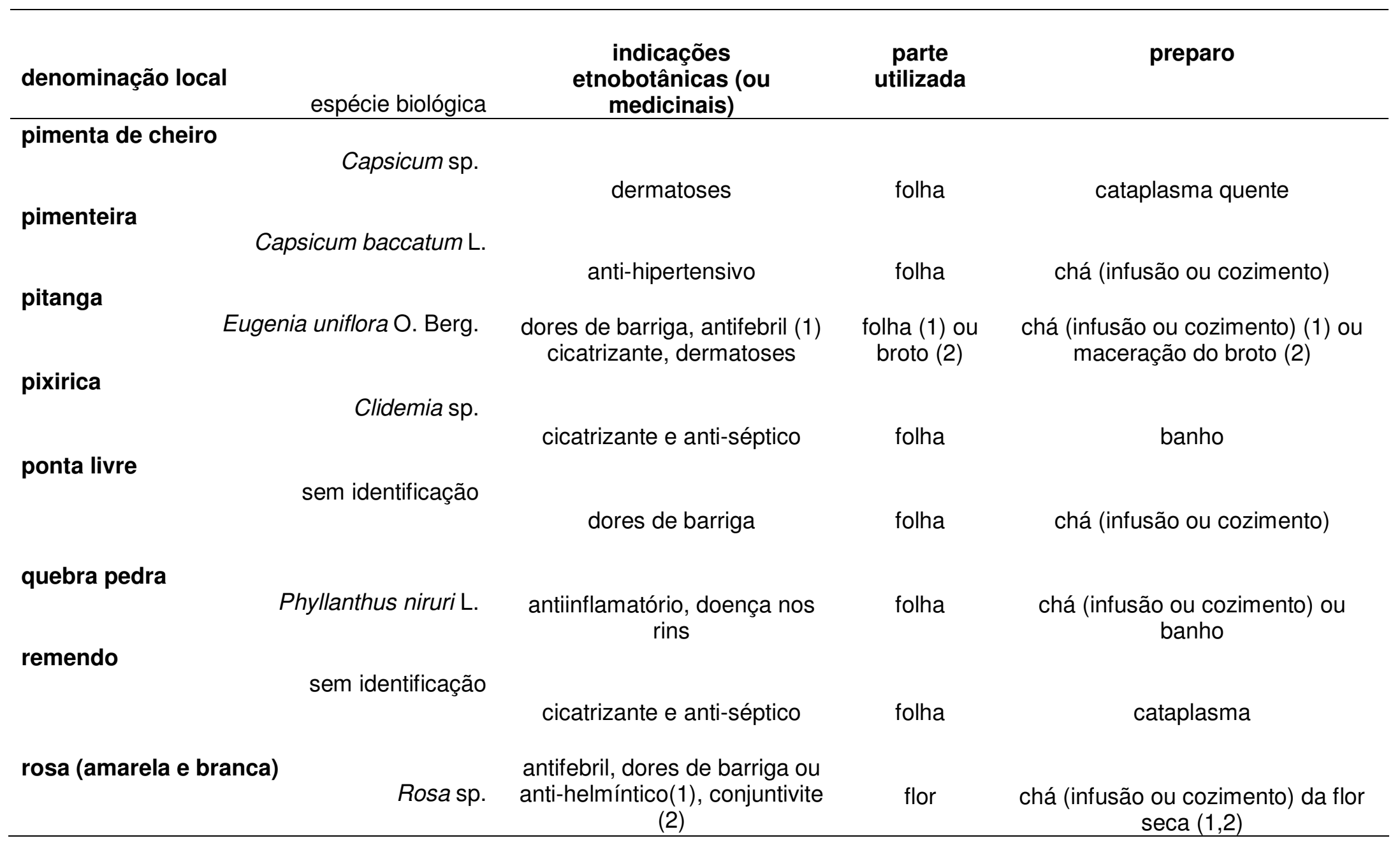


Continuação: caracterização das espécies de plantas medicinais cultivadas nos quilombos de Sapatu, São Pedro e Pedro Cubas, Município de Eldorado Paulista, São Paulo (nome vulgar, espécie biológica, parte utilizada e indicações etnobotânicas)

\begin{tabular}{|c|c|c|c|c|}
\hline denominação local & espécie biológica & $\begin{array}{c}\text { indicações } \\
\text { etnobotânicas (ou } \\
\text { medicinais) }\end{array}$ & $\begin{array}{c}\text { parte } \\
\text { utilizada }\end{array}$ & preparo \\
\hline rubim & Leonurus sp. & cicatrizante e anti-séptico & folha & maceração em água \\
\hline rueira & Schinus sp. & cicatrizante e anti-séptico & folha & banho \\
\hline sabugueira & Sambucus nigra L. & $\begin{array}{l}\text { cicatrizante e anti-séptico } \\
(1) \text {, antifebril, gripe, catapora } \\
\text { (2) }\end{array}$ & $\begin{array}{l}\text { flor (1) ou } \\
\text { folha (2) }\end{array}$ & $\begin{array}{c}\text { banho (1), chá (infusão ou } \\
\text { cozimento) (2) }\end{array}$ \\
\hline salicínio & sem identificação & cicatrizante e anti-séptico & folha & curtir no álcool \\
\hline & sem identificação & antifebril & folha & chá (infusão ou cozimento) \\
\hline sangue de Adão & sem identificação & dores no ouvido & folha & maceracão \\
\hline sangue de boi & Iresine herbstii Hook & $\begin{array}{l}\text { antiinflamatório e } \\
\text { cicatrizante }\end{array}$ & folha & infusão \\
\hline São Fidelis & sem identificação & calmante, anti-hipertensivo & folha & chá (infusão ou cozimento) \\
\hline
\end{tabular}

\footnotetext{
*cataplasma: papa medicamentosa usualmente aplicada entre duas peças de pano e colocadas sobre a pele (Lorenzi e Matos 2002)
} 
Continuação: caracterização das espécies de plantas medicinais cultivadas nos quilombos de Sapatu, São Pedro e Pedro Cubas, Município de Eldorado Paulista, São Paulo (nome vulgar, espécie biológica, parte utilizada e indicações etnobotânicas)

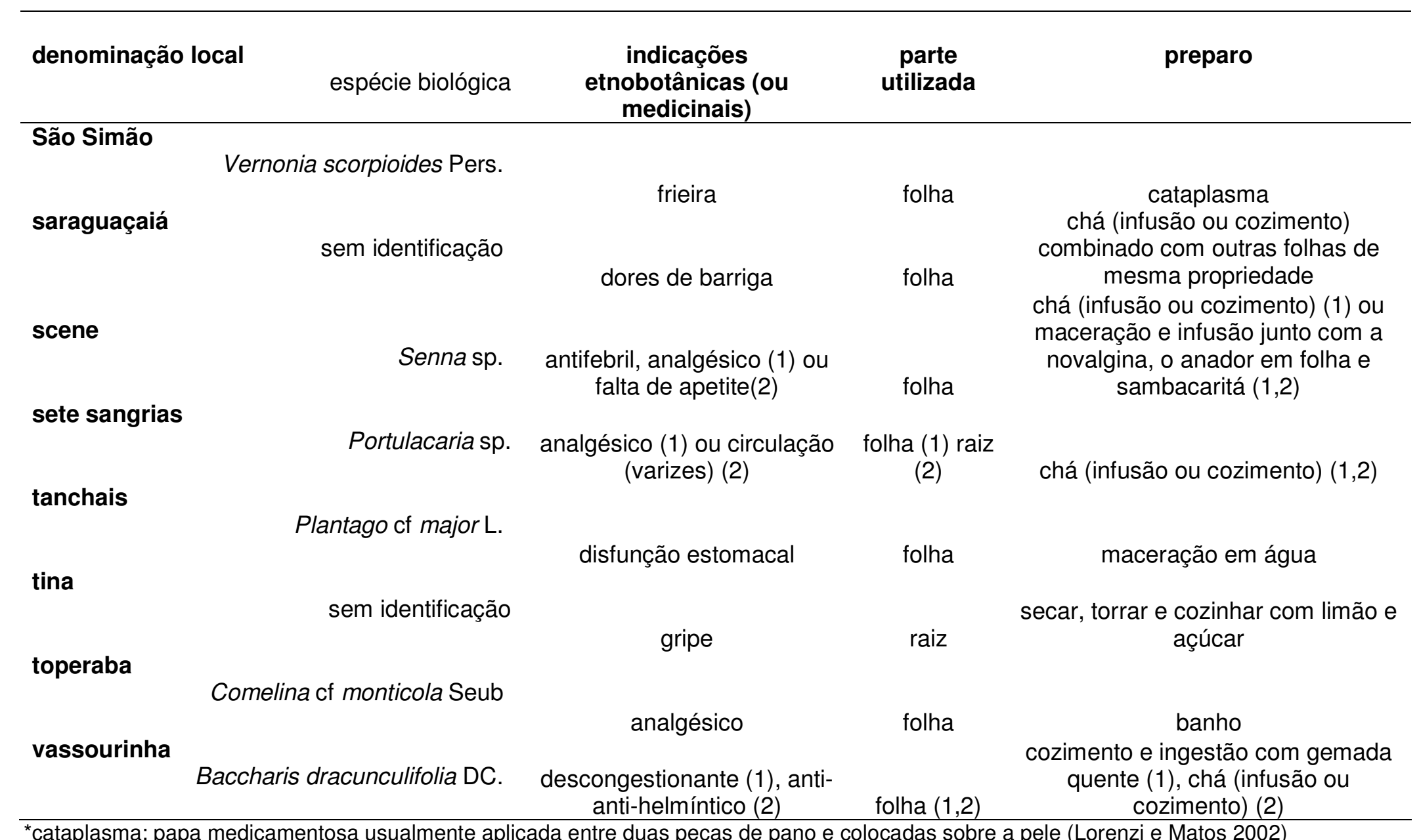

